\title{
SUBSEQUENCE, PROPHECY AND CHURCH ORDER IN THE APOSTOLIC CHURCH, NEW ZEALAND
}

by

W. Luke Worsfold

\author{
A thesis \\ submitted to the Victoria University of Wellington \\ in fulfilment of the \\ requirements for the degree of \\ Doctor of Philosophy \\ in Religious Studies
}

Victoria University of Wellington 
To my father, James Evans Worsfold 


\section{ABSTRACT \\ SUBSEQUENCE, PROPHECY AND CHURCH ORDER IN THE APOSTOLIC CHURCH, NEW ZEALAND}

The Apostolic Church of New Zealand forms a distinct group within the pentecostal movement on account of its practice of "divine government." The revelation of the restoration of apostle and prophet ministry, which originally came to the founders in the UK, served to establish a denomination which espoused prophetic guidance in matters of praxis and doctrine. The purpose of this thesis has been to critique the Apostolic Church's understanding of not only the doctrine of subsequence (i.e. Spirit-baptism is logically distinct from and subsequent to salvation) but the function of the prophetic and its effect on the organisational structure and operation of the church.

A major focus of the early Apostolic churchmen was a defence of subsequence. Widespread mainstream opposition ensured pentecostals endured an isolation which served to reinforce their determination to validate the empowerment that they had experienced. As the need for polemic reduced, the emphasis shifted to promoting the gift of the Spirit as a missionary endowment.

Methodist-Holiness teaching formed the basis for the early influences on pentecostal theology and as such promoted a verifiable work of the Spirit given in response to seeking. The challenge and influence from the Latter Rain and Charismatic movements saw the bestowal of the gift without an attendant period of tarrying. While this brought a universality to the experience, it did so at the expense of depth or intensity, with a resulting weakening in the expression of prophecy. 
An assessment of the view of prophecy held by the early Apostolic churchmen shows that too high a level of inspiration was often credited to prophetic utterance. The possibility of human frailty corrupting the purposes of God was not countenanced to any great degree, with the result that flawed or outright erroneous decisions proceeded unchallenged: in this the role of the apostle was under-exercised. The combination of a high view of prophecy and a decreasing quality of utterance over time affected the level of guidance available to the movement. The operation of the apostle necessarily changed: previously concerned with outworking the "Word of the Lord," the function of the apostle became limited to that of superintendent minister.

The inability of the first and second generation Apostolics to recognise their schismatic origins perpetuated the rigid adherence to centralism, believing it to be the divine pattern. Centralised control manifested in two spheres: finance and personnel. Initially, when the movement was small, centralism was an expedient philosophy; however, its usefulness was soon outgrown. A retarding factor for the Apostolic Church has been the lack of autonomy afforded local assemblies and the ineptitude of the centralised government, which frequently mismatched men and their roles. Currently, there exists a trend towards relationship-based apostleship, utilising the concept of networks. A particular subset of this system is the church plant where a natural line of authority exists between it and the parent church. Prophecy operating in this situation confines itself to expansion, and avoids the problem, evident in previous years, of centralised revelation initiating the relocation of personnel. The Apostolic Church will survive the $21^{\text {st }}$ century by allowing greater autonomy, with the apostolic function and the prophetic voice finding expression primarily through the local assembly. 


\section{ACKNOWLEDGEMENTS}

I am grateful for the opportunity to have completed this study in a Religious Studies Department on account of the greater freedom afforded to investigate the issue, as compared to the constraints inherent in pursuing such a topic in a purely theological discipline.

This work would not have been possible without the support of many. In particular I would like to thank: The Julian Literature Trust for supplying a scholarship; Dr Mark Hutchinson for direction early in the project; Associate Professor James Veitch for his supervision; the many Apostolic Church pastors and lay people who willingly provided interviews and loaned their written resources; my wife, Renée, who read and corrected the entire work; and my mother, who kept me focussed on the end goal. Lastly, I owe a debt to my late father, who first stimulated my thinking on the topic. 


\section{CONTENTS}

Background to the Term 'Spirit-baptism'

Pentecostal Proof Texts

Subsequence

Prophecy

Apostolic Function

Purpose

Methodology

Author's Position

CHAPTER ONE

APOSTOLIC CHURCH ORIGINS

W. O. Hutchinson and the Apostolic Faith Church

D. P. Williams and the Apostolic Faith Church

Factors in the Formation of the Apostolic Church

The Secession

The Apostolic Church in New Zealand

Summary

CHAPTER TWO

SUBSEQUENCE

Opposition to Pentecostalism

Pentecostal Apologetic

Apostolic Doctrine

Premillenialism

Tarrying

Summary 
An Issue of Theology

"With" / "In" Schema

Differentiation of the Spirit of Christ from the Holy Spirit

A Related Problem

Tarrying

Latter Rain

The Charismatic Movement

The Present Position

Summary

CHAPTER FOUR

PROPHECY

The Nature of Prophecy

The Function of Prophecy

Shifts in the Practice of Prophecy

The Process of Prophecy

Summary

CHAPTER FIVE

CRITIQUE OF PROPHECY

Form of Prophecy

Content of Prophecy

Functioning of Prophecy

Weberian Analysis

Conclusion

Finance

Centralism's Other Arm

Restructuring the Movement

Maori Issues

Summary 
Specific Findings

The Way Ahead

APPENDIX

"BAPTISM IN THE SPIRIT" SURVEY

280

SOURCES CONSULTED 


\section{INTRODUCTION}

A distinguishing feature of pentecostalism is that its pneumatology predicates a post-conversion filling with the Spirit. In fact, it has been rightly observed that the pentecostal doctrine of the Holy Spirit is essentially the experience of the Spirit. ${ }^{1}$ One is not generally referred to as a Pentecostal because of a belief in, but rather an experience of, the Spirit. Given that an experience is the fundamental essence of being pentecostal it requires that an understanding of the event be achieved. In attempting a definition, however, one is immediately faced with the theological difficulty of postulating an "additional" work of God in the life of the believer. A first approach to the task may consist of examining the label and biblical material upon which this experience is posited.

\section{Background to the Term 'Spirit-baptism'}

The Greek concept of $\pi \nu \in \hat{\varphi} \mu \alpha$ is primarily one of a corporeal reality, which stands in contrast to the strict spiritual connotation of the NT. In both worlds, however, there is a parallel understanding of the action of $\pi \nu \in \hat{v} \mu \alpha$ in that it "as a

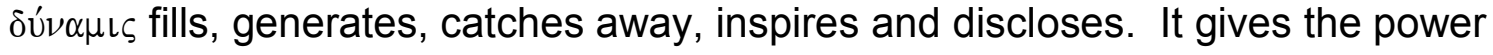
to say and do extraordinary things." ${ }^{2}$ Secular Greek regards $\pi \nu \in \hat{v} \mu \alpha$ as a thing, never the persona of the Spirit present in Christian thinking. ${ }^{3}$ In the NT the

\footnotetext{
1 F.D. Bruner, A Theology of the Holy Spirit: The Pentecostal Experience and The New Testament Witness (London: Hodder \& Stoughton, 1970), 57.

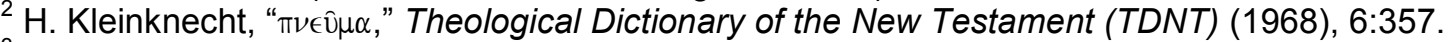

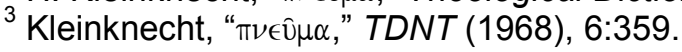


essence of $\pi \nu \in \hat{0} \mu \alpha$ is found in the Hebrew equivalent רֵּ (ruach) for which a variety of meanings are evidenced in the OT: ${ }^{4}$

i. Breath of the Mouth

"My breath is offensive to my wife" (Job 19:17). Another literal use is hard breathing in anger by man (Is 25:4). Anthropomorphically, Eliphaz has God breathing angrily (Job 4:9), and the Psalmist has God exercising divine fiat by the breath of his mouth (Ps 33:6). Metaphorically there is the sense of empty words as mere breath (Jer 5:13) and breath as the symbol of life (Gen 6:17).

ii. Wind or Breath of Air

"And God made a wind to pass over the earth, and the waters subsided" (Gen 8:1b). In directional terms, wind can be from the east (Ex 10:13), north ( $\operatorname{Pr}$ 25:23), west (Ex 10:19), the absence of a specific southerly wind being covered by reference to the four winds (Jer 49:36). In a figurative sense wind connotes futility (Job 7:7), a striving or grasping for the wind (Ecc 1:14).

iii. Life Principle

"And behold, I myself am bringing the flood of waters on the earth, to destroy from under heaven all flesh which is the breath of life" (Gen 6:17). Idols lack the breath of life (Hab 2:19), the entry of which into the bones in Ezekiel's vision brought life (Ez 37:6). If God takes this life principle away (Ps 104:29) or if it otherwise returns to him (Ecc 12:17) then men die. The animating action of is displayed in personal courage (Ps 76:13), temper (Jud 9:23), impatience (Mic 2:7), bitter disposition (Is 54:6), jealousy ( $\mathrm{Nu} 5: 14$ ), and prophetic enablement (Nu 27:18).

\footnotetext{
${ }^{4}$ The semantic divisions used here follow, with some modification, those used in F. Brown, S. R. Driver, C. A. Briggs, Hebrew and English Lexicon (Peabody: Hendrickson, 1979), 924-926. Cf. Yves Congar, I Believe in the Holy Spirit, trans. David Smith (London: Geoffrey Chapman, 1983), 2:3, who finds that ruach can be divided into "three roughly equal groups" viz. (i) wind or breath of air, (ii) principle of life, (iii) life of God, "the force by which he acts and causes actions."
} 
iv. Seat of the Emotions, Intellect and Will

Emotionally there is reference to inner disquiet (II Kings 19:7), despondence (Is 61:3), vexation (Ps 77:3), desperation (Job 7:11), religious feeling (Zec 12:10) and temper (Job 6:4). Intellectually, the positive meanings include cleverness (Dan 6:4), reason (Job 32:8), artistic sense (Ex 28:3), planning (I Chron 28:12). Negatively there is lack of perception (Is 19:14), lack of moral insight (Is 29:24) and erroneous thoughts (Ez 13:3). Volitionally has the nuances of resolve (Job 51:1), personal attitude (Pr 16:2), forbearance (Ecc 7:8) and unfaithfulness (Hos 4:12). The OT use of נִּנִ (nepesh) meaning psyche or anima, seems to have been gradually overtaken by רוּת which itself came to be defined as the centre of the personal self. ${ }^{5}$

רוּּת יהוה (ruach Yahweh) is often used to express God's endowment for special action, specifically: great bodily strength (Jud 14:6), ability to lead (Jud 3:10), visionary experiences (Ez 8:3), ecstatic utterance (Num 11:25). God's creative power is expressed by רוּ רוּ of his mouth: "By the word of the Lord, the heavens were made and all the host of them by the breath of his mouth" (Ps 33:6). The Spirit of God in the OT appears to act primarily in motivating the prophets, an action which earns the prophets the title "man of the spirit." The role of the Spirit thus is evidenced in the lives of Elijah (I Kings 18:12), Elisha (II Kings 2:9) and Micaiah (I Kings 23:21). ${ }^{7}$

In the OT the Spirit comes upon (sometimes mightily, viz. Jud 14:6, 19) individuals for a particular task using them instrumentally, for example King

For a definitive list of references consult Brown, Driver and Briggs, Lexicon,_and " $\pi \nu \in \hat{\nu} \mu \alpha, " T D N T$ (1968), 6:360-364.

${ }^{5}$ H. W. Robinson, "Hebrew Psychology," The People and the Book ed. A. S. Peake, (Oxford: Clarendon, 1925), 353-382, quoted in Alasdair Heron, The Holy Spirit (Philadelphia: Westminster, 1983), 6.

${ }^{6}$ Cf. Hos 9:7 "man of the Spirit." H. W. Wolff, Hosea: a commentary on the book of the Prophet Hosea, trans. Gary Stansell, ed. Paul Hanson (Philadelphia: Fortress, 1974), 157, states: "'man of the Spirit' is a synonym for 'man of God' for he was said to be overcome by the Spirit of God." So also D. A. Hubbard, Hosea, Tyndale OT Commentaries (Leicester: IVP, 1989), 159. 
Cyrus. Notable exceptions to this periodic external influence of the Spirit include Saul, David and Elijah. Presumably the Spirit stayed with Saul from the time that he was "turned into another man" (I Sam 10:6) until the Spirit of the Lord departed (I Sam 16:14). It is recorded in the previous verse (v. 13) that the Spirit of the Lord, on the occasion of David's anointing by Samuel, came "upon David from that day forward". Elisha requested a double portion of Elijah's spirit (II Kings 2:9) which implies that the spiritual immanence of the latter was something of a permanent nature.

While the absolute "the Messiah" does not appear in the OT, the idea of a Davidic messianic king is found, e.g. Ps 89:3-4 and Jer 30:9. Ezekiel, prophesying from the Exile, predicts that "David my servant shall be king" $(37: 24)$. The anticipation of prophetic literature was that the Davidic King would enjoy a permanence of the Spirit; Isaiah prophesying of Jesse's offspring says, "the Spirit of the Lord shall rest upon him" (11:2). Consequently OT portrayals of the Messiah depict a king who possesses extraordinary spiritual ability (Is 9:6; Zech 3:8ff).

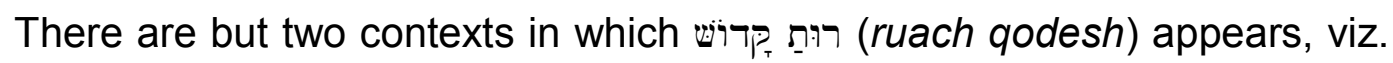
Ps 51:11 and Is 63:10-11. However, the phrase is qualified as God's Holy Spirit removing any sense of a divine personage, instead showing that God himself is the referent. M. E. Tate commenting on Psalm 51 believes that:

Any interpretation of the Holy Spirit in Ps 57 and Is 63 in terms of the developed understanding of the Holy Spirit in the NT and in Christian thought would be anachronistic. On the other hand, the Holy Spirit is the Spirit of God, as in the OT. . . . In a profound sense, there is but 'One Spirit'. 8

\footnotetext{
${ }^{7}$ That OT prophets were inspired by God's spirit is shown thus: Num 11:17; I Sam 16:15; Mic 3:8; Ezek 2:2.

${ }^{8}$ M. E. Tate, Psalms 51-100, Word Biblical Commentary (Dallas: Word, 1990), 24.
} 
In the intertestamental period, Judaism developed the notion that the spirit of prophecy died out with the last prophet (I Macc $4: 46 ; 14: 41)^{9}$ to be restored only to a purified Israel in the new age heralded by the Messiah. ${ }^{10}$ This sometimes resulted in the apocalyptic movement producing a supposed Messiah (cf. Acts 5:34-37). ${ }^{11}$ The community at Qumran thought itself to be part of Israel's messianic hope (I Q S 8:14ff) and progressively identified the spirit of prophecy with God's Holy Spirit. ${ }^{12}$

Although $\pi \nu \in \hat{\mu} \mu \alpha$ occurs 379 times in the NT, in only three cases does it portray its original meaning in the Greek world of strong wind or breeze. It is predominantly used of God's $\pi \nu \in \hat{\mathrm{u}} \mu \alpha$ (275 times), and frequently refers to the human $\pi \nu \epsilon \hat{\nu} \mu \alpha$ (47 times). ${ }^{13}$ The Gospels, Acts and Revelation associate $\pi \nu \in \hat{v} \mu \alpha$ with unclean or evil spirits (i.e. an animistic understanding of evil which inhabits people, influencing behaviour and causing sickness). Lk 24:37, 39 shows $\pi \nu \in \hat{\mathrm{u}} \mu \alpha$ as devoid of flesh and blood; elsewhere souls of both the righteous (Heb 12:23) and sinners (I Pet 3:19) are called spirits.

In English, the shades of the primary meaning of the word "spirit" include the animating principle in humans and animals, the immaterial part of a corporeal being, a spectre, the active power of an emotion, or the essential character of a thing. ${ }^{14}$ We can agree with Professor Moule ${ }^{15}$ who finds that "spirit," in its religious use, means whatever is otherworldly or incorporeal.

Jesus, in his first public exposition (Lk 4:16-30), shows that he understood his mission as Spirit-anointed. Although the sense of the Isaianic passage is

\footnotetext{
${ }^{9}$ Tosefta of the Talmudic Treatise Sota 13:2 reads: "Since the death of Haggai, Zechariah and Malachi, the last of the prophets, the Holy Spirit has ceased in Israel."

${ }^{10}$ Hobart Freeman, An Introduction to the Old Testament Prophets (Chicago: Moody Press, 1968), 130.

${ }^{11}$ See J. Klausner, The Messianic Idea In Israel: from Its Beginning to the Completion of the Mishnah, trans. W. F. Stinespring (New York: Macmillian, 1955), 394-399, for a discussion of the Bar-Cochba revolt.

${ }^{12}$ I QS 8:16, Zadokite II 12.

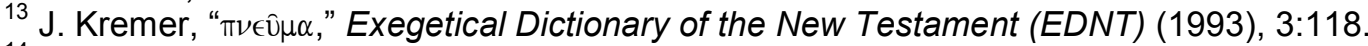

${ }^{14}$ The New Shorter O.E.D., (1993), 2:2989.

${ }^{15}$ C. F. D. Moule, The Holy Spirit (London: Mowbrays, 1978), 1.
} 
firstly prophetic, it is not unreasonable to find messianic significance. Jesus can therefore function as both prophet and king; however, the emphasis is on his spirit anointing. ${ }^{16}$ That Jesus knew the Holy Spirit to be a personality is evidenced by his calling Him the Paraclete; Jesus, the first Paraclete, will send another ${ }^{17}$ after he is gone, i.e. the Holy Spirit (Jn 14:26). Jesus, using the words of the Baptist's prediction (Jn 1:33), promises that his disciples would be baptised with the Holy Spirit (Acts 1:5). The juxtaposition of the promise (v. 4) with the predicted baptism (v. 5) identifies the one with the other. ${ }^{18}$

In secular Greek $\beta \alpha \alpha \pi \tau \omega$ means to dip in or under, sometimes used in reference to dipping into a dye. The intensive form $\beta \alpha \pi \tau i \zeta \omega$ carries the meanings of immerse, sink, drown, bathe, wash both in literal and figurative senses. $^{19}$ Philo of Alexandria writing in De Migratione Abrahami (204) of Joseph's food laws for Egypt, assumes that the abundance would cause over indulgence such that each of the senses "may wanton and drown ( $\beta \alpha \pi \tau i \zeta \eta)$ the mind under the weight of all that it devours." ${ }^{20}$ Plato, in his Euthydemus (277d) recounting the testing of young Cleinias at the hands of Dionysodorus and Euthydemus with difficult questions, tells of the latter about to press the youth for the third time when Socrates, perceiving he was "going under" ( $\beta \alpha \pi \tau i \zeta o \mu \in\llcorner o \nu)$, gave him breathing space by speaking encouragement to him. ${ }^{21}$

The NT uses $\beta \alpha \dot{\pi} \pi \tau \omega$ only four times (Lk 16:24; Jn 13:26a,b; Rev 19:13) and on each occasion it is with the literal meaning of "dip." B $\alpha \pi \tau i \zeta \omega$ appears far

\footnotetext{
${ }^{16} \mathrm{~J}$. Nolland, Luke 1-9:20, Word Biblical Commentary (Dallas: Word, 1989), 196, shares this view. See also D. Juel, Messianic Exegesis (Philadelphia: Fortress, 1988), 84.

${ }^{17} \alpha \dot{\alpha} \lambda$ ov $\pi \alpha \rho \alpha ́ \alpha \lambda \eta \tau o v$ Jn 14:16. Jesus does not explicitly identify himself as a paraclete; however, in the preceding verses he has described his anticipated role of helper. See J. H. Bernard, John, International Critical Commentary, ed. S.R. Driver, A. Plummer and C.A. Briggs (Edinburgh: T and T Clark, 1946), 2:545.

${ }^{18}$ Cf the parallel narrative Lk 24:49: "clothed with power from on high." Acts 2:33 makes the identification clear. See also E. Haenchen, The Acts of the Apostles, trans. Bernard Noble and Gerald Shinn (Oxford: Blackwell, 1971), 142 n.1.

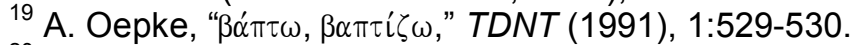

${ }^{20}$ Philo, De Migratione Abrahami, trans. F. H. Colson and G. H. Whitaker (London: Heinemann, 1958), 251.
} 
more frequently but only in the cultic sense, predominantly as a technical term for baptism. ${ }^{22}$

Jesus speaks of $\beta \alpha^{\prime} \pi \tau \iota \sigma \mu \alpha$ as the trial he must endure (Mk 10:38) the flood of suffering which will encompass him or, as W. Beider states, the "total human submersion into the most absolute God-forsakenness." ${ }^{23}$ In Paul's understanding of baptism the believer is incorporated into, and in fact puts on, Christ (Gal 3:27) so that one might say they are enveloped by Christ, reflecting the complete identification with Him in death, burial and resurrection (Rom 6:4).

The Baptist, in the version shared by Matthew and Luke, contrasts his own baptism, with the Spirit and fire baptism of the Coming One (Mt 3:11; Lk 3:16). ${ }^{24}$ Fire, used in both refining and destructive analogies, has the property of being all-consuming: the use here of fire to describe baptism serves to strengthen the connotation of baptism as an encompassing action.

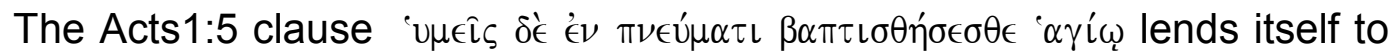
some ambiguity, the preposition $\epsilon \mathcal{} \cup$ having the possible meanings "by," "with," or "in."25 The majority of translations prefer "with." ${ }^{26}$ In modern parlance, however, the phrase "baptism of the Spirit" has emerged, at least as a substantive. $^{27}$ This phrase, unscriptural as it is, effectively communicates the power enduement to an individual rather than the inhabitation by the Spirit. ${ }^{28}$

\footnotetext{
${ }^{21}$ Plato, Euthydemus, trans. W. R. M. Lamb (London: Heinemann, 1962). This sense of "overwhelm" is a nuance given to $\beta \alpha \pi \tau i \zeta \omega$ by W. Bauer, W. F. Arndt, F .W. Gingrich and F. W. Danker, A Greek-English Lexicon of the NT (Chicago: University of Chicago Press, 1979).

${ }_{22}$ See G. R. Beasly-Murray, " $\beta \alpha \pi \tau i \zeta \omega$," Dictionary of New Testament Theology, ed. Colin Brown (Exeter: Paternoster, 1975), 1:144-145.

${ }^{23}$ W. Beider, " $\beta \alpha \pi \tau i \zeta \omega, "$ EDNT (1990), 1:193.

${ }^{24}$ That the baptism here is a single event is supported by J. Nollan, Luke, 152, wherein he discusses other variations in interpretation.

25 "With" connotes encompassing; "in" conveys the idea of the Spirit as the medium; "by" or more fully "by means of" implies that the Spirit is the agent. W. Elliger, " $\epsilon \nu$," EDNT (1990), 1:448. J. R. Williams, The Gift of the Holy Spirit Today (Plainfield: Logos 1980), 18, insists that "in" is the best translation due to its avoiding any connotation of the Spirit as baptiser and to its more natural qualifications of $\beta \alpha \pi \tau i \zeta \omega$.

${ }^{26}$ So NIV, NKJV, TEV, RSV, NEB, NJB, Moffat, Knox.

${ }^{27}$ It is a linguistic choice, as opposed to theological, which prefers the preposition "in" over "of" being used with any verbal construction involving baptise, e.g. was baptised in the Spirit.

${ }^{28}$ Cf Bruner, Holy Spirit, 60, where he describes Pentecostals as usually preferring the term "baptism in/with" rather than "baptism of" the Spirit. "For while every Christian, on becoming a
} 
An alternative phrase, taken from Acts 2:38, is "gift of the Holy Spirit"; other terminology derived from Scripture includes to "be filled with" (Acts 2:4), to "receive" (Acts 2:38) and to "be sealed by" (Eph 1:13) the Holy Spirit. ${ }^{29}$ Theologians in the Charismatic Movement prefer to speak of a "release of the Spirit" or "renewal of the Spirit" 30 which reflects a particular understanding of the experience.

\section{Pentecostal Proof Texts}

In terms of the biblical material it has not escaped the notice of Pentecostals that the Epistles offer little to support the doctrine of a subsequent and distinct work of the Spirit in the life of the believer. ${ }^{31}$ More than one writer has argued that Paul, in writing to established churches, had no need to develop a doctrine of Spirit baptism. ${ }^{32}$ If it be that the gospels anticipate the gift of the Spirit and the Epistles preserve it, then it is Acts alone which describes its bestowal and reception. This not withstanding, texts outside of Acts do find relevance in the doctrine of Spirit-baptism.

Pentecostals have been more inclined to do than to theorize, a disposition which has led to there being a paucity of literature addressing the doctrine of the Spirit. Certainly there is a dearth of material which defends the experience against contrary and, oft times, credible viewpoints. The Apostolic Church is no

\footnotetext{
Christian, has been baptised of or by the Spirit-as-agent (I Cor 12:13a), Pentecostals believe that not every Christian has yet been baptised by Christ-as-agent in or with the Spirit-aselement (Mark 1:8 par; I Cor 12:13b). That is, Pentecostals believe that the Spirit has baptised every believer into Christ (conversion), but that Christ has not yet baptised every believer into the Spirit (Pentecost)."

This system actually posits two spirits each baptising into the other, on account of Christ-thebaptiser being a spirit as opposed to acting physically. For a more detailed analysis see Roland $\mathrm{H}$. Wessels, "How is Baptism in the Holy Spirit to be distinguished form receiving the Spirit at conversion? A problem question for the Assemblies of God?" address given to the Society for Pentecostal Studies at 1990 Annual Meeting, 6-11.

${ }_{29}^{29}$ R.H. Riggs, The Spirit Himself (Springfield Mo: Gospel Publishing House, 1949), 63, finds seven terms viz. baptise, fill, receive, seal, anoint, fill and earnest (II Cor 1:21-22).

${ }^{30}$ Williams, Gift, ix.

${ }^{31}$ W. J. Hollenweger, The Pentecostals (Mineapolis: Augsburg, 1972), 350, determines that there is no justification in Paul but some in Luke for Spirit-baptism.
} 
different in this regard. Apart from a regularly produced magazine, publications amount to a few tracts and papers locally, with the occasional volume appearing from the UK or Australia. Despite the reticence to commit theological reflection to paper, Pentecostals in general, and the Apostolic Church in particular, firmly believe that the experience of Spirit-baptism, rather than having a questionable biblical rationale, is plainly taught by Scripture. The major texts used by the Apostolic Church to support the doctrine are the following: ${ }^{33}$

i. Acts 2:4. This is the central text whence Pentecostalism derives its name. If it is assumed that the disciples were Christians prior to Pentecost, then the reception of the Spirit on that occasion sets the precedent for all who follow in time. In order to maintain this position it is argued that the breathing of the Spirit by Jesus on the disciples (Jn 20:22) is either an enacted parable anticipating Pentecost or it is the regenerating work of the Spirit in conversion. The associated phenomenon of speaking in tongues as it appears in the Acts text is demanded by many Pentecostal groups as the evidence of having received the baptism of the Spirit.

ii. Acts 2:14-40. The Petrine sermon identifies the event with the subject of Joel's prophecy (Joel 2:28-32) and states that the promised Holy Spirit is "what you now see and hear" (v. 33). In response to the crowd's cathartic quest with respect to crucifying the Messiah, Peter details: repentance, baptism for forgiveness of sins, and the gift of the Holy Spirit. In relation to salvation,

\footnotetext{
${ }^{32}$ G. A. Reed "Pentecostal Truths 322" mimeographed notes to a course taught at Central Bible Institute, Springfield, MO. (1952-54), 17-18, quoted in Bruner, Holy Spirit, 69.

${ }^{33}$ Traditionally, textual support has been restricted to Acts. Two noted Apostolic writers who cite Acts references exclusively in their treatment of Spirit-baptism are: the former president of the Apostolic Church Council, Australia, W. A. C. Rowe, whose volume One Lord, One Faith (Bradford: Puritan, n.d.) lists Acts 2:12; 8:14-25; 10:44-48; 19:2-7; and lan Macpherson, sometime principal of the Apostolic Church Bible College, Penygroes, South Wales, in his work The Faith Once Delivered (Milton Keynes: Word (UK), 1988) has Acts 1:5; 2:39; 8:14-15; 10:44; 19:6. In an exposition of the New Zealand Apostolic Church tenets entitled Foundations of Our Faith (n.d.) written by J. Guerin for the National Office, the biblical basis offered in support of the eighth tenet, i.e. "The baptism of the Holy Spirit for believers, with signs following" is Acts $1: 8 ; 2: 1-4 ; 8: 16-17 ; 10: 44-46 ; 19: 6$. Pneumatology courses taught at Te Nikau Bible
} 
Pentecostals consider the receiving of the gift as sequential rather than coincident.

iii. Acts 8:4-25. The account of the Samaritan Pentecost is perhaps the clearest enunciation of Spirit-baptism showing an obvious separation of conversion and the falling of the Spirit. The fact that post-Pentecost conversion and water-baptism could occur without the individual receiving the Spirit indicates to the Pentecostal that a biblical pattern is emerging. That this experience is instantly verifiable is a foundational precept of the doctrine. The absence in the text of glossolalia - the sign evidenced at the Jerusalem Pentecost - leads Pentecostals to posit that observable signs must have accompanied the event in order to attract the attention of Simon the sorcerer. These signs, it is concluded, might reasonably include glossolalia.

iv. Acts 9:1-19. The account of Paul's conversion offers less clear support for the doctrine. If it be assumed that at the time of Paul's vision on the Damascus road he experiences salvation, then the filling with the Spirit at the hands of Ananias constitutes a distinct work.

v. Acts 10. The story of Cornelius can provide strong evidence for a distinct Spirit-baptism on the basis that he was a Christian prior to Peter's visit. In the event that a claim for Cornelius' existing status of believer cannot be sustained, protagonists argue that his experience is a representative of the ideal but that a sequence exists nonetheless.

vi. Acts 19:1-17. Paul's discovery of the Ephesian disciples points to the possibility of subsequence. ${ }^{34}$ Pentecostal commentators note that Paul's very

College, the training centre for Apostolic Church N. Z., used Williams' Renewal Theology, 2:181-207 as a text, which moves outside of Acts.

34 Subsequence is defined as an experience for all believers, known as "baptism in the Holy Spirit," which is separate from and sequential to the initial conversion event. The term "subsequence" was probably first used by F. D. Bruner in 1970 and consistently used in theological journals since. "Subsequent," as an adjective to describe Spirit-baptism, has been in use at least since 1845 when John Morgan wrote in the Oberlin Quarterly Review. 
asking of such a question implies that one can believe without receiving the Spirit.

vii. Mark 1:9-11. Jesus' baptism affords a model for the subsequent work of the Spirit in the Christian by analogy, viz. conceived by the Spirit and later endued for service when the Spirit descends upon him. The parallel for believers is new birth followed by empowerment for service.

viii. Galatians 4:6. Paul here indicates a sequence in the Spirit's work stating that because of sonship God sent "the Spirit of his Son into our hearts."

ix. Ephesians 1:13. According to Paul, those who have believed were sealed with the promised Holy Spirit, the action of sealing implied by the grammar to succeed the action of believing.

Drawing together the foregoing then, it can be said that a progression of thought is apparent in the biblical understanding of $\Omega:-1 / \pi \nu \in \hat{\cup} \mu \alpha$. The concept of רוּת as an impersonal supernatural power develops into one of divine presence, active in the world, who is the power of life, restoring relationship, bestowing gifts and inspiring individuals. With the belief developing that the רוּ had departed from Israel, correspondingly the anticipation grew for the messianic figure on whom it would rest. $ภ(-\pi / \pi \nu \in \hat{U} \mu \alpha$ in the Jewish world was used for good/evil incorporeal beings and in the Hellenistic, $\pi \nu \in \hat{u} \mu \alpha$ was understood as substance although it shared in its meaning ideas from both wisdom literature and the Greek philosophers. The NT finds $\pi \nu \in \hat{u} \mu \alpha$ expressing the higher intangible human capacities, for example, feeling and knowledge; the mood in which Paul presumes the Corinthians would want him to come was one of "love and a spirit of gentleness" (I Cor 4:21). However, the "spirit of faith" spoken of by Paul elsewhere (II Cor 4:13) has its meaning on a different plane, implying instead interaction with the Spirit of God. The notion of God active in human beings was ripe for consummation in the NT experience on the basis of the OT 
promise. The overwhelming action of God's Spirit on the individual is variously expressed but is more than adequately represented in the metaphor of baptism.

\section{Subsequence}

Pentecostal pneumatology has as its central feature the doctrine of Spiritbaptism. The coming of the Spirit on the Day of Pentecost (Acts 2:4) is identified as the fulfilment of Jesus' promise to the disciples to be baptised with the Holy Spirit (Acts 1:5). Those who received the Spirit at Pentecost are considered to have already been believers, hence the description of the event as an experience subsequent to salvation. Pentecostals find in the Acts accounts of the Spirit coming upon various groups, a pattern of experience thought to be normative for all Christians. The term "subsequence," therefore, relates to the doctrine of a post-conversion Spirit-baptism. Inherent in the doctrine of subsequence is the notion that the experience is not only temporally separate to conversion, but logically distinct to it. The theory does not demand, however, that a discernible time lag exist between salvation and Spirit-baptism; rather, the focus is on separability of the experience.

Wesleyan-Holiness and Higher Life groups predate pentecostalism in espousing the subsequent nature of Spirit-baptism. These earlier groups understood the second work of grace, which was sometimes experienced years after conversion, to effect sanctification or holiness. The uniqueness of pentecostal theology lies both in the understanding that the event provides empowerment for service and in elaborating the evidential nature of receiving the Spirit.

In positing a second work of grace, subsequence runs foul of evangelical and sacramental doctrines, which identify Spirit-baptism with conversion/initiation. This repudiation of any second work of the Spirit is carried 
over into the respective charismatic theologies, which explain the experience of the Spirit as an actualisation of that which is received earlier, either in salvation or water-baptism.

\section{Prophecy}

Jesus had explained (Lk 24:49) that the promise of the Father would bring enduement of power. The experience of the Spirit on the Day of Pentecost is the context for viewing spiritual gifts. Paul explains to believers in Corinth that the Holy Spirit distributes spiritual gifts and then relates such activity to the experience of being saturated with the Spirit (I Cor 12:13). Pentecostals equate this saturation (' $€ \beta \alpha \pi \tau i \sigma \phi \eta \mu \epsilon \nu)$ with baptism in the Spirit; consequently spiritual gifts are seen as expected sequelae of an experience of the Spirit. Spiritbaptism is therefore not an end in itself but a prerequisite to being supernaturally equipped by God for his service.

Prophecy, which appears in Paul's list of nine spiritual gifts (I Cor 12:8-11), may be defined, in a New Testament sense, as speaking forth the mind of God. Whereas Old Testament prophecy was largely predictive and the prophets themselves involved in performing miraculous signs, the scope of the New Testament prophet, as outlined by Paul is: edification, exhortation and comfort (I Cor 14:3).

However, the five gifts of the ascended Christ to the church, known as "ascension gifts" (Eph 4:11), include "prophet" as one of the functions listed. Commensurate with the status afforded the apostle, evangelist, pastor and teacher, the office of prophet is here in view. Even where the notion of the present-day office of prophet has been accepted, there has not been unanimous agreement on whether this implies governmental function. 
Apostolic Function

The meaning of the word "apostle" conveys the idea of one who is sent on a mission on behalf on another; the apostle has the full authority of the sender, but is also responsible to him. While this describes the commission of the original twelve, the office of apostle in New Testament times was not restricted to those chosen personally by the Lord. Certainly Paul and Barnabas were called apostles (Acts 14:14) and the list of others so designated runs to at least five. It is worthwhile to note that the ordination of Paul and Barnabas (Acts $13: 2,3)$ occurred in the company of prophets and undoubtedly in the context of prophetic utterance.

Nevertheless, a distinction exists between the Twelve and subsequent apostles in that Jesus promises to the former a future role of judging the tribes of Israel (Mt 19:28). This possibly refers to future Kingdom activity of the Twelve, if the "twelve tribes of Israel" is equivalent to the church. Given that being a witness to the Resurrection seemed to be a requirement for membership of the original apostleship (Acts 1:22), later apostles are necessarily of a different order.

The function of the apostle was to establish and oversee churches and to act in authority over them in matters of discipline and revelation. It is the complementary operation of the apostle and prophet in ecclesial government which characterises the Apostolic Church.

\section{Purpose}

The pentecostal doctrine of subsequence and the consequent prophetic expression make for a radical ecclesiology. The Apostolic Church of New Zealand is one denomination which has exhibited "divine government" as a corollary of the pentecostal experience. However, the movement's 
understanding of Spirit-baptism is by no means complete or static; some progression of thought is apparent. It is an aim of this thesis to chart that course, noting probable influences from theological antecedents as well as then-current thinking, and to provide an assessment of the present position.

That the Apostolic Church exists apart from other pentecostal churches reflects the revelation of the restoration of apostle and prophet ministry. While other pentecostal denominations exercise the gift of prophecy, the Apostolic Church originally went a step further in relying on utterances of divine origin to effect government of the church, including the formulation of doctrine. There is an obvious tension between the spirit of prophecy and the spirit of order: the first seeks to evoke in the hearts of people a will to transform, whereas the second invites members of an institution to conform. An important exploration, therefore, will be the Apostolic Church's understanding of prophecy, both historically and currently, and an appraisal of where the movement perceives the place of this gift to be in the life and governance of the denomination. This enquiry will lead to probing the effect of centralism on the movement and its inevitable counter-effect, an example being the situation surrounding the challenge to the Apostolic Church leadership presented by the alternate model of the Latter Rain.

The Apostolic Church, while responding to theological change within the pentecostal movement, has made little contribution to the debate with nonpentecostal evangelicals concerning the meaning of Spirit-baptism. Amongst pentecostals and charismatics, who would claim to have "received the Spirit," there exists a considerable lack of awareness of the respective theologies of the experience. Within the parameters of this study, then, a specific effort will be made to address these two issues, viz. Spirit-baptism and charismatic theology. 
The overall research project is to survey and critique Apostolic Church understandings of Spirit-baptism, prophecy and church practice. Given that the Apostolic Church in Great Britain derived from the Apostolic Faith Church, which in turn counted amongst it ranks veterans of the 1904 Welsh Revival, the theological mindset of the founders invites discovery. The difficult question of power within the movement will need to be addressed with some comment about how defence of particular doctrines positioned people to influence the denomination. This thesis, then, aims to explore not only the initial but the subsidiary functions performed by the subsequence doctrine within the movement.

\section{Methodology}

The approach taken in this investigation has been to analyse and critique the three primary interdependent facets of the Apostolic Church's existence, viz. adherence to the doctrine of subsequence, the practice of prophecy and the operation of divine government. In a study of this kind which explores the complex relationship between theology, praxis and human interaction, it has been necessary to utilise a variety of disciplines including biblical and modern historical theology, psycho-social analysis, history, and ecclesiology. Where this study touches core theological themes of the Christian Church, an attempt has been made to interact with standard works in order to establish the foundation on which Apostolic Church doctrine rests.

This project is heavily dependent on archived material generated by the New Zealand Apostolic Church ${ }^{35}$ and its British antecedents. These primary

\footnotetext{
${ }^{35}$ During the superintendency of Phil Underwood (1995-1997) free access was granted to National Office archives for the purposes of perusing the Apostolic Church council minutes. It is noteworthy that in 2002, despite my being an ordained pastor of the Apostolic Church (Australia), further access to the council minutes was denied by the present National Leadership Team. The research was not compromised, however, on account of a personal collection covering the years 1965 to the present being made available.
} 
written sources have previously received scholarly attention only for the purposes of establishing the historical record; therefore, there is no theological commentary on the relevant material with which this present work can interact. Consequently, the thesis presents itself as a first approach to an assessment of Apostolic Church distinctives. Of great importance are the interviews conducted with Apostolic Church pastors, some of whom were involved with the movement from the 1940s. These accounts provide otherwise unrecorded data; included in this are recollections passed on to these pastors from older colleagues or members of their congregations who themselves were participants in the beginnings of the Apostolic Church in New Zealand.

A valid contribution to the overall thesis is the assessment of the current doctrinal position on Spirit-baptism and an estimation of the influence generated by observed shifts in thinking. A necessary final step of the current work is to identify outcomes for the movement; therefore, this study concludes with a synthesis of the research and a formulation of a potential pathway for the Apostolic Church in the $21^{\text {st }}$ century.

In summary, the aim of this thesis is to analyse and interpret core Apostolic Church doctrine, examining and critiquing the implications as applied to prophecy and church order. This task has been undertaken using the Apostolic Church as the frame of reference. In so doing, a history of the denomination has been constructed from a theological perspective, and an "inside story" has emerged which unveils the influence of doctrine on church praxis. Having completed this unique exploration of the inner workings of the movement, the way is now open for a sociological analysis of the New Zealand Apostolic Church. 


\section{Author's Position}

The insider element of this research relates to my upbringing in, and subsequent association with, the Apostolic Church of New Zealand. My father, the late James Worsfold, was ordained a pastor of the Apostolic Church in his twenties and served in that capacity for nearly 50 years, including two terms as President of the Apostolic Church and subsequently becoming President Emeritus. I was therefore born into the household of an Apostolic Church pastor and my involvement with the movement continued through to when I left New Zealand in my late twenties. On my return after seven years overseas, fraternal links with the movement were established when I joined the staff of Greenlane Christian Centre (GCC), an independent charismatic church in Auckland which itself had its roots in the Apostolic Church. In the mid-1990s the senior pastor of GCC and myself responded to invitations to attend the annual National Apostolic Pastors' Conference, and Apostolic Church ministry was received at GCC from time to time during those years. While my ordination credentials are not with the Apostolic Church of New Zealand, I have had significant experience in the life of the church and continued interaction with various staff within the movement. Currently, I serve as a credentialed pastor in the Apostolic Church of Australia where I have lived since 1997.

This level of association enabled access to the movement's leaders, official and private records and, in general, facilitated candid response from those interviewed. Nevertheless, the Apostolic Church of New Zealand is a small denomination and it is quite possible that where negative sentiment existed toward an individual that, on occasion, a sanitised version of events was recounted by those being interviewed. As I was closely involved in the life of the church, the detrimental effects of unfortunate governmental decisions on my family and friends were easily noted; however, not being an office-holder in the 
movement meant I was not directly affected. I am therefore not unconnected with my topic of study, but as a former teacher of mine at Fuller Seminary observed, "objectivity in analysis and commitment in faith need not be mutually exclusive." 36

${ }^{36}$ Richard A. Muller, The Study of Theology: From Biblical Interpretation to Contemporary Formulation, Foundations of Contemporary Interpretation,ed. Moisés Silva, vol 7 (Grand Rapids: Zondervan Publishing House, 1991), xv. 


\section{CHAPTER ONE \\ APOSTOLIC CHURCH ORIGINS}

It is apparent that the beginnings of the Apostolic Church are of little interest to its leaders: the movement's national web-site contains no information at all concerning the origins of the denomination. ${ }^{1}$ Such is the scarcity of knowledge that the Maori and Pacific Island Council, under the leadership of Manu Pohio, an apostle and at the time National Leadership Team member, confused the 1904 Welsh Revival with the inception of the Apostolic Church in Britain and advertised their intention of leading a trip to Wales in 2004 to commemorate the hundredth anniversary of the movement. ${ }^{2}$ This error is not entirely without foundation: Apostolic literature has, until recently, consistently portrayed the movement as springing directly from the 1904 Revival. UK Apostolic writer, T. N. Turnbull, begins his history of the denomination with reference to the Welsh Revival and then states: "The Apostolic Church has often been spoken of as an outcome of this great Revival, many of its first leaders, and in fact many of its members, being born

\footnotetext{
${ }^{1}$ Two local church web-sites pay scant attention to the origins of the movement:

- Masterton Apostolic Church has the following statement in their "What Are We?" section: "The Apostolic Church world wide has roots in the revival in Great Britain in the early 1900's with the Church first being established in New Zealand in 1933." www.oasis.org.nz/church/

- Park City Church, New Plymouth, is even more vague, failing to mention in which country the movement has its origins while describing their genesis: "The Holy Spirit moved the forefathers of the Apostolic Church to plant churches world wide." www.parkcitychurch.org.nz/ApoNZ.htm

2 "The Maori and Pacific Island Council Vision 2001-2004," Apostolic News 21, no. 1 (2001): 5.
} 
again during the Revival years." ${ }^{3}$ His work serves to reinforce this inaccurate view.

Turnbull recounts how Apostolic Church founder Daniel Powell Williams was converted during the revival, became a minister of the Congregational Church in Penygroes and then of a pentecostal "flock at Penygroes." $\mathrm{He}$ leaves the reader with the impression that this latter group was the beginnings of the Apostolic Church; in fact it was not. This assembly was the independent Evangelistic Church, which Williams was attending and subsequently became the leader of as a result of a prophetic message; this particular utterance came from James Dennis, the assistant minister to William Hutchinson, leader of the Apostolic Faith Church. In the Evangelistic Church, pentecostal leadership became an issue, with the result that in 1913 Williams was locked out of the building prompting him to form another congregation with 60 supporters. Williams continued to relate to Hutchinson and the Apostolic Faith Church and later in the same year an Apostolic Faith Church building was opened near Penygroes with Hutchinson present at the service. ${ }^{5}$

Turnbull further extends his misrepresentation with a statement that belies the true relationship that D. P. Williams and his brother W. Jones Williams had with Hutchinson and his movement, saying the "assembly in Penygroes and other assemblies in Wales had fellowship at first with the Apostolic Faith Church in Winton, Bournemouth, the Headquarters of that church." The reference to "other assemblies" is not elaborated because it would highlight the fact that Williams' Penygroes congregation was part of a

\footnotetext{
${ }^{3}$ Thomas N. Turnbull, What God Hath Wrought: A Short History of the Apostolic Church (Bradford: Puritan Press, 1959), 13.

${ }_{5}^{4}$ Turnbull, What God Hath Wrought, 19.

5 James E. Worsfold, The Origins of the Apostolic Church in Great Britain: with a Breviate of its Early Missionary Endeavours (Wellington: Julian Literature Trust, 1991), 21, 26-29.
} 
group of Welsh Apostolic Faith Church assemblies. In the following sentence Turnbull inaccurately refers to this "fellowship" as simply a "connection." Described in such a way, the severance which later occurred between the Welsh assemblies and the Apostolic Faith Church headquarters could be downplayed by Turnbull, as simply a disagreement over administrative practices at Bournemouth. In the previous paragraph, Turnbull had given quite the wrong impression when, in reference to the brothers, he stated that "through their ministry the Apostolic Church was commenced in Penygroes." This conflation of history implies that the Apostolic Church arose de novo instead of being a schismatic daughter of the Apostolic Faith Church.

It seems that Turnbull has glossed over facts which would detract from a history of the Apostolic Church conveying anything less than divine arrangement and absence of conflict. There is therefore no reference to Williams' expulsion from the Evangelistic Church, his subsequent alliance with the Apostolic Faith Church and later schism to form the Apostolic Church. As a result, the influence of Apostolic Faith Church leader William Hutchinson on D. P. Williams has been totally ignored.

New Zealand pentecostal historian James Worsfold records that the expatriate ministers who filled the early ranks of the Apostolic Church New Zealand knew something of the schism but "were usually reticent to discuss the matter" and that questions on the topic were "answered vaguely with a reference to the Welsh Revival." Worsfold published his candid history of the movement in 1991 amid concern from British colleagues who disbelieved his presentation of the facts. $^{8}$ The reticence of the movement's leaders in the

\footnotetext{
${ }_{7}^{6}$ Turnbull, What God Hath Wrought, 19-20.

${ }_{8}^{7}$ Worsfold, Origins, 151, n. 4.

${ }^{8}$ Worsfold, Origins, xvii.
} 
United Kingdom to acknowledge the confrontational nature of the Apostolic Church's pathway to existence is further expressed by Gordon Weeks, who in the preface of his history, appealed to the fact that he was asked to write "an authentic history." Interestingly, the Apostolic Church Australia has exhibited a similar tendency to retell the history in a flattering light. John W. J. Hewitt, former Apostolic Church Australia President, in describing the birth of the movement refers to an outpouring of the Holy Spirit in the years following the Welsh Revival as the catalyst for the formation of pentecostal groups, some of which rejected the revelations of headship of Christ and five-fold ministry. The inability of pentecostal groups to respond to these truths, Hewitt wrote, caused the Apostolic Church to be birthed. ${ }^{10}$ A more blatant error in Hewitt's representation of history is his statement that the: "Apostolic Church" was the name "by which the movement was known from its inception in 1911."11

Considering again the leadership struggle in The Evangelistic Church, Penygroes, it is instructive to examine in a little more detail the contributing factors. Many of those converted during the Welsh Revival sought to maintain their spiritual fervour through involvement in house-based prayer-meetings, some of which evolved into churches. One such group was led mainly by Eben Griffiths and it was with this fellowship, known as The Evangelistic Church, that D. P. Williams became associated. ${ }^{12}$ Williams had, since 1906, been the minister of an independent Congregational chapel in Penygroes, but following the experience of Spirit-baptism in 1909 began to have fellowship with pentecostal groups while maintaining his own pastorate. In 1910 Williams

\footnotetext{
9 Gordon Weeks, Chapter 32-part of: A History of the Apostolic Church 1900-2000 (Barnsley: by the author, 2003), 2.

John W. J. Hewitt, "Beginnings," Australian Impact (March 2002): 5.

${ }_{12}^{11}$ John W. J. Hewitt, “Early Beginnings," Australian Impact (March 2004): 20.

12 Meurig Thomas and Arwyn Davis, interview with Luke Worsfold, Penygroes, 1989.
} 
withdrew from the Congregational Church, ${ }^{13}$ reinforced in his decision by a prophecy which indicated that the Lord had laid his hand upon him for "a work hitherto not revealed unto thee."14 Williams developed his connection with The Evangelistic Church, but it seems he did not see it as a "career move." For one thing, The Evangelistic Church did not recognise the need for a pastor, the responsibility for the assembly resting with the elders. Williams was to write later that the effect of the prophetic revelation was devastating, "my prospects, seemingly, hampered . . . I found myself denuded of all my plans and stripped of all my intentions." ${ }^{15}$ His first response was to undergo adult water-baptism, not a Congregational practice, and he was quickly recognised as one of the leaders of The Evangelistic Church. ${ }^{16}$

Hutchinson and his assistant, James Dennis, visited The Evangelistic Church later in 1910 and brought contributions in preaching and prophecy to the congregation. The invalid daughter of a local farmer was at the time very ill and they were invited to go and offer prayer for her healing. Without any prearrangement some of the leaders of the Evangelistic Church, including Williams, also arrived and joined in a prayer session. Surprisingly, Dennis prophesied that "the hour had come for the Lord to make known his choice in relation to the shepherd of his people." Williams was separated to the ministry with the laying on of hands and there followed a celebration of the Lord's Supper. ${ }^{17}$ The reticence of the congregation to recognise a pastor meant that

\footnotetext{
${ }_{14}^{13}$ Worsfold, Origins, 20.

${ }^{14}$ Turnbull, What God Hath Wrought, 18.

15 D. P. Williams, ed., Souvenir Exhibiting the Movements of God in the Apostolic Church (Penygroes: Apostolic Church Publications, 1933), 11.

${ }^{16}$ T. N. Turnbull, Brothers (Bradford: Puritan Press, 1963), 35.

${ }^{17}$ Worsfold, Origins, 21.

It is interesting that Turnbull obscures the fact that Hutchinson and Dennis were the originators of this move, referring to the two men simply as "two servants of the Lord." What God Hath Wrought, 19.
} 
Williams did not immediately assume leadership. The eventual appointment of Williams was no doubt aided by later prophecies within the congregation which conveyed that notion that "the one ordained was to take charge.." ${ }^{18}$ The influence of Hutchinson is evident in the fact that Williams wrote to him about his new position, the letter published by Hutchinson in his periodical Showers of Blessing. ${ }^{19}$ Eben Griffiths, originally the one with the most influence in the church, believed that the congregation wanted to appoint him as leader over the prophetically-nominated Williams. This, coupled with Griffith's doubts about the authenticity of pentecostal phenomena, fuelled the tensions surrounding the issue of pentecostal leadership. The Evangelistic Church divided over the issue, with the faction loyal to Griffiths gaining the ascendancy. This is the background to the episode mentioned earlier where Williams and his supporters arrived for a morning service on Wednesday $5^{\text {th }}$ March, 1913 , and found themselves locked out of the building. ${ }^{20}$

Williams' continuance in the leadership role shows that he accepted the divine guidance via the prophet and in this we see him jettisoning his Congregational understanding of church government in favour of a theocratic system. His diary shows that around this time much help was gained from the influence of Hutchinson through his ministry and personal conversations that took place during a convention at Swansea. Williams nonetheless felt the rejection greatly, his diary recording that he "asked God for strength to prevent bitterness." He attended at least two meetings of the trustees; however, his diary shows no record of any judgement, suggesting that there was no

\footnotetext{
${ }^{18}$ Turnbull, Brothers In Arms, 36.

${ }_{20}^{19}$ William O. Hutchinson, Showers of Blessing, no. 6:4.

20 Evangelistic Church leaders, Arwyn Davis and Meurig Thomas, recounting their understanding of the event; interview with Luke Worsfold, Penygroes, August, 1989.
} 
reconciliation. $^{21} \quad$ Following his expulsion from the Evangelistic Church, Williams, and those loyal to him, used a variety of premises to conduct services: the vestry of the Congregational church; an empty butcher's shop; an old salt store; and a school hall. ${ }^{22}$ Williams continued to strengthen his relationship with Hutchinson and the Apostolic Faith Church at Bournemouth, so it is not surprising that the latter was present, presumably in a presidory capacity, at the services to mark the opening of a new Apostolic Faith Church building in September, 1913, at Cross Hands near Penygroes. ${ }^{23}$ D. P. Williams had now fully identified with the Apostolic Faith Church and its leader, Hutchinson.

\section{W. O. Hutchinson and the Apostolic Faith Church}

William Oliver Hutchinson was born at Blackhill, County Durham in 1864 to Primitive Methodist parents and committed his life to serving God while still a young man: working as a shepherd in high country he became terrified during a thunderstorm and vowed to serve God if his life was spared. Later, in response to divine guidance, he enlisted in the military, eventually rising to the rank of sergeant in the Grenadier Guards where he maintained a strong evangelistic testimony. Hutchinson saw service in the Boer War, where he escaped death twice; however, when his health failed he was invalided home to a military hospital and returned to civilian life in 1903 to work as an inspector for the London Society for the Prevention of Cruelty to Children under the direction of its founder Benjamin Waugh. He functioned as a Methodist laypreacher initially, but adopted the theology of full baptismal immersion and therefore aligned himself with the Baptists. Reader Harris, founder of the Pentecostal League, held meetings in Bournemouth around that time, and it

\footnotetext{
${ }^{21}$ Worsfold, Origins, 27-28, quoting from Williams' diary.

${ }^{22}$ Williams, Souvenir, 13.

${ }^{23}$ Showers, no. 11:12.
} 
was through his influence that Hutchinson had a sanctifying experience referred to by Wesleyans as a "clean heart" before God. At the time he mistook the event for Spirit-baptism; however, he later adjusted his view to include tongue-speaking as an expected accompaniment to the pentecostal baptism. An interesting feature of Hutchinson's Christian experience is that he believed the Lord would provide for him financially, both in personal and ministry needs, in response to faith. It was this standard that affected his decision when he was invited to be the assistant pastor of the local Baptist church; he turned the position down, preferring instead to wait for the time when he would step out into ministry and be supported solely through freewill offerings. $^{24}$

Hutchinson was baptised in the Holy Spirit at the first of Alexander Boddy's Whitsuntide conventions in Sunderland in 1908. On his return to Bournemouth he conducted prayer-meetings in his home which proved to be successful in helping others experience Spirit-baptism. Feeling that the environment was not optimal to outworking the call on his life, Hutchinson eventually left the Baptists and conducted his own public services, preaching the pentecostal message with remarkable success: many were baptised in the Holy Spirit. ${ }^{25}$ Hutchinson felt the need for a centre from which he could extend his ministry to other locations and so in 1910 he erected a hall, an exercise he managed to complete without taking any public collections for money. Emmanuel Mission Hall, as it was known, became an epicentre of pentecostal activity. Testimonies of the pentecostal blessing occurring there and elsewhere around the country were published in Hutchinson's free periodical, Showers of Blessing which commenced in January, $1910 .^{26}$ Healing was a particular feature and each issue was prayed over in order that the sick would be restored to health upon reading it. Astounding testimonies appeared of

\footnotetext{
${ }^{24}$ Kent White, The Word of God Coming Again Winton, Bournemouth: Apostolic Faith Church, 1919), 29-46.

${ }^{25}$ White, Word, 47-48.

${ }^{26}$ Showers, no. 1:1.
} 
people who had applied the paper physically to the affected part of their bodies and received healing. ${ }^{27}$

The centuries-old opposition to the pentecostal message was felt no less keenly by Hutchinson and his followers in the early 1900s. Contention surrounded the teaching that the experience of Spirit-baptism, subsequent to conversion and attended by tongues-speaking, should be sought by all Christians. Misinformation concerning pentecostal practices was rife; Hutchinson recounted the story from one man who was given a warning not to attend Emmanuel Mission Hall. He was given further advice that if he did go, he should plead the blood of Jesus and he would be safe. ${ }^{28}$ However, he did attend and later testified that the Holy Spirit fell on him with the result that he spoke in tongues and prophesied. ${ }^{29}$ This immediate reception of the Spirit was not necessarily the norm and occasions known as "tarry meetings," where individuals could seek the infilling of the Spirit, became common. This "waiting" was not a passive exercise but involved the individual in passionately seeking the Lord for his touch and actively eradicating known sin from one's life. James Brooke, an assistant of Hutchinson's, wrote that he waited for six weeks for his experience, during which time he gained a deeper revelation of his "death union with Christ" and felt driven to surrender himself "unreservedly" to the Lord. ${ }^{30}$

In contrast with the Assemblies of God movement which, up until the 1950s, referred to their leaders simply as "brother," the Apostolic Church has always used the title "pastor" for those ordained to that function. This habit was probably inherited from Hutchinson who quickly adopted the title "pastor"

\footnotetext{
${ }^{27}$ Showers, no. 7:5.

${ }^{28}$ A similar situation existed 60 years later in New Zealand regarding antagonists' opinion of pentecostal behaviour. One Baptist family attending the Apostolic Church in Dunedin in the early 1960s were told that Pentecostals bit the pews, so when the congregation rose to sing a hymn the visitors felt along the top of the pew in front in order to find teeth marks. C. M. Worsfold to Luke Worsfold.

${ }^{29}$ Showers, no. 1:5.

${ }^{30}$ Showers, no. 5:1.
} 
of the work at Emmanuel Mission Hall, Bournemouth. Although Hutchinson was the established leader of the group of churches linked to Bournemouth, he resisted any formal recognition of such until the Bournemouth convention, 1913, where he was set apart as an apostle to the movement. ${ }^{31}$ There was a growing awareness that Hutchinson, as leader of the mother Apostolic Faith Church, should be recognised as the overall leader of the federation of congregations which was fast becoming a denomination. Kent White reports that in 1911, while leaders from the associated churches in England, Scotland and Wales were together in Bournemouth, prophecy came which outlined the need for the congregations to be united as one body called the Apostolic Faith Church and governed by a "chief apostle." Concerning their common future the geographically separated congregations had been receiving congruent prophetic messages which also specifically identified Hutchinson as leader. Importantly, at a meeting in Swansea, Wales the following year many leaders of congregations reaffirmed the choice of Hutchinson as leader. However, even in 1913 prior to the annual Bournemouth convention, Hutchinson was still unwilling to assume the overall leadership role to the extent that he was disinclined to convene the gathering. It was a member of the congregation in Bournemouth who seemed to have the requisite persuasive effect: the woman concerned presented herself at the church office and on her knees in front of Hutchinson and other leaders prophesied that "have I not spoken unto ye in that I have said that I have chosen one that shall stand forth, yea, in mine own place, saith the Lord, chosen, yea, and that one, that one is thee, mine anointed; for in very truth as it came through the mouth of another, art thou

\footnotetext{
${ }^{31}$ White, Word, 64-65.
} 
chosen as an apostle?"32 Hutchinson subsequently led the convention, during which Musgrave Reade preached a sermon entitled "The Gifts of the Spirit." In arguing for the preservation of apostleship in the church of today Reade said:

The seal of an apostle was that he was a founder of churches. Are there any today? I do believe so. I do believe that our dear brother, Pastor Hutchinson, should have that title as a founder of churches. This is his seal. He shows also the other marks of an apostle: I Corinthians 9:1 \& 2 . "Are ye not my work in the Lord; if I be not an apostle unto others, yet doubtless I am unto you, for the seal of my apostleship are ye in the Lord. ${ }^{, 33}$

Kent White's description of Hutchinson's ensuing nomination and ordination at that conference as being "through the gifts of the Holy Ghost," indicates that the process operated under prophetic guidance. ${ }^{34}$

The role of prophecy in providing direction for the movement was beginning to grow. In 1914, as a result of prophetic input, D. P. Williams and Andrew Murdoch were ordained as apostles for Wales and Scotland respectively, with Hutchinson being referred to, in print at least, as the "chief apostle." ${ }^{35}$ The first overseas missionaries, the newly-married $\mathrm{Mr}$ and Mrs Higgs-Roderick from Wales, accepted their commissioning to South Africa as a result of prophecy. ${ }^{36}$ It seems that for some time pastoral appointments had been facilitated by prophecy: for instance, at a December 1911 convention at the Arthur Street Chapel, London, the assembly leader, Dan Jones, was called by prophecy to be a full-time minister. ${ }^{37}$

\footnotetext{
${ }^{32}$ White, Word, 63-65.

${ }^{33}$ Showers, no. 12:6.

${ }^{34}$ White, Word, 64.

${ }^{35}$ Showers, no. 12:11.

${ }^{36}$ Showers, no. 7:4.

${ }^{37}$ Showers, no. 8:3.
} 
Hutchinson believed that the gifts of the Holy Spirit were unable to be contaminated by the human spirit. ${ }^{38}$ He was therefore able to place great store on the content of tongues and interpretation or prophecies uttered by the inspired. Yet not all utterances carried the same weight: he distinguished between the intermittent spirit of prophecy and the resident gift of prophecy. The pastoral ramification of this he made clear in his cautioning against making a hasty response to an utterance from one operating with the spirit of prophecy. This is surely his meaning when he advises a measured response to "any word which came through any one that the Spirit fell upon just at that time." Another safeguard he employed in the realm of the voice gifts, i.e. prophecy, tongues and interpretation, was for someone other than the one bringing a tongues message to interpret. These cautions notwithstanding, Hutchinson testified in 1911 that in respect of the guidance received by the Spirit they had "not found God once tell us an untruth, neither lead us astray."

Hutchinson expounded his doctrine in Showers of Blessing under the title "Teaching from the Word" covering the tenets of water baptism, the Lord's Supper, pleading the blood, and payment of tithes. ${ }^{40}$ Pleading the blood is one of the more esoteric doctrines and, while widespread, was not a universal pentecostal practice. According to Kent White it traces its origins in the $20^{\text {th }}$ century to an independent Scottish congregation at Westport Hall, Kilsyth where, in January 1908, a man called out "Blood! Blood! Blood!" several times during a service, whereupon 13 members of the congregation fell to their knees and experienced Spirit-baptism. The "blood" cry became a feature for

\footnotetext{
${ }^{38}$ Hutchinson writes: "Some say that the gifts of the Holy Ghost can be contaminated by the human spirit. We do not agree; we can nowhere see where this happened in Scripture, and it differs altogether with our experience." Showers, no. 7:3.

${ }^{39}$ Showers, no. 8:2.

${ }^{40}$ Showers, no. 6:5-6.
} 
many people having similar experiences and Kilsyth became a centre running nightly meetings for nine months to cater for seekers who came and received their baptism while pleading the blood. A. A. Boddy visited Kilsyth, coming under the influence of the teaching and incorporated it into his meetings in Sunderland. ${ }^{41}$ Hutchinson used Showers of Blessing to defend and expound the teaching, showing readers that the blood cry is a spiritual weapon to be used in warfare against the devil. ${ }^{42}$

\section{P. Williams and the Apostolic Faith Church}

In 1913 D. P. Williams produced his exposition of the 12 tenets of the Apostolic Faith Church, Fundamental Doctrines of the Apostolic Faith Church in Wales, compiled from Hutchinson's published teaching which had appeared over time in Showers of Blessing. This work Williams completed in Welsh but was nonetheless willing to state in the foreword that the Apostolic Faith Church in Wales was part of a larger ecclesial network throughout Britain. Williams was undoubtedly more comfortable with the Welsh language than English and his brother, Jones Williams, would preferentially prophesy in Welsh. Hutchinson defended Williams and another Welsh pastor against complaints concerning the standard of English they used in their articles published in Showers of Blessing, pointing out that "our Welsh Brethren are not speaking English every day and that any mistake observed . . . may be excused.."

\footnotetext{
${ }^{41}$ White, Word, 83-86.

${ }^{42}$ Hutchinson writes: "There is much to say in these days about the pleading of the Blood of Jesus, for the Baptism into the Holy Ghost. Some are saying that we might as well say Life as Blood. That is not so, beloved, as far as we can see there is "Death" and "Life" in the Blood. It is not sufficient, Life alone, but Death and Life. We do not plead the Blood of Jesus for a tongue as some suppose, but we do plead the Blood against the foe which oppose us. They overcame him (the devil) by the Blood of the Lamb and the word of their testimony (Rev. xii., II) . . . beloved, use the Blood of Jesus against the devil and you will see that he will flee from you, and the Holy Ghost will fall upon you, and you will speak in tongues as He gives utterance." Showers, no. 5:5.

Showers, no. 9:6.
} 
It does not appear that Williams was crusading for greater recognition of the Welsh language; he seems to be providing resources for the Welsh in the most appropriate form. It could be argued that he missed a prime opportunity to improve his readers' standard of English comprehension by not publishing his work in the dominant language of the British Empire, but then again Williams would not have been unaware of the decline in the usage of Welsh language in the early part of the $20^{\text {th }}$ century and may not have wanted to contribute to such a trend. Williams was, in the year of publication, set apart as apostle to Wales as noted earlier and he was undoubtedly feeling some independence in his operation. Given that Williams did not begin his ministry under the direct aegis of Hutchinson or the Apostolic Faith Church it is not surprising that he undertook the project on his own initiative and without funding from Bournemouth. ${ }^{44}$

Williams considered his publication of Apostolic Faith Church doctrines of sufficient theological worth to later include it in a bound volume of Riches of Grace, the official organ of the secessionist Apostolic Church, which broke away in $1916 .{ }^{45}$ It did not seem to bother him that the title of the booklet carried within it the name "Apostolic Faith Church." In this project Williams showed himself to be an independent thinker: he did not simply "cut and paste" Hutchinson's published work but drew from it to formulate his own systematic theology. He addressed the following subjects: (i) basic truths; (ii) Trinity; (iii) atonement; (iv) place of service of the Holy Spirit; (v) baptism of the Holy Spirit; (vi) miraculous gifts; (vii) sacraments; (viii) eternal punishment; (ix) orderly authority of the church; $(x)$ paying the tithe and the offering; (xi) second coming of the Lord Jesus Christ to reign on earth; (xii) possibility of falling from grace.

Williams did not slavishly follow Hutchinson either in the choice of theological topics or in his treatment of them. Hutchinson had not previously

\footnotetext{
${ }^{44}$ D. P. Williams, Fundamental Doctrines of the Apostolic Faith Church in Wales (Penygroes: Mercury Press, 1914), 3.

${ }^{45}$ This particular compilation of Riches of Grace was produced sometime after 1920 because it contained issues spanning the years 1916-1920.
} 
handled items ii, iii, iv, ix, xii and Williams did not address the doctrines of: pleading the blood; divine healing; justification; sanctification, topics which were central to Hutchinson's thinking. Here is a point at which the divergence between the Apostolic Faith Church and its schismatic daughter can be traced, later years giving evidence of the difference in emphasis in the two denominations. Pleading the blood has not been a ubiquitous feature in the Apostolic Church and healing, while welcomed, has similarly not achieved the status as a hallmark of the movement. Conversely, the orderly authority of the church, particularly the practice of divine government, has developed into a distinctive which historically has set the Apostolic Church in New Zealand apart from other pentecostal groups.

Particular examples of Williams' deviation from Hutchinson's treatment are found in the section on Spirit-baptism where he ignores New Testament references choosing instead to rely solely on Joel $2: 28$, and when dealing with the Second Coming he fails to mention the rapture theory. It is entirely possible that the brevity of each section in Williams' booklet has precluded mention of those items which would render his work $100 \%$ consonant with Hutchinson's; however, elsewhere differences in interpretation become apparent. A case in point is the respective understandings concerning the use of tithes: Williams believed the poor should be priority recipients, whereas Hutchinson saw the primary function of tithing to maintain the work of the church, which included the support of those in ministry thus enabling the ongoing spiritual nourishment of the Christian. ${ }^{46}$ Of course, given that the booklet was published only in Welsh, Hutchinson would have been unable to directly ascertain the variations in doctrine expressed in print by Williams.

\footnotetext{
${ }^{46}$ Williams wrote: "We believe that God in His Word has prepared a system to look after the poor and the needy and those who are oppressed, so that all the saints are safeguarded, so the poor as well as the rich can be faithful, without fear of persecution or oppression, by collecting a tenth of the total (the tithe)." Fundamental Doctrines, 14-15.

Hutchinson wrote that the tithe should be brought to the "store house, i.e. where we get our spiritual meat." Showers, no. 13:11.
} 


\section{Factors in the Formation of the Apostolic Church}

Hutchinson considered Williams to be his right-hand man and profiled him and the Welsh congregations regularly in Showers of Blessing. However, at a Sunderland convention Hutchinson met Andrew Murdoch from Kilsyth who was an elder of an independent congregation there which had experienced the pentecostal outpouring in $1908 .^{47}$ Their relationship strengthened to the extent that, in 1911, the congregation at Kilsyth was formally recognised as part of the Apostolic Faith Church in Scotland. ${ }^{48}$ At a convention in 1915 at Kilsyth, prophecy indicated that Scotland now stood next to England and so correspondingly Wales lost its position of favour. This relegation was reflected in the physical placement of Williams and Murdoch with respect to Hutchinson: up to this point at public gatherings Williams had always sat on the right-hand side of Hutchinson and Murdoch on the left, but now their respective positions were reversed. Williams was so distraught by this turn of events that he went up on a hillside to complain to the Lord in prayer, his agony driving him to tear up the grass with his hands. ${ }^{49}$

Hutchinson was either naïvely oblivious or deliberately attempting to portray the events of the convention in a positive light when he reported in Showers of Blessing that parochial tendency was subordinated to the common good with the Welsh and Scottish delegates praying for each other. ${ }^{50}$ However, the second of the two possibilities is more likely given that Hutchinson has taken the trouble to mention national interests. He was not unaware of the importance of national identity in Great Britain at the time: at the same

\footnotetext{
${ }^{47}$ White, Word, 183. Hutchinson attended the Sunderland convention in 1908 and received his baptism there in a meeting where, according to White, "Murdoch was an active worker." It was the subsequent manifestation of spiritual gifts at Bournemouth, following Hutchinson's baptism, that led to his being invited to Kilsyth in 1909 for ministry.

${ }_{48}$ Showers, no. $16: 8$.

${ }^{49}$ Letter written in 1938 from John McPhee, leader of the Apostolic Faith Church, Glasgow, to T. V. Lewis, leader of the Apostolic Church, Glasgow. McPhee sought to correct published misinformation concerning the origins of the Apostolic Church which did not acknowledge the contribution of Hutchinson and the Apostolic Faith Church. Copy of letter in the papers of James Worsfold.

Showers, no. 16:7.
} 
convention, in recounting the setting apart of Williams in 1910, Hutchinson said he felt presumptuous in ordaining a man from another country. ${ }^{51}$ Yet as editor of Showers of Blessing he was able to publish a message in which he was compared to Gideon, being portrayed as the movement's leader not only in England but also in the countries across the border. The writer, W. HiggsRoderick, having described the activity of the biblical hero, asked "have we not the same today throughout England, Scotland and Wales, all being taught by the one voice, all being led by this one man, Gideon, this one commander, all being brought into the one heart?"52

The logo of the Apostolic Faith Church has as its focal point a sturdy fruit tree displaying a strong and elaborate root system on which the words "One Body" are inscribed. Encircling the tree is a ring containing the church name together with the words "Water" and "Blood;" a sunburst provides the backdrop for the complete picture. The revelation of the Apostolic Faith as perceived by Hutchinson was referred to as "the root," and in a way Bournemouth, as the headquarters of the church, came to fulfill this description. ${ }^{53}$ The branches of the tree represented satellite congregations throughout the United Kingdom and overseas, the unity of the movement being maintained by dependence on the root for revelation, ${ }^{54}$ that is, through Hutchinson the chief apostle.

Prophecy had set Hutchinson in place as the movement's leader and the prophetic word had sidelined Williams and the Welsh from their place of privilege. Revelation via the prophet was considered equal in authority to Scripture and this was a doctrine accepted by Williams. ${ }^{55}$ What was not

\footnotetext{
51 Showers, no. 16:8. Hutchinson was also concerned at ordaining a man to be leader of a work with which he himself had no link.

${ }^{52}$ W. Higgs-Roderick, "Gideon's Army," Showers, no. 13:16. Higgs-Roderick was a recently returned Apostolic Faith Church missionary to South Africa.

${ }^{53}$ A representative example of such usage is provided by Williams in a sermon delivered at the 1915 August conference in Bournemouth when he refers to the commonality of divine movement in Scotland, Wales and "at the root." Showers, no. 19:12.

${ }^{54}$ White, Word, 68. White also explains that "endless chain encircling the tree, crossing at the rear, is the power of the Word and the Blood that will bind all people together into one body."

55 James Hutchinson-Dennis contributed an article to Showers of Blessing, no. 14:4, in which he affirmed the equality of the written and spoken word saying: "There is no difference at all, because if it is the Word of God, whether it be written or spoken it cannot be anything else but
} 
received by Williams and his Welsh colleagues was the autocratic and centralised form of government which operated from Bournemouth. Apostolic Faith Church minister in Glasgow, John McPhee, years later recounted a statement made by Williams who said that "I am too staunch a Welshman to permit Pastor Hutchinson to place an Englishman over Wales." ${ }^{56}$ While McPhee does not indicate when Williams said this, the expressed sentiment at least is clear.

Williams relied heavily on the prophecy coming through his brother, W. Jones Williams; however, none of it was ever published in Showers of Blessing, Hutchinson preferring to promote words coming through James Dennis, his son-in-law, and a Mrs Kenny. Given Hutchinson's understanding in relation to the weight of prophetic words, it can be seen how he thought Williams' use of prophecy would undermine the authority of the apostle. Conversely, Williams was wary of a leader who harbours thoughts of being indispensable and pointed to Saul, who lost the power to rule and was replaced by a reliable leader identified via the prophet Samuel. He conveyed this thinking in his last published sermon in Showers of Blessing before he seceded and it is possible he was directing his comments at the regime in Bournemouth. ${ }^{57}$ Earlier in the sermon he refers to the blessing of there being a common thread to the ministry occurring in Scotland, Wales and "the root," so it is clear that it was not the ministry itself to which Williams was reacting, rather the hierarchical organisation exhibited by Bournemouth.

God's Word, and therefore in that sense it is the same identically. Most Christian people believe and the saints in this Church certainly do, that the written Word of God is infallible and given by Holy Ghost, from beginning to end. We also declare that the spoken Word of God given through the gifts of that Holy Ghost, which He has imparted for that purpose is infallible, and of God from beginning, to end."

It is apparent that Williams accepted this doctrine although later in print he cautioned against considering the words of "developing channels" to be $100 \%$ inspired. See Chapter Four, "Prophecy."

${ }_{57}^{56}$ Letter from John McPhee to T. V. Lewis, leader of the Apostolic Church, Glasgow, 1938.

57 This view is shared by James Worsfold in his in-depth analysis of Williams' break with Hutchinson in Origins, 139. 
Williams and his Welsh colleagues in the Apostolic Faith Church were concerned that institutionalism would creep in and destroy the spiritual life of the movement. ${ }^{58}$ The Apostolic Church in New Zealand preserved this mood, an often-heard cry in later years being, "we are a movement, not a monument!" ${ }^{59}$ Although not obvious from the overt and implied mutual approvals published in Showers of Blessing, there existed tensions between Hutchinson and Williams which compounded over time to the extent that the two were finally unable to work together. ${ }^{60}$

The Decrees of the Apostolic Faith Church were published by Hutchinson in 1916, describing in just 15 pages the organisational structure of the movement based on regional governance by an apostle. This system was already operating in the sense that Williams was overseer of Wales and Murdoch of Scotland but was developed to include apostles with authority over a district assisted by an associated presbytery. An apostle over a nation was likewise assisted by a national presbytery. Prophets were recognised; however, their utterances required apostolic confirmation before they could be acted upon. ${ }^{61}$ Hutchinson almost certainly did not draw up the decrees without consultation with Williams and Murdoch; however, for Williams the establishing of such guidelines, while reassuring in terms of maintaining spiritual autonomy, may have contributed to his fear of institutionalism developing within the movement.

We have previously noted Hutchinson's preference for relying on the Lord for financial sustenance in the ministry, but financial pressures were building and he ultimately had to abandon his principle of non-solicitation for

\footnotetext{
${ }^{58}$ T. V. Lewis, former president of the council, Apostolic Church, Great Britain, to James Worsfold in Palmerston North, 1951. Recorded in Worsfold, Origins, 145.

${ }^{59}$ This was a statement I remember hearing in my youth, particularly in conventions.

60 Miss Aida Hutchinson-Dennis, daughter of James Hutchinson-Dennis; Raymond Pain, retired Apostolic Faith Church minister, both interviewed by Luke Worsfold, Bournemouth, August 1989.

The Constitution of the Apostolic Faith Church in Great Britain (Bournemouth: Apostolic Faith Church Publications, 1916), 7.
} 
contributions towards Showers of Blessing. ${ }^{62}$ Earlier, in mid-1915, he had requested via a circular that tithes from all Apostolic Faith Churches be sent to Bournemouth, a move which not only signalled headquarters' need for funds but provided further provocation for the Welsh to secede; it was the central control of income and property which provided the major impetus for Williams to lead his revolt. ${ }^{63}$ Interestingly, when the directive came concerning the centralisation of funds, Williams and his brother were publicly supportive, even using prophecy to challenge a reluctant member of the congregation in the Swansea assembly to publicly state his support of the Bournemouth administration. In an ironic twist, when the secession occurred this individual did not follow Williams, who by that time had obviously changed his stance on the issue. ${ }^{64}$

In the light of the subsequent secession two possibilities in relation to the Williams brothers' ostensible position emerge: either they were fabricating their support for the headquarters edict, or their opposition to the centralised administration rapidly developed in the second half of 1915 . The fact that prophecy was used to challenge the Swansea assembly member unwilling to support Bournemouth indicates that the brothers Williams genuinely submitted to their leader's request, as it is unlikely that they would utilise the prophetic to publicly address an issue, all the while harbouring an opposite conviction. Therefore, the only other conclusion is that the tensions which had existed over time exerted a cumulative effect such that separation seemed the divinely ordained way ahead.

The Secession

\footnotetext{
62 Showers, no. 22:9.

${ }^{63}$ A. Hutchinson-Dennis and R. Pain, interview with Luke Worsfold, Bournemouth, 1989.

${ }^{64}$ W. Bidder, correspondence held by James Worsfold. Bidder attended the Apostolic Faith Church in Wales prior to 1916.
} 
The role of prophecy in influencing the discontent of the Welsh leading up to the break with the Apostolic Faith Church must not be underestimated. The following recollection serves to illustrate this point:

After a service during the August conference in Bournemouth in 1915, Dan Williams, James Forward, Caleb Morgan, William James, and Jones Williams (all ministers of the Apostolic Faith Church in Wales) were outside on the footpath, discussing the future of their movement, when a spontaneous word of prophecy came through the prophet Jones Williams informing the little conclave that 'the time was near when the action they were contemplating should occur. ${ }^{, 65}$

This word is more an endorsement than a directive and, as such, achieves a lower level of authority. Nevertheless, it was obviously sufficient for its purpose, January 1916 marking the occasion of 20 Welsh assemblies seceding from the Apostolic Faith Church. Seventeen years later Williams referred briefly to the former relationship with Hutchinson, maintaining that:

The time came when the Lord desired us to sever this connection in January, 1916. This of course proved to be the best for the Welsh section as time passed on. The Word was still multiplying and increasing. Doors were opening. Night and day, we were striving to cope with fresh demands. New assemblies were established."

For Williams to state that the "Lord desired" the break indicates not only an unshakable conviction in the appropriateness of the secession but also, given the standard operating practices of the Apostolic Faith Church, that the communication of the Divine will came via prophecy.

The leaders of the seceding group did not apparently consider it important to elaborate on their actions, at least not in print. The secessionists produced their own publication, Riches of Grace, and the first issue published

\footnotetext{
${ }^{65}$ Stanley James, son of William James featured in this event, to James Worsfold in 1988. Reproduced by Worsfold in, Origins, 152, n. 2.

${ }^{66}$ Williams, Souvenir, 13. Advertised in Riches of Grace as a "readable and interesting memoir," the Souvenir was published to coincide with the opening of the Apostolic Church Temple, Penygroes, August, 1933. Riches 8, no. 6:304.
} 
in April 1916 carried only a brief notice near the back of the magazine which read:

NOTE.- We wish to call the attention of our readers to the alteration which has recently been made in the name of the Church. Henceforth we shall be known as The Welsh Apostolic Church. We desire also to emphasize the fact that we do not hold any connection with The Apostolic FAITH Church whose headquarters are at Winton, Bournemouth, the Lord in His own way and time having effected a separation. Our headquarters are now situated at Penygroes. ${ }^{67}$

The content and placement of this notice is incongruous with the change to which it refers. A new movement had begun, with a new official magazine, but this fact was described as a name change in an unobtrusive notice featuring incidentally in the publication. This reticence to disclose implies an attempt to minimize the event. The only hint of the magnitude of the change is the force of the statement which distances the new group from the Apostolic Faith Church. Attributing the motive for separation to the Lord removes any complicity on behalf of the seceding group, the break consequently taking on the sense of deliverance from an obstacle to the divine plan; noticeably, there is at this point a lack of appreciation expressed toward the parent body.

The passage of time ameliorated this attitude. In an article written in 1933, Williams first explained that the relationship with the late Pastor Hutchinson had existed for a number of years but was severed due to "Church government and Church property, as well as other matters" which he considered inadvisable to discuss in "such a brief memoir as this." Then, in reference to Hutchinson, Williams acknowledged that "a great blessing was derived through his instrumentality at the commencement of the work. There were many qualities to his credit which were worthy of admiration."68

\footnotetext{
${ }_{68}^{67}$ Riches 1, no. 1:13.

${ }^{68}$ Williams, Souvenir, 13.
} 
Williams, having lost his divinely-appointed position as assembly leader in 1913 to Eben Griffiths did not want to suffer again, this time at the hands of Hutchinson, when the Welsh churches in the Apostolic Faith Church were promoting Williams as their highest leader. In other words, not wanting to yield leadership of the Welsh assemblies to another, especially a non-Welshman, Williams leads his colleagues in a secession. Fuelling Williams' desire to detach from Bournemouth was the increasingly irksome issue of central control of finances and property; Wales was numerically the strongest of the Apostolic Faith Church regions and, while not attracting the wealthy to their ranks, undoubtedly generated a significant portion of the church's income. Add to this the importance of prophecy to the movement as a whole and the content of utterances coming via the Welsh prophets concerning their own direction, and all the components for a schism were well in place. It is difficult to pinpoint a single precipitating factor as having the major influence in the action of seceding; rather, it appears that a complex interaction of psychological, ideological and pragmatic factors combined to provide the impetus.

In the first issue of Showers of Blessing for 1916, Hutchinson was keen to reinforce the notion that the prophet is to be in subjection to the apostle ${ }^{69}$; in the same issue an article by A. J. Seal observes that some want to prioritise the prophet over the apostle. $^{70}$ Apart from this veiled reference to Williams and

\footnotetext{
${ }^{69}$ Hutchinson writes: "I have always looked upon it as being in the voice part that the miracles will be wrought, but I see much in this, that prophecy is not first; do not let us think that. Whatever word comes through a prophet, that prophet is to be in subjection to the first gift, the apostle, and it must be so; this is God's order. If a prophet prophecies a Word, then the apostle handles that Word. Wisdom and knowledge, as God has declared, are in the apostle, and he rules that Word by that God-given wisdom and knowledge." Hutchinson, "Divine Love," Showers, no. 21:5.

${ }^{70}$ In a section entitled "The Necessity of Divine Order," Seal writes: "At the beginning we heard the Holy Ghost speak, and how we rejoiced even in tongues, interpretation, and prophecy. Yet how soon we found that these were not all, and that they were but for a purpose, even that the Divine order which says first apostles, secondarily prophets, etc., might be established. . . Some want to place the prophet before the apostle; others desire tongues
} 
those seceding, the effect on Hutchinson and his thoughts on the matter did not appear in Showers of Blessing. Kent White, however, provides some background in his book The Word of God Coming Again. In a section entitled "The Falling Away of Some" he refers to:

Some brethren outside the English membership, who came into the work, went out, desiring to be independent; they did it in the face of strong words of exhortation, formerly spoken through the gifts in use among themselves, declaring that in no wise should they separate from the movement at Bournemouth: that in it was the plan and order of God for them. ${ }^{7}$

Here White is no doubt referring to the Welsh who, he explains, thought that new conditions brought about a change in God's plan for them; however, White said that the chosen course of action would "prove to be of great cost" to those who had separated. It had been a "severe ordeal" for Hutchinson and the church, not to speak of the break in unity with those who were a "loved brotherhood." White charged that the apostleship of those seceding had become "merely nominal" but he affirmed that prophecies given by those who had left concerning the "apostleship and plan" would remain on the records of the church. This was to attest to the truth of God's word and to be a witness against the schismatics. There followed a description of the steel works in Wales which refines metal, disposing of the "worthless particles in the ore," drawing an analogy with the purging process the Apostolic Faith Church endured. From this it would seem that the Welsh were considered impurities

only, ignoring interpretation and prophecy; others want gifts of healing without the other gifts; in fact, each desires to carry this out-pouring and to control it as other sects are controlled; all it seems ignoring the Divine order as revealed at the beginning; yet we know that God cannot be contained on these man-made institutions. If God has ordered this ark to be carried on the shoulders of apostles and prophets, let us look for and expect these to be revealed by the Holy Ghost. Do we desire healings that we might rush hither and thither? - Then let us accept also the sure word of prophecy which will first of all work out the will of God in us. Do we desire prophecy? - Then let us acknowledge the first gift, even the apostle whose duty it is to rightly divide the word of God and to establish the Churches." A. J. Seal, "New Carts," Showers, no. 21:2-4.

${ }^{1}$ White, Word, 69-70. 
not able to withstand God's refining fire. It is surely not coincidental that White chooses a steel factory in Wales with which to make his analogy. ${ }^{72}$

The next section of White's book is entitled "The Judas Spirit Still Abroad on the Earth" and mentions the injury sustained when one who is a co-worker and a brother in the Lord becomes a "strong and bitter assailant of our very life and the calling of God in it." The aggressors are not further identified but White does state that Hutchinson had worked hard for these people, in some cases bearing debts of up to $£ 100$. The story of Julius Caesar's assassination by his friend Brutus is used as a parallel of the betrayal of Hutchinson, but with the concluding thought that a sure sign of God's moving is the opposition of evil forces. $^{73}$ The perspective of the current Apostolic Faith Church leader in Britain, Duncan Lee, is that here White is possibly referring to the later action of James Brooke who seceded to form the United Apostolic Faith Church. ${ }^{74}$

The Welsh found a new sense of identity after the break, the first issue of Riches of Grace presenting up to half of the material in their own language; this increased to two thirds over the next two years, reverting to fifty percent subsequently. By 1920 this fraction had reduced to a quarter and by the early 1940s it was only the occasional prophecy which appeared in Welsh. The new movement lost no time in consolidating their position by convening a two-week series of special services at the Welsh Apostolic Church in Llanelly a month after the secession. Interestingly, Robert Jardine, an English pastor who was one of the speakers, was anointed as apostle for England. The report in Riches of Grace discloses that "though this brother was unknown to the saints in Wales, yet through many prophets - wide apart, without any means of

\footnotetext{
${ }^{72}$ White, Word, 70-72.

${ }^{73}$ White, Word, 72-75.
} 
communicating one with the other - came the prophetic word that this brother was chosen for the apostleship." ${ }^{75}$ Such was the success of the special services at Llanelly that they were followed by additional meetings at Penygroes. Andrew Bell, a former leader in the Apostolic Faith Church in Scotland is reported as also being "with us" and it is reasonable to assume that he contributed to the preaching at the Penygroes services. Clearly, Williams and his Welsh colleagues had no difficulty in associating with ministers from "over the border"; however, in this situation they were firmly in control.

The missionary spirit born into the Apostolic Faith Church transmigrated into the Apostolic Church of Wales. On one particular evening during the above-mentioned Penygroes services the preaching focussed on the need of the unsaved to receive "the Light" with the result that many offered themselves for overseas missionary service. ${ }^{76}$ However, for the first two years the Apostolic Church in Wales remained true to their name, the list of the assemblies and their overseers which appeared on the back page of Riches of Grace during 1916-1917 confirming that no congregations outside of Wales were counted as their own. In 1920 the register of the assemblies in Wales was once again carried in Riches of Grace, only now there was an additional list under the heading "Other Assemblies in Co-operation and Fellowship with

\footnotetext{
${ }^{74}$ Duncan Lee, email to Luke Worsfold, 26 March 2004. Lee informs that subsequently White himself "broke away and left the church."

${ }^{75}$ Riches 1, no. 1:16. Jardine remained in association with the Apostolic Church only until the end of following year. In 1923 Jardine was ordained into the ministry of the Church of England, becoming the Vicar of Darlington, County Durham in 1937. An interesting detail of Jardine's biography is his offer to perform the marriage service for HRH the Duke of Windsor and Wallis Simpson, in a direct contravention of the ban imposed by the Church of England bishops. The Duke accepted, and his marriage to the twice-divorced Simpson went ahead at the Château de Candé, France, that year with Jardine officiating. See Charles Higham, Wallis: Secret Lives of the Duchess of Windsor: The Scandalous Truth About the Century's Most Infamous Woman (London: Pan Books, 1989) and Robert S. Jardine, The Supernatural in a Commonplace Life (Los Angeles: B. Robertson Company, 1944).

${ }^{76}$ Riches 1, no. 1:16.
} 
the above" which identified congregations at Birmingham, Hereford, Glasgow and Belfast.

In the same issue letters from the ministers of all four churches were published. Andrew Turnbull from Glasgow wrote that "the Brethren from Wales" gave his congregation much instruction on church order. ${ }^{77}$ Turnbull's congregation had affiliated with the Apostolic Church in Wales in 1919 during a visit by D. P. Williams and his brother W. Jones Williams. Turnbull describes this event in the previous issue of Riches of Grace recounting that the Lord had directed his independent congregation to temporarily adopt the name "The Burning Bush" and that further divine instruction would come as to when the next change should occur. He explained that "when the Apostle and Prophet came, it was changed. Now it is The Apostolic Church."78 It was a similar message from William Guest, leader of the Birmingham assembly, who said that the "Apostolic Revelation is coming into existence in our midst." Birmingham also had received ministry from the "Welsh brethren" who officiated at special services over the Christmas period. ${ }^{79}$ Frank Hodges wrote briefly concerning special ministry received by the Hereford church from a Welsh delegation which included the Williams brothers. He referred to the visit producing a "bond of fellowship between the Penygroes and Hereford Churches." Ben Fisher from Belfast gave a glowing report of a visit of D. P. Williams and six other Welshmen together with Andrew Turnbull to hold a twoweek series of meetings. Fisher concluded by affirming that the Belfast church is "intent on going forward on the path and in the Order we have been

\footnotetext{
${ }^{77}$ Riches 1, no. 9:18. This visit most probably occurred in the year that it was reported viz. 1920.

${ }^{78}$ Riches 1, no. 8:8. See also T. N. Turnbull, Apostle Andrew (Bradford: Puritan Press, 1965), 49.

${ }^{79}$ Riches 1, no. 9:13.
} 
shown." Introduction to and acceptance of the doctrine of divine government of the church through the restoration of the New Testament offices of apostle and prophet was, in essence, the common theme in the letters. Even the correspondence from the Hereford church, while not explicitly mentioning divine order in church government or related terminology, displayed deference to the Apostolic revelation by attaching the titles "Pastor" and "Prophet" to Dan and Jones Williams' names respectively.

This divine government operated on a small scale to begin with. D. P. Williams and Thomas Jones, both ordained to the apostleship several years earlier while in the Apostolic Faith Church, were the only two apostles initially before prophecy at the Penygroes International Convention in 1920 called Andrew Turnbull, leader of the Apostolic Church in Scotland, to join their ranks. ${ }^{82}$ Similarly, W. Jones Williams and Omri Jones, both of whom had been ordained to the prophetic office in the Apostolic Faith Church, carried over their function in the break-away movement. ${ }^{83}$ In the 15 years following, the apostolate expanded in number, including the recognition of an independent pentecostal preacher in Tonypandy, Thomas Rees. ${ }^{84}$

While prophecy may have brought Turnbull into the role of apostle, it was the presumably prophetic word which later directed him out of Glasgow to North England, where his ministry failed to achieve the heights it had in

\footnotetext{
${ }^{80}$ Riches 1, no. 9:28.

${ }^{81}$ Riches 1, no. 9:24-25.

${ }^{82}$ Turnbull, Brothers, 54.

${ }^{83}$ Worsfold, Origins, 181, states that Ernest Boulton with W. Jones Williams and Omri Jones "remained the only major prophetic voices in the Apostolic Church in Wales until 1922." However, in the list of churches and overseers published in Riches of Grace, Boulton's name appears initially as a pastor and as an assistant overseer, but not as a prophet. Further, it was only in 1920 that prophets were identified on the list and by then Boulton had already left the movement. In 1917 he was sent under prophetic guidance from Wales to a congregation in Scotland where he experienced difficulties and resigned only to later join George Jeffreys and become a founding member of the Elim Foursquare Gospel Alliance.

${ }^{84}$ Turnbull, What God Hath Wrought, 37-39.
} 
Scotland. Turnbull struggled with this decision of the, by now, centralised Apostolic Church government, finding fulfilment in overseas ministry in lieu of satisfaction in the local scene. ${ }^{85} \quad$ Turnbull had operated a system of government in Scotland which did not restrict decision-making to the apostles and prophets; rather, he included all ministers of the relevant district in the process and, as James Worsfold observes, this contributed to the success of the movement there. ${ }^{86}$ The principle of autonomous control contrasts strongly with the centralism which damaged both the work in Scotland and the ministry of Turnbull.

Initially the Apostolic Church assemblies were required to send all tithes to Pastor Thomas Jones at Llanelly and free-will offerings to D. P. Williams at Cross Hands, near Llanelly. ${ }^{87}$ By 1925 D. P. Williams had instituted a system where local expenses, including allocations to the poor, were met from locallysourced giving, with the central fund claiming the remainder. ${ }^{88}$ Tithing became $^{2}$ a core belief just as it had been in the Apostolic Faith Church although the administration differed in that the leader of the new movement did not have ultimate power over the finances as Hutchinson apparently did. The choice of someone other than Williams to collect and administer the tithes shows an effort on behalf of the Apostolic Church to redress this issue.

From the outset the Apostolic Church publicised its doctrine, the very first issue of Riches of Grace carrying an almost credal statement inside the front cover under the heading "The Apostolic Church in Wales." It read:

\footnotetext{
${ }^{85}$ Turnbull, Apostle, 70-75.

${ }^{86}$ Turnbull, Apostle, 57-59; Riches 3, no. 7:344; 6, no. 4:87-88.

Worsfold, Origins, 200, states that the work in Scotland has "never achieved anywhere near the same spiritual and numerical results as it did when Turnbull was the leader."

${ }_{88}^{87}$ Riches 1, no. 1:14.

${ }^{88}$ Worsfold, Origins, 182.
} 
We place on record some of the doctrines of our faith: we believe in the whole Word of God; the Trinity; the atonement; the place and service of the Holy Spirit; the baptism of the Holy Spirit; the miraculous gifts; the sacraments: the holy supper and baptism by immersion; eternal punishment; the second coming of our Lord Jesus Christ to reign on earth; the possibility of falling from grace. ${ }^{89}$

The statement continued, referring to recognition of "the Apostolic pattern" to bring direction to the church and, in an echo of Ephesians 4:11, the giving of spiritual gifts by the Holy Spirit to enable His people to accomplish their ministry for the building up of the body of Christ. Importantly, the statement spoke of submitting to the authority of the apostles to fulfill the whole word of the Holy Spirit through the prophets, with all the shepherds working together to secure obedience to the word of the Lord. Tithes and offerings received mention as being not of an obligatory nature but of a free-will. Finally, divine healing as a confirmatory sign of the preached word was endorsed with the text: "They shall lay hands on the sick, and they shall recover."

Williams streamlined this creed, distilling it down to 11 tenets which appeared on the inside cover of Riches of Grace in the first issue for 1920. By now the bulk of the magazine was being published in English; there is therefore no loss of subtlety in meaning through translation of the tenets which are:

i. The Unity of the Godhead and the Trinity of the Persons therein;

ii. The utter depravity of human nature, the necessity for repentance and regeneration, and the eternal doom of the finally impenitent;

\footnotetext{
${ }^{89}$ This statement appeared in Welsh as the first half of the inaugural issue of Riches of Grace was in the Welsh language; however, the ratio of Welsh to English in this publication decreased over time. The original statement is as follows:

Gosodwn yma rai o brif erthyglau ein ffydd: Credwn yn yr oll o Air Duw; yn y Trindod; yr lawn; safle a gwasanaeth yr Yspryd Glan; Bedydd yr Yspryd Glan; y Doniau Gwyrthiol; yr Ordinhadau; y Swper Sanctaidd a Bedydd trwy Drochiad; Cospedigaeth Dragywyddol; Ailddyfodiad yr Arglwydd lesu Grist i deyrnasu ar y ddaear; a'r posiblrwydd i syrthio oddiwrth ras.
} 
iii. The Virgin Birth, sinless Life, triumphant Resurrection, Ascension and abiding Intercession of our Lord Jesus Christ; His Second Coming and Millennial Reign upon earth;

iv. Justification and Sanctification through the finished work of Christ;

v. The Baptism of the Holy Ghost for believers, with signs following;

vi. The Gifts of the Holy Ghost for the comfort, edification, and building up of the Church, which is the Body of Christ;

vii. The Sacraments of Baptism by immersion, and of the Lord's Supper;

viii. The Divine Inspiration and Authority by the Holy Scriptures;

ix. Church Government by Apostles, Prophets, Evangelists, Pastors, Teachers, Elders, and Deacons;

x. The possibility of falling from Grace;

xi. The obligatory nature of Tithes and Offerings. ${ }^{90}$

Apart from additional ideas incorporated into tenets two and three, and changes in the order of some of the other ideas expressed, a comparison of the "credal" statement with the tenets shows a high degree of alignment. One interesting modification is in the nature of the tithes and offerings; in the earlier declaration they were both described as "free-will," whereas in the formulation of the tenets the giving of same had become "obligatory."

In 1922 a group of pentecostal congregations in Bradford came into relationship with the Apostolic Church in Wales. At a meeting of leaders from Wales, Scotland and England, prophecy from W. Jones Williams nominated three localities as centres for particular administrative functions in the church: Glasgow for finance, Bradford for missions, and Wales for government.

\footnotetext{
90 Riches 1, no. 9, inside front cover. The original capitalisation has been preserved. A comparison of the original "credal" statement with the tenets shows close alignment; additional phrases appear only in tenet numbers two and three.
} 
Further prophecy from $\mathrm{W}$. Jones Williams the following day announced that the Lord would destroy opposition to his plan; the strength of such a word acted to forge the various parties into common fellowship. ${ }^{91}$ Consequently, the name "Apostolic Church in Wales" was amended to simply, "Apostolic Church," a move which signalled a de-emphasis of parochialism amongst the Welsh and the acceptance of a mission oriented vision.

Prophecy at the Bradford conference through W. Jones Williams and others saw the establishment of a 28-member governing body called the General Council of the Missionary Movement with D. P. Williams nominated as "President." The council, which had regional representation from Scotland, North England, the Midlands and Wales, operated within specified limits dealing only with items of a missionary nature. ${ }^{92}$ Of particular importance was the prophetic word which said, "I will answer the cry of the globe, I will belt the globe yet; the fight from the beginning has been against my voice..$^{93}$ In this the prophet, W. Jones Williams, was referring to the opposition from other pentecostal groups to the practice of divine government in the Apostolic Church. $^{94}$

The Apostolic Church in New Zealand

\footnotetext{
${ }^{91}$ Turnbull, Brothers in Arms, 54.

92 Apostolic Church Missionary Herald 1, no. 10 (1927): 383. See also Souvenir, 16, and Worsfold, Origins, 216.

${ }^{93}$ Worsfold, Origins, 220. A similar thought is echoed by D. P. Williams: while giving an exposition of a Welsh prophecy in 1927 he says that, in reference to the covenant of Calvary "we have a part in every Mission Meeting of the Church to claim the globe for Jesus." Apostolic Church Missionary Herald 2, no. 4 (1928): 78. At the 1931 Penygroes convention W. Jones Williams prophesied, "I will belt the globe! I will reach the nations!" Riches 7, no. 6 (1932): 252.

Williams speaks of the hostility from the pentecostal leaders in the UK who took the unprecedented step of forewarning churches in the USA of an impending delegation of Apostolic pastors across the Atlantic in 1922. Souvenir, 16.
} 
Wellington was the first New Zealand city to receive the Apostolic Vision. John Hewitt, a member of the Apostolic Church in Wales accepted an Assemblies of God pastorate in Auckland in 1927 and thence to Wellington the following year. In the Wellington congregation other expatriate Welsh, who were also from the Apostolic Church, stimulated discussion on apostle and prophet ministry which resulted in a fellow church member, Alex Wright, starting services along Apostolic lines in a rented hall in 1928. Difficulties arose over the function of prophecy, Wright being unhappy with the level of influence prophetic words through one particularly active channel, Mrs R. G. Baker, were having on church direction. In a scene reminiscent of that endured by D. P. Williams over 20 years earlier, Wright attempted to lock-out the other leaders; however, they gained entry and the planned service proceeded. Those targeted by the lock-out separated themselves, convening meetings in an alternate location provided by Baker and her husband which operated under the banner of the Apostolic Church; Wright discontinued his services in early $1933 .{ }^{95}$ It is interesting to note that the party at the centre of the controversy was also the one which provided the premises for the breakaway meeting.

Appeals to the Missionary Council for a pastor to lead the Wellington assembly were initially answered in the reconnaissance carried out in 1933 by William Cathcart, who three years earlier had been sent from the United Kingdom to pioneer the work in Australia. Cathcart conducted a revival crusade in the Wellington Town Hall and called for assistance in evangelism from John Hewitt who was by then in Australia. ${ }^{96}$ No opportunity was lost to promulgate the distinctive theology of the movement; Cathart, following the end-times focussed crusade, preached at a communion service on the topics

\footnotetext{
${ }^{95}$ Worsfold, Origins, 254, outlines these events using information obtained from Wright's first wife, Marjorie Blick and from founding member of the Apostolic Church in Wellington, Jack Flyger.

${ }^{96}$ Worsfold, A History of the Charismatic Movements in New Zealand: with a Breviate of the Catholic Apostolic Church in Great Britain (Wellington: Julian Literature Trust, 1974), 239.
} 
of Apostolic Church government and the offices of apostle and prophet. ${ }^{97}$ Hewitt, together with his brother, Isaac, campaigned in New Zealand, working in the realms of revival and divine healing. The following year Joshua McCabe relocated to New Zealand from the United Kingdom and together with Hewitt exercised the ministries of prophet and apostle respectively. ${ }^{98}$ The first members were received into fellowship of the Apostolic Church by Hewitt during a communion service in Wellington, 1934. In the same meeting McCabe nominated, by prophecy, church officers who were then set apart to their calling by Hewitt. ${ }^{99}$ This apostle - prophet ministry was augmented by the visit later that year of D. P. Williams and his brother Jones, both of whom brought a global understanding of the movement and its vision to those who had aligned with the Apostolic Church in New Zealand. ${ }^{100}$ However, the practice of using prophecy to guide the appointment of church officers drew criticism from other pentecostal groups. ${ }^{101}$

Hewitt and McCabe both returned to Australia for different reasons and so the Welshman Alfred Greenway was sent from Britain in 1934 to oversee the work in New Zealand. He was joined the following year by Englishman J. F. D. Thompson who relocated to Nelson, the place decided upon by the Missionary Council in Bradford, England. ${ }^{102}$ In 1936 another Welshman, Ivor Grabham, arrived in New Zealand in response to an appeal for a prophet and in a leadership transition that year Thompson became the "Acting Superintendent." Cathcart relocated to Japan in support of the work there in 1937, whereupon Thompson was confirmed as superintendent for the New Zealand church. ${ }^{103}$ Expatriates continued to fill the leadership positions in the

\footnotetext{
${ }^{97}$ Revival Echoes 1, no. 8:123.

${ }_{98}^{98}$ Worsfold, Origins, 255-257.

Revival Echoes 1, no. 9:143.

${ }_{101}^{100}$ Revival Echoes 2, no. 10:191.

${ }^{101}$ Worsfold, History, 242, derived this information from a founding elder in the Wellington congregation, Alex Scott.

${ }^{102}$ Worsfold, History, 243, 246, 249. McCabe returned the next year to continue his ministry as preacher and prophet.

Worsfold, History, 254-259.
} 
New Zealand church and when autonomy was granted in 1942 it was Alex Gardiner, a Scot living in Australia, who was appointed president as a result of prophetic confirmation. Gardiner imported the centralist ideas prevalent in the Great Britain church to New Zealand which, while effective in the early years when the movement was small, quickly proved to be a rate-limiting factor in the growth of the church.

Prophecy was involved not only in nominating men for office but also served as the conduit of revelation concerning reshuffling of personnel between pastorates. Interestingly, by the early 1940s the role of prophecy in church government was already being criticised as not reaching its potential and so in an effort to address this issue the New Zealand leadership appealed to Great Britain for help. Britain responded by sending two senior ministers in 1942, H. Dawson and W. Rowe, and in the discussions that followed not only was a position taken on the question but the New Zealand church was granted full autonomy. ${ }^{104}$ Thompson's title therefore changed to "President," a secretary was appointed and a council and executive were established. At this meeting it was decided that the pastoral term should be four years before consideration could be given to a change.

The standard for ministers was considered to be complete adherence to the doctrines of the church although there existed the facility for clarification of any undefined doctrinal points via the council, the decision of which was considered binding. ${ }^{105}$ Similarly, it was required of prospective members of the Apostolic Church that "they have accepted the tenets of the church and will be amenable to the government."106

In 1943 the New Zealand church formulated a constitution based on the United Kingdom version; however, numerous alterations have been made over

\footnotetext{
${ }^{104}$ Minutes of Dominion Council, Wellington, July 1942, pp. 28-47, record these discussions. See analysis of this point below, Chapter Four, "Prophecy," 154.

${ }_{106}$ Minutes of Dominion Council, Wellington, July 1942, pp. 4-10.

${ }^{106}$ Constitution of the Apostolic Church, New Zealand, 1943.
} 
the years by successive councils. ${ }^{107}$ According to the constitution, nomination to any one of the five-fold offices, by an apostle or via prophecy, required confirmation by the council before ordination could proceed. Even the executive could not overrule the council. ${ }^{108}$ Appeals from the New Zealand church to Great Britain for ministerial help were generally met by supplying another pastor, this practice continuing up until 1954 with the arrival of the last expatriate to join the New Zealand staff. It was not until 1962 that a New Zealand-born man was appointed president of the council. This reliance on the "Mother country" to provide ministry personnel tended to overlook the potential existing locally, creating a situation where a lowered expectation on behalf of the New Zealand council with respect to the less experienced pastors limited their level of achievement. ${ }^{109}$

Less than 30 years after its official inception in New Zealand, the Apostolic Church Council felt the need to issue a manifesto proclaiming the necessity for renewal in order to stave off institutionalisation of the movement. Referring to their "consolidation rather than aggressive expansion," the document expressed the need of revisiting the passion of the early years when the "God-given apostolic revelation" first appeared to them. Proclamation of the apostolic vision, the manifesto declared, necessarily follows evangelistic endeavour. ${ }^{10}$ What they were saying is that without converts there is no-one to receive the revelation. The Apostolic Church of New Zealand, having begun on the platform of evangelism accompanied by signs and wonders was, after nearly three decades, making a call for a return to origins.

\section{Summary}

\footnotetext{
${ }_{108}^{107}$ Worsfold, History, 269, n. 3.

${ }^{108}$ Worsfold, History, 274, makes mention of a particular episode in 1944 but this characteristic is also evident in reading the council minutes covering the period 1965-1990.

${ }^{109}$ Worsfold, History, 276, attributes such thinking to some who were members of the council in 1946; it is most likely that Worsfold has his father-in-law C. C. Scadden in view here.

${ }^{110}$ Minutes of the Dominion Council, Wellington, April 1960, pp. 12-13.
} 
The recurring theme of schism in the origins of the Apostolic Church highlights the difficulty of achieving objectivity when divine guidance is appealed to in the setting of church government; as noted in the previous chapter, renewal movements are by their very nature divisive. The unenviable pathway taken by D. P. Williams through the several denominational affiliations is only possible if there exists in the heart a firmly-held belief that the Holy Spirit is continually drawing one on to a purer and higher service. For Williams his relationship with Hutchinson was catalytic; not only did the latter set him apart as a minister of a particular fellowship, but he demonstrated the role of apostle in the context of a prophetically inspired movement, viz. the Apostolic Faith Church. Unfortunately, it is apparent that Williams resisted institutionalisation only to see it influence the movement he pioneered. Furthermore, in the excitement surrounding the revelation of restoration of apostolic and prophetic offices, there failed to be a recognition that prophecy is not infallible, but rather noticeably vulnerable to the human spirit. Whereas prophecy seems to have had a distinctly unsettling effect in guiding the relocation of personnel, it has been singularly successful in defining emphases and providing overall direction for the movement. If it were not for the prophecy to "belt the globe," then the Apostolic Church would never have been established in New Zealand. 


\section{CHAPTER TWO}

\section{SUBSEQUENCE}

Factors that occasion present day Pentecostalism are none too different from those of various enthusiastic groups down through the centuries. ${ }^{1}$ The same quest for an experience of God that is apart from the mystical and yet equally revelatory is evident now as much as it was then. A wide range of theological and sociological concerns interact with the individual's drive for relationship with God in order to generate "enthusiastic" expression. In the pentecostal tradition it is the baptism of the Spirit that has been, and remains, the experience that to some extent signals a realisation of powerful communion of the believer with God. ${ }^{2}$ At this point it will be instructive to examine the Apostolic Church's understanding of a number of issues related to Spiritbaptism, attempting in the process to identify any progress of thought over time.

The information for this and following chapters was sourced from interviews with past presidents and former senior ministers of the Apostolic Church NZ, who were active in the years 1950-1986, and material published by the denomination. ${ }^{3}$ Initially the doctrinal magazine of the Apostolic Church in

1 For an historical survey, a starting point, albeit not unbiased, would be Ronald Knox, Enthusiasm: A Chapter in the History of Religion (Oxford: Clarendon Press, 1950). See also, Cecil M. Robeck, ed, Charismatic Experiences in History (Peabody, MA: Hendrickson Publishing, 1985). For a more popular treatment see Eddie L. Hyatt, 2000 Years of Charismatic Christianity: A 21st Century Look at Church History from a Pentecostal-Charismatic Perspective (Dallas: Hyatt Press, 1998).

2 By way of qualification it should also be noted that most pentecostal traditions do not teach that the Spirit-baptised believer has in any way "arrived" or achieved perfection--rather he or she has been initiated into a process of repeatedly being filled with the Spirit.

${ }^{3}$ The following presidents contributed: term of office shown in brackets.

I. L Cullen

[1962-1968] 
Great Britain, Riches of Grace, served as the official organ of the daughter church in New Zealand. The Witness Newsletter had begun in July 1941 as a publication of the Young People's Movement of the Apostolic Church in NZ. However, it developed from being a source of local information to a magazine of articles and reports, both domestic and overseas, thus its name changed to The World and New Zealand with the first issue in March $1947 .^{4}$ The World and New Zealand was in turn renamed Treasures of Grace when, in 1956, the Apostolic Church decided to publish a quarterly periodical to serve as the Church's official organ. The name underwent a further change in 1968 becoming Apostolic Life. ${ }^{5}$ Currently the movement produces a bi-monthly newspaper, The Apostolic News.

A major premise of Pentecostal doctrine is subsequence. The exposition of the Apostolic Church (UK) tenet concerning baptism in the Spirit quotes a prophecy given in 1932 which underlines the importance of the experience thus: "You are to testify to all men that after they are converted and have obeyed the other commands of God, they should tarry until they are filled with that power." The third issue of Riches of Grace (then known by its Welsh title Cyfoeth Gras), published in 1917, carries an article by the Apostolic Church cofounder William Jones Williams, in which he affirms the biblical command to "tarry" for Spirit-baptism in order to be equipped for divine service. He states: "This blessing is absolutely different to regeneration. We are born again unto
M. Goulton
[1968-1976]
W. W. Pearson
[1976-1980]
J. E. Worsfold
[1980-1986]

Note: the four presidents previous to I. L. Cullen are all deceased.

Other senior ministers who contributed:

E. Hendery; A. Arnold.

${ }^{4}$ The World and New Zealand 1, no. 1 (1947): 3.

${ }^{5}$ James Evans Worsfold, A History of the Charismatic Movements in New Zealand: Including a Pentecostal Perspective and a Breviate of the Catholic Apostolic Church in Great Britain (Wellington, Julian Literature Trust: 1974), 280-281. 
the Kingdom, but we must be baptised of the Spirit into the mystical body of Christ." Early pioneer William Rowe contended that "the very term Baptism of the Holy Spirit points out and emphasises a special and unique experience which the believer is expected to receive AFTER the New Birth. It is something separate and additional and follows the experience of salvation." ${ }^{8}$ Thomas Turnbull, an Apostolic Church minister and author of several books wrote: "We receive the baptism of the Spirit after we believe. As Paul wrote: ' . . after that ye believed, ye were sealed with that Holy Spirit of promise' (Eph. i: 13). Belief must precede the reception of this, one of God's greatest gifts." ${ }^{9}$ The identification of the gift of the Holy Spirit with regeneration, continually challenged by the Apostolic Church, received attention in a sermon at the movement's annual convention in Penygroes, 1962: "Regeneration is the WORK of the Spirit, not the gift of the Spirit. Regeneration is associated with repentance, but the gift of the Holy Ghost can only mean the Baptism with the Holy Ghost and associated with His Person rather His work."10 The speaker, C. H. Rosser, marvelled at the ability of anyone to interpret Acts 2:38 otherwise. The all-important statement followed: "Regeneration is a preparatory work to the Baptism of the Spirit." There was obviously a deep commitment to the doctrine of subsequence which, of course, is at variance with Reformed and Lutheran theologies. ${ }^{11}$

\footnotetext{
${ }^{6}$ The Apostolic Church: Its Principles And Practices (Penygroes: Apostolic Publications, 1937), 199.

${ }^{7}$ William Jones-Williams, "The Infallible Word of God," Riches of Grace 2, no. 1 (1917): 13.

${ }^{8}$ William A. C. Rowe, The Pattern of Pentecost (n.p., n.d.), 19.

${ }^{9}$ Thomas Napier Turnbull, The Full Gospel (Manchester: Puritan Press, 1949), 19. In further explanation he distinguishes between two powers received by an individual Christian, viz. the power to become a son of God (Jn 1:12) and the power to be a witness (Acts 1:8). Ten years later, the consistency of belief in subsequence is evident in his What God Hath Wrought (Bradford: Puritan Press, 1959), 156: "It may be three days, or three weeks, or three months, or even three years, but it is sometime after we believe that we will be baptised with the Holy Spirit." ${ }^{10}$ C. H. Rosser, "The Church and its Mission," Riches 15 (October 1962): 306.

${ }^{11}$ While not embracing the notion of a second work of grace, evangelical theologies do speak of the ongoing work of the Spirit in the life of the believer. Bruce Milne, Know the Truth: $A$ Handbook of Christian Belief (Leicester: IVP, 1998), 238-250, lists hope, assurance,
} 
Otto Weber, in his Foundations of Dogmatics, tackles the subject of Spiritbaptism in just three paragraphs under the heading "Water Baptism and the Baptism of the Spirit" within a section which covers various aspects of water baptism. Such a placement of the topic indicates Weber's association of water baptism with reception of the Spirit. He rightly finds a distinction between John's baptism and baptism in Christ, attributing this to the work of the Spirit. The seal of the Holy Spirit Weber identifies with water baptism citing Eph 1:13 and 4:30. While he is definite in regarding baptism as the seal, he allows for some latitude when it comes to the sending and receiving of the Spirit stating that they are "connected to baptism . . . but not bound to it." He further states that the Spirit and baptism are not connected in a way that is sequentially immutable. Perhaps his biggest concession is that "the Spirit cannot be constrained through the celebration of baptism." He is content to say that

sanctification and preservation as fruit of the ongoing operations of the Spirit in the life of the believer. Henry Clarence Thiessen, Lectures in Systematic Theology, rev. ed. Vernon D. Doerksen (Grand Rapids: Eerdmans, 1979), 255-6, states that the "continuing work of the Spirit in the believer" is to fill, guide, empower and teach. In his previous section baptism in the Spirit receives passing mention as a salvific operation. George Eldon Ladd, A Theology of the New Testament (Grand Rapids: Eerdmans, 1974), 488, in a chapter dealing with the new life in Christ explains that the Holy Spirit, who indwells all believers, is active in the lives of Christians in bearing witness to them, assisting in times of weakness and in providing guidance. In a chapter focussing on the Christian life, Ladd states (p. 517-8) that the Spirit's indwelling will manifest itself in conduct, particularly the fruit of the Spirit. Ladd does not think that Paul conceives of the indweling Spirit as "an inner spontaneous power that issues in gradual progress and growth of Christian virtues." Rather, the indwelling Spirit will be evidenced in a new experience of love, freedom and service. Frederick Dale Bruner, A Theology of the Holy Spirit: The Pentecostal Experience and the New Testament Witness (London: Hodder \& Stoughton, 1970), 268, finds that the Spirit "evidences a comprehensive ministry of faith, hope and love" in the lives of believers. For Bruner, the Spirit "once-received" in salvation continues to work in the heart of Christians. James I. Packer, Celebrating the Saving Work of God: The Collected Shorter Writings of J. I. Packer Vol. 1 (Carlisle: Paternoster Press, 1998), 224, outlines the ways New Testament writers have exhibited the "authentic Christian awareness of God." With reference to the Holy Spirit indwelling believers he enumerates five actions thus: (i) to sustain an "understanding of gospel truth," (ii) to remind the individual of their fellowship with Father and Son; to assure that this is a permanent relationship which results in glorification finally, (iii) to respond to the call to suffer with Christ, (iv) to equip individuals for worship and outreach, and (v) to bring realisation of moral weakness and inadequate achievement; to stimulate desire for the Resurrection. Millard J. Erickson, Christian Theology (Grand Rapids: Baker Books, 1983), 888891, in a section entitled "The Continuation of the Christian Life" likewise outlines five roles for the Spirit in the believer, viz. empowering, teaching, intercession, sanctification and bestowal of Spiritual Gifts. Michael Green, I Believe in the Holy Spirit (London: Hodder \& Stoughton, 1975), 76-99, understands that the Spirit's role in the life of the believer is to provide: assurance through signs and sacrament, freedom from self-justification, power to live as a Christian, illumination of God, guidance, and empowerment in prayer. 
baptism is a crucial part of Christian existence, the quintessence of which is the Spirit. $^{12}$

Bloesch, in his Essentials of Evangelical Theology, conflates the pentecostal schema stating that prior to conversion man "must have been breathed upon or baptised by the Holy Spirit."13 The identification of Spiritbaptism with the new birth is clear when the phrase, "The baptism of the Spirit, or the new birth" begins his discussion of baptism by water and Spirit. ${ }^{14}$ However, after a mention of the nineteenth century Holiness movement's doctrine of the second blessing, he makes the concession "that there are blessings of the Spirit beyond conversion and that a relative perfection is attainable in this life." He continues, granting the pentecostal position some validity yet affirming "that the baptism of the Spirit must not be distinguished from the new birth. There is one baptism — into the body of Christ (Gal. 3:27; 1 Cor. 12:13), and this baptism signifies the entrance of the Holy Spirit into our lives. To be 'baptised with the Holy Spirit' is tantamount to 'repentance unto life' (Acts 11:16-18)." It is interesting to note that Bloesch distinguishes being filled with the Spirit from Spirit-baptism, describing the former as "the promise of deeper empowering and further purification," perhaps reflecting an attempt to incorporate empirical knowledge within the Reformed tradition. His earlier discussion (p. 18) highlights the need to go on to be filled with the Spirit having been Spirit-baptised. ${ }^{16}$

Wesleyan theology perhaps opened the way for the pentecostal perspective to emerge in that they definitely have taught and continue to do so,

\footnotetext{
12 Otto Weber, Foundations of Dogmatics, trans. Darrell L. Guder (Grand Rapids: Eerdmans, 1983), 2:601.

${ }_{13}$ Donald Bloesch, Life, Ministry and Hope, 2, Essentials of Evangelical Theology (San Francisco: Harper \& Row, 1978), 7.

${ }_{14}^{14}$ Bloesch, Essentials, 2:11.

${ }^{15}$ Bloesch, Essentials, 2:21-22.
} 
an experience subsequent to conversion called baptism in the Spirit. Where the divergence between the two streams becomes evident is in the respective understanding of what transpires at baptism; Pentecostals generally look for tongues as a sign - if not the central one - of baptism and the bestowal of spiritual gifts, whereas Wesleyans emphasise the "unobtrusive, purifying, and perfecting work" of Spirit-baptism and the "power that makes holiness in conduct possible." In short, Wesleyan teaching is that Spirit-baptism produces entire sanctification. ${ }^{17}$

In 1952 The World and New Zealand carried a series of studies by Joshua McCabe entitled "The Baptism of the Holy Spirit." In one particular article subtitled "The Evidence of the Baptism," McCabe begins by referring to Ephesians $1: 13$ and outlines the opposing position to pentecostal theology, viz. the Ephesians received the baptism of the Holy Spirit when they believed in Christ so determining what is normative today. Guiding the discussion to Acts 19:1-6 McCabe points out that the Holy Spirit came subsequent to belief, and uses the text of Eph 1:13 in the Revised Version (RV) to substantiate that it was "having believed" that they were sealed by the Spirit. ${ }^{18}$ He continues, "the experiences of CONVERSION, and the HOLY SPIRIT BAPTISM, are not synonymous, as some would have us believe."19

\footnotetext{
${ }^{16}$ Bloesch, Essentials, 2:18.

17 A Contemporary Wesleyan Theology, ed. Charles W. Carter (Grand Rapids: Zondervan, Francis Ashbury Press, 1983), 457. See also Donald W. Dayton, Theological Roots of Pentecostalism (Metuchen, N.J: Scarecrow Press, 1987). In the course of examining Pentecostalism's pre-history, Dayton reconstructs (pp. 48-51) the discussion of the 1770s as to whether the Wesleyan "moment" of sanctification could be considered identical to NT Spiritbaptism, and describes (pp. 67-80) how ninety years later the doctrine of Christian perfection flourished in America's revivalist milieu and set the scene (pp. 90-100) for an understanding amongst those in the holiness stream that Spirit-baptism is an instantaneous purifying work subsequent to salvation.

${ }^{18} \mathrm{~J}$. H. Moulton, Grammar of New Testament Greek, $3^{\text {rd }}$ ed. (Edinburgh: T. \& T. Clark, 1908), 130 , refers to $\pi\llcorner\sigma \tau \in u ́ \sigma \alpha \nu \tau \epsilon \varsigma$ as the coincident aorist participle identical in form to that appearing in Acts 19:2 which, he says, is "doctrinally important." Writing at that time McCabe would not have had access to the RSV which renders the phrase thus: "And have believed in him."
} 


\section{Opposition to Pentecostalism}

The validity of subsequence was a continuing theme for the Apostolic Church as many came into the experience of Spirit-baptism in the face of widespread mainstream opposition which marginalised Pentecostalism. ${ }^{20}$ The isolation suffered was due in part to the theological differences existing between Pentecostals and other evangelicals but also to social factors. In particular there was the perception that Pentecostals deviated from the behavioural norm of the evangelical community: not only was what they believed erroneous, but the way they behaved was unacceptable also. In 1961 the New Zealand Baptist took the opportunity to express that denomination's negative appraisal of Pentecostalism in publishing an article by the recently retired principal of NSW Baptist College, the Revd. G. H. Morling. Representative of evangelical sentiment of the day, Morling's composition restricted the exercise of tongues to "an atmosphere of doctrinal error or of unseemly behaviour" and he referred to Pentecostalism in general as having "had unfortunate associations with unseemly extravagance and unhealthy emotionalism." ${ }^{21}$ An Apostolic Church response was forthcoming in the JulyAugust issue of Treasures of Grace that same year. The editorial rejected the Baptist message as incorrect and uninformed stating that Morling's writing was "right out of harmony with much of the contemporary thinking toward the teaching of the pentecostal Baptism and the people who are rejoicing in this experience." ${ }^{22}$ In 1962 New Zealand's touchstone for evangelicalism, the Bible Training Institute, published in its official magazine a two part article by the principal, the Reverend A. L. Burrow, entitled "The Tongues Movement." It

\footnotetext{
${ }^{19}$ McCabe, World 7, no. 4 (1952): 8.

${ }^{20}$ That opposition to pentecostal doctrine was still evident in the early sixties in New Zealand is reported by Worsfold, History, 280.

${ }_{21}^{21}$ G. H. Morling, "Pentecostalism," New Zealand Baptist 77, no. 80 (1961): 142-144.
} 
seems a close correlation in thinking existed between Morling and Burrow, the latter plagiarising a third of his second article directly from Morling. ${ }^{23}$ Again this opinion did not pass without comment by the editor of Treasures of Grace. Dismayed at the appellation "tongues movement" applied by Burrow, the editorial highlighted the solidarity of the three major pentecostal churches in New Zealand, viz. Apostolic, Assemblies of God and Elim, referring to the fact that Spirit-baptism is only one of several articles of faith. ${ }^{24}$ The editor bemoaned that "other evangelicals and orthodox Christians" have been suspicious of Pentecostals, "some going as far as to infer that we and our experience were of the devil." Continuing, the editor expressed frustration at the perpetuation of tales which described pentecostal meetings in terms of wallclimbing and turning somersaults in the dark under diabolic direction. ${ }^{25}$

\footnotetext{
22 J. E. Worsfold, "Baptists and the Pentecostal Baptism," Treasures of Grace 5, no. 4 (1961): 8.

${ }^{23}$ A. L. Burrow, "The Tongues Movement," The Reaper 41, no. 5 (1962): 176-180, 252-255.

${ }^{24}$ The relationship between the Apostolic, AoG and Elim movements has been one of evolution in a positive direction. In the early days of the New Zealand pentecostal scene the Apostolic Church was the strongest numerically, followed at a distance by the AoG; in 1952 Elim had two assemblies. While there was unanimity at a theological level with regard to Spirit-baptism, leaders in the respective denominations were wary of each other and fraternal links between them were not strong. Loyalty to the denomination in which one was introduced to Spirit-baptism was expected, so any transference between movements was felt keenly. Remembering that church membership was much more of a feature in earlier generations, the whole issue of "sheep stealing" was very much in focus. If shifts in allegiance by the rank and file caused difficulties it should come as no surprise that the defection of the former AoG General Secretary C. C. H. Scadden to the Apostolic Church in 1937 caused a major upset. In addition to having held high office in the movement he had also previously been the principal of the AoG Bible School and editor of their national publication, The Evangel. As a result of these poor interdenominational connections, there was little in the way of joint services or other shared use of resources. Interestingly, prior to 1953, Elim ran tarry meetings every Tuesday, but they were poorly attended. This milieu was not conducive to a shared theologising beyond that of a tacit agreement on the truth of Spirit-baptism. Another factor which affected the low level of connection in the formative years was the disfavour shown by both AoG and Elim for the Apostolic Church system of government which was based on the recognition of the New Testament offices of apostle and prophet. The catalyst for improved Apostolic-AoG relations seemed to be the wedding, in 1944, of C. C. H. Scadden's second daughter, Gwen, to AoG missionary Elton Knauf. Scadden was at this stage an apostle in the Apostolic Church; an AoG minister officiated and so the occasion became, essentially, a public statement of cooperative enterprise. Since the 1970s, with the increase in numerical strength of both AoG and Elim, the mutual wariness evident in earlier years has been replaced with an overt cordiality; however, there is still little in the way of joint ventures. Stan Hewitt (first generation member Elim Church, NZ), lan Clarke (former AoG General Secretary), Neil Hetrick (AoG General Secretary), Gwen Knauf, phone interviews by C. M. Worsfold on behalf of Luke Worsfold, Wellington, 2006. Details of attempts at amalgamation of Apostolic, AoG and Elim are contained in the following chapter (fn 77).

${ }_{25}^{25}$ J. E. Worsfold, “The B. T. I. and the Pentecostal Fulness," Treasures 7, no. 1 (1963): 8.
} 
From history it can be stated that wherever there was "enthusiasm," there could be found opposition also. The Catholic Apostolic Church encountered the disapproval of the Anglican Bishop of Wellington at the turn of the century. ${ }^{26}$ However, it was the campaign of Smith Wigglesworth in 1922 that drew some negative public attention; both the clergy and the press criticised Wigglesworth for his teaching and practice, the editors of several newspapers publishing letters for and against the evangelist. ${ }^{27}$ Wigglesworth addressed the Wellington Council of Churches but this served only to widen the gap between Pentecostals and the historic churches, a situation which, according to New Zealand pentecostal historian James Worsfold, continued up until the 1960s. ${ }^{28}$

Former New Zealand Apostolic Church president, Ivor Cullen, recalled that in 1938, as a result of his own recent experience, he attempted to introduce baptism of the Spirit to the Congregational Church where he was attending only to meet with stout resistance. Neither the experience nor those advocating it were wanted, the ensuing ostracisation being immediate and total. At an allchurch meeting, the charismatic protagonists arrived early and sat together but the remainder of the congregation deliberately positioned themselves on the opposite side of the building. Friendships were lost on account of the Congregationalists wanting no association with the charismatically inclined members who had left to attend the Apostolic Church, even to the point of failing to acknowledge them while passing in the street. He recalled that on account of his being an Apostolic Church minister, for many years he received no invitations to attend ministers' fraternals; however the charismatic renewal

\footnotetext{
${ }^{26}$ Proceedings of the $15^{\text {th }}$ Synod of the Diocese of Wellington, (1900), quoted in Worsfold, Charismatic Movements, 68-69.

${ }^{27}$ Worsfold, History, chap. 14 "Crusades and Controversy."

${ }^{28}$ Worsfold, History, 113.
} 
was instrumental in dissolving prejudice and as a result ecumenism developed. ${ }^{29}$

\section{Pentecostal Apologetic}

In the period of opposition the Treasures of Grace editor displayed an unwavering confidence in the legitimacy of the pentecostal experience, the credibility of which he presumably thought to be enhanced by publishing testimonies of important or well-educated people. It seems that the Apostolic Church was not the only movement seeking to validate its witness. In 1961 Treasures of Grace reproduced an item from the Elim Evangel which reported the favourable comments of a well-known Baptist minister from London, Geoffrey R. King, who had attended a pentecostal service in India. That the minister's observation provided authentication, at least in the eyes of the Elim Evangel editor, is obvious from the article's concluding statement: "A few more preachers having a similar experience might persuade them of the reality of the modern Pentecost." ${ }^{30}$ The following year Treasures of Grace carried an article abridged from Herald of Hope which recounted events of a retreat in East Texas under the leadership of a surgeon, a rector and a rabbi. After chronicling the Spirit-baptism of Episcopalians, a Quaker and other evangelicals, the eyewitness account admonished the reader to enjoy the "heavenly baptism." A final note of reassurance sounded, stressing the acceptability of the experience:

Though once thought of as a sort of fanatical outburst peculiar to the Pentecostal or Full Gospel churches, it is now an accepted standard among people of various denominations. I am acquainted with doctors,

\footnotetext{
${ }^{29}$ I. L. Cullen, personal interview, Auckland, 30 September 1996.

30 Treasures 5, no. 4 (1961): 10.
} 
lawyers, teachers, millionaires, and professional people of many areas who have tarried for this power. ${ }^{31}$

Later issues of Treasures of Grace featured reports, reprinted from other publications of pentecostal or charismatic persuasion, ${ }^{32}$ of university students, graduates and well-educated ministers receiving the Spirit. The testimonies of Dr Howard Ervin, noted Baptist scholar; Harald Bredesen, pastor Dutch Reformed Church Mt Vernon, NY; and Dr John Peters, president World Neighbours organisation all appeared in the first issue of $1964 .^{33}$ Perhaps the epitome of analytical scientific practice is the physicist. The testimony, then, of a lecturer in physics receiving the baptism of the Spirit showed that the experience is not only available to those overly susceptible to their emotions. Such a message was amply conveyed in that such a man, well acquainted with the laws governing the interaction of matter and energy, was overpowered by the Spirit of God, spoke an unknown language and thereafter enjoyed a greater sense of His love and presence. ${ }^{34}$ Despite there being a change of editor, the policy of reprinting noteworthy stories continued albeit with reduced frequency. The September-October issue in 1965, for example, carried the testimony of the Anglican priest from the UK, Michael Harper. The charismatic renewal significantly increased the acceptability of pentecostal experience or as one Apostolic minister said, "it used to be Mrs Brown with the twelve children who came into Pentecost, now it is Canon Smith." ${ }^{35}$ Those Pentecostals who approved of and enjoyed the new-found popularity that the charismatic renewal brought initially overlooked the implications for their own theology; popularity is

\footnotetext{
${ }^{31}$ Anna Jean Price, "As It Was in the Beginning (Acts 2-4) Is Now?" Treasures 6, no. 5 (1962): 9.

${ }_{32}$ Apostolic Herald; Trinity Magazine; FGBMFI Voice; Pentecost.

${ }^{33}$ Treasures 8, no. 1 (1964): 10-12.

34 Raymond Shelton, "The Great Psychiatrist," Trinity (1963), abridged in Treasures 8, no. 3 (1964): 5-6. Shelton was identified as an instructor in Physics at Los Angeles Pacific College.

${ }^{35}$ Mrs C. M. Worsfold to W. Luke Worsfold, 28 September 1996, recalling an oft repeated statement of her late husband the Revd. J. E. Worsfold.
} 
achieved far more quickly than synthesis of doctrine. The rise of charismatic theology and its influence on Pentecostalism will be addressed in the following chapter.

This practice of documenting like encounters to build a sense of unity was not a new departure, for throughout the fifties The World and New Zealand featured many Apostolic Church leaders' testimonies of being baptised in the Holy Spirit. Highlighted in the accounts, however, was the common feature of their experience that they "received" when already committed followers of Christ. In some cases it was a sense of wanting something more, a deep personal longing that led to seeking the baptism while for others it was the result of exposure to pentecostal teaching.

Pastor J. D. Eynon, president Apostolic Church, NZ records one of his earliest memories as the "awakening to accept the Lord Jesus Christ as my personal Saviour, at the age of seven." He continues, "a few years later there were stirrings among the Christians of my home town, because it was reported that there was a further blessing of God called the Baptism of the Holy Ghost." $^{\text {"36 }}$ Unlike the church of the 1990s where familiarity with pentecostal expression is widespread even if not accepted, there was a dearth of the relevant teaching in the decades preceding the charismatic renewal. The Apostolic Church considered it a divine mandate to present biblical truth needing to be restored to the church. They had no qualms as regards referring to themselves as vehicles of this restoration of truth - indeed in the hostile ecclesial climate it seems to have been a necessary encouragement.

Pastor M. Goulton, who later became president of the Apostolic Church in NZ recounts: "I was saved in the Apostolic Church, and had been attending for

${ }^{36}$ World 7, no. 4 (1952): 10. 
about three months when I first saw that God had a further blessing for me, and that the Baptism in the Holy Ghost was a gift for all believers." His wife, Ivy Goulton: "I was brought up and confirmed in English Church [sic]. It was through my husband's mother that my family and myself came into contact with the Apostolic Church, where not only did we experience the joys of salvation, but later received the fulness of the Spirit." 37

Pastor Gilbert D. White was originally in the ranks of the hostile opposition believing and preaching that tongues were of the devil. The Whites' interest in the pentecostal baptism was sparked by their attending the revival and divine healing campaign conducted by John $\mathrm{H}$. Hewitt in Perth during September of 1932. They were favourably impressed; however, they noted some theological difficulties and sought clarification with the local Apostolic minister. He tutored them through church doctrines including the baptism of the Spirit, and as a result they began to seek the experience and to attend tarry meetings. It was at one such meeting that Gilbert received his baptism in the Spirit. ${ }^{38}$ He candidly reveals: "I received the blessed Baptism of the Holy Spirit at the very step of the pulpit where, two and half years previously, I had condemned the blessing. Truly the Lord made me eat my words. How gracious He was, and is." ${ }^{39}$

Mrs Alice White remembered that although "my husband and I were saved . . . yet in spite of the spiritual environment of the church we felt a yearning for more, and were convinced that God had something more for us." 40 This yearning had previously exhibited itself in the Whites' association with the

\footnotetext{
37 World 8, no. 1 (1953): 11.

38 J. E. Worsfold, The Reverend Gilbert and Mrs Alice White, The New Zealand Apostolic Pioneer Breviate Series, no. 2 (Wellington: Julian Literature Trust, 1995), 31-33.

${ }^{39}$ World 7, no. 6 (1952): 3-4.

${ }^{40}$ World 7, no. 6 (1952): 4.
} 
Keswick movement. ${ }^{41}$ The opposition to tongue-speaking really belied their disposition towards the higher Christian life otherwise shown in their adherence to Keswickian teaching which promoted holiness and a Spirit-filled life.

Mrs Eynon recalls "looking on wistfully at these happy folk and their rejoicings" with respect to Spirit-baptised believers she had come in contact with until she attended a meeting where she "could wait for the Baptism."42

Pastor J. W. Keane believed himself to be in the company of "thousands of believers" who would respond negatively, as did the Ephesians, to awareness of the Holy Spirit's existence. Because of this lack he explains:

Hitherto my life in the Lord had been an unsatisfied one as far as the real fulness of God was concerned, but THIS, I somehow knew, would complete my joy and soul satisfaction in Him. AND IT DID! One night in 1937, after six months of hungering and thirsting, and by the laying on of the apostle's hands, the Holy Ghost came to stay, and with Him came the satisfying fulness of God. ${ }^{43}$

\section{Apostolic Doctrine}

The terminology "real fulness" is a cognate term to the "full gospel" as perpetuated by leaders in other pentecostal traditions. ${ }^{44}$ On the topic of the "full gospel" Thomas Turnbull referred to the many gifts included therein: "The gift of regeneration, for example, is one of the blessings contained in the Gospel of Jesus Christ." ${ }^{\text {45 }} \mathrm{He}$ is addressing here the perceived problem of the gospel being identified solely with regeneration, hence his promulgation of the full gospel as being comprised of many gifts, of which regeneration is the first. A similar belief, it seems, was shared by Dutch Reformed thinker and Keswick preacher Andrew Murray. In the first chapter of his work, The Spirit of Christ,

\footnotetext{
${ }^{41}$ In 1930 Gilbert was holding the office of Secretary for the Keswick Committee in Kalamunda. Worsfold, White, 28.

${ }^{42}$ World 7, no. 4 (1952): 11.

${ }^{43}$ World 7, no. 5 (1952): 12 .

${ }^{44}$ Notice the sense of permanent indwelling of the Spirit following baptism. This parallels the language of the Spirit being "with" a believer but "in" one who has been Spirit baptised.
} 
he warned of God's children experiencing only "the first half of the promise" (viz. the Spirit given in regeneration) and remaining ignorant of the gift of the Spirit, which is distinguished by the indwelling Spirit revealing the Father and the Son. Murray considered the Spirit's work of conviction leading to repentance and new life as "preparatory" while the "full blessing" was available for claim by Christians who could appreciate the dual nature of the promise. ${ }^{46}$ As Dayton notes, much Keswick teaching was an important conditioner of the ground for Pentecostalism. ${ }^{47}$

An editorial from a 1953 issue of The World and New Zealand encouraged the readers to familiarise themselves with the doctrine and expression of the Baptism, the result being that "it will not be long before you too will seek the fulness with all your heart!"48 A distinction between the "parental love" of John 3:16 and the "bridal love" of Ephesians 5:25 explains the Pauline phrase the fellowship of the mystery, according to an analysis by UK Apostolic pastor Lewis Jenkins, which enabled him to state that Paul here preached the "whole truth." He held that a qualitative difference exists between the love of God the Father for men and the love of Christ for the Church, as is obvious in the statement, "many are enjoying John 3:16, but are not led to the truth of Eph. 5:25." ${ }^{\prime 9}$ In his schema, the initial state apparently served as a preliminary to the subsequent and deeper expression of Christ's love for his own. While the phrase "full gospel" is not used in this article, there is still the

\footnotetext{
${ }^{45}$ Turnbull, The Full Gospel, 5.

${ }^{46}$ Andrew Murray, The Spirit of Christ, rev. ed. (Springdale, PA: Whitaker House, 1984), 6.

${ }^{47}$ Dayton, Roots, 104-108. See below (p. 57) for a brief discussion of third blessing theology. This doctrine was never held in the U.K. so did not feature in the formulation of Apostolic Church doctrine. William K. Kay, Kings College London, agrees that "third blessing theology was not ever held in the U.K." W. K. Kay, email to Luke Worsfold, 29 March 2005. For further information on the third blessing doctrine see Dayton, Roots, 95-100 and Harold Vinson Synan, The Old-Time Power: A History of the Pentecostal-Holiness Church (Franklin Springs, Georgia: Advocate Press, 1973), chapter 5.

${ }_{48}$ World 8, no. 3 (1953): 20.

${ }^{49}$ Lewis Jenkins, "Divine Power, Divine Ability," Riches 12, no. 2, February 1959): 46.
} 
strong sense that an embracing of the "whole truth" brings an experience subsequent to the initial salvific event.

The anti-pentecostal sentiment prevalent at the time is discernible through the apologetic tenor of the testimonies affirming the reality of the experience despite minority status. Pastor C. H. Jourdain recounted, "I was saved in my early youth, praise the Lord, and soon had been baptised in water and was partaking of the Breaking of Bread service. . . . Though conscious of salvation, and glad I was saved, something was missing." He explains how he came to the Apostolic Church and there received his baptism in a display of total commitment to the doctrine regardless of the weight of negative opinion. He states:

Reader, my experience tallies with God's word . . . "Spake with other tongues." (Acts 2;4.) NEVER MIND IF 10,000 PEOPLE OF ALL CREEDS, CHURCHES, OR CHRISTIAN BODIES TRY TO EXPLAIN IT AWAY. . . . THE BIBLE SAYS IT, AND PRAISE GOD, I'VE GOT IT. HALLELUJAH! No critic can stop God giving this experience today to those who hunger and thirst. ${ }^{50}$

T. V. Lewis reported that during the Welsh Revival of 1904-1905 he experienced salvation. Restored after a period of backsliding, he was active in the Congregationalists "but I felt there was a lack in my life, and I did not know what it was." Introduced to teaching on "Baptism of the Holy Ghost," it was his own search which later awakened his interest. He recalls: "I read tracts on the subject, and the testimonies of other men and studied the Bible, until I had an intense longing and thirst for this wonderful blessing." He attended a tarry meeting where he was encouraged by those who laid hands on him to thank the Lord for being saved. Praising the Lord in his native Welsh tongue soon gave way to glossolalia as "torrents of joy and glory filled my soul."

\footnotetext{
${ }^{50}$ World 8, no. 5 (1953): 6, 10.

51 World 8, no. 3 (1953): 4-5. Lewis at the time of writing his account was itinerating through New Zealand as the former president of the Apostolic Church, Great Britain.
} 
Affirming the subsequent nature of the pentecostal experience appeared to diminish in importance in the second half of the 1960s decade with Treasures of Grace publishing only a few personal testimonies of the previously converted receiving the Spirit. ${ }^{52}$ The focus of the accounts was more that of the experience itself, its existence and effect, rather than its occurrence subsequent to salvation. That particular point was made implicitly; for example, Lex Cullen, Apostolic Church missionary to Papua New Guinea, wrote of the occasion when 14 native Christians received the Spirit at an evening service. ${ }^{53}$ In like manner, other articles recounting Spirit-baptisms which occurred at tarry meetings presupposed that it was Christians who were seeking and ultimately filled. On the same page as the previous account, Apostolic Church missionary to PNG, lan Stephenson, removed all doubt concerning the Christian status of one who was filled with the Spirit at a tarry meeting by identifying him as a "probationary deacon." Convinced of the indispensability of Spirit-baptism, Apostolic churchmen saw the reception of the Spirit as almost as significant an encounter as salvation. Remembering that the Christian milieu was less than enthusiastic about Pentecostalism, it is understandable that any case of an established believer receiving the baptism was heralded as an authentication. In 1966, Treasures of Grace printed one such testimony: an elderly man had been a Christian for nearly four decades and, despite sterling service rendered to the Baptist church for the last 21 years, admitted an increasing personal lack of power which brought a hunger for things spiritual. Initially he received a

\footnotetext{
${ }^{52}$ Treasures 11, no. 2 (1967): 12, records the testimony of an attendee at the annual Apostolic Church youth camp, who prior to receiving the Holy Spirit there, had been troubled by an "up and down Christian experience." The accent is more on the need for and seeking process of Spiritbaptism rather than an example of subsequence. Apostolic Life 13, no. 1 (1969): 15, carried the stories of a husband and wife, L. W. and M. Gray, both having been Christians for over thirty years, being baptised in the Spirit. Again the thrust is the keeping power of God, although the refreshing, equipping power of Spirit-baptism was highlighted. With the tone of these articles being the benefit of receiving the maximum from God, presumably they were to serve as an inspiration to those not considered to be experiencing the fulness.
} 
significant blessing at an independent pentecostal cottage meeting but then, after attending Apostolic Church tarry meetings for 16 months, was baptised in the Spirit. That the Apostolic Church thought itself to be an agent in the divine programme of effecting the release of the Holy Spirit and spiritual gifts is evident by the editor's inclusion of the testifier's final comments:

At no time was I approached by any Apostolic person. It was all the Holy Spirit's leading. The Lord has shown me that these things are to be exercised in the Church today. I have seen and heard these gifts in operation, and like Paul I could not be disobedient to the heavenly vision. $^{54}$

The opportunity was not lost to make the point for come-outism in that it was "dishonest to retain my membership and position in the [Baptist] Church and keep attending the Apostolic Church where I was receiving much blessing." An interesting point to note is that among Apostolics there was considerable disquiet over the tendency of mainstream church members who, having come into the experience of Pentecost, preferred to remain in their "respectable" denominations attending charismatic small-group meetings rather than joining a pentecostal church. This sentiment intensified during the later Charismatic Renewal when thousands joined restoration movements within their denominations.

Until 1957 no formal training was available in New Zealand to prospective Apostolic Church ministers; instead, attendance at the Apostolic school in Australia was an option. ${ }^{55}$ Many of the British expatriate ministers had attended the Apostolic Bible school in Penygroes, Wales. Seminaries and secular

\footnotetext{
${ }^{53}$ Treasures 9, no. 5 (1965): 12.

${ }^{54}$ Cyril G. Sandbrook, "My Spiritual Pilgrimage and Recent Encounter with the Holy Spirit," Treasures 10, no. 6 (1966): 12-13.

${ }^{55}$ Turnbull, What God Hath Wrought, 121, writing in 1959 describes the work in New Zealand and includes the statement, "The Bible Training Centre has been opened at Hamilton and has been active for two years, the Principal being Pastor A. L. Greenway."
} 
universities were regarded with suspicion. ${ }^{56}$ However, the council decided that theological education was necessary and formed a training centre in Wellington with senior ministers from the movement constituting the lecturers. The Baptism of the Holy Spirit was covered under a survey of the Church tenets. The lecturer's hand-out notes were brief but to the point. Subsequence is clearly annunciated: "We believe that there is a distinct two-fold work of the Holy Spirit, making a distinction between being BORN of the Spirit and being ANOINTED and BAPTISED with the Holy Spirit. Compare Acts 8:12 (Salvation) with Acts 8:14-17, and Acts 9:3-6 (Salvation) with Acts 9:17."57

There followed quotes from R. A. Torrey which contrast the Spirit's work in regeneration with His impartation of power for service in the Baptism of the Spirit. $^{58}$ Torrey, who was educated at Yale, Leipsic and Erlangen, became principal of Moody Bible Institute, emphasising Spirit-baptism more than his predecessor. Torrey's book, The Baptism With the Holy Spirit, was influential in countering the doctrine that equated Spirit-baptism with the eradication of the sin nature. ${ }^{59}$ He did believe that cleansing from sin was an operation of the Holy Spirit but that such action should not be confused with Spirit-baptism.

\footnotetext{
${ }^{56}$ Paul Grant, one time Apostolic Church minister in Australia recounts: "I was about to leave the headquarters church to begin in pastoral ministry in another State of Australia. I was being briefed and paternally advised by the President of the work. I was a young man of 21 . He encouraged me to spend a lot of time in study of the Bible and prayer, but I was not to attend any night schools or university or do any studies of a secular nature. These could turn me away from what he saw as the only legitimate study, and that was personal reading and research of the Bible and certain, limited devotional books and commentaries. . . I saw it as a sincere expression of the thinking of those early pentecostal days (in the 1940s) that formal theological study and training was a sea of many reefs on which a student could founder, and that in any case, the Holy Spirit Himself was to be seen as our Educator." Letter to W. L. Worsfold, 15 May 1996.

57 J. E. Worsfold, cyclostyled notes entitled "Bible Doctrine with Apostolic Distinctives," lecture no. $5,2$.

${ }^{58}$ Reuben Archer Torrey, What the Bible Teaches (Basingstoke, Hants.: Marshall Morgan and Scott, 1957; reprint, 1986), 271-273.

${ }^{59}$ Dayton, Roots, 103, details four propositions regarding Spirit-baptism that are characteristic of Torrey's writing:

1. There are various designations for Spirit-baptism;

2. The experience is clearly identifiable by the recipient;

3. The experience is distinct from regeneration;

4. The experience has to do with testimony and service.
} 
Instead, Torrey highlighted the "empowering for service" function of the encounter.

A theological stance which separates the Apostolic Church from the pentecostal-holiness stream, such as that prefigured by Andrew Murray, is the belief that Spirit-baptism does not elicit entire sanctification. PentecostalHoliness denominations represent a significant sector of the pentecostal movement that has retained Wesleyan theology in original form, ${ }^{60}$ believing in a "second blessing" crisis of sanctification through a baptism of the Holy Spirit. ${ }^{61}$ This second experience of "Christian perfection" or "entire sanctification" was regarded by the holiness movement as being synonymous with baptism of the Holy Spirit. ${ }^{62}$ In such an encounter the believer is purified of inward sin, that is, the residue attributable to the Fall that remains following conversion. In Wesley's scheme the purity obtained was not "sinless perfection" as such but rather perfect love toward God and man. The possibility of falling into sin remained in this life, freedom from entrapment coming only in the next. However, through the application of discipline, devotion and denial of worldliness, the believer so sanctified could live in victory over $\sin ^{63}$

It was in the 1890s that Wesleyan Methodist preacher Benjamin Hardin Irwin of lowa began to teach a third experience called "the baptism with the

\footnotetext{
${ }^{60}$ Harold Vinson Synan, The Holiness-Pentecostal Movement in the United States (Grand Rapids: Eerdmans, 1971), 162, identified Church of God (Cleveland), Pentecostal Holiness and Church of God in Christ in this category and estimated that these denominations comprised approximately half of the US pentecostal fraternity.

${ }^{61}$ Wesley's crisis experience in Fetter Lane has been regarded by some to be his moment of sanctification and many who had like experience testified to a similar encounter in which they were instantaneously sanctified. See Synan, Movement, 17. W. H. Durham taught that sanctification was included in salvation on account of the "finished work of Christ on Calvary." The necessity of a second work of grace related to sanctification was therefore removed. This teaching resulted in a division amongst Pentecostals which eventually led to the establishment of the Assemblies of God in 1914. Synan, Movement, 147-152.

${ }^{62}$ H. V. Synan, The Old-Time Power: A History of the Pentecostal-Holiness Church (Franklin Springs, Georgia: Advocate Press, 1973), 58, describes the doctrine of the PentecostalHoliness Church of North Carolina and notes that the second blessing experience of sanctification was also known as "holiness", "a pure heart," "perfect love," "moving into Canaan," "the double cure," or "baptism with the Holy Spirit."
} 
Holy Ghost and fire" or simply "the fire." This experience was characterised by exuberant expression including tongues-speaking, trances and jerking physical motions. ${ }^{64}$ Irwin founded what was to become the Fire-Baptized Holiness Church. Their current theology, representative of early American Pentecostalism, is contained in five fundamental beliefs: justification by faith; sanctification as a distinct second work of grace; baptism in the Holy Spirit with the evidence of tongues-speaking; divine healing through the atonement; the imminent premillennial second coming of Christ. ${ }^{65}$ The Church of God (Cleveland) likewise began as a group in the holiness tradition that added the pentecostal baptism. The revival that began in Cherokee County, North Carolina in 1896 was unusual in that some who received sanctification also spoke in tongues at the time when they "prayed through." ${ }^{66}$ To this baptism of fire was added baptisms of dynamite, lyddite and oxidite after the manner of Irwin's teaching. ${ }^{67}$ However, the doctrine of sanctification has remained as a definite crisis experience, distinct from both conversion and Spirit-baptism. Hollenweger notes that the "second work of grace" status of the event was, at the time of his writing in 1969, under some doubt. ${ }^{68}$ Despite this observation, the fourteen point declaration of faith of the Church of God (Cleveland) has as the sixth tenet: "[we believe] in sanctification subsequent to the new birth, through faith in the blood of Christ; through the Word, and by the Holy Ghost." ${ }^{69}$

\footnotetext{
63 Synan, Old Time Power, 18-21.

64 Synan, Old Time Power, 62.

65 This group merged with the Pentecostal-Holiness Church (originally known as the Holiness Church of North Carolina) and later with the Tabernacle Pentecostal Church to form the International Pentecostal Holiness Church. H. V. Synan, "International Pentecostal Holiness Church," Dictionary of Pentecostal and Charismatic Movements, 466-468.

${ }^{66}$ Synan, Movement, 81.

67 Synan, Movement, 82.

68 Walter J. Hollenweger, The Pentecostals: The Charismatic Movement in the Churches (Minneapolis: Augsburg, 1972), 50.

${ }^{69}$ Hollenweger, Pentecostals, 517.
} 
The Apostolic Church places itself in the majority camp of Pentecostalism by not preaching an instantaneous experience of sanctification. In the aforementioned lecture notes this position is stressed:

The Baptism with the Holy Spirit has no direct reference to cleansing from $\sin$. It has to do with the gifts for service rather than graces of character. It is not in itself either an eradication of the carnal nature or cleansing of an impure heart. It is the impartation of supernatural power or gifts in service and sometimes one may have rare gifts by the Spirit's power and few graces. ${ }^{70}$

While it was held that Spirit-baptism did not cleanse an impure heart, a certain level of sanctification was required as prerequisite. Thomas Turnbull believed there to be a minimum of three prerequisites to receiving the baptism of the Holy Spirit, viz. unity, purity and courage. He took the fact that those in the upper room waiting for the baptism were "all of one accord" to imply that relational unity is required. "We must be right with one another," he wrote "as it is only then that the Spirit will descend." He affirmed the necessity of purity stating, "the Holy Spirit can only enter a dwelling that has been prepared by cleansing," supporting his argument with the assumption that in their tarrying the disciples were being purified by God. ${ }^{71}$ Likewise, David Rennie promoted holiness as a precursor to Spirit-baptism. Commenting on both the essential character of baptism in the Spirit and the transformation of human bodies to Divine temples through His indwelling, Rennie then maintains that "first we must be cleansed from sin because God only seals His own property (Ephesians 1:13)."72 One who received the Spirit could then expect a greater ability to live a sanctified life on account of the Spirit henceforth dwelling within.

\footnotetext{
${ }^{70}$ Worsfold, "Distinctives," 2.

71 Turnbull, The Full Gospel, 20.

72 Rennie, Gifts, 20. Nearly thirty years earlier Rennie had preached a sermon at the Apostolic Church convention in Penygroes approaching the theme of Spirit-baptism under the subheadings of "The Promise," "The Preparation," "The Experience."
} 
The understanding, from the time of the Williams brothers, had always been that the Holy Spirit was initially "with" the believer from salvation and then "in" from the time of baptism in the Spirit. However, the recognition that nonpentecostal Christians exhibit sanctified lives led to the concession that evangelical Christians too have the Spirit, i.e. the Holy Spirit is "in" them. This attribution of the Holy Spirit to non-Pentecostals posed the obvious problem of explaining what transpired, pneumatologically, at Spirit-baptism. A solution was found and advanced publicly in the differentiation of the Spirit of Christ from the Holy Spirit. Among those who preached this doctrine were the president J. D. Eynon, the general secretary C. C. Scadden and J. McCabe. It would appear that this doctrine was arrived at by these three independently of each other or of any external influence for that matter; theological insight was believed to be best gained by direct divine inspiration. Certainly in the case of Scadden he received this "revelation" as a result of his own study. ${ }^{73}$ McCabe, in dealing with the claim, based on Rom 8:9, that the Spirit can be received apart from signs following, appealed to the Spirit of Christ/Holy Spirit distinction:

We quote the verse in full: "But ye are not in the flesh, but in the Spirit, if so be that the Spirit of God dwell in you. Now if any man have not the Spirit of Christ he is none of His." . . . To believe we automatically receive the Holy Spirit because we are His is not in accord with other Scriptures. . . . Note in the verse in question that Paul says: "If so be that the Spirit of God dwell in you." Here is a suggestion that the Spirit of God may not be dwelling in them, in the very verse that is used to sustain a false position. The little word "if " shows a condition that may of may not be fulfilled. We suggest that there is a distinction between the expressions "Spirit of God" and "Spirit of Christ."

In support of his argument McCabe cites a translation by A. S. Way of Rom 8:9 which runs: "You, however, are not controlled by your animal nature but by the Spirit of God, if God's Spirit really has its home in you. But if a man has not Messiah's spirit, no follower of Messiah is he." McCabe drew attention

\footnotetext{
${ }^{73}$ Information from his daughter, Mrs G. Knauf Taylor.
} 
to the two terms "Spirit of God" and "Messiah's spirit", noting that the word "spirit" may connote "life", so realising the possibility that one who has the life of Christ may not know "the experience of Holy Spirit baptism."74

C. C. H. Scadden likewise strongly affirmed the separateness of the Holy Spirit and the Son referring to the reception, by believers, of the "spirit of adoption" (Rom 8:15) or the "Spirit of His Son" (Gal 4:6). He constructed an argument on the verses which indicate that the Samaritans who received the Holy Spirit at the hands of Peter and John were already believers, and Paul's declaration that individuals must have the Spirit of Christ (Rom 8:9) in order to be Christian. The consequence of this latter was that those who identify the Holy Spirit with the Spirit of Christ are forced to consider that "a person had not Christ until he received the Holy Spirit??!" - an obviously untenable position to hold. He developed his argument saying that "we cannot receive a measure of the Holy Spirit. He is a Person and a person is wholly received or not at all." Responding to the observation above that some are more Christ-like than others, he admitted that "it seems possible to receive a measure of the Spirit of Christ." Further, it is the Spirit of Christ which bears fruit in the Christian - the Holy Spirit bringing the fruit to maturity. Exposure to years of empirical evidence presumably sourced the comment that "the manifestation and exercise of the Holy Spirit does not always make better Christians, but manifestation and exercise of the Spirit of Christ does."

This position was examined by UK pastors Rowe and Dawson whilst in New Zealand (circa 1940) giving it their approval. Locally, however, it found opposition in the person of Pastor White who managed to rally some support against the doctrine. White's counter action had little effect on the movement

\footnotetext{
${ }^{74}$ McCabe, "The Spirit-Filled Life," typewritten article held by Mrs G. Knauf-Taylor.
} 
nationally as there had always been a range of teaching given in Apostolic pulpits and such a view would have been considered just another variation. Several other individuals within the movement preached the "Spirit of Christ" doctrine for a season but it was never widely held. ${ }^{76}$

It was the expressed hope, even an expectation, on the part of church leaders that converts would deepen in their spiritual life progressing from water baptism to Spirit-baptism, enabling them to "thus know more abundantly the joy of salvation." ${ }^{, 77}$ An address by J. Purnell to the Penygroes annual convention, in 1929 encouraged the hearers to seek the baptism of the Spirit because "we can never know Jesus as we ought to know Him apart from receiving the Holy Spirit." This statement he later repeats without the qualifier "as we ought to know Him" which, with this alteration, almost lends itself towards a saved-onlyif-Spirit-baptised meaning. Purnell in his sermon indicated that when Jesus Christ comes into an individual, living waters flow out in evidence. This is a Christ-likeness in the convert and is "God's gift to the believer." It seems here that there is no separation envisaged between the conversion and the evidence, which harmonises with the salvation/Spirit-baptism dyad inferred earlier. The theology is not clear cut however, Purnell returning to a more usual acknowledgement of a two-stage pentecostal process by stating: "The first determines your eternal destiny; if you reject Him, you are for ever lost. The second determines your position in the Church of Jesus."78

\footnotetext{
${ }^{75}$ Cecil Charles Haddon Scadden, "The Spirit of Christ and the Holy Spirit," Bible-study notes supplied by Mrs G. Knauf Taylor.

${ }^{76}$ F. A. F. Bongers, Being Conformed to His Image (n. p., 1964), 8, outlines something of the doctrine, stating that "what we actually received at conversion is the life of Jesus, the Spirit of Christ, not the Holy Ghost as some teach." Bongers further distinguished (p. 9) the "fruit of the Spirit" mentioned in Gal 5:22 as that coming from the Spirit of Christ not the Holy Spirit. He cites (p. 22) the opinion of J. N. Darby that rebirth and being sealed and anointed with the Holy Spirit are distinct experiences; in this he returns to the core pentecostal belief.

77 Water baptismal service report of the annual convention, Penygroes, in Riches 1, no. 8 (1919): 19.

78 Jacob Purnell, "God's Perfect Gifts," Riches 6, no. 6 (1931): 245-246.
} 
What is clear however is that "the baptism," as first and second generation Pentecostals referred to the experience, was considered indispensable to the normal Christian life. Innumerable benefits followed; for example, the baptism brought the ability to receive new light on Scripture, ventured one preacher, new light obtainable in no other way - those not Spirit-baptised being unable to comprehend truths thus revealed. ${ }^{79}$ In the reasoning of the first generation Apostolic church leaders it was a given that the promise was available to every disciple so there appeared no excuse for unSpirit-baptised Christians. If such a state existed it was argued that it was the fault of the individual. ${ }^{80}$

The passage of time has not seen this view shift appreciably. Over twenty years later in an article on the "Holy Spirit and the Body of Christ," Thomas Turnbull affirmed that "there is no doubt that God intended this baptism to be the experience of every Christian." ${ }^{11}$ An article written by Rennie for the Riches of Grace in 1959 was reprinted without alteration by the magazine in 1977, affirming that the baptism in the Holy Spirit "can and should be the experience of every regenerate, open-hearted seeker after God." He conceded the plausibility of the doctrine which advances total Spirit reception at conversion but notes that practically this is not the case with the majority of Christians. He

Certainly Purnell is here looking for believers to realise their full potential as Spirit-equipped members in the church of Jesus. But he is also reinforcing a hierarchy in the church--one based on the level of spiritual endowment. This is perhaps more evident in the remainder of his sermon where he speaks of God giving to the church the gift of Christ as head who in turn "gave men for the church" in various offices representative of his character, viz. apostles, prophets, evangelists, pastors and teachers. Purnell thus underscores the principle of authority in the church.

${ }^{79}$ F. Warburton, "The Church of Christ," a sermon delivered to the annual convention, Penygroes 1937, published in Riches 13, no. 1 (1937): 201.

${ }^{80}$ T. C. Matthews, "Concerning the gift of the Holy Spirit," Riches 14, no. 6 (1939): 440.

At first glance it might appear that it was a similar attitude that arose years later in the WordFaith movement with regard to realising God's promises. The doctrine promoted by such figures as Hagin and Copeland outlines that faith can claim promises from God and that any failure to receive is not on the divine side but due to insufficient faith of the claimant. The sovereignty of God in such a scheme is severely undermined. This, however, does not appear to be the extent to which the Apostolic forefathers went; rather, they were concerned at the possibility of people closing their eyes to the truth and passing up a readily available blessing.

${ }^{81}$ T. N. Turnbull, "The Holy Spirit and the Body of Christ," Riches 14 (July 1961): 219. 
supports this empirical argument by the comment that "we have no authority from Scripture to expect that it must or even that it should be so." ${ }^{82}$

The Penygroes Convention of 1944 supplies more indicators of the prevailing theology. Harold Miles, at the time pastor of London's Peniel Chapel, brought a sermon on the parable of the ten virgins. He affirmed that believers necessarily have a measure of the Spirit. His own baptism in the Spirit he referred to as the Lord giving him a "double portion" of the Spirit. An obvious theme of the address is the need for Christians always to have sufficient oil as exemplified by the wise virgins. The Holy Spirit, not being transferable, needs to be sought by each one on his own behalf. Bringing his message to a climax Miles noted that while the foolish virgins went to buy oil, the bridegroom came. He said:

I want to be wise. I am not going to say that only those that are baptised in the Holy Ghost will be caught up to meet the Bridegroom. I do not say that, but the power of the Holy Ghost will help the Church to prepare for the coming of the Bridegroom, and your and my need is to be filled and kept filled with the Spirit of God. ${ }^{83}$

The implication is clear: being Spirit-baptised and remaining full of the Spirit renders one qualified to meet the Lord. That Miles could allude to the exclusivity of Spirit-baptised Christians in relation to the Second Coming possibly reflects the acceptance this view had at the time. His admission "I want to be wise" indicates what he would perhaps like to have said and thus signals his inclination towards this belief. ${ }^{84}$

Apostolic Church missionary to Papua New Guniea, H. M. Reah, believed that on account of the indigenous people's difficulty in following the separated

\footnotetext{
${ }^{82}$ D. T. Rennie, "Our Heritage Pentecostal," Riches 12, no. 2 (1959) reprinted with the same title in Riches 1, no. 3 (1977).

${ }^{83}$ Harold Miles, "The Parable of the Ten Virgins," The Enduring Word: A Report of the Apostolic Church International Convention 5-13 August 1944, p. 186.
} 
life, it was more prudent to gradually unfold the truth of Spirit-baptism. His approach entailed leading converts in three stages, viz. justification, sanctification and baptism of the Holy Spirit. Reah acknowledged the blessing of justification by faith but added that God expects believers to "go on" and be "preserved from spiritual stagnation." This advancement to the second and third stages was not so readily grasped. He observed that many Christians accept the Spirit's work in salvation but balk at the concept of a second work of grace. While not precluding the possibility of an experience of sanctification as part of Holy Spirit baptism, Reah found that most Christians must "enter separately into the two blessings." 85

The 1970s saw no marked deviation from the "necessity of Spirit-baptism" view. W. W. Pearson contributed an article to Apostolic Life where he identified four necessary components of the early church as being: belief in the Bible; Christ-centredness; Spirit-filling; and dedication to witness. Referring to the coming of the Spirit upon individuals he wrote that they can then "function as a vital member of the Body of Christ." The inference here is that one's activity in the body is retarded without the fulness of the Spirit. ${ }^{86}$ Apostolic Life reprinted a Bob Mumford article on Christian warfare which outlined as the necessary foundation for the Christian life, first faith in Christ, then waterbaptism, and lastly baptism in the Holy Spirit. The believer who experienced these three components thus achieved "ground level" status. It is obvious that

\footnotetext{
${ }^{84}$ There is also the question of intended audience effect. The milieu of war-time Europe perhaps created fertile ground for references to the Second Coming, allowing Miles to encourage believers to be suitably equipped to meet the future.

${ }^{85}$ H. M. Reah, "Holiness and Power," Treasures 7, no. 6 (1963): 10-11.

${ }^{86}$ W. W. Pearson, "A Pertinent Question: Do We Possess the Answers?" Apostolic Life 15, nos. 1-2 (1971): 6-8.
} 
Mumford regards baptism in water and Spirit, following salvation, to be the absolute minimum in Christian experience. ${ }^{87}$

The May 1963 issue of Riches of Grace printed an article on the topic of Spirit-baptism in which the distinction was made between the Spirit being "with" and "in" an individual. Based on the John 14:17 text, where Jesus assures the disciples that the Holy Spirit "dwells with you and shall be in you," it was believed that the baptism of the Spirit afforded the means whereby the Spirit would inhabit a believer who hitherto had only enjoyed the Spirit's accompanying presence. This particular article unpacks little of the doctrine, in fact quite the opposite - it almost needs to be inferred. The only explanation of the Johannine text is: "The Holy Spirit is the Father's gift; even as the Son was God's gift to the world. Thus the Holy Spirit is the gift of the Father to those who receive the Son. He is 'with' them in order to be 'in' them." 88 The bulk of the article treats the precursors and the necessity of the baptism, recapitulating the preconditions of obedience, unity and perseverance. ${ }^{89}$

In the 1950s the joint official organ of the Apostolic Churches in New Zealand and Australia was Herald of Grace. The November 1952 issue was devoted entirely to the topic of Spirit-baptism and the first article, by the coeditor R. Longstaff-Wright, outlined what the baptism in the Holy Spirit is. The various operations of the Spirit were mentioned, categorising His action as either "with" or "upon" or "in". An immersion in the Spirit meant "that henceforth the Holy Spirit is your environment" in contrast to the special but limited anointings of individuals prior to the Ascension. On account of the Father's

\footnotetext{
${ }^{87}$ Bob Mumford, "Flesh or Demons," reprinted from New Wine (1973) in Apostolic Life 20, no. 1 (1977): 8-11, 22-23.

88 C. C. Ireson, "The Holy Spirit Baptism," in the series "Truths Relating to the Holy Spirit," Riches 16 (May 1963): 137.
} 
benevolence (Lk 11:13) the Spirit is available to all, Jesus promising the disciples that he would make representation for them to receive the Spirit "as an abiding presence; furthermore, the Holy Spirit would not only be with them but IN them (John 14:16-17)." ${ }^{90}$

The ability of the believer to continue Jesus' mission on Earth was dependent on a personal reception of the Spirit who, according to LongstaffWright, is freely and comprehensively available. A strong premillennial understanding of end-time schema contributed to the sense of immediacy felt and perpetuated by Apostolic followers: Jesus sent the Spirit simply to enable disciples to work until his imminent return. It is to this emphasis that we now turn our attention.

\section{Premillennialism}

Consistent with the premillennial doctrine, Pentecostalism of the Depression era saw in the prevailing world situation early warning of a future total collapse. A school leaver, predicted one Apostolic writer in 1935, could not be confident of being able to "engage in normal occupation this side of the Millennial Age." Teaching that promised improvement in the world was repudiated; rather, the universal condition was believed to mark the "beginning of sorrows" mentioned in Mt 24:7. ${ }^{91}$ In 1935 the memory of the Great War was still quite fresh, only three years had passed since the Russian famine, the world-wide 'flu epidemic had claimed 22 million by 1920, an earthquake in Kansu Province, China the same year killed 200,000 and the employment

\footnotetext{
${ }^{89}$ The precondition of purity, characteristic of the formulations of others, is not entirely absent here. In discussing the unity of the disciples in the upper room the writer stated that "they were separated from the world without." Ireson, "Baptism," 138.

90 R. Longstaff-Wright, "What Is the Baptism In the Holy Spirit?" Herald of Grace 12, no. 3 (1952): 50 .

${ }^{9}$ A. E. Gay, "The Coming Collapse," Revival Echoes (November 1935): 114.
} 
difficulties associated with the Depression were expected to rise. Added to this, Nazism was on the increase - the Nuremberg Laws becoming effective in 1935. For a premillennialist in 1935 the world events of the previous 15 years provided ample fulfilment of the Matthean text, further justifying an expectation of an imminent world end.

The Apostolic Church, from the beginning has embraced premillennialism and at various stages fostered a heightened expectation in the end of the age. UK pioneer pastor to Australia, William Cathcart, preached a sermon at the Apostolic Church, Adelaide in 1934 entitled "The Coming Age-End Climax." Basing his sign-of-the-times assessment on the relationship of Israel to other countries, he pronounced that the end of the age was imminent. He reasoned that if the next international conflict was to be Armageddon then there was some possibility of the Anti-Christ already being in the world. ${ }^{92}$

In the 1960s there appeared to be a re-emphasis of the "last days" nature of the times. Norman White, in a 1961 issue of Treasures of Grace, wrote of "Satan's last desperate effort" to veil truth from humanity. ${ }^{93}$ The tension felt by the rest of the world in the US-Cuban crisis of 1963 prompted the Apostolic Church national Sunday school superintendent to raise the possibility of world devastation resulting from an exchange of atomic missiles. ${ }^{94}$

The Australian Apostolic evangelist and pastor, Murray Cameron, was the keynote speaker at the NZ Apostolic Church annual Easter convention of 1970. He brought a message stressing the immediacy of the parousia, suggesting that before the year's end "the Trumpet of God may well have sounded." His mention of the end-time was without analysis of world events and served to

\footnotetext{
${ }^{92}$ W. Cathcart, "The Coming Age-End Climax," Revival Echoes (March 1935): 189,192-195.

${ }^{93}$ N. W. White, "Last Day Sign Ministry," Treasures 5, no. 4 (1961): 9.

${ }^{94}$ A. V. Arnold, "Could There Be World Tragedy in 1963," Treasures 7, no. 1 (1963): 14.
} 
motivate the believer to witness and effect salvation to the world. ${ }^{95}$ By contrast, Alistair Gardiner, another Australian Apostolic Church minister, engaged in the study of: world events, advances in technology and predictions of secular academics, all measured against relevant Scripture texts in an attempt to determine the extent to which biblical prophecy was being fulfilled. Apostolic Life published such a column by Gardiner from November 1971 - December 1972.

A pre-tribulation position proposes an advent unannounced by the trials of a seven year period, which adds to the sense of imminence associated with the Lord's return. During the 1960s there was a surge of interest in the pretribulational view at the popular level, primarily through Hal Lindsey's publications. The pentecostal disposition towards pretribulationism can possibly be traced to Edward Irving in the 19 th century ${ }^{96}$. In the early 1970 s there was considerable concern amongst prospective university students who attended the Apostolic Church, Wellington, regarding the irrelevance of secular education in the face of a rapidly approaching end-time. The contention was that the remaining days should be spent either at Bible college or immediately evangelising the world. ${ }^{97}$ Representative of the many end-time slogans of the day is the quote from Archbishop Richard Trent in Apostolic Life October 1972, "The second advent is possible any day, impossible no day."

Interpreting sections of Ezekiel, Daniel and Revelation futuristically enabled Gardiner, while addressing a NZ Apostolic ministers' seminar in 1973, to state that the true church was about to pass through the open door of

\footnotetext{
${ }^{95}$ M. D. Cameron, "Let the Trumpet Sound," Apostolic Life 14, no.1 (1970): 3-5.

${ }^{96}$ Evangelical Dictionary of Theology, 1984 ed., s. v. "Rapture of the Church," by R. G. Clouse.

${ }^{97}$ D. E. Thirkell to W. L. Worsfold, 26 October 1996.

${ }^{98}$ In the same issue the editor conveyed the instantaneous unheralded nature of the rapture thus: "Every living Christian will suddenly disappear. They will go up from hospital beds,
} 
Revelation 3:8. He impressed upon his hearers that "we are living in the last days, the time when we are about to go up." 99 The August Apostolic Life later that year attributed the Christian love and unity displayed in ecumenical evangelism to a last-day outpouring of the Holy Spirit. ${ }^{100}$ In the same issue president of Global Evangelistic Missions Bill Blessman wrote that it was a period of extraordinary end-time harvesting of souls. ${ }^{101}$ The Charismatic Renewal, along with its ramifications for ecumenism, signalled to many the drawing to a close of this age. In essence, the two articles referenced above reflected a positive response to the Renewal, the writers seeking to not only encourage Pentecostals to embrace their charismatic brethren but to give themselves wholeheartedly to the task of evangelism, given the lateness of the hour.

From the mid-1970s the end-time focus dissipated, there being no further articles of that nature in the NZ periodical. This is perhaps also due to the nature of the publication changing in the late 1980s from a doctrinal magazine treating theology to a newspaper covering events. However, the UK publication Riches of Grace, still widely read at the time in NZ, carried two articles in 1985 on the topic of end-times. Veteran minister of the UK Apostolic Church Ian Macpherson outlined the viability of the premillennial stance and without any specific endorsement explained the correspondence made by some theologians between God's rest from creation (Gen 2:2) and the millennial Sabbath. This schema points to AD 2000 as inaugurating the seventh millennium and therefore the reign of Christ on Earth. Macpherson avoided endorsing this position outright and instead pointed to the agreement some

automobiles, airplanes, ships, workshops, streets, fields, houses, everywhere and from every nation." R. G. Lee, "Return and Reign of Jesus Christ," Apostolic Life 16, no. 4 (1972): 5.

${ }_{99}$ A. Gardiner, "Present-Day Fulfilment of Bible Prophecy," Apostolic Life 17, no. 3 (1973): 22.

${ }^{100}$ E. J. Guerin, "Editorial," Apostolic Life 17, no. 2 (1973): 1. 
would find with Hal Lindsey in predicting the return of Christ prior to this century's end. ${ }^{102}$ The magazine's editor, Frank Parker, contributed the second article in which he outlined the signs which would mark the Lord's coming but reassured the reader that "before disaster strikes, Jesus will come!" To reinforce the impending nature of the Second Coming Parker included this quote from a prophecy given at a UK Apostolic Church convention earlier in the year: "You are living in the last of the last days!"103 There was a clear sense of urgency with regard to evangelism due to this perception that time had all but expired.

The enduement of power resulting from a personal descent of the Spirit was seen as the only adequate requisite for carrying out this commission to evangelise. Pretribulational Premillenialism governed pentecostal thought on the Christian's role within society; with the end of the age just around the corner it meant that there was little interest expressed in social action or in otherwise affecting the community, especially in the political realm. ${ }^{104}$ The most effective use a Spirit-filled Christian could make of the time available was to engage in evangelistic endeavour which meant, in this context, witnessing to the unconverted, presenting the gospel in kerygmatic form.

Not only was "soul-winning" the recommended activity, it was the expected. Reminiscent of war-time posters rousing patriotic interest in military service, Australian evangelist Cameron wrote that God "needs you."105 The prevailing mood was one of there being a definite purpose to God's action of saving and filling people with his Spirit in that all such people were called to be

\footnotetext{
${ }^{101}$ B. Blessman, "What in the World is God Doing?" Apostolic Life 17, no. 3 (1973): 5.

102 I. MacPherson, "Good News for Bad Times," Riches 1, no. 1 (1985): 3-6.

103 F. Parker, It's Later than You Think," Riches 1, no. 8 (1985): 120-121.

104 Harvey Cox, Fire from Heaven: The Rise of Pentecostal Spirituality and the Reshaping of Religion in the Twenty-first Century (Reading, Massachusetts: Addison-Wesley, 1995), 288-9,
} 
part of the Divine task. Evangelistic fervour has not abated any in the Apostolic Church; however, it must be conceded that in many cases the motive power for this function is not so much the impending end of the age and consequent loss of opportunity to effect salvations, but rather the growth potential of the local church. $^{106}$

Commentators approaching Pentecostalism with an understanding of sociological aspects have noted that the movement's beginnings were inauspicious in terms of the social standing of its practitioners and adherents. ${ }^{107}$ The message of Azusa Street provided solace and destiny not only for the financially impoverished but for African Americans suffering the indignity of racism. While racial subjugation was not a catalyst for the growth of New Zealand Pentecostalism, the state of the nation in general provided fertile ground for a similar response to that exhibited in the United States. It would, however, be a misrepresentation to imply that the New Zealand Apostolic Church emerged with a "storefront" image, although there were few wealthy or tertiary trained persons in membership in its early years. During the 1930 s trades and working-class people were predominant; post World-War II, the balance shifted more in favour of the trades and from the 1970s the church's demographics reflected that of the general population. In comparison to the historic churches, Apostolic congregations tended to have lower representation from the higher socio-economic groups. ${ }^{108}$

This observation correlates well with the demographic analysis included in Rayner's 1980 sociological study of the Christchurch Apostolic Church. Results

in tracing the shift in perspective of Pat Robertson on this point, observes that for Pentecostals at Azusa Street this was precisely their stance. See also Blumhofer, Restoring the Faith, 17.

${ }^{105}$ Cameron, "Trumpet," 5.

106 See article by A. V. Arnold, "Priorities," Apostolic News (August 1996): 5, which indicated that the ethos of Apostolic Church NZ is church growth/planting.

${ }^{107}$ Blumhofer, Restoring the Faith, 12; Cox, Fire, 4, 86. 
showed that the trade and technical certifications were the norm for those members of the congregation over the age of 30 , whereas the high school certificate enabling entry to university, viz. "University Entrance," was the most commonly earned academic achievement in younger members. There were few in the congregation in managerial or professional occupations; however, $20 \%$ were identified as students indicating the potential to increase the number in these two categories in later years. At that time, "homemaker" and "school teacher" were listed as the most common occupations. ${ }^{109}$

Drawing on earlier work of American sociologists, Rayner discusses the motivation of individuals to join pentecostal groups. ${ }^{110}$ Turner and Killian, writing on collective behaviour, found that the participation in a social movement provides "the personal gratifications of group membership" which is otherwise lacking in isolated individuals. ${ }^{111}$ When applied to pentecostalism, the corollary is that individuals suffering a sense of deprivation have their needs fulfilled through belonging to the movement. ${ }^{112}$ Rayner also mentions Turner and Killian's discussion of "personal status movements" - those societies which assure their members the advantages of "greater success or recognition" within the movement, or provide the rationale for "reinterpreting their own position" in society at large. ${ }^{113}$ Religious movements reorient their members by redefining the "individual's value scheme," substituting new reference groups, which hold

\footnotetext{
${ }^{108}$ E. H. Hendery, personal interview, Auckland, 16 November 1995.

109 Pauline Anne Rayner, "Social Characteristics of Pentecostalism: a Sociological Study of the Christchurch Apostolic Church" (MA thesis, University of Canterbury, 1980), 47-49.

${ }_{110}$ Rayner, Social Characterisitics of Pentecostalism, 14-16.

${ }^{111}$ Ralph H. Turner and Lewis M. Killian, Collective Behavior (Englewood Cliffs, N. J.: PrenticeHall, 1957), 432.

112 Stephen Hunt establishes a link between pentecostalism and deprivation stating, "At a macro-sociological level, the movement would seem to deal with a wide range of deprivations, but mostly those of an economic nature or related to status in its various social manifestations." Stephen J. Hunt, "Deprivation and Western Pentecostalism Revisited: The Case of 'Classical' Pentecostalism" PentecoStudies 1, no. 1 (2002): 26.

${ }^{113}$ Turner and Killian, Collective Behavior, 409.
} 
new values, for the old. ${ }^{114}$ Turner and Killian include an excerpt from Anton Boisen's 1939 essay subtitled, "A Study of the Holy Rollers," wherein he describes how members of pentecostal groups are given a new world in which to reorient themselves, replacing the frustrating larger world with a gratifying smaller one. ${ }^{115}$

Rayner notes that neo-pentecostalism saw the introduction of middleclass people to charismatic phenomena and that social science investigations of pentecostalism thereafter became more sympathetic, an example being the study by University of Minnesota anthropologists Luther Gerlach and Virginia Hine. While it is apparent that these two researchers did not find deprivation to be the sole or even the prime reason for individuals joining pentecostal movements, ${ }^{116}$ their thoughts on "personal access to power" are not dissimilar to observations above concerning member benefits of pentecostal groups. Specifically, "any 'Spirit-filled' Christian, layman or pastor, can preach the word of God effectively" and individuals have "access to the source of spiritual power, wisdom, and authority."117

In summary then, we can say that the deprived and uneducated were attracted, as they are today, by Pentecostalism's message of millennial hope; as Lewis Smedes has ably demonstrated, a hope-filled future favourably affects

\footnotetext{
114 Turner and Killian, Collective Behavior, 414-415.

${ }^{115}$ Anton T. Boisen, "Economic Distress and Religious Experience: A Study of the Holy Rollers" in Turner and Killian, Collective Behavior, 415-420. Boisen writes (p. 417):

To be brought face to face with God is then the experience of feeling oneself brought into that fellowship which is for the individual all-important. And inasmuch as the entire personality organization and its existing scale of values is a social product and the reflection of a particular social group, so to feel oneself identified with a superior fellowship means inevitably a new social reference. It means also a new conception of oneself and a thorough-going re-organization of values.

${ }^{116}$ Luther P. Gerlach and Virginia H. Hine, People, Power, Change: Movements of Social

Transformation (Indianapolis: Bobbs-Merrill, 1970), 82.

117 Gerlach and Hine, People, Power, Change, 42. Later (pp. 163-164) in an analysis of movement ideology, one of the characteristics outlined is the concept of personal power coupled with a reliance on God. The result is that the individual is contolled by God, removing the sense of personal responsibility.
} 
the present. ${ }^{118}$ The indigent were able to endure hardship believing that they would be more than compensated in the New Jerusalem. Baptism in the Spirit enabled these early seekers a taste of the future heavenly kingdom through the mystical experiences of tongues-speaking, visions, trances, healings and prophecy. Millennialism correlates an increase in activity of the Holy Spirit with the close of the age so that as the incidence of these signs and wonders increased, so did the expectation for the dawning of the new Heaven and new Earth.

\section{Tarrying}

A corollary of the subsequence doctrine is the necessity of "tarrying." The word "tarry" in the KJV translates $\kappa \alpha \theta$ í $\alpha \alpha \epsilon$ (lit. "sit") the imperative in Jesus' instruction to the disciples with respect to their ensuing encounter with the Spirit (Lk 24:49). ${ }^{119}$ The period of waiting which preceded the disciples' reception of the Spirit provided the rationale for the expectation that some form of seeking over time was requisite for this baptism. It was not that time per se was the effective element, rather what transpired in the individual during the interval.

Preparation by the believer for the baptism of the Spirit was widely taught albeit with some variation apparent in the details. W. A. C. Rowe acknowledged that while the baptism of the Holy Spirit was a gift of grace, there existed certain conditions which if not met could "stay the giving hand of the Lord." Over and above the requirements of repentance and water baptism, Rowe saw the need for a greater level of faith and for the "principle of restitution" both toward man and God to be developed in the seeker. He

${ }^{118}$ Lewis B. Smedes, "Hope: The Power, The Pain, And The Passion," Fuller Focus 4, no. 2 (1995): 10. 
affirmed the effectiveness of these processes, referring to many who had addressed these issues and subsequently come into the experience of the Spirit. $^{120}$ Rowe added the general conditions of "ardent desire" and "persistent seeking" but noted that the whole process need not necessarily take long. ${ }^{121}$

The trio of "absolute surrender," "active faith," and "accurate obedience" were offered as essential precursors to receiving the Spirit by E. H. Williams, British Apostolic missionary to the Cameroons. The surrender mentioned was not that of the individual to the will of God but rather of a more complete nature, entailing the release of pride and its associated fears. The active faith was one that would grow into actual receiving while the accurate obedience required "tarrying until." He endorsed the notion of personal cleansing as a harbinger to Spirit-baptism encouraging seekers to "clear out the rubbish! Then, you will feel no embarrassment as the HOLY ONE comes to abide with you for ever." For Williams, restricting the action of tarrying to organised meetings was insufficient, producing a frustration in the seeker not envisaged by God; the times of corporate seeking were simply an aid to an individual's private quest. ${ }^{122}$ Opportunity to tarry for the gift was, however, generally provided through the organised "tarry meeting." The Hutt district report to the Wellington area

119 The NKJV retains "tarry"; however, other contemporary translations have: "stay" (RSV, NASB, NIV); "must wait" (TEV); "must stay" (CEV); "stay here" (NEB); "Don't begin telling others yet--stay here" (LB).

${ }_{120}$ William A. C. Rowe, The Pattern of Pentecost (n. p., n. d.), 26-27. Cf. comments by Turnbull, Full Gospel, 20, in which he outlines as prerequisites to Spirit reception: unity, purity and courage.

${ }^{121}$ Rowe, Pattern, 27; 29.

A discussion on the theological function of tarrying follows in chapter four. However, the preliminary point can be made here that the preparations are in fact responses of the heart after the manner of those required for salvation: faith, repentance and confession are all responses required of the individual for salvation. So, as opposed to describing "conditions" that need to be fulfilled through tarrying, it is possible to speak, along with Rodman Williams, of the "context" in which the Spirit is given. The context is the human situation of faith being exercised toward the goal of receiving the Spirit. That is, preparations undertaken in tarrying are expressions of faith. The several activities and attitudes which appear in teaching on tarrying may be considered as appropriate for any earnest Christian wanting more of God. For more on Rodman Williams' use of "context" in place of "conditions" see his Renewal Theology: Salvation, the Holy Spirit and Christian Living (Grand Rapids: Zondervan Publishing House), 294.

${ }^{122}$ E. H. Williams, "Have Ye Received?" Treasures 7, no. 4 (1963): 10-11. 
apostles' and pastors' meeting of September 1950 records that "several" tarry meetings had occurred in the previous six months. The five members seeking the baptism had not at that time received but had not suffered any loss of enthusiasm for the experience; consequently, the report proposed to increase the frequency of the meetings. ${ }^{123}$

To Rowe it was self-evident that prayer was carried out by the disciples who tarried in Jerusalem, suggesting the description for that period to be the "great pre-Pentecost prayer meeting." McCabe in a Treasures article where he constructed a scenario of the upper room in which earnest prayer from a people who "know God" was offered. ${ }^{125}$ Generally, tarry meetings were not considered to be the sole means of receiving the baptism; however, the process inherent in tarrying was a common denominator in all who "came through" in the baptism. It was conceded that tarrying was not necessarily required for God's plan to be fulfilled, ${ }^{126}$ but the validity of the exercise was found in the fact that God had ordained it. ${ }^{127}$

The doctrine of tarrying presumes that various "conditions" must be met in the seeker before the gift is bestowed. This is evident from the frequent treatment of the topic in sermons and articles up until the late 1960s. An article by McCabe in 1953 drew an analogy between the setting in order in the Tabernacle and in the Temple before the coming cloud, and the setting in order in an individual's life before the Spirit's advent: "Having searched your heart and your life, and having set each thing in order, 'continue,' as the word 'tarry'

\footnotetext{
${ }^{123}$ Minutes of the Wellington Area Apostles' \& Pastors' Meeting held at Hastings, 18 September 1950, p. 15. It is interesting to note that the publication The Apostolic Church: Its Principles And Practices (Penygroes: Apostolic Publications, 1937) in the chapter on Spirit-baptism states (p. 200): "The local presbytery should be on the alert and see that provision is made for regular tarrying meetings."

${ }_{124}$ Rowe, Pattern, 32.

${ }^{125}$ McCabe, The Baptism of the Holy Ghost: What Is It All About?" Treasures 7, no. 3 (1952): 8.

126 "The Pentecostal Promise (The filling of the Spirit)," Riches 13, no.6 (1960): 179.
} 
means, until you are filled."128 Possibly McCabe drew the cloud/spirit analogy from an editorial by the movement's founder, D. P. Williams, in a 1938 issue of Riches of Grace. There Williams, writing on believers being human temples for God, stated: "In the Baptism of the Spirit the cloud overshadows the Temple." He suggested that separation and surrender would assist those desiring to be filled with the Holy Spirit. ${ }^{129}$

"The oil follows the blood!" is how D. T. Rennie at the Penygroes annual convention in 1939 described the sequence of cleansing then anointing. He outlined four stages in the preparation process as: cleansing from sin; consecration of life; compliance with the Divine will; concentration of desire. The similarity of this schema with others is hidden in the alliteration: consecration of life he explained as surrender, compliance with the Divine will as obedience and concentration of desire as asking with persistence. ${ }^{130}$ Some thirteen years later the pattern had altered little, C. Morgan putting forward in an article the steps of cleansing, consecration and asking. ${ }^{131}$

Tarrying was not a passive pastime, it was an earnest business. T. V. Lewis at the 1938 Penygroes convention gave his own testimony of seeking for the baptism pointing to the strength of desire he had for the blessing prior to receiving it. He recounted spending "hours on my knees with a thirst and a longing for the Baptism." Lewis made reference to Luke 9:13 and stated: "It is all in the asking." ${ }^{132}$ J. D. Brownlie, speaking on baptism in the Spirit at the same convention, emphasised the importance of persistent asking associated

${ }^{127}$ C. C. Ireson, "Truths Relating to the Holy Spirit: The Holy Spirit Baptism," Riches 16 (May 1963): 138.

${ }^{128}$ McCabe, "The Baptism of The Holy Spirit: How To Receive Your Baptism," World 8, no. 1 (1953): 8.

${ }^{29}$ D. P. Williams, "Human Temples For God," Riches 13, no. 3 (1938): 305-308.

130 D. T. Rennie, "The Baptism in the Holy Spirit," Floods Upon The Dry Ground: Being A Report Of The Apostolic Church International Convention, Penygroes 5-13 August 1939 (pp. 46-48).

${ }^{131}$ C. Morgan, "How Is The Baptism Of The Holy Spirit Received?" Herald of Grace 12, no. 3 (1952): 64-66. 
with the tarrying process ${ }^{133}$ and on an earlier occasion promised: "As you persistently seek this baptism with your heart fully surrendered, God will meet you and will baptise you with His Holy Spirit."134

Much later, T. N. Turnbull, also in the UK, advanced a four-point scheme of preparation for the baptism: asking, waiting, thirsting and humbling of the seeker before God. Elaborating on this last he wrote: "Personal cleansing must precede this blessing," finding as a basis for his argument Peter's admonition in Acts 2:38 to repent, be water baptised and receive the Holy Spirit. ${ }^{135}$ Endorsement for the teaching of preparation was found in the writings of the Reverend A. A. Boddy, vicar of All Saint's, Monkwearmouth, Sunderland, during the early 1900s. In 1962 Riches of Grace published a letter Boddy had sent to a colleague in which he had set down some "simple rules for those seeking their Pentecost." The first condition to be fulfilled was a witness from God of a clean heart because, it was reasoned, the Spirit cannot enter an unclean abode. What remained for the seeker to do was to stand on the promise of being cleansed then ask God for the power. ${ }^{136}$

This theology of requisite personal cleansing is reflected in the hymns sung at tarry meetings. One such song began: "Here from the world we turn, Jesus to seek," the second verse expressing the element of thirst with the words: "Now in our longing hearts graciously shine!" The remainder of the hymn aroused the expectation that the descent of "mighty power!" would be accompanied with an overwhelming sense of heavenly joy in the sacred

\footnotetext{
${ }^{132}$ T. V. Lewis, "The Baptism Of The Holy Ghost," Riches 14, no. 1 (1938): 80.

133 J. D. Brownlie, "The Promise Of The Father: The Coming Of The Holy Ghost and Fire," Riches 14, no. 1 (1938): 227.

${ }^{134}$ Brownlie, "Apollos And His Converts," Riches 11, no. 1 (1935): 110.

${ }^{135}$ Turnbull, "The Deity and Personality of The Holy Spirit: The Preparation and Expectation of The Holy Spirit," Riches 14 (March 1961): 91.

${ }^{136}$ A. A. Boddy, excerpt of letter sent to Mr Rowson, reproduced in Riches 15 (December 1962): 382-383.
} 
moment. ${ }^{137}$ These tarry meeting hymns were not only expressions of emotion - particularly desire - but theological statements which outlined the processes involved in tarrying. Consider these words by J. W. Chapman:

Oh, ye that are thirsting for fulness

Make room by forsaking all sin

Surrender to Him your whole nature

By faith let the Spirit come in. ${ }^{138}$

It is apparent from the lines of the following verse that the seekers possessed hope that the conditions of holiness and consecration that they tried to fulfil in order to obtain the gift of the Spirit would be finally realised in Spiritbaptism itself:

Spirit of purity and grace,

Our weakness pitying see:

O make our heart Thy dwelling place

And worthier Thee ${ }^{139}$

Tarry meetings were a regular part of church life up until the late 1960s. Apostolic missionary to New Hebrides Paul Grant furnished a report published late 1962 in Treasures of Grace in which he refers to planned "waiting meetings." This was in response to renewed emphasis at the time of the need for Spirit baptism. The association of conditions with baptism is evident in Grant's thought when he writes of "rising concern for right pure relationships with Christ and others, and a burden for holiness living, notably among the young people." Such consecration was preparatory to receiving the Spirit, Grant pointing to the resulting opportunity given God to provide blessing, power and a spiritual dynamic not previously known by those receiving. Equivalence

${ }^{137}$ Fanny J. Crosby, "Here From The World We Turn," Redemption Hymnal (London: Elim Publishing House, 1951), \# 73. Information on hymns sung supplied by Mrs G. Knauf Taylor.

${ }^{138} \mathrm{~J}$. W. Chapman, "Holy Spirit, Come In!" Redemption Songs, \# 837.

${ }^{139}$ Harriet Auber, "Our Blest Redeemer, Ere He Breathed," Redemption Hymnal, \# 206. 
of this experience with a glossolalic baptism is apparent with Grant stating: "All that accompanies this speaking in tongues proves that it is of God."140

Conventions, where attendance far exceeded that of a local congregation, generally included tarry meetings in the programme. At the 1947 Christmas camp convention at Napier, New Zealand, "waiting meetings" were held prior to some of the night services, the result being two people on successive evenings receiving "a glorious baptism in the Holy Spirit, with signs following." 141 Penygroes conventions often combined tarry and healing meetings; for instance during the 1967 convention there were three such meetings in which 20 were baptised in the Spirit and 11 healed, some of major disabilities.

"Waiting meeting" is a cognate term for "tarry meeting" although J. D. Thompson, NZ general superintendent during the 1930s, believed there to be a distinction between the two. As chairman of the All Officers' Meeting, held in Wellington in 1938, he maintained that there was a difference between tarrying for the baptism, and a waiting meeting in which individuals could receive a "deeper filling." In his thinking the first type of meeting should be conducted for a few at a time, whereas the second could encompass the whole assembly. Tarry meetings at the time were presumably noisy affairs, the chairman commenting that "a tarry meeting is not the time to make merely a noise."

The recollection of J. Guerin, senior Apostolic minister in NZ, was that the tarry meeting followed a definite pattern and was characterised by noise and praise. This pattern was one of Scripture reading, praise including singing of hymns, and personal encouragement or tutoring while the seeker was waiting for the "break through." Generally the tutoring would simply be an admonition to "let go brother" or "press in." If reception was not forthcoming then it was

\footnotetext{
${ }^{140}$ P. E. Grant, "The Work of the Holy Spirit in the New Hebrides," Treasures 6, no. 6 (1962): 12.

${ }^{141}$ World 1, no. 1 (1947): 5.
} 
assumed something in the seeker's life was a blockage to the Spirit's flow or else it was not God's timing. Either way, further preparation was called for. Guerin recalls Apostolic founding father in New Zealand D. L. Greenway suggesting to one Janet Collins that the wearing of make-up was hindering her reception. $^{143}$ These descriptions comport well with that given by pentecostal historian James Worsfold in the second of his NZ Apostolic pioneer biographies:

"Tarry" or "Waiting" meetings, where Christian seekers spent long seasons of prayer on bended knee for the promise of the baptism of the Holy Spirit for believers, were the order of the day. Formally recognised leaders, both men and women, would often move round the prayer-room, offering prayers and encouragement and laying hands on the seekers' heads. Many of these meetings produced rather high levels of noise as people prayed loudly at times and gave triumphant shouts of praise. Because the leaders were particular about the Scriptural injunction that women should have their heads covered when offering prayer, any hats which fell off were gently replaced by the leaders! ${ }^{144}$

Rowe's Pattern included a section entitled "The Conduct Of The Tarry Meeting." With the purpose of such a meeting being to seek the Lord rather than "His matchless Gift," it was incumbent upon the leader to create the appropriate atmosphere in the opening song or prayer. It was expected that a passage of Scripture relating to the gift of the Spirit would be read along with an explanation of the text. At this point those assembled would "settle themselves before the Lord" to seek him individually. Rowe reminded his readers that it is the exalted Christ who sends the pentecostal blessing; in drawing attention to the identification of the "Enthroned Christ" with the "Crucified Christ" he proved that the relationship of seekers to the Lord is through the blood of Christ.

\footnotetext{
${ }_{142}^{14}$ Minutes of All Officers' Meeting, City Temple, Wellington, 16 April 1938, pp. 8-10.

143 J. Guerin, interview with W. L. Worsfold, Waiuru, Saturday 24 August 1996.

144 Worsfold, White, 32-33. Here Worsfold also recalls that the sound associated with a tarry meeting was often called "God's noise" and that it had the potential to have an off-putting effect on some observers.
} 
Focusing on the blood would bring believers into a humble state recognising the extremes of unworthiness and grace. ${ }^{145}$

In the contrast between the liturgy of the "nominal Church services" and the freedom exhibited in the Welsh Revival, where whole congregations would pray simultaneously out loud, Rowe found reason to encourage concert prayer and praise, each individual contributing as they felt prompted by the Spirit. The practice of tutoring received mention, Rowe defining the need for the leader to be aware of seekers who might be in need of comfort, restraint or assistance and to effectively minister as required. With regard to the tutoring, strong opposition was expressed to employing any technique of humanly inducing glossalalia, be it through imitation, exercise of rapid natural speech or compliance with a ban on natural speech. ${ }^{146}$

Rowe diverted from the task of explaining the conduct of the tarry meeting to defend its existence against unnamed proponents of the "modern technique" who advocated reception of the Spirit without tarrying. He then concluded his treatment of the mechanics of the tarry meeting with a word on posture. He conceded that physical posture is of little value; rather, it is the spirit which is all important. Yet he came down on the side of Apostolic tradition when he stated, with respect to prayer and seeking, that "there is nothing more Biblical, more honouring, more acceptable, nor more convenient for the purpose than being upon one's knees." ${ }^{147}$

An action associated with tarrying is the laying on of hands. Rowe, again reacting to "modernistic teaching," made reference to the dangers of what he termed "indiscriminate" laying on of hands on those seeking the baptism. He preferred to follow the example in Acts where "with one exception . . . it was

\footnotetext{
${ }^{145}$ Rowe, Pattern, 38-39.

${ }^{146}$ Rowe, Pattern, 40-42.
} 
always the Apostles who laid on hands for the Baptism of the Holy Ghost," Rowe extending this privilege to include other "divinely appointed functions . . . such as Pastors and Elders." Warning was given concerning the possibility of a seeker receiving of the spirit of the one ministering; it was therefore important to be sure that the minister carried the "influence of divine appointment." On the other side of the exercise the minister needed confirmation of a seeker's salvation and spiritual condition before hands were to be laid on, Rowe finding support for this in Paul's caution to Timothy to "lay hands suddenly on no man (I Tim 5:22)."148

The present analysis shows that tarrying for the Spirit was not considered to be simply a matter of waiting until God decided to bestow the blessing. Instead there was a process of tarrying which involved both the individual and the church - to some extent the reception of the gift being mediated through its officers. The effort on the part of the seeker centred on the preparation, that of the church officers on guidance and exercise of spiritual authority. It is belief in subsequence that permits the doctrine of tarrying. Reciprocally, the process involved in tarrying substantiates the case for a second work of the Spirit which goes beyond conversion and prepares the recipient for witness. For this enduement of power it was the believer's privilege, even duty, to "tarry."

\section{Summary}

Considering the weight accorded to prophetic utterance by the Apostolic Church, the ratification via prophecy in 1932 of the practice of tarrying for the power ${ }^{149}$ shows the importance that the subsequence doctrine carried for the movement. It was primarily the notion of subsequence that drew the ire of

\footnotetext{
${ }^{147}$ Rowe, Pattern, 45-50.

${ }^{148}$ Rowe, Pattern, 52-54.
} 
mainstream Christianity; however, the Pentecostal's mode of conduct also contributed to the strong opposition voiced against them. ${ }^{150}$ This negative sentiment, sometimes publicly expressed, forced a definite sense of common purpose amongst the early Apostolic Church members. A significant feature in the generation of this "camaraderie" was the sharing of personal testimony. Initially these testimonies sought to substantiate the doctrine of subsequence, but over time the emphasis turned more to the actual experience and its transforming effect.

The Apostolic Church has from its inception taught that Spirit-baptism is to equip the believer for service. Millennialism, prevalent in the movement up until the mid-1970s, provided the appropriate environment for the outworking of this qualification rendered by the Spirit; increased power for witness would see the end-time harvest reaped. Evangelism, still high on the agenda, is no longer exclusively motivated by a sense of an imminent world end but simply by an urge to expand the church.

With respect to emphasis, it can be said that originally the Apostolic Church boldly profiled the practice and preaching of tarrying; however, the last two decades have seen this profile become non-existent. The following chapter will treat the reasons for this and make some initial comments pertaining to the effect such a shift has had on the movement. Certainly in the period of its popularity, tarrying promoted rigorous attempts at personal holiness and wholehearted seeking after God. It seems that tarrying operated at two levels on the church; the theological component argued for a body of believers thoroughly consecrated, striving for purity before receiving the gift of the Spirit, while the

\footnotetext{
${ }^{149}$ See note 6 above.

150 The Apostolic Church faced a further challenge in that their revelation of apostolic and prophetic offices was not appreciated even by other pentecostal denominations.
} 
practise of tarrying provided an environment suitably conducive to a seeker receiving the Spirit. 


\section{CHAPTER THREE}

\section{CRITIQUE OF SUBSEQUENCE}

This chapter proposes to critique the Apostolic Church New Zealand's teachings on subsequence, examining the following influences on the doctrine during these periods:
$1930-1950$
Tarrying
$1950-1970$
Latter Rain
1970 - Present
Charismatic Movement

\section{An Issue of Theology}

The Apostolic Church theology of subsequence is based on the hermeneutic that assumes that the apostolic experiences recorded in Acts are normative for Christians today. ${ }^{1}$ Pentecostal theologian Gordon Fee criticised this practice of translating "descriptive history . . . into normative experience," raising the important question of how does one distinguish between narrative statements which should be taken as normative and those which should not. The solution he offered is that the author's intent determines whether the narrative is to have normative value. ${ }^{2}$ Robert Menzies however, believes that

\footnotetext{
${ }^{1}$ The editorial of Riches of Grace 7, no. 5 (1983): 67, entitled "A Valid Pentecostal Experience" referred to the biblical accounts of the pentecostal baptism as the "divine proto-type." The word "pattern" appeared frequently in discussions on the method of receiving the Spirit, one particular publication (earlier quoted) taking the title "The Pattern of Pentecost."

2 Gordon D. Fee, "Hermeneutics and Historical Precedent - A Major Problem in Pentecostal Hermeneutics" in Russell P. Spittler, ed., Perspectives on the New Pentecostalism (Grand Rapids, MI: Baker Book House, 1976), 121, 126. See also Fee's article "Baptism in the Holy Spirit: The Issue of Separability and Subsequence" in Pneuma 7, no. 2 (1985): 90, in which he cautions against elevating repeatable patterns found in Scripture to the level of "mandatory."
} 
Luke's intent is to teach a Spirit-baptism distinct from conversion for the purpose of empowerment. This he bases on his analysis of Luke, who he says "never attributes soteriological functions to the Spirit." Rather, according to Menzies, Luke "describes the gift of the Spirit exclusively in charismatic (or more specifically, prophetic) terms as the source of power for effective witness."3 Menzies' position has been viewed as an extreme, failing to appreciate the soteriological work of the Spirit in Luke's understanding. ${ }^{4}$ Menzies' work has however, drawn attention to Luke as a bona fide theologian.

Fee concedes that the Samaritan Pentecost does provide a biblical precedent for subsequence but queries (p. 91) whether "this single precedent [is] the intended divine pattern?"

${ }^{3}$ Robert P. Menzies, Empowered for Witness: The Spirit in Luke-Acts, Journal of Pentecostal Theology Supplement Series, ed. John C. Thomas, Rick D. Moore, Steven J. Land, no. 6 (Sheffield: Sheffield Academic Press, 1994), 237-238.

In Empowered Menzies interacts with Gordon Fee's Gospel and Spirit: Issues in New Testament Hermeneutics (Peabody, MA: Hendrickson, 1991); however, it is James Dunn's Baptism in the Holy Spirit: A Re-examination of the New Testament Teaching on the Gift of the Spirit in Relation to Pentecostalism Today (London: SCM Press, 1970) that provided the original basis for the ongoing pentecostal-evangelical dialogue. The October 1993 issue of Journal of Pentecostal Theology published the response of Dunn to some of the ensuing pentecostal scholarship in Luke-Acts viz. that of: Roger Stronstad, The Charismatic Theology of St Luke (Peabody, MA: Hendrickson, 1984); James B. Shelton, Mighty in Word and Deed: The Role of the Holy Spirit in Luke-Acts (Peabody, MA: Hendrickson, 1991) and Menzies' earlier version of Empowered published as The Development of Early Christian Pneumatology with Special Reference to Luke-Acts (JSNT sup, 54; Sheffield; JSOT Press, 1991). Later issues of JPT carried replies by Menzies, Shelton and a response by William Atkinson. Atkinson, by profession a pastor, has provided useful summaries and critiques of Dunn's respondents in JPT 6 (1995), although on occasions it appears that he has tried a little too hard to give the definitive assessment.

To review Dunn's thesis: the gift of the Spirit is the peak of conversion-initiation and not an experience subsequent to it. Dunn states in the introduction to Baptism, 4, that the term "Christian" could only be applied to those who had "received the Spirit." Dunn finds his conclusions especially supported in Rom 8:9, 14; Gal 3:2, 3; Jn 4:14; 7:37-9; 20:22. The earliest response to Dunn was Stronstad's Theology. He claims (p. 10) that Dunn reads Paul's use of the term "baptised in the Holy Spirit" into that of Luke. Stronstad finds particular fault with Dunn's exegesis of Acts $2: 4 ; 8: 16 ; 19: 3$. The pentecostal outpouring is vocational as was Jesus' anointing at Jordan. Stronstad believes that Dunn has overemphasised the initiatory aspect of Jordan and therefore does not share the latter's view that the baptism initiated Jesus into the new age and covenant (p. 62). Stronstad holds that both the Samaritans and Ephesians were already Christians; therefore, the Spirit was a missionary endowment (pp. 64, 90).

Menzies, Empowered, also disagrees with Dunn over the latter's argument that Jesus' anointing initiated him into the messianic age, citing as evidence the Jewish expectation of prophecy characterising the messianic age. Menzies questions the level of association that Dunn assumes between Pentecost and Sinai. Therefore, for Menzies, the descent of the Spirit does not indicate the inauguration of a new covenant (pp. 189-201). In the case of Cornelius' conversion Dunn equates the granting of the "Gentiles repentance unto life" (Acts 11:18b) with the "same gift" (Acts11:17a). He also finds the "purifying their hearts by faith" (Acts 15:9) a synonym for "giving them the Holy Spirit" (Acts 15:8). Menzies however, disputes these findings, noting that the reception of the Spirit was the evidence upon which the pronouncement could be made that they were forgiven (pp. 215-218). Like Stronstad, Menzies assumes the Ephesian disciples to be Christian (pp. 218-225). 
If it is accepted that Luke intended to promote a work of the Spirit distinct from salvation then the validity of patterning contemporary Christian experience on the Acts texts is affirmed. However, the early Apostolics were sometimes guilty of reading back into the text their own presuppositions. In promoting the subsequent nature of Spirit-baptism British Apostolic minister C. H. Rosser demonstrated some strained exegesis finding supporting evidence for the doctrine in Ephesians 5:26: the washing of water by the word he took to be the action of Scripture to "convince, convict and convert" in a process preparatory to the Spirit's indwelling. ${ }^{5}$ There is little basis for assuming that "word" here means "Scripture." For biblical writers the term "word of God" meant the message of God, that is, the words given by God to speak; words preserved in written form in the Bible. Hence the popular equation of the term "Word" with Scripture. In this instance however, $\varepsilon v$ ' $\rho \eta \mu \alpha \tau$ is not likely to mean "the gospel" (even less likely to connote "Scripture"), appearing as it does without any

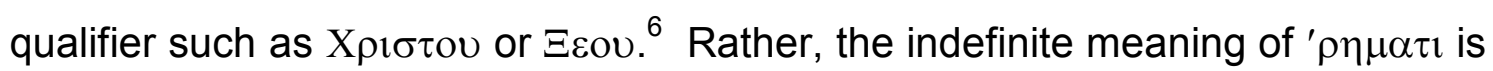
here clarified by the preceding reference to baptism. This verse is better understood as referring to a church set apart for Christ, or sanctified, and made

Shelton, Mighty,173, does not consider Jordan to be the inauguration of a new age. With regard to Pentecost Shelton gives an example of Dunn's reading Paul into Luke in the apparent conversion of the disciples in Lk 24. Shelton proposes that Paul's intent is to describe Christian living whereas Luke shows the power for witness (p.128). The Christian status of Paul prior to Ananias' prayer is presumed (p. 131) but in the Gentile and Ephesian cases Shelton points to an ambiguity because the soteriological aspect of the Spirit's work was not Luke's primary interest (pp. 131-135).

${ }^{5}$ C. H. Rosser, "The Church and its Mission" Riches 15, (October 1962): 306.

${ }^{6}$ See T. K. Abbott, A Critical and Exegetical Commentary on the Epistles To The Ephesians And To The Colossians The International Critical Commentary, ed. S. R. Driver, A. Plummer, C. A. Briggs (Edinburgh: T \& T Clark, 1979), 168. If the less preferred translation of ' $\rho \eta \mu \alpha \tau \imath$ as "Word of God" is followed (so Living Bible), it is allowable to deduce that purification characteristic of regeneration is a result of the action of Scripture on an individual, even though Paul is here referring to the church as a whole. However, to derive from the cleansing operation of Scripture a preliminarising function vis á vis the coming of the Spirit surely moves outside the intended meaning of the text. 
ready for Christ by the cleansing of water baptism; the spoken word being of great importance in this rite $^{7}$

\section{"With" / "In" Schema}

In the previous chapter we noted that the explanation offered by the Apostolic Church of the Spirit's activity at salvation and Spirit-baptism was that He was first "with" believers and then "in" them. Longstaff-Wright reinforced this schema in the 1952 article quoted earlier; however, in the same work he blurred the with/in distinction giving the preposition "with" the opposite meaning by combining it with the verb "filled." Referring to the day of Pentecost, he put forward that the "disciples were immersed IN and filled WITH the Holy Spirit at the same time." 8 For the sake of clarity he would have done better to have contrasted the phrases "be with" and "filled with" thereby using the verbs be and filled to identify the respective terms: salvation (with) and Spirit-baptism (in). A real difficulty was that none of the writers on this topic made clear precisely in what manner they understood the Spirit to be "with" a believer. They have not said what "with" means. ${ }^{9}$

The picture is not overly enhanced by the explanation contained in Fundamentals, the official statement of the Church's tenets. In the section covering Spirit-baptism the prepositions "in", "for", "within" and "upon" are all used to describe the various actions of the Spirit with respect to an individual. The distinctions made are at best unhelpful: to differentiate between the Spirit

\footnotetext{
${ }^{7}$ Several options present as to the meaning of the term $\varepsilon v$ ' $\rho \eta \mu \alpha \tau$ :

(i) the gospel preached leading to baptism;

(ii) the baptismal formula;

(iii) the preaching at the baptism;

(iv) spoken witness of a converted baptismal candidate.

${ }^{8}$ R. Longstaff-Wright, "What Is the Baptism In the Holy Spirit?" Herald of Grace 12, no. 3 (1952): 50.

${ }^{9}$ This quite probably indicates insider assumptions: the authors assumed their readers knew what the normative experience entailed and so failed to clearly define terms.
} 
dwelling "in" and working "within" a person is entirely arbitrary. Consistent with established Church doctrine there was a clear resolution of the dual actions: being born of and baptised in the Spirit. However, the entry concludes by noting that, biblically speaking, the Holy Spirit can be "in" and "upon" believers. It is left for the reader to work out whether these prepositions (in, upon) both refer to Spirit-baptism or if they relate to the preceding contrast of salvation and baptism in the Spirit respectively. ${ }^{10}$

A meditation which appeared on the covers of a 1951 issue of The World and New Zealand presented a variation of the "with" then "in" theology. The Spirit comes to dwell within the believer, the writer said, and referred to the opportunity to then be filled with the Spirit. The distinction between the two actions was made thus: "He comes within us; we come within Him."11 His coming "within us" was identified with the indwelling presence of the Lord in salvation while our coming "within Him" was defined as baptism or immersion in the Holy Spirit. Given that the "with" then "in" schema was the official stance of the Apostolic Church in Great Britain and New Zealand up until the 1960s, this contribution by the organising editor is possibly an attempt to resolve the theological awkwardness resulting from the church's reticence to recognise the internalisation of the Spirit in salvation. It is a weak attempt however, in effect merely positing a reciprocity which from the human side is largely devoid of meaning.

The Apostolic Church was not alone in appealing to the "with" / "in" explanation; the Assemblies of God also, used the John 14:16-17 text to

\footnotetext{
${ }^{10}$ The wording appears thus: "The receiving of the Spirit Himself by a person (so that the Spirit dwell [sic] in that person) is distinguished from any work done by the Spirit for or within that person (John 14:17). So that to believe in Christ and be born of the Spirit, is not the same thing as to be baptized in the Spirit (Acts 8:6, 14-17). The Scriptures speak of the Holy Spirit as being "in" us (John 14:17); and "upon" us (Acts 1:8). Those baptized in the Spirit realize this." Fundamentals (Bradford: Apostolic Publications, n.d.), 18.
} 
differentiate between the Spirit's action in regeneration and the pentecostal baptism. An Assemblies of God minister in the United States, Willis Blossom, in his 1918 publication $^{12}$ took issue with Scofield's position on I Corinthians 6:19 that all believers are indwelt by the Spirit. ${ }^{13}$ Blossom pointed to the Samaritan and Ephesian disciples as evidence that the Spirit was obviously not received at conversion. Not all Christians enjoy the same level of experience as the Corinthians of whom Paul spoke as having received the Holy Spirit. This position denies that John 20:22 refers to the disciples receiving the Spirit; instead the promise of Jesus is realised on the Day of Pentecost. Therefore in this system, the disciples only had the Spirit with them, as opposed to in them.

J. E. Stiles, a Methodist minister who later became credentialed with the Assemblies of God in the United States, states in the first chapter in his book on Spirit baptism that, "Jesus made a difference between the Spirit being WITH people and IN them." Stiles does not explicate the theology of the Spirit's proximity versus indwelling, but he does refer to an increase in quality and intensity in the believer's relationship with the Spirit for those who take "this further step." ${ }^{14}$ Ralph M. Riggs, general superintendent of the Assemblies of God in the United States during the fifties, did more than simply quote Jn 14:17 as an explanation, attempting instead to unravel the "mystery" of the Spirit's relative action in Old Testament prophets, the disciples and New Testament believers. The mystery for Riggs was that, according to Nehemiah 9:30 and I Peter 1:11, the Spirit was in the prophets and, on the strength of Galatians 4:6, also in New Testament believers. The anomaly arises in that the Spirit was, by

\footnotetext{
${ }^{11}$ Iris Sutherland, World and New Zealand 5, no. 1(1951): back cover.

${ }^{12}$ Willis Blossom, The Gift of the Holy Spirit, rev. ed. (Madison, Wisconsin: n.p., 1925), 128130 , interacts with Scofield.

${ }^{13}$ Cyrus I. Scofield, Plain Papers on the Holy Spirit (New York: Fleming H. Revell, 1899), 43.

${ }^{14}$ J. E. Stiles, The Gift of the Holy Spirit (Glendale, CA: The Church Press, Farson \& Sons, n.d.), 7.
} 
logical necessity, only with the disciples because Christ was constrained in a physical body during his earthly ministry. The resurrection and subsequent glorification of Christ rendered it possible for him to be in them, John 20:22 being the "first step of the Spirit's incoming," the consummation of John 14:17 occurring on the Day of Pentecost. ${ }^{15}$ There follows in Riggs' short treatment of the topic a quote from Hopkin's work, Law of Liberty, which also sees the filling with the Spirit at Pentecost as the completion of the events of John 20:22 where "the Holy Ghost had actually been given to the disciples, that Christ breathed upon them the Holy Ghost." ${ }^{\text {16 }}$ It seems, particularly through the inclusion of the Hopkin quote, that Riggs has employed the notion of the Spirit coming upon as an intermediate step between his dwelling with then in the disciples. Riggs' treatment, albeit brief, is by far the most cogent of those prevalent at the time.

It is interesting to note that the "with" / "in" schema was used by an Evangelical and Reformed Church pastor in Ohio, Victor Paul Wierwille. In a short book entitled, Receiving the Holy Spirit Today, Wierville devotes one chapter to the receiving process, reminding the reader that in response to spiritual hunger and in order to provide spiritual abilities the Spirit will not only "be with you . . but in you."

Germane to this exploration is the question of the extent to which other writers, particularly Assemblies of God, influenced the thinking of Apostolic ministers. It has been earlier stated that Apostolic ministers originally were expected to source their insights by personal study of the Bible, perhaps with the assistance of a minimum of reference tools; the study of theology in itself

\footnotetext{
${ }^{15}$ Ralph M. Riggs, The Spirit Himself (Springfield, MO: Gospel Publishing House, 1949), 45.

${ }^{16}$ Riggs has used J. Elder Cumming, Through the Eternal Spirit (Drummond Tract Depot, London: 1937), 78, as his source for Hopkin's quote. No other publication details of Hopkin's work have been cited by Riggs, presumably because they are lacking in Cumming's writing.
} 
was not encouraged. However, some individuals established personal libraries that included many American, and therefore non-Apostolic, writers, so it can be assumed that Apostolic doctrine was not entirely developed in a theological vacuum. $^{18}$

Rennie, writing in 1967 to address the need for instruction within the Apostolic Church on spiritual gifts, begins his study by discussing the Gift of the Spirit. $^{19}$ Here he states that it was insufficient for the disciples to have the Spirit with them and quotes Jesus' promise recorded in John 14:17. The fulfilment of this promise on the Day of Pentecost Rennie refers to as the "personal infilling of one hundred and twenty obedient believers." ${ }^{20}$ However, he then deviates from the usual schema and attributes to biblical phrases normally taken to be synonymous with each other, different shades of meaning to describe what he calls "different phases" of the experience. He delineates thus: "Baptized in refers to the initial incoming: He in us, we in Him. Filled with describes the continuous indwelling. Coming upon signifies the power anointing. Sealed with reminds us to whom we belong." 21

After briefly referring to the initial evidence of receiving the Spirit and the necessity of the overall experience the author reinforces the above quoted progression stating: "His initial incoming ushers in His gracious indwelling and makes possible our complete infilling." ${ }^{22}$ It would seem that Rennie has misapplied his own terminology by referring to the experience of the 120 as "infilling" when the word "incoming" would have been more consistent. Rennie's work commissioned as it was by the Apostolic Church (UK) and completed in

\footnotetext{
${ }^{17}$ Victor Paul Wierwille, Receiving the Holy Spirit Today (Van Wert, OH: The Way, 1957), 67.

${ }^{18}$ The fact that the names of Brumback, Canty, Ervin, Gee, Frodsham, Holdcroft, Horton, Riggs Stiles, Wierwille, to name a few, were found on the shelves of NZ Apostolic President J. E. Worsfold underscores this.

${ }^{19}$ Rennie, Gifts, chap 2.

${ }^{20}$ Rennie, Gifts, 18-19.
} 
1967, points to the "with" / "in" schema being officially adhered to well into the late sixties.

Proponents of the "with" / "in" position did not consider John 20:22 to be a fulfilment of John $14: 17 ;^{23}$ instead the promise of Jesus was realised on the Day of Pentecost i.e. the disciples had the Spirit with them up until Pentecost at which time they received the Spirit in them. Advocates of this theology saw a parallel between the disciples' pre-pentecostal state and Christians in their own time living without the pentecostal experience, but nevertheless eligible to receive the Spirit in them. For this corollary to hold, it must be true that Jesus' promise in John 14:17 was for all Christians and not limited to his immediate audience. Further, being baptised in the Spirit must be equivalent terminology for an individual having the Spirit in him.

The "with" / "in" schema has never adequately coped with Paul's statement that believers have the Spirit dwelling in them (Rom 8:9), the text obviously not implying that only the Spirit-baptised are authentic Christians. There is no evidence that the Apostolic Church made an official or definite move away from the "with" / "in" doctrine, rather it simply lost prominence. ${ }^{24}$

\section{Differentiation of the Spirit of Christ from the Holy Spirit}

The solution posed by Eynon, Scadden and McCabe to the problem of non-pentecostal Christians having the Spirit differentiates between the Spirit of Christ and the Holy Spirit and therefore may be seen to posit a fourth person in

\footnotetext{
${ }^{21}$ Rennie, Gifts, 20.

${ }^{22}$ Rennie, Gifts, 21.

${ }^{23}$ John 20:22, which records Jesus breathing on his followers and saying "Receive the Holy Spirit," is best taken to be an enacted prophecy; a symbolic gesture anticipating Pentecost.

${ }_{24}$ Wessels, writing in 1966, observed that for the Assemblies of God in the United States the "formulation, 'He is with you and shall be in you,' may be becoming unacceptable." Roland Heinrich Wessels, "The Doctrine of the Baptism in the Holy Spirit Among the Assemblies of God," unpublished Th.D. thesis (Berkeley: Pacific School of Religion, 1966), 223.
} 
the Godhead; ${ }^{25}$ opponents to this differentiation argued that if the Holy Spirit is not the Spirit of Christ then there are two Spirits of God operating in the world. Interestingly, this was the line of reasoning adopted by the Assemblies of God, ${ }^{26}$ a definite case of the Apostolic hierarchy not being influenced by their closest theological brothers.

The theological musing of this Apostolic trio draws attention to an important point in the study of the Trinity. The problem centres on determining the post-ascension nature of the Son: to what extent is the second person of the Trinity properly referred to as the Spirit of Christ? The risen Jesus, whom the disciples met following the Resurrection and who now is located in heaven, must be ontologically different from the person of Christ received in conversion by individuals since that time. That is, Christ was bodily assumed into heaven but Christians receive his spirit at conversion. A differentiation of the Spirit of Christ from the Holy Spirit allows for the belief that at conversion it is the former who is received while at Spirit-baptism it is the latter.

However, Acts 16:6-7 identifies the Holy Spirit with the Spirit of Jesus: assuming the Spirit of Jesus is the Spirit of Christ, the Holy Spirit and the Spirit of Christ are one and the same. It therefore seems unworkable to distinguish one from the other in an effort to explain the difference between conversion and Spirit-baptism.

Further, we find that Paul, in Romans 8:9, is happy to identify the Spirit of God as the Spirit of Christ. In the verse following he simply uses the appellation "Christ," presumably instead of the fuller term "Spirit of Christ." This means that the believer is indwelt by the Spirit of Christ, synonymous with the

\footnotetext{
${ }^{25}$ That is, the Godhead would consist of the Father, the Son, the Holy Spirit and the Spirit of Christ.
} 
Spirit of God who "raised Jesus from the dead" (Rom 8:11). As Gordon Fee points out in his analysis of these verses, ${ }^{27}$ Paul is outlining two possibilities: either one lives "according to the flesh" or "according to the Spirit" (v. 5). Verse ten expounds this latter case. We must agree with Fee that Paul uses the shorthand "if Christ is in you" in place of "if Christ dwells in you by his Spirit." Fee, in a specific discussion of the Spirit later in his book states that Paul chose "Spirit of God" or "Spirit of Christ" to emphasise a particular activity of either God, or Christ, toward the believer through the Spirit. ${ }^{28}$ This makes sense and must be accepted as a viable explanation of Paul's use of the two terms.

Perhaps the early Apostolics reasoned that: (i) the risen Christ was spirit so could accurately be called the "Spirit of Christ;" (ii) the risen Christ is distinguished from the "Spirit," an assumption in accordance with modern scholarship; $^{29}$ (iii) the "Spirit of Christ" is therefore differentiated from the "Spirit." The error in the syllogism, if in fact this represents the train of thought, is at step (i) viz. assuming that because the risen Christ is no longer on Earth but is located in heaven as a spirit, he can thus be called the "Spirit of Christ." This is incorrect because the Spirit is not to be identified with the risen Christ as Romans 9:1 \& 15:30 clearly show. It appears that these early Apostolic Church thinkers highlighted the ontological difference between the risen Christ and the person of Christ received at conversion; they simply got the labels wrong.

Spirit-baptism was, quite rightly, viewed as "gifts for service" and not a sanctifying work; however, it seems that the formulations of these Apostolic men, constructed as they were to explain the lack of Christ-like behaviour in

\footnotetext{
${ }^{26}$ Ernest Williams, sometime superintendent of the Assemblies of God in the United States, opposed the differentiation of the Holy Spirit with the Spirit of Christ in his Systematic Theology vol. 3 (Springfield, MO: Gospel Publishing House, 1939), 13.

${ }^{27}$ Gordon Fee, God's Empowering Presence: The Holy Spirit in the Letters of Paul (Peabody, MA: Hendrickson, 1994), 545.

${ }^{28}$ Fee, Presence, 836.
} 
Spirit-baptised Christians, overlooked the correlation between exercise of spiritual gifts and the effect of allowing the Spirit to consistently overwhelm an individual. This perhaps follows from one's "baptism" often being spoken of without reference to the need for, or exercise of, any ongoing seeking of the Spirit. While the early Apostolics did speak of continual fillings it is apparent that considerable importance was attributed to the event of their "baptism," sometimes with an element of nostalgia. However, this is best explained by the fact that frequently baptism was as the result of a long period of tarrying and so, quite reasonably, regarded as a milestone in their Christian experience.

\section{A Related Problem}

Within the Assemblies of God the "two Spirits" theory was perpetuated in the doctrine that the baptism referred to in I Corinthians $12: 13$ is different to what is described in Acts $2 .^{30}$ That is, the words of Paul relate to conversion, whereas Luke's apply to a subsequent experience. In this understanding the Holy Spirit is the agent in conversion, baptising the individual in the body of Christ, and then Christ is the agent baptising the believer in the Holy Spirit. In this second immersion Christ must be acting spiritually rather than physically. For this distinction to stand the Spirit of Christ cannot be identical with the Holy Spirit.

Originally the Apostolic Church understood I Corinthians 12:13 to refer to Spirit-baptism. President D. P. Williams stated in 1935 that it is "in the baptism of the Holy Spirit that one is equipped and qualified for the Body. ${ }^{31}$ Fellow UK

\footnotetext{
${ }^{29}$ Fee, Presence, 834 , criticises those commentators who press too strongly for an identification of Christ with the Spirit.

${ }^{30}$ Leslie Thomas Holdcroft, The Holy Spirit (Springfield, MO: Gospel Publishing House, 1979)

${ }^{31}$ This statement appeared in Williams' exposition of an interpretation of tongues given at the Apostolic Church International Convention, Penygroes, 3-11 August 1935. The interpretation of tongues made reference to the elect being gathered and Williams commented that some are in
} 
Apostolic pastor, T. C. Matthews, wrote in 1939 that "all the functions of the One Spiritual Body were due to the One baptism of the Holy Ghost received by all." ${ }^{\text {32 }}$ A prophecy at the 1939 Apostolic Church International Convention pronounced that of all people, Spirit-baptised believers should be enjoying unity due to the fact that God has filled "them with the same Spirit, and filled one body as I have filled another Body." 33 This oblique reference to I Corinthians $12: 13$ shows, from the context in which it was used, that the baptism by one Spirit into one body was equated with Spirit-baptism.

An article on the evidence of "the baptism" which appeared in a 1952 issue of the New Zealand magazine The World and New Zealand, identified some texts (viz. Eph 1:13; I Cor 6:19; I Cor 12:13) that were illegitimate for unSpirit-baptised believers to apply to themselves. The writer of the article, Joshua McCabe, put forward the argument that Paul's letters to the Corinthian and Ephesian churches were addressed to believers who had experienced the baptism of the Spirit. Therefore, Paul's statement that "all" were baptised by one Spirit describes those who were Spirit-filled believers. ${ }^{34}$

Later statements by Apostolic ministers reflected the belief that Spiritbaptism was the referent in I Corinthians $12: 13 .^{35}$ The corollary to such a view

the Kingdom, i.e. those who are saved, and others are in the church, i.e. those who are elect: Christ is gathering out of the saved ones the elect who will be brought to the Throne. Williams led into this explanation with: "The hope of the world is the Kingdom, the hope of the Kingdom is the Church, the hope of the Church is the Christ of God." Those Williams was addressing were not, he said, looking for the Kingdom because they had the King in their hearts, rather they were the elect and as such they were called to gather the elect of every nation. Williams obviously realised the exclusive nature of his doctrine because he prefaced it by saying: "I am going to say something. I don't know whether you will swallow this or not." Riches 11, no. 1 (1935): 83.

32 T. C. Matthews, "Concerning the Gift of the Holy Spirit" Riches 14, no. 6:441.

33 Prophecy through T. N. Turnbull Tuesday 8 August 1939 recorded in Floods Upon the Dry Ground: Being a Report of the Apostolic Church International Convention held at Penygroes, Carmarthenshire, S. Wales August $5^{\text {th }}$ over the 13 1939 (Bradford, Yorks: Apostolic Publications, n.d.), 109.

34 Joshua McCabe, "The Evidence Of The Baptism" World 7, no. 4 (1952): 9.

35 For example, a quote from W. A. C. Rowe, carried in Riches 15 (October 1962): 311, contained the following thought: "The Apostle Paul was a stranger to the idea that the whole Church was potentially and comprehensively baptised with the Holy Spirit on the day of 
finds Spirit-baptism to be the prerequisite for membership of the Body of Christ: by the early 1960s this was the position held by the Apostolic Church. In 1961, Riches of Grace published a series of articles by T. N. Turnbull on "The Deity and Personality of the Holy Spirit." In the issue that treated the relation of the Holy Spirit to the Body of Christ, the exclusive nature of the doctrine was clearly evident. In answering the question of when the Body of Christ was inaugurated Turnbull appealed to I Corinthians $12: 13$ maintaining that incorporation into the Body is by a "divine act" of the Holy Spirit, an experience he then defined as "power to witness, power to manifest the gifts of the Holy Spirit", terms which characterise Spirit-baptism. Turnbull is on safe ground when he asserts that it was the divine intention for all to be Spirit-baptised but he moves into doubtful territory when he insists that "since the day of Pentecost it is those who have been baptised with the Holy Spirit that have been baptised into the Body."

Turnbull built his case on the assumption that the Body of Christ was inaugurated by the descent of the Spirit on the disciples at Pentecost; on this basis he was able to conclude that, because those who received the Spirit were already disciples and therefore regenerated, the filling of the Spirit "is what baptised them into the Body of Christ, and it baptises everyone else into it." He followed this with the definitive statement that the church is comprised of Christians of all denominations who are "baptised with the Holy Spirit." ${ }^{36}$ Turnbull did not, however, reject unSpirit-baptised Christians; rather he said

Pentecost. The Holy Spirit, through the Apostle, declares 'By one Spirit ARE we all baptised into one body"' (I Corinthians 12:13).

The sermon of R. L. Davies given at the Apostolic Church International Convention, Penygroes, 1962, printed in Riches 15 (December 1962): 365, included the lines: "The Lord is doing a quick work in winding up this dispensation therefore let us see to it that every member without exception - has a personal experience of the baptism in the Holy Spirit. Body identity is unfolded by Paul in I Corinthians 12:13, "we are all baptised into one body by one Spirit."

${ }_{36}$ Turnbull, "The Deity and Personality of The Holy Spirit: The Holy Spirit and The Body of Christ," Riches 14 (July 1961): 219. 
they resemble "Old Testament Christians" who are in the "spiritual kingdom."37 There was no immediate reaction against the doctrine within the Apostolic Church; in fact it continued to be taught, similar teaching from Turnbull being published in $1963 .^{38}$

\section{Tarrying}

Luke differs from the other gospel writers and Paul in that he describes a work of the Spirit subsequent to conversion. A pertinent question relates to the necessity of a time delay between conversion and Spirit-baptism as opposed to positing a logical distinction between the two. The first generation Apostolics in Great Britain were primarily evangelicals who had come into an experience of the Holy Spirit. Preaching on the topic of baptism in the Holy Spirit was therefore directed mostly towards the converted, and centred on encouraging them to seek the gift. From this position of motivating and instructing the faithful to become Spirit-baptised, the mentality grew that there was a necessary period of waiting for the gift.

The point has been made by Pentecostals and charismatics alike that the disciples' wait in Jerusalem for the descent of the Spirit was a unique necessity. If the focus is on elapsed time then the logical conclusion of such an observation is that tarrying in the present day is entirely irrelevant. However, Apostolic proponents of tarrying have never advocated that time is an essential ingredient, rather, what transpires in the process. It is here that the tarrying doctrine attracts the charge of promoting the fulfilling of "conditions." That is, if

\footnotetext{
37 Turnbull, Riches, 220. "Old Testament Christians" is more accurately rendered "Old Testament believers."

${ }^{38}$ Riches published a series of articles in 1963, written by Turnbull, entitled "The Gifts in Corinthians." In his discussion of "Christ's Mystical Body" Turnbull declared that "it is by the baptism of the Holy Spirit we are made members of The Body of Christ." Riches 16 (May 1963): 145.
} 
there is a preparatory work necessary to receiving the Spirit, then the "faith alone" maxim is contravened. Rodman Williams explains that "conditions" associated with receiving the Spirit are expressions of faith rather than additional requirements to faith. It is active faith which is all important, expressed in prayer, obedience and yielding. ${ }^{39}$ Rowe, in a useful discussion on conditions, showed that the gifts of God are conditional: salvation, while free, depends on faith, repentance, and confession. ${ }^{40}$ The "conditions" were not so much hoops to jump through, but instead responses of the heart. It just so happened that there emerged a commonality in the types of values and actions that preceded a seeker coming through in the baptism that they were collated and presented in sermons and articles.

Of the various conditions advanced, cleansing oneself of sin could be seen to be a works righteousness effort. In Bruner's treatment of conditions he assesses pentecostal teaching to be that a heart without sin is a prerequisite to Spirit-baptism. In the course of doing so, however, he incorrectly interprets both Myer Pearlman and A. J. Gordon as saying that Spirit-baptism results from sanctification having progressed to the required point, when they are simply referring to the acceptance by God that an individual enjoys on becoming a Christian. ${ }^{41}$ The action of cleansing is best understood in the context of a person's response to God. When it is remembered that letting God search the heart to highlight $\sin$ (Ps 139:23-24) is a normal Christian activity, cleansing fails to qualify as the human addition of merit to grace, as indeed do any of the

\footnotetext{
39 J. Rodman Williams, "Baptism in the Holy Spirit" in Dictionary of Pentecostal and Charismatic Movements, ed. Stanley M. Burgess and Gary B. McGee (Grand Rapids, MI: Zondervan, 1988), 48.

${ }^{40}$ William A. C. Rowe, The Pattern of Pentecost (n.p., n.d.), 25-26.

${ }^{41}$ Bruner, Theology, 93-98. The quote from Myer Pearlman, Knowing the Doctrines of the Bible (Springfield, MO: Gospel Publishing House, 1937), 318: "As sinners we accept Christ, as saints we accept the Holy Spirit." The quote from A. J. Gordon, The Ministry of the Spirit (Grand Rapids, MI: Zondervan, 1949), 68-69: "It is as sinners that we accept Christ for our justification, but it is as sons that we accept the Spirit for our sanctification."
} 
conditions. Expanding the concept then, being overwhelmed by the Spirit, as "baptism" connotes, results from surrender of the individual's life to the Lord; to the extent that this occurs at the moment of salvation determines whether Spirit-baptism is coincident. This explains the variability of experience with respect to its chronology: some baptisms are coincident with salvation, although logically distinct, while others are subsequent.

Environment or spiritual climate must have an effect here. Where God's presence is strongly evident, producing deep repentance and radical lifestyle change, there also is the opportunity for those coming to Christ to be Spiritbaptised in the same trip to the altar. Expectation, a product of the theological milieu, provides a similar effect. If the teaching and practice of a church promotes an "it can all happen now" approach then it most likely will for any given individual. Similarly, it is probable that a period of seeking will occur in an environment where tarrying is the norm. ${ }^{42}$ It is noteworthy that Apostolic leaders did not consider tarrying an absolute requirement to receiving the Spirit, but it featured in a majority of cases. Over against opponents of tarrying, Apostolic pastors did not encourage, or necessarily expect, a protracted period of tarrying for any given individual.

Prophetic guidance on tarrying came to the Apostolic Church Commonwealth Council of 1934 through W. Jones Williams and Joshua McCabe. The first message emphasised that the purpose of tarrying is to seek the Holy Spirit, not "anything that the Holy Spirit hath for the individual." ${ }^{43}$ This forms an adequate basis to the view that conditions are not so much prerequisites to be met in order to receive a free gift, as they are appropriate

\footnotetext{
${ }^{42}$ The reasons for this are outside the bounds of the present focus but would necessarily include discussion of psychological influence and the varied operations of the Spirit.

${ }^{43}$ Apostolic Church Commonwealth Council Minutes of The Great Centenary Convention, Melbourne, October-November 1934, pp. 81-83.
} 
demeanours for any yielded Christian keen to know more of God. The message via the prophet McCabe focussed more on practical detail, conveying the instruction to schedule tarry meetings as often as possible and to "let it be upon the Saturday afternoon." The prophecy dictated that only men were to lay hands on seekers in tarry meetings, the prophet identifying laxity by some pastors in allowing women to perform this task. ${ }^{44}$

Once the doctrine was accepted by individuals, there began the process of seeking. The giver, not the gift, was the goal of seeking, so an individual was inevitably brought closer to God, a situation which always highlights personal failings and prompts repentance. The frequent times of prayer and waiting on God in the company of others provided an environment conducive for the seeker to succeed in his quest.

The Apostolic Church was not alone in promoting the doctrine of tarrying, the Assemblies of God at the time teaching likewise. Ralph Riggs, sometime general superintendent of the United States Assemblies of God General Council, in describing how to receive the baptism in the Holy Spirit, endorsed the universal applicability of the Lk 24:49 command: the disciples would have given the same admonition to their converts. In explanation for many not receiving Spirit-baptism, Riggs found a parallel in that if the 500 mentioned in I Cor 15:6 heard the command, then apparently only 120 obeyed and therefore received. ${ }^{45} \mathrm{He}$ continued by stating the necessity of asking with importunity, adding belief as a prerequisite and, while acknowledging the uniqueness of the original situation, confirmed that "waiting or tarrying before the Lord is always Scriptural and is normal procedure in receiving from God." ${ }^{46}$

\footnotetext{
${ }^{44}$ Council minutes, October-November 1934, pp. 86-87.

${ }^{45}$ Riggs, Spirit, 103.

${ }^{46}$ Riggs, Spirit, 107.
} 
The "conditions and procedures" mentioned by Thomas Holdcroft some years later are not inconsistent with the thoughts of Riggs. Holdcroft produces a list, one or more of which he suggests is required in order to receive the Gift, and includes faith, obedience, personal purity, wholehearted desire and the Spirit of praise. ${ }^{47}$ Although Holdcroft has not used the words "tarry" or "wait," there is the stated need for persistence in the exercise and for praying until a particular character of prayer is achieved, both activities which require the element of time.

Receiving the baptism was an unmistakable event; a seeker who "breaks through" could be in a heightened state for hours displaying various degrees of oblivion to the surroundings. ${ }^{48}$ By contrast, in the modern setting the depth of experience appears to have diminished, giving way instead to a less cataclysmic encounter, a swift and easy process, a hallmark, it may be argued, of the charismatic movement. By way of illustration, the depth of experience expected in the highly successful charismatically inclined Alpha course is evidenced by the manner in which being filled with the Spirit is accommodated. A weekend away in the latter part of the 10 week course included a Saturday evening prayer session where attendees would receive the Spirit, followed thirty minutes later by participation in a variety concert. Evidently, Alpha course organisers had little anticipation of participants being "drunk in the Spirit": there seemed to be little thought of those receiving the Spirit being so affected by

\footnotetext{
47 Leslie Thomas Holdcroft, The Holy Spirit: A Pentecostal Interpretation (Springfield, MO: Gospel Publishing House, 1962), 116-119.

${ }^{48}$ A representative account is given here by retired Apostolic Church minister Allen Arnold. He describes his 1937 baptism in the Spirit, which took place during a youth meeting in a private home: "We were a small group, at the most six or eight. Following the opening exercises we moved into prayer, seeking God, no doubt on my behalf. Before long the anointing of the Spirit was upon me and my prayer and praise began to change from stammering lips to a "baby tongue", and soon to an articulate utterance which continued for about an hour. For days and weeks afterwards I seemed to be immersed in the Spirit, and full of the heavenly language. It has never stopped." A. V. Arnold, letter to W. L. Worsfold, 25 June 1997.
} 
God's presence that they would neither want nor be capable of participation in entertainment of a secular nature. ${ }^{49}$

Some Apostolic pastors consider that the lightness of experience seen currently correlates with the practise of receiving the Spirit with a minimum of preparation. Tarry meetings have long since been missing from pentecostal church schedules. This, coupled with the immediacy of the Spirit's power upon individuals via Toronto blessing type environments, has only served to strengthen the perceived redundancy of preparation. That such thinking is apparent in the charismatic setting is perhaps best exemplified by the Alpha Conference in Auckland, 1996. During the evening session on the second day, convenor Sandy Millar stated that when prayer is offered for the Holy Spirit to be received the individual receives potentially everything from the Spirit. After initiating a time of worship, Millar led the assembled body in a prayer inviting the Holy Spirit to come. After waiting for a few moments he told the delegates that, on account of having asked, they had received the Spirit. He assured the assembled crowd that it was "not wishful thinking, but we have received." Presumably as evidence that Spirit reception had occurred, he then inquired of the conference delegates, "Who feels an anointing for evangelism? Intercession?" and other spiritual gifts. Millar mentioned various giftings, indicating that these were now present in some people, although he did not specify who. ${ }^{50}$

\footnotetext{
${ }^{49}$ When Alpha was introduced to New Zealand it came with an overt charismatic theology. At the Alpha Conference held at Holy Trinity Cathedral, Auckland, October $24-25$ 1996, presenter Nicky Gumbel said quite emphatically that the gift of the Spirit "is not a second blessing."

${ }^{50}$ Millar, in addressing the general concept of spiritual gifts earlier, said, "We are through seeing the gifts as distinguishing two classes of people." He also displayed something of the Alpha hierarchy's development in thinking saying, "We used to think people had to be further down the line before we prayed with them to receive ... not sure how they were supposed to get there ... now it's as soon as they understand." Elaborating the theology, he admitted to previously thinking that the "Spirit was sent to fill the absence of Jesus" but that current belief was the "Spirit is to ensure the presence of Jesus."
} 
Tarrying was not without its detractors however and opposition to the doctrine found its expression in the alternate model of the Latter Rain movement. It is important to note the effect of such a movement on the Apostolic Church, so to this we now turn.

\section{Latter Rain}

During the evangelical awakening following World War II there arose a move of the Spirit similar in some respects to the revival which began at Azusa St in $1906 .^{51}$ Centred originally in Canada, the sparks of this revival were carried across North America and around the world. ${ }^{52}$ Based on an interpretation of Joel 2:23, which refers to former and latter rain, many people identified the revival with the outpouring of the Spirit expected to precede the Second Coming, labelling it the "Latter Rain Movement."53 Miraculous healings, laying on of hands to receive the Spirit, and a decentralised form of church government were all features of the Latter Rain Movement which distinguished it from the earlier Pentecostal revival. The last two mentioned, laying on of

${ }^{51}$ Richard M. Riss, Latter Rain: the Latter Rain movement of 1948 and the Mid-Twentieth Century Evangelical Awakening (Ontario: Honeycomb Visual Productions Ltd, 1987), 76-77, catalogues the following similarities: belief in an imminent return of Christ; emphasis on spiritual gifts; the prerequisite of Spirit-baptism for receiving spiritual gifts; exercise of laying on of hands to receive both spiritual gifts and the Spirit; attention given to prayer and fasting; importance of "spiritual" worship.

${ }^{52}$ The Latter Rain revival was experienced mainly by autonomous churches hence its influence tended to be restricted. Edith L. Blumhofer, Restoring the Faith: The Assemblies of God, Pentecostalism, and American Culture (Urbana and Chicago: University of Illinois Press, 1993) addresses in chapter nine of this work, the interplay between pentecostal denominations in the US and the New Order of the Latter Rain. She points out that the latter rain movement "directed its criticisms of the status quo almost exclusively at other Pentecostals." New Order advocates saw in the denominational structure the declension of pentecostal power; denominations were considered to be obstacles to God's work. The biblical model, according to latter rain thought, was for each local church to develop five-fold ministry after the manner of Eph. 4:11 and operate as a self-contained unit while maintaining a cooperative attitude with other autonomous congregations. The stance taken by latter rain in this regard explains why denominations resisted its influence. However the Latter Rain revival did leave a legacy in that elements of the revival were catalytic for the later charismatic renewal.

${ }^{53}$ Further support for labelling the last days Spirit-outpouring as the latter rain is found in James $5: 7,8$ "Therefore be patient, brethren, until the coming of the Lord. See how the farmer waits for the precious fruit of the earth, waiting patiently for it until it receives the early and latter rain. You also be patient. Establish your hearts, for the coming of the Lord is at hand" (NKJV). Cf. Hos 
hands and local church autonomy, became points of contention between proponents of the Latter Rain and the established pentecostal churches.

Latter Rain proponent and former Methodist minister J. E. Stiles emphasised the gift nature of the "gift of the Spirit" and concluded that tarrying to receive was unnecessary. Rather, the gift was gained by a fellow believer laying on hands. The doctrine of tarrying was a foundational pentecostal belief. William Rowe's book, The Pattern Of Pentecost, was written in reaction to Stiles' publication, The Gift of the Holy Spirit, in particular the "Stiles' method" of receiving the baptism without actually mentioning it. ${ }^{54}$

The Apostolic Church was founded on the revelation of the restoration of the apostle and prophet ministry, innovations most evident in its practice of "divine government". This was a highly centralised form of control and in stark contrast to the independence espoused by Latter Rain protagonists. Needless to say, the influence of Latter Rain on the principles and practices of the Apostolic Church was viewed with caution by the church administration while at the same time rejoicing in the obvious move of the Spirit. The New Zealand Apostolic Church, ostensibly displaying confidence in the new movement, published in a 1951 issue of The World and New Zealand an article which included the statement that "the LATTER RAIN REVIVAL is nothing more than a great awakening and restoration of the ministries and gifts with miracles and signs, seen forty years ago." 55 The article itself, entitled "The New Revival In

6:3 "Let us know, let us pursue the knowledge of the Lord. His going forth is established as the morning; He will come to us like the rain, like the latter and former rain to the earth" (NKJV).

${ }_{54}$ James Worsfold, NZ Apostolic Church minister 1950-96, in conversation with W. L. Worsfold.

${ }^{55}$ Glenn W. Ewing, "Our Lord's Ministry," World 5, no. 2 (1951): 19. Ewing was, at the time, pastor of Grace Gospel Church, Waco, Texas which had been experiencing the revival for several years. Ewing's church produced a newspaper from which a compilation of extracts was published by World the previous year. The World editor's preface declared that the information from Ewing "leaves no doubt that the substance of the American Revival of today is exactly the same as came to Great Britain in the early part of the present century and upheld today in Apostolic Churches world-wide. There may be differences in interpretation, but the great substance of the faith is the same." World 4, no. 1 (1950): 10-11. 
America on the Apostolic Pattern," extolled the virtues of church government following the New Testament pattern utilising the ascension gifts (Eph 4:11) and spiritual gifts (I Cor 12:8-10). The support shown by the Apostolic Church for the Latter Rain belied the concern that the leaders had over its influence both doctrinally and in terms of allegiance. James Worsfold records in his History that the Reverends A. L. Edmonson and R. Jackson were associated with Bethel Temple in Seattle, with Jackson later returning to New Zealand. ${ }^{56}$ Richard Riss documents the success of Jackson's meetings despite the antagonistic reception of him in New Zealand. Jackson began ministry in Auckland in 1950 but left the following year to establish a like ministry in Australia. Initially he was advised by the Australian Apostolic Church that his invitation was withdrawn; however, they subsequently encouraged him to join them. He recalls:

After a year or so I was led to go to Australia. Again I was met at the Airport by an elder of a certain Pentecostal denomination [the Apostolic Church]. I was told they had sent a cable for me not to come. I was not wanted. I said, "I received no cable, and even if I had, I would have come because I was not coming by an invitation of man."

So, they took me to the chairman of this denomination [W. A. C. Rowe] and inasmuch as I was in the country, they thought it best to get me to join them. They tried to presuade [sic] me to take out papers, saying there was no other group that was progressing, but I told him I had not come to join. I had been asked to join in a lot of countries. I said, "God's doing a new thing, wanting His people to come together." But it was an ultimatum - join or else - and so, since I didn't agree to join, he called a district meeting of the preachers, warning them against me. ${ }^{57}$

Considerable disquiet existed amongst the New Zealand Apostolic Church leaders regarding the extent to which their overseas brethren had embraced

\footnotetext{
Worsfold, History, 297-298, provides an outline of Latter Rain teaching in almost positive tones stating that "what the teaching amounted to was a re-emphasis on the Baptism of the Holy Spirit, the Gifts of the Holy Ghost, particularly the gift of prophecy and the word of knowledge, singing with the spirit, with scripture set to music, the ministry of the laying on of hands and that of apostles and prophets. As an outcome of this forthright preaching, faith was generated in the many revival services conducted in New Zealand to see the Holy Spirit being manifested in a greater way."

${ }_{56}$ Worsfold, History, 297.

${ }^{57}$ Ray Jackson, Sr., letter to Richard Riss, 16 March 1977, quoted by Riss, Latter Rain, 135-6.
} 
Latter Rain and consequently thrown over the Apostolic vision of a centralised divine government. The covering letter accompanying the minutes of the annual council meeting of 1951 posted out to all pastors advised that extracts of recent letters on the topic of the Latter Rain from "Canadian and USA brethren" would be "sent out separately for handy reference, and may be shown discreetly to those who have been misled by such rumours." 58 It appears from the content of the letters that the general secretary of the Apostolic Church in Britain had written to the North American Apostolic Church, expressing concern regarding their involvement with and allegiance to the "Latter Rain Movement" ${ }^{59}$ Their responses were obviously forwarded to the New Zealand council for their information and use. Cecil Cousen, completely amazed at the remarks made, came to the conclusion "that you must have received some misrepresentation of the true state of affairs out here. We have not joined the Latter Rain movement. There is no movement to join, in the very essence of the nature of the visitation of God. It is fundamentally a coming together of the Body of Christ." Cousen, a Briton who had emigrated to pastor the Apostolic Church in Hamilton, Ontario, affirmed his adherence to the Apostolic Vision and denied that the North American church was seceding from its mother in Great Britain. T. K. Mitchell reported that "miracles are being wrought, devils are being cast out, folk are being baptised immediately by the laying on of the Apostles' hands, without the usual protracted scenes of tarrying, etc."

\footnotetext{
${ }^{58}$ Minutes of the Dominion Council, Wellington, Easter 1951, cover letter by Alex Gardiner.

59 In the USA the Assemblies of God had been displaying similar misgivings concerning Latter Rain. At their 1949 general council, the Assemblies of God disapproved of three practices: identification and impartation of spiritual gifts through prophecy and laying on of hands; the existence of present day apostles and prophets equivalent to those on which the church was founded; confession of sin by a penitent and subsequent granting of absolution by the confessor. Blumhofer, Restoring the Faith, 211. On the first of these points the Apostolic Church would have been similarly opposed, but for a different reason: spiritual gifts were considered verifiable or even bestowable through prophecy and laying on of hands, however, such action was the prerogative of officers appointed and recognised nationally within the denomination not those
} 
Defending the emergence of apostolic ministry he remembered "how often has the Lord said to us as a Council that He will give Apostles to other people. If we fail then will He raise up others with the same vision." He destroyed the notion of there being a Latter Rain Movement as such and pointed out that they themselves had "not joined some other movement. I fail to understand how you have gathered that impression." B. G. Evans confirmed that "as far as Canada is concerned you have nothing to be alarmed about. We are $100 \%$ Apostolic". Evans also denied that Latter Rain was a movement; rather he said, "it is an experience with God". 60

Similar sentiment was expressed from the United States; F. C. Poole wrote that "there is no such thing as a Latter Rain Movement," it is instead "the outpouring of His Spirit for these Last Days." He reassures his reader that if there were he would not join, but rather he is "more Apostolic today than I ever was". He emphasised the visitation as "end-time," believing the Apostolic Church to have a great part in it. ${ }^{61}$ B. J. Noot reported cautiously, stating that the laying on of hands was used for "gifts and liberations. In this I consider they carry it too far." The perceived lack of accountability of the itinerating apostles

\footnotetext{
who operated only locally. The second and third points would have elicited like response from the Apostolic Church and the Assemblies of God.

${ }^{60}$ It seems the fear of the British Apostolic Church that the daughter church in North America was undergoing a wholesale transfer of allegiance to Latter Rain was fuelled by the removal of the appellation "Apostolic" from church buildings in Canada. The Toronto pastor, F. Warburton, explained the dropping of the title as due to unfortunate associations the name carried in Canada, reassuring his total devotion to the "Apostolic principles and message." W. T. Davies represented the Canadian stance more generally, arguing that many groups included the word "Apostolic" in their title including "some of them with not too good a name." Minutes, Wellington, Easter 1951, pp. 34-35, carries extracts of letters from Cousen, Mitchell, Evans, Warburton and Davies.

${ }^{61}$ Minutes, Wellington, Easter 1951, p. 36. This page also carries an extract from a minute passed at a special meeting of the United States Apostolic Church executive, pastors and deacons in January 1951. The meeting released Pastor Poole "to minister, as an apostle, to other companies of the Lord's people." Convinced of the "last-days" nature of the move, the minute recorded that "thousands" had embraced the doctrine of the church receiving ministry gifts, viz. apostles, prophets, evangelists, pastors and teachers, with these being "called and set in the Body."
} 
to any "Council or higher authority" concerned Noot, who related that he did not feel led of the Lord to follow the practitioners of the Latter Rain. ${ }^{62}$

In April 1951 Poole, Evans and Cousen attended the Apostolic Church Council Meeting in Bradford, the resultant ministry from these men bringing something of the Latter Rain to the church. However, despite this positive effect on the rank and file of Apostolic ministers, in 1952 all pastors of that denomination were required to reaffirm their adherence to the constitution. Cousen felt unable to do so and was asked to resign. ${ }^{63}$ It appears that the leadership of the Apostolic Church maintained their wary appraisal of the Latter Rain and, according to Cousen, the executive council convinced Poole and Evans "not to decentralize so quickly." ${ }^{64}$ The Latter Rain's position on autonomous authority posed an immense threat to the central control mechanism of the Apostolic Church. Cousen recalls that "a lot of the pastors [of the Apostolic Church] were open, and were prayed for, and were changed. But behind the scenes the powers that be, especially the Executive, which was led by a very strong man by the name of pastor Hugh Dawson, . . . believed in the Apostolic Church as such, and especially in divine government." ${ }^{\prime 65}$

The practice of laying on of hands for the gift of the Spirit was at theological variance with the accepted method of tarrying for the baptism. The freedom of the newly-called apostles was something of an irritant to a church hierarchy which had thrived on promoting men to successive levels of control, each accompanied by a greater degree of secrecy and hence group solidarity and power. ${ }^{66}$ The Apostolic Church in New Zealand was only recognised as

\footnotetext{
62 Minutes, Wellington, Easter 1951, p. 37.

${ }^{63}$ Riss, Latter Rain, 139.

${ }^{64}$ Riss, Latter Rain, 138.

${ }^{65}$ Riss, Latter Rain, 137.

66 In New Zealand Pastor Pickles objected that "callings . . . are only allowed in the Council meetings and not even the men concerned are allowed to hear. You have made these secret
} 
autonomous by Great Britain in 1942, so for a considerable period any influence on the Apostolic Church in the "home country" definitely affected the local scene. The Latter Rain emphasised autonomy, thus eschewing the centralism that was outworked by the Apostolic Church through apostles and prophets and creating an attitude of defensiveness amongst the leaders of this church. Remembering that baptism in the Spirit was seen as the gateway or precursor to the impartation of spiritual gifts, the relative ease with which Latter Rain proponents effected the baptism signalled to Apostolic Church administrators their failure to recognise the tremendum in the process of receiving the Spirit, with a consequent devaluing of gifts, especially prophecy.

The doctrine of tarrying was required to answer questions regarding what delayed the reception of the Spirit in any given individual, an area of enquiry which became a target for the anti-tarrying teaching promulgated by proponents of the Latter Rain. A core activity of the Apostolic Church, viz. the tarry meeting, perhaps succumbed to the teaching that reception of the Spirit is immediate upon request.

\section{The Charismatic Movement}

The 1959 Spirit-baptism of Dennis Bennett, the Episcopal clergyman in Van Nuys, California, is generally taken to be the genesis of the Charismatic Movement. This does not mean that there was no evidence of Spirit-baptism in the historic churches before this point, but Bennett's encounter with the Spirit and the church hierarchy was the catalyst for establishing a pervasive

meetings a principle and the decisions that come from them must be accepted without question." W. W. Pickles, letter dated 17 April 1950, to Alex Gardiner, Dominion secretary Apostolic Church Council NZ, reproduced in the minutes of the Biennial Dominion Council Meeting, Wellington, 11-13 April 1950, p. 15. Pastor Pickles wanted to be consulted over any decision that involved his relocation and he would not accept a judgement made otherwise. Alex Gardiner, himself assured of the infallibility of the apostles' direction, was rankled by such a 
charismatic presence. ${ }^{67}$ The development of organised charismatic groupings ${ }^{68}$ within several of the historic churches meant that members who had experienced Spirit-baptism found a circle of acceptance and so they tended to remain in their denominations instead of joining pentecostal congregations. This was not always received with much enthusiasm by Pentecostals, who felt that the experience was worth standing up for and that it demanded a full expression not possible in the historic churches. Acutely aware of the ostracism and labels of "cult" applied to them in former years, Pentecostals sometimes resented the ease with which Christians in the historic churches could receive the Spirit and at the same time maintain their status as belonging to a "respectable" denomination.

The term "Neo-Pentecostal" reflected something of this attitude: used by Pentecostals and outside observers, the appellation was not welcomed by charismatics who instead preferred to be described as participants in the "charismatic renewal." Pentecostals considered charismatics to be inferior in lifestyle, enduring an abbreviated gospel in their services while dabbling with spiritual gifts in small-group meetings. Pentecostals' long struggle for acceptability produced an elitist mentality. The convenors of the 1976 World Pentecostal Conference in London refused to extend an invitation for noted scholar Walter Hollenweger, himself not a Pentecostal, to be present on the platform at one of the evening sessions that he was attending. ${ }^{69}$

stance and he conveyed this in a letter to Pickles three days earlier. Alex Gardiner, letter dated 14 April 1950, to W. W. Pickles, reproduced in the minutes, Wellington, 11-13 April 1950, p. 12. ${ }^{67}$ See M. Hutchinson, "The Canada Fire: Revivalist Links between Canada and Australia," 11, unpublished work.

68 Stanley M. Burgess and Gary B. McGee, Dictionary of Pentecostal and Charismatic Movements (Grand Rapids, MI: Zondervan, 1988), 136, shows that the Roman Catholic, Episcopalian, Lutheran, Mennonite, Methodist, Orthodox and Presbyterian churches each established a denominational agency to foster and channel charismatic activity.

${ }^{69}$ Mrs C. M. Worsfold, letter to Luke Worsfold 1998, recalls the attempt of her late husband the Rev J. E. Worsfold, at the time a World Pentecostal Council member, to have the courtesy extended to Hollenweger. 
The response of the Apostolic Church to the charismatic renewal was a complex one. In the years 1961-1970 Treasures of Grace, and later on Apostolic Life, carried several reprints of articles from Christian publications and the secular media reporting the renewal in Anglican and Roman Catholic circles particularly. However, while there was excitement and a sense of validation of the pentecostal experience, there was also a note of caution. Ivor Cullen, writing in a 1968 issue of Apostolic Life, observed that Spirit-baptism was now the experience of those who previously had "strenuously opposed it." However, he lamented the tendency in the charismatic renewal for control of spiritual gifts to rest solely with the individual exercising the gift, finding the solution to the problem in recognising the offices mentioned in Ephesians 4:11. Cullen believed that the Apostolic Church possessed a God-given opportunity to assist churches in the Renewal to formulate ways for the charismata to be "properly governed and controlled." Such governance, he explained, would be through the implementation of church appointed leaders. While the president believed that the Apostolic Church had a particular role to play in this education, he made no comment as to how this might be effected. ${ }^{70}$

On the related topic of behaviour Apostolic pastor Lewis Derry remarked that "the renewal of the Charismatic Ministries" does not necessarily endorse an individual's standard of holiness. He commented that the witness of those Spirit-baptised was frequently "rendered ineffective through obvious inconsistencies in their life and character." Although he gave no examples of what he deemed to be inappropriate behaviour, the fruit of the Spirit was heralded as the true expression of developing "Christian life and character." While Derry was writing in Treasures of Grace it is apparent that he is

\footnotetext{
${ }^{70}$ Ivor L. Cullen, "The Challenge of the Open Door" Apostolic Life 12, no. 4 (1968): 3.
} 
addressing a problem perceived to have been plaguing more than just the Apostolic Church, or the wider pentecostal movement for that matter. In fact, it may be argued that the writer's intention was simply to point out deficiencies in the management of the charismatic movement. ${ }^{71}$ This report marks a definite change in Derry's assessment of the renewal, at least in regard to some aspects. Six months earlier he had provided a glowing report in which he considered the Spirit's outpouring as "reviving, restoring and uniting the Christian Church." He felt that the spread of the movement, the status of those becoming involved and the effect on individuals all contributed to the authenticity of the Renewal as God's work. Evident in Derry's writing is the sheer relief that there was an "awakening to the glorious Truth" of Spirit-baptism as a valid contemporary experience. ${ }^{72}$

In the same year NZ Apostolic pastor Marcus Goulton met with Apostolic Church pastors Niswander and Poole in the USA to assist them in their response to the Renewal. The May-June issue of Treasures of Grace carried a report by Niswander. The title, "An Effectual Door" reflected the hope of the author for the Apostolic Church to provide direction to those affected by the Renewal, the article referring to the quest of Spirit-filled believers for a solution to the perceived "lack of balance and the lack of spiritual control," particularly with respect to prophecy. Niswander's solution was church government of the apostolic model, and made reference to people's desire to be in, and establishment of, apostolic fellowships. Niswander mentioned his involvement with the Inter-Church Teams Ministry, a body comprised of pastors from historic

\footnotetext{
${ }^{71}$ Lewis J. Derry, "The Standard of Conduct for Spirit-Filled Christians" Treasures of Grace 12, no. 1 (1968): 8.

${ }^{72}$ Lewis J. Derry, “The Promised Pentecost” Treasures 11, no. 4 (1967): 3.
} 
churches, but it is not clear from his report just how he thought the Apostolic Church herself would take advantage of this opportunity for influence. ${ }^{73}$

The slower growth rate of the Renewal in the UK, relative to New Zealand and the United States, resulted in a delayed effect on the pentecostal church there. However, by 1980 UK Apostolic pastor P. Powell was echoing similar concerns about regulating the charismata. Writing in Riches of Grace he showed his gratification that denominations originally antagonistic to Spiritbaptism had come to the point of experiencing it. His enthusiasm is evident in the over-generalisation that "the baptism of the Holy Spirit is now looked upon as becoming the normal occurrence in the life of the believer, instead of being termed abnormal." Then in an obvious endorsement of Apostolic Church structure, Powell devoted half of his article to the need for appropriate governance of the newly acquired spiritual gifts. ${ }^{74}$

In 1985 Riches of Grace published an article by NZ Apostolic pastor Rex Meehan which assessed the response of Pentecostals in general, and Apostolics in particular, to the Renewal and found it wanting. Meehan's observations were that the once necessary exercise of Pentecostals defending their belief became redundant resulting in there being something of a challenge to their continued existence as a distinct body. According to Meehan, the lack of sanctification of the new charismatics which proved so irksome to pentecostals caused the latter group to either ignore or compete with the Renewal. The Apostolic Church, he reasoned, found reassurance in their Godgiven and unique mandate of exercising divine government through the ascension gifts, believing that the counsel of the Apostolic Church would be sought by charismatics wanting to effect biblical government. This confidence

\footnotetext{
73 Dwight E. Niswander, “An Effectual Door" Treasures 11, no. 3 (1967): 11-12.

${ }^{74}$ P. Powell, "Holy Spirit Leadership and Christian Renewal" Riches 4, no. 3 (1980): 41.
} 
was ill-founded: Apostolic Church input was neither invited nor even known about. Referring to C. Peter Wagner's "third wave," Meehan described it as incorporating New Testament truth, of which the Apostolic Church had previously considered herself to be exclusive guardians. Meehan recommended that his denomination recognise the third wave as authentic and, in humility, ask God to enable them to be a part of it. The Apostolic Church, he said, could view their function in an analogous way to the relationship of John the Baptist to Jesus, viz. a harbinger which receded from prominence with the dawn of the "greater ministry." However, Meehan proffered an alternate approach for the Apostolic Church. He paralleled the possible path of the movement with that of the Apostle John: he was probably a disciple of John the Baptist who had become part of a greater revelation (see John 1:35-42). The implications for the Apostolic Church were clear: "be part of a former wave or be caught up in a fresh surge forward of the incoming tide."75 The appearance of this article is notable for two reasons: firstly that an Apostolic Church minister would produce such a courageous piece of writing forthrightly evaluating the attitude of his denomination with respect to the renewal; and secondly, that the Apostolic Church in Great Britain, far more parochial than her antipodean counterpart, should print it. ${ }^{76}$

Even so, old attitudes die hard: the Apostolic Church in Great Britain has only in recent years reversed its reticence in associating with the charismatic movement. The Apostolic Church in Great Britain was slower to embrace ecumenism than the daughter church in New Zealand. British Apostolics held

\footnotetext{
${ }^{75}$ Rex Meehan, "Catching the Next Wave" Riches 1, no. 7 (1985): 105-106.

${ }^{76}$ According to Meehan, there was no response from anyone in Apostolic Church circles either in NZ or the UK. Some outside the denomination, however, found the article helpful and used it to formulate writing of their own. The request for an article by Meehan followed a visit he had made to Apostolic Churches in the UK and Europe where, according to his recollection, he "was
} 
strongly to their divine mandate and regarded any fraternisation, even with other Pentecostals, as potentially diluting the specific revelation that was, and to some extent still is, the movement's hallmark. ${ }^{77}$ The situation was a little different in the antipodes. In 1945 the Apostolic Church, along with the Pentecostal Church and the New Covenant Church, took part in an Assemblies of God initiated attempt at unification. However, the discussions produced no tangible result: the Apostolic Church practice of ordaining men to the offices of apostle and prophet proving to be a point of theological difference that defied resolution. $^{78}$ In 1964 it was the Apostolic Church which instigated a unity conference, inviting dialogue with the Assemblies of God and the Elim Church which, although effecting no organic union, did result in a draft for the later formation of the New Zealand Pentecostal Fellowship (NZPF). ${ }^{79}$

The highly ordered nature of the NZPF, with its constitution outlining activity, doctrine and ethics eventually gave way to localised, less structured fraternities open to any minister, Pentecostal or not, who chose to identify with the charismatic renewal. While pentecostal-charismatic ecumenism fostered a spirit of unity it also influenced the extent to which Pentecostals continued to adhere to long held beliefs and practices. Pentecostals came face to face with other Spirit-filled Christians who had come by their experience without tarrying

probably flavour of the month." Meehan himself was a "little surprised" that his submission was published. Rex Meehan, email to Luke Worsfold, 16 October 1999.

77 In England during 1945 representatives from the Apostolic, Assemblies of God and Elim denominations met together to discuss unity, including the establishing of a pentecostal fraternal. The Apostolic Church, while supportive, proceeded cautiously enumerating six points of doctrinal divergence. One such point relating to the exercise of prophecy stated that while all three denominations believe in "miraculous prophetic utterance" the Assemblies of God and Elim Church are "not prepared to go so far as the Apostolic Church." Minutes of the NZ Apostolic Church Annual Dominion Council Meeting, 21 March 1945, pp. 59-61, reproduces the UK Apostolic Church "Report On The England Unity Conference."

${ }_{78}$ Worsfold, History, 311 . Earlier attempts at unity within the pentecostal fraternity were made by the now defunct Pentecostal Church of NZ. This denomination, which in 1924 absorbed the NZ Evangelical Mission, approached the Assemblies of God in 1932 with a view to amalgamation; however, their proposal was turned down. This situation was repeated in 1945 with the Assemblies of God again rejecting a similar proposal.

${ }^{79}$ Worsfold, History, 312-313. 
and who lived lifestyles that were not to the same degree "separated from the world." 80 The recollection of one New Zealand Apostolic Church minister was that the tarry meeting was replaced with "simple receiving, laying on hands (and coaxing)" with a resulting superficiality both in the experience of Spirit-baptism and in the accompanying expression of tongues. ${ }^{81}$

The theology of the charismatic is not identical to that espoused by Pentecostals and it should be noted that there is no unified charismatic theology to explain Spirit-baptism. ${ }^{82}$ One charismatic theologian, Wayne Grudem, has concluded ${ }^{83}$ that the doctrine of subsequence is harmful in that it effects a separation within the church into "ordinary" Christians and those who are Spirit-baptised. He notes that this tendency has exhibited itself throughout church history and has, in fact, been paralleled by distinctions of various types relating to levels of spirituality or commitment of the individual believer. Grudem believes that acknowledging the experience of Spirit-baptism "leads to jealousy, pride and divisiveness." ${ }^{\circ 4}$ His main concern is that the uninitiated will be jealous of their pneumatically endowed brethren. To accommodate such sentiment Grudem proposes a continuum of increasing maturity, intimacy and power within the Christian life.

Grudem's comments are representative of the charismatic viewpoint in that any "second work" automatically indicates a two stage Christianity. In an effort to eradicate any sense of there being two classes of Christian, some

\footnotetext{
${ }^{80}$ Blumhofer, Restoring the Faith, 270, points to the contact of US Assemblies of God adherents with charismatics as being something of a relief, in that they discovered tongue-speakers "could also embrace forms of modernity Pentecostals had long deemed sinful."

${ }^{81}$ Allen Arnold, letter to Luke Worsfold, 25 June 1997.

82 The term "charismatic" is rather fluid in meaning. With respect to origins, it can refer to those who owe their existence to the charismatic renewal and who either belong to "mainline" denominations or independent charismatic churches. With respect to theology, "charismatic" defines those who have experienced the Spirit while not necessarily holding to the theology of subsequence. The second nuance is employed here.

${ }^{83}$ Wayne Grudem, Systematic Theology: An Introduction to Biblical Doctrine (Leicester: IVP, 1994), 775-777.
} 
charismatically inclined theologians from Roman Catholic, Lutheran and Anglican denominations have developed the sacramental understanding of Spirit-baptism: the Spirit is received in baptism (usually infant) and is later actualised or allowed to come to consciousness. ${ }^{85}$ Charismatic evangelicals, while also viewing the Spirit's work as a unified experience, find the locus of Spirit-baptism in the moment of regeneration rather than the initiatory rite. The experience referred to by pentecostals as Spirit-baptism is therefore an "infilling" of the Spirit occurring in the ongoing process of sanctification. ${ }^{86}$ 84 In the same paragraph Grudem concedes that with respect to the Spirit-baptised being proud:
"It seems to me that most are not."
85 Kilian McDonnell, The Holy Spirit and Power: The Catholic Charismatic Renewal (New York:
Doubleday, 1975), 82. One problem with this viewpoint is that an infant is hardly to be regarded
as a believer and therefore cannot be initiated into the Christian faith. It follows that if there is no
initiation then there can be no "flowering" of the sacramental grace said to be received at that
time. Note that Larry Christenson, The Charismatic Renewal Among Lutherans: A Pastoral and
Theological Perspective (Minneapolis: Lutheran Charismatic Renewal Services, 1976), 37,
refers to Spirit-baptism as "a flowering or actualization of baptismal grace." Further, the
sacramental interpretation, with its actualisation schema, sees the Spirit as lying dormant in the
individual and does not recognise that God is doing a new thing in the life of the recipient.
Perhaps the biggest difficulty with the sacramental approach is that it does not fit with the record
in Acts, which nowhere describes water baptism as a rite where the Spirit is received.
86 Evangelicals, like Pentecostals, consider as true Christians only those who have been born
again, and describe as "nominal" those who lack this experience, irrespective of their
involvement or standing in the church. Evangelicals and Pentecostals have no difficulty with the
notion of categorising people as either "Christian" or "non-Christian." However, evangelicals
generally identify Spirit-baptism with conversion, the understanding being that all Christians are
baptised with the Holy Spirit. Thus, any further quest on behalf of a Christian to receive the
Spirit is seen as an undermining of salvation. Evangelicals repudiate any notion of an additional
work of the Spirit, most often it seems, on account of it being interpreted as a second stage or
higher echelon. Pentecostals, referring to Spirit-baptism as empowerment for mission,
encourage all Christians to receive it as an equipping, rather than an upgrade to a superior class
of Christian.

Sacramentalists put little emphasis on individuals undergoing the crisis experience of being born again. Given that individuals in this tradition are generally unable to point to a moment of conversion, the Spirit is assumed to be given via sacramental action. That is, the Spirit can either be given in the single rite of water baptism or, as in the case with denominations that practise confirmation, in the rites of baptism and confirmation which convey regeneration and the gift of the Holy Spirit respectively. Sacramental theology does not conceive of Spiritbaptism other than in connection with either water baptism or confirmation.

It may appear that sacramentalism has an ally in Pentecostalism in that, where confirmation forms part of the sacramental tradition, there is posited a work of the Spirit subsequent to regeneration. However, the allegiance is superficial: what separates is the fundamental understanding of what constitutes a Christian. To the evangelical / pentecostal mind there can be no rebirth without belief, hence "believer's baptism", the sacraments being unable to confer salvation. Sacramentalists find inherent power in the rites and consider recipients of any age Christians as a result. 
James Dunn describes Spirit-baptism as a "very definite and often dramatic experience" which forms part of the event of conversion-initiation ${ }^{87}$. In similar vein Michael Green affirms that Spirit-baptism is not an experience beyond conversion to be enjoyed by some, but rather "an initiatory experience for all Christians." ${ }^{88}$ Green, like Dunn, is not opposed to charismatic expression but is mightily concerned with elitism, which he sees as a necessary result of the subsequence doctrine, commenting that in the past "those who possessed the experience inevitably came to think of themselves as an 'in' group, the people who had arrived; and those who did not share that experience were, inevitably, regarded in some sense as second-class Christians" "89 Green's preference for a unified view, or perhaps more accurately his distaste for subsequence, is evident in his outright dismissal of Bennett's work and his praise of "thoughtful Christians within the Catholic charismatic movement" like McDonnell with whom he finds a level of agreement. ${ }^{90}$ The non-charismatic evangelical Packer likewise ties Spirit-baptism to conversion, and reasons that if "Spirit filledness" is not evidenced in Christians, then somehow they have been quenching God's Spirit. ${ }^{91}$ In his assessment of the charismatic renewal, the item that heads the list of negative aspects is "elitism." 92 It seems that

\footnotetext{
${ }^{87}$ Dunn, Baptism, 4. Non-charismatic evangelicals also describe Spirit-baptism in terms of the conversion event but are reluctant to attribute any charismatic element to it. This is the position represented by Hoekema who writes that Spirit-baptism "is not an experience distinct from and usually subsequent to conversion which every Christian ought to seek (the common NeoPentecostal interpretation), but is simultaneous with conversion and an integral aspect of conversion." Anthony A. Hoekema, Holy Spirit Baptism (Exeter: The Paternoster Press, 1972), 20.

${ }^{88}$ Michael Green, I Believe in The Holy Spirit (London: Hodder and Stoughton, 1975), 141-142.

${ }^{89}$ Green, I Believe, 126.

${ }^{90}$ Green, I Believe, 145

91 James I. Packer, Keep in Step With the Spirit (Leicester: IVP, 1984), 91.

${ }_{92}$ Packer, Keep in Step, 191. Lederle perpetuates this misconception in his book Treasures Old And New when he opines that pentecostal teaching views "Christians in the second stage ... [as being] . . . on a higher level in the eyes of God" (p. 5). He evaluates neo-pentecostal doctrine similarly, stating that Spirit-baptism places individuals "in a new state in the eyes of God" (p. 56). It comes as no surprise that Lerderle considers the neo-Pentecostalism/classical Pentecostalism difference to be "more one of degree than one of principle" (p. 218). Henry I. Lederle, Treasures
} 
many who oppose subsequence do so on the basis of combating the doctrine's perceived inherent elitism. ${ }^{93}$

Roman Catholics identify Spirit-baptism with Christian initiation, itself comprised of baptism, confirmation, and the Eucharist. However, the Spirit is given in confirmation which is seen as the completion of baptism. ${ }^{94}$ Pope Paul $\mathrm{VI}$ in the Apostolic Constitution on the Sacrament of Confirmation reaffirmed that in confirmation "those who have been born anew in baptism receive the inexpressible Gift, the Holy Spirit himself, by which they are endowed . . . with special strength." It is because the Roman Catholic Church understands Christian initiation to be an envelope of three sacraments that her theologians have to speak of that which is given in baptism as being "carried forward" by the sacraments of confirmation and the Eucharist. ${ }^{95}$ Although the terminology differs, most Roman Catholic theologians prefer to identify the pentecostal

Old and New: Interpretations of "Spirit-Baptism" in the Charismatic Renewal Movement (Peabody, MA: Hendrickson, 1988)

${ }_{3}$ It has gone unnoticed by the detractors that an elitism is evident in their own analysis, several works surveying pentecostal views then presenting "New Testament" or "biblical" teaching on the topic (e.g. Hoekema, Baptism; Bruner, Theology; Green, I Believe ). Interestingly, defenders of subsequence do not refer to themselves as belonging to a higher class, and maintain a nonscathing attitude towards those who do not share their theology. This sort of unilateral acceptance was very much evidenced during the so-called "Toronto Blessing" debate in New Zealand where advocates absorbed much criticism from those opposed to the phenomenon without reciprocating.

${ }_{94}$ Burkhard Neunheuser, Baptism and Confirmation, trans. John J. Hughes (Freiburg: Herder, 1964), 42, cites Acts 8:4-20; 19;1-7 and Hebrews 6:1-6 as endorsement for laying on of hands for impartation of the Spirit as a rite following and complementing water-baptism. Neunheuser (pp. 46-48) is able to conclude that while water baptism and laying on of hands are distinct events, they together complete Christian initiation. He refers to water baptism as "the first imparting of the Spirit" and the laying on of hands as the "complementary" imparting of the Spirit. For Neunheuser, Peter's command in Acts 2:38 is brought to realisation through these two components: it is the two rites together which "confer full membership in the fellowship of the disciples and impart the promised pneuma." Neunheuser does admit (p. 52) that initially both "tradition and St Paul speak of a single rite of initiation" and mentions the difficulty of tracing the beginnings of the "manner in which the Spirit was imparted in baptism and confirmation." It should be noted that any problem posed by a lack of Scriptural evidence for a doctrine can very often be solved by appealing to Tradition, which is worthy of receiving equal respect by a Roman Catholic.

${ }_{95}$ David Parry, This Promise is for You: Spiritual Renewal and the Charismatic Movement (London: Darton, Longman \& Todd, 1977), 57. Léon Joseph Cardinal Suenens, A New Pentecost? (Glasgow: Collins, 1977), 81, reports that those who have had a charismatic experience "esteem this grace as a revitalizing of the sacramental graces they have already received, conferred at baptism, then at confirmation, as well as at the reception of the other sacraments." Suenens' phrase "then at confirmation" does not adequately explain the 
Spirit-baptism as an actualisation of graces received in the initiation process. Noted Roman Catholic scholar Kilian McDonnell states that the Spirit given in initiation "emerges into consciousness" or is brought to "conscious awareness" in the charismatic experience. ${ }^{96}$

Charismatic Roman Catholic theologian Simon Tugwell affirms his church's position when he states: "The Spirit, the gift of new life in Christ, comes to us at baptism." However, he reasons that "what has been given may not mature all at once" laying out a vague scheme of repentance, humility and "prayer of the heart" as a way to experience what St Gregory of Sinai has referred to as the "manifestation of baptism." In explaining this delayed activation Tugwell, using the sacramentalist language, says that grace received in baptism is brought to "conscious effectiveness." "99

The increasing acceptability of pentecostal experience amongst the historic churches inevitably led to a degree of ecumenism that went beyond fellowship to the absorption of charismatic theology. Clergy from the historic churches were better equipped academically to theologise the experience of Spirit-baptism and quickly produced a body of literature that attracted a wide readership. Initially, the theology produced was neo-pentecostal: writers such as Larry Christenson (1968), Howard Ervin (1968), Steven Clark (1969), Dennis Bennett (1970), Rodman Williams (1971), Peter Hocken (1974) reflecting the

mechanism of the Spirit's action in linking baptism with confirmation, but he nonetheless wants to indicate a continuity of the Spirit's action in the two sacraments.

${ }^{96}$ Kilian McDonnell, ed., Presence, Power, Praise: Documents on the Charismatic Renewal (Collegeville, MN: Liturgical Press, 1980), 3:13, 32.

The Malines Documents, representing the deliberations of Roman Catholic theologians in Malines 1974, contained guidelines for the Roman Catholic charismatic renewal. Compiled by McDonnell, and published originally as Theological and Pastoral Orientations on the Catholic charismatic renewal and reprinted in Presence, Power, Praise, they distinguished between Spirit-baptism in a "theological sense" and an "experiential sense." The actual impartation of the Spirit equates to the theological sense whereas coming to conscious awareness of the Spirit is descriptive of the experiential.

${ }_{97}^{97}$ Simon Tugwell, Did You Receive the Spirit? (London: Darton, Longman \& Todd, 1972), 87.

${ }^{98}$ Tugwell, Did You Receive the Spirit?, 51-58. 
classical pentecostal position. ${ }^{100}$ However, charismatic theology soon followed, through the popular writings of: Kevin Ranaghan (1969), David Watson (1973), John Gunstone (1974), Thomas Smail (1975), Charles Hummel (1978), Christopher Moule (1978). Many of the new generation of Apostolic Church ministers assimilated charismatic thought via the readily available literature.

The effects of the charismatic renewal on the Apostolic Church in New Zealand continue to be felt, particularly in the shaping of theology with respect to Spirit-baptism. Initially, as we have seen, there was a sense of jubilation that the pentecostal truths championed by the movement since its inception were finally accepted by the wider church community. It was not long, however, before the Apostolic Church perceived inadequacies in the way those in the charismatic renewal received the Spirit i.e. without "tarrying" and the soulsearching normally associated with the exercise. To make matters worse charismatics, having received the Spirit, seemed to live at a lower level of personal holiness. ${ }^{101}$ Of major concern was the lack of regulation of spiritual gifts. The charismatic renewal had little regard for the recognition of present

\footnotetext{
${ }^{99}$ Tugwell, "Reflections on the Pentecostal Doctrine of 'Baptism in the Holy Spirit' 2" Heythrop Journal 13, no. 4 (1972): 406.

${ }^{100}$ Lederle, Treasures, 38 , notes that the initial attempts of charismatic theology were to simply appropriate classical pentecostal thought readily accessible via the popular market. Lederle's comment follows from his concern with subsequence which surfaces in the preface to his book where he states ( $p . x$ ) that the neo-pentecostal doctrine is "gradually superseded" by integrating into traditional Christian expression the "legitimate elements" of the renewal. He favours the interpretation which sees Spirit-baptism as a "highlight or milestone encounter" (p. 44). Here Lederle has unwittingly compromised his denial of a subsequent encounter given that a highlight or milestone must be identifiable. In trying to avoid there being two classes of Christian, Lederle forgets that his own experience of the Spirit was: "vivid;" bringing "a new dimension" to his faith; "transformational" (p. ix). This encounter obviously changed him; therefore, he was different beforehand. Lederle's purpose is clear in the statement that the highlight/milestone interpretation promotes the "full integration of charismatic insights into the whole congregation trying to avoid two classes of Christian" (p. 45). He is not opposed to the notion of "entries" or "comings" of the Spirit but only "once the two-stage grid has been disposed of" (p. 65). This is representative of the charismatic viewpoint which, while rejecting the pentecostal "second work," attests to an appropriation or actualization of the Spirit assumed to have been received at either regeneration or the initiatory rite. There is in this schema an implicit acknowledgement that some of the Spirit's work is not always immediately evident in the Christian. It fails to avoid the categorisation of believers into different levels insofar as those who have not had the experience of appropriating the gift of the Spirit can be identified as such.
} 
day apostles and prophets and this impacted on their approach to governance of the charismata. It was this view which presented a challenge to the system of church order employed by the Apostolic Church, a topic we will discuss in a later chapter.

\section{The Present Position}

Current positions on subsequence and associated doctrines amongst the movement's clergy display a range of thought. Philip Underwood, the Apostolic Church general superintendent from 1994 to 1997, initially preached the "with" then "in" theology which was passed on to him by Apostolic minister, Lex Cullen. Circa 1988, after studying F. F. Bruce's commentary on Acts, Underwood adjusted his understanding of Spirit-baptism to be that of a "mantling," reflective of the interaction between Elijah and Elisha, finding support in Luke's use of the "clothing" metaphor to describe the descent of power from on high (Lk 24:49). His reflections at the time were influenced by reading Gary B. McGee's Initial Evidence, Pneuma articles, theological papers by Apostolic ministers, and conversations with the Bible College of New Zealand's principal, John Hitchen. Underwood's concept of the ideal Christian experience would be one in which salvation and Spirit-baptism or "mantling" occur together, albeit in sequential order. Rather than seeing Spirit-baptism as an achievement, he prefers to talk of the mantling as enabling the believer, who received the Spirit at salvation, to be a "constant recipient of the power of the Spirit." Opposed to the tendency of Pentecostals to reflect nostalgically on their

\footnotetext{
101 See Doug Wead, Father McCarthy Smokes a Pipe and Speaks in Tongues (Dallas TX: Wisdom House Publishing Co, 1972).
} 
personal baptism as an event in the distant past, Underwood instead promotes constant infilling in order to operate with the Spirit's mantle and power. ${ }^{102}$

David Baxter was ordained in 1995, coming to the ministry from a background of physiotherapy training and clerical work. From about 1975 he had understood Spirit-baptism to follow salvation, usually after a significant separation in time due to what he saw as a "proving period." It was in the mid1980s, after exposure to a "Life-in-the-Spirit" seminar, ${ }^{103}$ that the influence of subsequence and the associated accent on tarrying diminished to the point where he could conceive of salvation and Spirit-baptism as "almost one event," rather like the encounter of Cornelius in Acts 10. However, he retained the foundational thought that faith must precede any bestowal of the Spirit. Baxter's concept of Spirit-baptism, at the time of writing, embraces more a charismatic viewpoint in that for him it is not a single event but rather a continuum in spirituality analogous to the path of salvation. Perhaps the greatest deviation from pentecostal theology is Baxter's belief that all of the Spirit is given at salvation and that the occasion referred to as Spirit-baptism is simply a release of that previously received. Progress along the continuum relates to the believer's appropriation of one or more of the yet-to-beawakened, but resident, spiritual gifts. ${ }^{104}$

Juxtaposed with the first point of view is that expressed by Donald Lake. A practising medical doctor until the early 1990s, he serves in the dual capacity of local pastor and prophet to the National Council of the Apostolic Church. His theology, very much shaped by his own experience, adheres to classical Apostolic doctrine. Lake explains the Spirit's action at regeneration in terms of

\footnotetext{
${ }^{102}$ Philip Underwood, interview with Luke Worsfold, Auckland, 7 November 1996.

103 "Life in the Spirit" seminars were produced by the Roman Catholic "Word of God" community at Ann Arbor, Ml to prepare their people for Spirit-baptism. However, they later became available to the wider church.
} 
the individual's spirit "coming alive toward God" evidenced by recognition of sonship, enablement to communicate spirit to Spirit, and awareness of divine transcendence or the supernatural quality of God. Baptism in the Spirit is described as the empowering of the believer with talents and imparted spiritual gifts. The experience involves the spirit, emotions and the body and consequently is physically validatable.

Lake's understanding was initially influenced by reading Layman's Commentary on the Holy Spirit. ${ }^{105}$ However his theology currently is somewhat contrary to his own experience yet not in opposition to it. Approximately a year after becoming a Christian he read Michael Harper's Power for the Body of Christ, praying the prayer printed at the end of the booklet whereupon he received an "inner witness of filling, outworked through an ability to resist temptation." The next step, in response to teaching received, was the quest for tongues as a devotional experience. This however proved to be a traumatic exercise, great anxiety arising due to the inability to receive the gift mixed with fear regarding the possible spurious nature of what might come. The consummation of the Spirit-baptism encounter came four years later while leading worship at a charismatic summer school in 1979 run by Christian Advance Ministries. Lake felt a prompting to "dance before the Lord."

From a survey of NZ Apostolic Church ministers in charge of assemblies in 2000 , it is evident that charismatic theology has been embraced to some degree. $^{107}$ A questionnaire sent to all ministers asked for an indication as to

\footnotetext{
${ }_{104}^{104}$ David Baxter, interview with Luke Worsfold, Wellington, 21 August 1996.

105 John Rea, ed., Layman's Commentary On The Holy Spirit: A Complete Analysis of the Person and Work of the Holy Spirit from Matthew to Revelation (Plainfield, NJ: Logos International, 1972)

${ }_{106}^{106}$ Donald Lake, interview with Luke Worsfold, 16 December 1996.

107 The Apostolic Church New Zealand had 100 pastors in a published directory in 2000, Apostolic News 20, no. 4 (2000): 8. A total of 116 pastors were surveyed which included other pastors listed in an Apostolic Church database. In that all staff were canvassed, the survey was
} 
whether they held to the doctrine of subsequence. A second question asked whether Spirit-baptism was an actualisation of a deposit received earlier, for example, at conversion. A final question enquired if the respondent's point of view had changed to or from the one currently held. Ninety-six per cent reported belief in the doctrine of subsequence, while only $60 \%$ supported the classical pentecostal belief that Spirit-baptism was a new work of God and not an actualisation of a previous deposit. Overall, approximately $25 \%$ had changed their viewpoint at some stage.

Of the $40 \%$ of those who accept the actualisation theory, nine respondents ( $23 \%$ of actualisation group) had changed their views to the one currently held; this means that the bulk of this group $(77 \%$ of the actualisation group) had not previously entertained classical pentecostal thinking. This is in contrast to the $60 \%$ who adhered to the traditional pentecostal view that Spiritbaptism is not an actualisation of the initiation experiences; here only one respondent $(1.7 \%$ of the non-actualisation group) indicated that his view had changed to the one currently held. Clearly, classical pentecostal theology is not having as great an effect as the newer charismatic doctrines in changing the thinking of Apostolic ministers, although at present a greater percentage still hold to traditional thought.

This effect can be traced to the academic training offered by the Apostolic Church. During the 1980s when John Douglas was principal of Te Nikau Bible Training College (then the national Apostolic ministers' training facility), nonpentecostal material was used, with the result that pentecostal distinctives,

more correctly a census. A response rate of $86 \%$ was achieved. See Appendix A below for a sample of the survey form. 
including the doctrines of subsequence and tarrying, were lost. ${ }^{108}$ This arguably reflects the theological background of Douglas, a former Baptist.

An antagonist to the subsequence theory can find Scriptural warrant to view water baptism as a single rite for both forgiveness of sin and Spiritreception. Four key texts that, in recent times, have been used to argue against this Pentecostal doctrine are ${ }^{109}$ : Acts $2: 38-41 ; 9: 17-19 ; 10: 44-47$ / $11: 15-18 ; 19: 1-6$. It is worth quoting these and outlining the arguments along with the defences offered by senior Apostolic Church ministers ${ }^{110}$ as they heavily affect the position of Pentecostalism within the Christian corpus.

i. Acts $2: 38-41$

${ }^{38}$ And Peter said to them, "Repent, and be baptised every one of you in the name of Jesus Christ for the forgiveness of your sins; and you shall receive the gift of the Holy Spirit. ${ }^{39}$ For the promise is to you and to your children and to all that are far off, every one whom the Lord our God calls to him." ${ }^{40}$ And he testified with many other words and exhorted them, saying, "Save yourselves from this crooked generation." ${ }^{41}$ So those who received his word were baptised, and there were added that day about three thousand souls.

Verse $41 \mathrm{a}$ is a terse report of those who responded to Peter's sermon: "So those who received his word were baptised". There being no explicit mention of the respondents receiving the Spirit, it is assumed that water baptism includes the gift of the Spirit. The apparent difficulties of this text did not strike the above-mentioned Apostolic Church sources during their years of ministry, neither was any treatment afforded in published literature of the church. A defence of subsequence by these leaders, in the light of such a reading of the text, either finds no significance in the non-reporting of Spiritreception in verse 41 or posits that the promised endowment occurred at a later

\footnotetext{
${ }^{108}$ Hone Maxwell, former Apostolic Church NZ national executive member, phone interview with C. M. Worsfold, 20 February 2001.

${ }_{109}$ Selected from F. D. Bruner, Theology, chap 5, 169-214. The remainder of Bruner's objections, from texts in Acts, are peripheral to the discussion and so have received no treatment here.
} 
time. To some extent this speculation reflects a predetermined theology, viz. subsequence. However, it must be remembered that the difficulty of the text may only be apparent when viewed through the interpretive grid of the nonPentecostal. Peter's incentive statement in verse 38, promising reception of the Spirit upon repentance and baptism, points to a logical distinction between conversion and Spirit-baptism. William Neil commenting on this verse writes that "repentance and baptism not only ensured God's forgiveness but his gift of the new power."111 There is no hint here that the Spirit was routinely bestowed in water baptism. If it were, the Samaritan Christians would have experienced the Spirit's filling (Acts 8:15-16). Jesus' statement contrasting John's baptism with that of the Holy Spirit (Acts 1:5) points to a firm separation of water baptism and Spirit reception. ${ }^{112}$

ii. Acts 9:17-19a

${ }^{17}$ So Ananias departed and entered the house. And laying his hands on him said, "Brother Saul, the Lord Jesus who appeared to you on the road by which you came, has sent me that you may regain your sight and be filled with the Holy Spirit." ${ }^{18}$ And immediately something like scales fell from his eyes and he regained his sight. Then he rose and was baptized, 19 and took food and was strengthened.

The account of Paul's conversion does not overtly attest to subsequence. From Acts 9:17 we know that Paul was told that he would receive his sight and be filled with the Holy Spirit. In the following verse Luke records that Paul regained his sight and was baptised, implying that water baptism is equivalent to filling with the Spirit if verse 18 is taken to be the full report of verse 17 . Historically, Apostolic leaders have handled this text by referring to Paul's

\footnotetext{
${ }^{110}$ See note 3 of the previous chapter for the names of those clergy consulted.

111 William Neil, The Acts of the Apostles, NCBC, ed. Matthew Black (Grand Rapids, Ml: Eerdmans, 1973), 79.

112 The sacramental tradition teaches that the Spirit is given in the sacrament of water baptism whether or not the baptisand is even aware of it. James Dunn scrutinises the sacramental approach in his Baptism, an endeavour not obvious from the slightly misleading sub-title, "A Reexamination of the New Testament Teaching on the Gift of the Spirit in Relation to Pentecostalism Today."
} 
testimony concerning tongues in I Corinthians $14: 18$, while recognising that a stronger case would arise from an explicit mention in the Acts passage, indeed even wishing it were so. ${ }^{113}$ Joshua McCabe, an Apostolic Church pastor in Australia who wrote on evidence of the baptism in 1952, referred to the nonrecord concerning the Samaritans and then stated: "Paul receives the Holy Spirit, and again no record of tongues is given at the time, but Paul has stated in 1 Corinthians 14 verse 18, "I thank my God I speak in tongues more than ye all!"114 In Rowe's treatment he steps over the problem of the text failing to provide evidence for subsequence by instead highlighting Paul's Spirit-filling and tongue-speaking and assuming their coincidence:

It is not questioned that Ananias had a share in the divine plan and ministry, in Saul receiving the Baptism, or Filling of the Spirit, whether it was at that time, or on a later occasion. Concerning this point there is no inspired record, and actually it is not important WHEN he received the great Gift. We do know for certain, that Saul (or Paul) did receive the Baptism of the Holy Ghost with the supernatural sign of speaking in other tongues (I Cor. 14:18). ${ }^{115}$

iii. Acts 10:44-47

${ }^{44}$ While Peter was still saying this, the Holy Spirit fell on all who heard the word. ${ }^{45}$ And the believers from among the circumcised who came with Peter were amazed, because the gift of the Holy Spirit had been poured out even on the Gentiles. ${ }^{46}$ For they heard them speaking in tongues and extolling God. Then Peter declared, "47"Can any one forbid water for baptizing these people who have received the Holy Spirit just as we have?"

\section{Acts 11:15-18}

${ }^{15}$ As I began to speak, the Holy Spirit fell on them just as on us at the beginning. ${ }^{16}$ And I remembered the word of the Lord, how he said, "John baptized with water, but you shall be baptized with the Holy Spirit." ${ }^{17}$ If then God gave the same gift to them as he gave to us when we believed in the Lord Jesus Christ, who was I that I could withstand God?" ${ }^{18}$ When

\footnotetext{
${ }^{113}$ Not all the interviewed sources could recall being aware of the difficulty in the text and once alerted to this perspective on the conversion story found little significance in it. One source assumed a delayed Spirit-baptism for Paul and in this found the practice of "tarrying" normative. The one text-critical explanation advanced was that Luke was using documents and may not have had access to any further information.

${ }^{114}$ Joshua McCabe, "The Baptism of the Holy Spirit" in The World 7, no. 4 (1952): 9.

${ }^{115}$ Rowe, Pattern, 55-56.
} 
they heard this they were silenced. And they glorified God, saying, "Then to the Gentiles also God has granted repentance unto life."

The Cornelius story provides support for the doctrine of tongues-speaking as an initial evidence of Spirit-baptism but contributes nothing to the argument for subsequence. In fact, Peter's explanation of his actions to the believers in Jerusalem is cited by critics as further evidence of Spirit-reception being synonymous with salvation. In Acts 11:15-18 Peter recounts the coming of the Spirit on Cornelius' household and describes how he equated what he saw with the Lord's promise of being baptised with the Holy Spirit, recognising the encounter as the same gift given to himself earlier. Peter's hearers conclude (v. 18) that God has granted the Gentiles repentance unto life. Here a comparison of the events described by Peter (the Holy Spirit falling) with the summation offered by his hearers (Gentiles granted repentance) allows for the conclusion that Spirit-baptism and repentance unto life are one and the same event. $^{116}$

The Apostolic Church's understanding has been that because Jerusalem was unable to accept the legitimacy of Peter's encounter with the Gentiles, they having "criticized" him (v. 2), the confirmation they needed regarding the Gentiles' salvation was the latter's Spirit-reception. This explains their response in verse $18 .^{117}$ McCabe, in his above-mentioned article on the evidence of the baptism in the Spirit, maintains that the sign of the Spirit's presence is "that He shall speak. He is no dumb spirit! Peter made this great plea when he was

\footnotetext{
${ }^{116}$ Alternatively, Luke is using the Spirit falling as post facto evidence for repentance unto life.

${ }^{117}$ It is worthwhile noting at this point that if the prerequisite for receiving the Spirit is repentance then the visible effects of the Spirit's descent pointed to the more fundamental and indispensable salvation event and this is what the Jerusalem believers recognised from Peter's account. It is possible that this primacy of salvation is what Luke wanted to convey in his reportage of Peter's sermon and Paul's conversion. In both cases the Holy Spirit was promised in conjunction with a more basic event, viz. repentance and receiving sight respectively. The mention of baptism (in water) is the common element in the two summaries (Acts 2:41; 9:18). Bearing in mind that first century baptism was linked closely in meaning and time to salvation, it is clear Luke wanted to highlight the salvific experience.
} 
called to account for giving the Gospel to the Gentiles."118 McCabe, writing two years later on evidence of Spirit-baptism, stated:

Let us notice here what it was that convinced them that the Holy Spirit had fallen on the Gentiles. Owing to their Jewish prejudice it would require something very remarkable indeed to convince these men of the circumcision, who came with Peter, that the Gentiles had received the Holy Spirit, as the church had not yet been made to see that repentance unto life and the gift of the Holy Spirit were for the Gentiles as well as for the Jews. ${ }^{119}$

It was this line of reasoning, here applied to Peter's travelling companions, that was employed when treating the later event of the apostles' challenge to Peter. That is, due to an elitist mentality nothing short of Spirit-baptism would convince them. After all, as McCabe observes, it required a heaven-sent vision before Peter could respond positively to Cornelius' request. ${ }^{120}$ On the technicality of subsequence, it was proposed by our interviewed sources that in this case salvation and Spirit-reception were separated fractionally in time. It was never ventured that the two events were coincident. It was readily noted that this account illustrates a reversal of the usual order of water baptism preceding Spirit-reception.

iv. Acts 19:1-6

${ }^{1}$ While Apollos was at Corinth, Paul passed through the upper country and came to Ephesus. There he found some disciples. And he said to them, "Did you receive the Holy Spirit when you believed?" 2 And they said, "No, we have never even heard that there is a Holy Spirit." ${ }^{3}$ And he said, "Into what then were you baptized?" They said, "Into John's baptism." "And Paul said, "John baptized with the baptism of repentance, telling the people to believe in the one who was to come after him, that is, Jesus." ${ }^{5}$ On hearing this, they were baptized in the name of the Lord Jesus. ${ }^{6}$ And when Paul had laid his hands upon them, the Holy Spirit came on them; and they spoke with tongues and prophesied.

The fact that when Paul was confronted with non-pneumatic believers he investigated their water baptism, points to his presupposing that this rite and

\footnotetext{
${ }_{118}^{118}$ McCabe, "The Baptism of the Holy Spirit" in World 7, no. 4 (1952): 16.

${ }^{119}$ McCabe, "Speaking in Tongues: The Evidence of the Holy Spirit Baptism" in World 9, no. 5 (1954): 24.
} 
receiving the Spirit go together. ${ }^{121}$ This interpretation had previously been brought to the attention of the interviewed group either from their own observation or via reading interpretations of non-Pentecostals. ${ }^{122}$ The usual treatment of this stance was to postulate that Paul detected an inadequacy in the Ephesians' spiritual endowment and before he would exercise the ministry of laying on of hands he sought assurance that they were already water baptised. This line of thought reflects the Apostolic belief in the usual order of the Spirit's work, viz. regeneration, water-baptism, Spirit-baptism.

A related point in the discussion is whether the Ephesian disciples were in fact Christians as opposed to followers of John. If the disciples ( $\mu \alpha \theta \eta \tau \dot{\alpha} \varsigma)$ had never possessed faith in Jesus but in a Messianic figure to follow John, then Paul's message is one of salvation. Their failure to receive the Spirit when they "believed" is a result of whom they were believing in. So runs the argument against subsequence. However if the disciples did have faith in Jesus, albeit an incomplete faith, then their experience of the Spirit is very clearly one differentiated from salvation. ${ }^{123}$ The Apostolic Church has remained convinced of the Christian status of the Ephesian believers. This was the response of the interviewed group and the evidence from the published material. Referring to

\footnotetext{
${ }^{120}$ McCabe, "Speaking in Tongues," World 9, no. 5 (1954): 24.

121 This is the view taken by Bruner, who finds support from a number of scholars, mostly German. See his Theology, 208, n. 60.

${ }^{122}$ The reference to this text in the Apostolic Church published material is always with respect to Christians receiving the gift of the Spirit.

${ }^{123}$ This text provides no real difficulty for classical pentecostal doctrine when it is noted that for Paul to even ask his first question the possibility of belief in Jesus without receiving the Holy Spirit must exist. Bruner, Theology, 208, n. 59, admits this observation made by CerfauxDupont but denies its applicability on account of the remainder of the narrative. However, Bruner is making two assumptions. The first (p. 213), is that the disciples were not Christians: "The Holy Spirit in Acts 19 had not made a 'first entry', he had not yet come at all (v. 2). There is no second experience of the Holy Spirit in Acts 19." The second (p. 211), is that the coming of the Spirit was coincident with their water baptism together with the laying on of hands: "There was probably never a baptism unattended, and rarely one in which the administrant did not prayerfully lay his hands on the baptized person. The laying on of hands probably constituted the conclusion of the baptismal act."

Paul's second question may have been prompted by a guess that the trinitarian formula was not used in their baptism, indicating an ignorance of the Holy Spirit.
} 
the Holy Spirit of promise mentioned in Eph 1:13, T. N. Turnbull writes: "Belief must precede the reception of this great gift. These Ephesian believers were baptised in water, and then hands were laid on them for the baptism of the Holy Spirit, and they spake with tongues and prophesied (Acts 19:1-6)."124 British Apostolic minister David Rennie, expounding the "Gift of the Holy Spirit," had this to say:

Surely the Apostles were regenerated men before Pentecost, yet they had not been indwelt by the Holy Spirit. . . . All will concede that the Spirit-filled evangelist Philip would never have baptized unsaved people. But not until verse 17 do we read of their receiving the Holy Spirit. Acts chapter nineteen bears similar testimony. Following Paul's query, his testimony and his ministry, the Ephesian disciples became baptized believers (v. 5). Then in verse six they experienced the incoming presence and power of the Holy Spirit. ${ }^{125}$

This encapsulates the distinctive doctrine of classical Pentecostalism. However, it seems that Pentecostalism as portrayed in the New Zealand Apostolic Church is now less concerned with theology than it is with praxis. Over the last decade, the focus in the national publication, Apostolic News, has been on church growth and mission. ${ }^{126}$ Little, if any, theological writing currently emanates from the Apostolic Church yet there is much theology within her own archives and in published academic journals which invites interaction. The sermons of yesteryear contained much theologising with a heavy reliance on Scripture, but this has given way to the inspirational and motivational talk.

\section{Summary}

The Apostolic Church adheres to the doctrine of subsequence, believing that the pneumatological experience of New Testament christians as Luke

\footnotetext{
124 Thomas Napier Turnbull, What God Hath Wrought: A Short History of the Apostolic Church (Bradford: Puritan Press, 1959), 156.

${ }^{125}$ David Taylor Rennie, The Gifts of the Holy Spirit (Bradford: Puritan Press, 1967), 19.

126 These emphases are not new to the Apostolic Church, being present in the core establishment of the movement.
} 
describes it is a prototype for the present day. Modern pentecostal scholarship agrees that Luke intended to promote a work of the Spirit distinct from salvation and, as a result, validates the patterning of contemporary experience on the Acts accounts. Early Apostolics, without the theological and exegetical skills now evident amongst pentecostals, put forward a number of theologies to explain the mechanism of subsequence, but these constructions have not persisted.

If the doctrine of subsequence is accepted then the question of tarrying arises. The Apostolic message concerning Spirit-baptism was first delivered primarily to evangelicals, hence the main thrust at that time was encouragement to seek, and instruction on how to receive the gift. The disciples' wait in Jerusalem for the coming of the Spirit provided the rationale for the idea that seekers for the gift of the Spirit were required to tarry. However, a closer look at the doctrine shows that it was not the time per se that was required, rather what transpired in the process. The preparation undertaken by the seeker was misconstrued by detractors as fulfilling "conditions" and, as such, a deviation from the "faith alone" maxim. The answer to the charge lies in viewing the preparations as expressions of faith or responses, similar to the way responses of faith, repentance and confession are required for salvation.

The issues of subsequence and tarrying faced challenges from, and have been influenced by, the Latter Rain and the charismatic renewal. The denominational structure of pentecostals in general and the centralism of the Apostolics in particular were targets of criticism by Latter Rain proponents. They advocated local autonomy and the expression of five-fold ministry within each congregation: locally appointed apostles began imparting the gift of the 
Spirit via the laying on of hands and all without any hint of tarrying. These apostles itinerated free of any national governing body, a feature which disturbed Apostolic Church leaders. The Latter Rain, therefore, undermined the Apostolic position which held to the necessity of tarrying to receive the Spirit.

The charismatic renewal, likewise, had a significant effect on pentecostal theology, only with this later phenomenon a more fundamental doctrine was affected, viz. subsequence. Initially, the charismatics adopted pentecostal theology and as a result were dubbed "neo-pentecostals." However, charismatic theology emerged as the academically-trained ministers from the historic churches set to work to explain their experience of Spirit-baptism. Charismatics view Spirit-baptism as either an actualisation of sacramental graces (the sacramental position) or the ongoing process of sanctification in the believer (the evangelical position). These theologies were widely available and there is evidence that later generations of Apostolic Church ministers incorporated charismatic thinking into their own.

Not only did charismatics not tarry for the gift of the Spirit, they understood the experience differently; it was not a second work of grace and there is not, implicit in this theology, a sense that God is doing something new in the life of the believer. Pentecostals attribute a far greater theological and practical significance to Spirit-baptism. Compared to pentecostals the manifestations and sequelae of the event experienced by charismatics were more subtle.

Given that Spirit-baptism is a gateway to spiritual gifts, of which prophecy is paramount, it seems that the de-emphasis on the baptism resulting in a "shallow" experience consequently leads to a weaker expression of the gift of prophecy. This is problematic in that the Apostolic Church is unique among 
pentecostals in recognising the present-day office of prophet, with a particular outworking through church government. It is to this spectacular manifestation of the Spirit, viz. prophecy, that our attention is now drawn. 


\section{CHAPTER FOUR}

\section{PROPHECY}

The ordination of D. P. Williams by W. O. Hutchinson in 1910 was in response to a prophecy. Hutchinson and his assistant, James Dennis, visited Penygroes and while there Dennis prophesied that Williams should be set apart to the ministry; Hutchinson acted immediately, laying hands on Williams and ordaining him as a pastor. The visit to Penygroes was itself the result of prophetic instruction, via a prophetess in London. ${ }^{1}$ The Evangelistic Church in Penygroes, where Williams was involved, did not immediately sense the need for a pastor and so continued to be governed by its presbytery; however, it was prophecy via members of the congregation which eventually led to his appointment being affirmed. ${ }^{2}$ The following year Williams received a prophetic word which instructed him to seek out his backslidden brother, Jones Williams, and deliver him a specific warning and a promise concerning the future. This he did and Jones responded positively, himself later becoming a recognised prophet in the Apostolic Church. ${ }^{3}$ A rift developed in the Evangelistic Church over the issue of pentecostal leadership and when a lock-out isolated D. P. Williams and his supporters in 1913, it was prophecy that provided direction and encouragement for the future. ${ }^{4}$ In 1914 , during the Apostolic Faith Church

\footnotetext{
${ }^{1}$ James E. Worsfold, The Origins of the Apostolic Church in Great Britain: With a Breviate of Its Early Missionary Endeavours (Wellington, NZ: Julian Literature Trust, 1991), 21.

2 Thomas Napier Turnbull, Brothers in Arms (Bradford: Puritan Press, 1963), 36.

${ }^{3}$ Turnbull, Brothers, 37-38.

${ }^{4}$ Rees Evans, Precious Jewels from the 1904 Revival in Wales (n. p., 1962), 9.
} 
convention in London, prophecy identified Williams as an overseer and apostle of the Welsh AFC congregations and he was ordained as such immediately. ${ }^{5}$

Williams had been considered Hutchinson's right-hand man until a prophecy in 1915 indicated that, with regards to the Apostolic Faith Church, Scotland now stood next to England; as a result Williams and the Welsh congregations he represented lost their position of favour. ${ }^{6}$ Prophecy featured in the secession of the Welsh congregations from the Apostolic Faith Church in 1916. Given that the mind of the Lord was made known through prophecy, Williams' later written remark, "the Lord desires us to sever this connection," must refer to prophetic utterance which guided their action. ${ }^{7}$ Considering the position of Jones Williams in the Welsh congregations, it is understandable that he was the channel through which such revelation came. ${ }^{8}$

The practice of "enquiring of the Lord through the prophet" was no less popular in the Apostolic Church as it had been in the Apostolic Faith Church, although the conditions for its use were eventually regulated. In 1946 D. P. Williams was in Baltimore, MD, when news came that his daughter was seriously ill back in England. He "enquired of the Lord" via J. D. Eynon only to discover that he himself would not die away from Wales. However, on the voyage home he developed pleurisy and pneumonia and looked certain to die; Williams' wife recalled the prophecy and was assured that he would not die at sea. Indeed, he was reunited with his family and died in Penygroes several weeks later.

\footnotetext{
${ }^{5}$ W. O. Hutchinson, ed. Showers of Blessing, no.12:11.

${ }_{7}^{6}$ Worsfold, Origins, 119.

7 D. P. Williams, Souvenir Exhibiting the Movements of God in the Apostolic Church (Penygroes: Apostolic Church Publications, 1933), 9.

${ }^{8}$ Worsfold, Origins, 152. Worsfold records that Jones Williams, while standing with his brother and three other AFC ministers on the footpath after a service in the Bournemouth August conference, prophesied that the time was approaching when their contemplated action should occur.
} 
Prophecy formed a fundamental element of Williams' spirituality. It seems that at every significant juncture in his personal life the divine utterance guided him. In his ministerial capacity, response to, and exposition of, prophecy was a primary objective. He was renowned for his insightful expository comment following a word of prophecy and Riches of Grace published many such expositions on prophecy brought during Penygroes conventions. A compilation of Williams' editorials on prophecy were published as a monograph by the Apostolic Church International Council in 1931 under the title The Prophetical Ministry (or the Voice Gifts) In the Church. Williams distinguished between the prophetic spirit, gift and office. The spirit of prophecy may rest occasionally upon individuals; the gift permanently abides; and the office of prophet operates in a universal governmental role. In this, Williams perpetuates doctrines he embraced in the Apostolic Faith Church. ${ }^{9}$ In delineating the scope of the gift of prophecy Williams reiterates St Paul's trio of edification, exhortation and comfort. However, the office of prophet, according to Williams:

Rises higher in Church government in ministry and operation, expounding deep mysteries, and possessing the power to unravel the deep things of the Law, the Prophets and Psalms, magnifying and taking from the Christ things concerning His Person, and His mystical life dwelling in His Body, making known the predestined Will of God, giving the most inexhaustible wealth out of His store in the things of God ${ }^{10}$

It is interesting to note that Williams reinforces the governmental role, which must include identifying the will of God, but highlights the action of receiving revelation with descriptions of expounding, unraveling, and magnifying the knowledge of God. While prophecy was used to direct the administrative affairs of the church, theological elaboration formed the major component of prophetic utterance. In the appendix to Prophetical Ministry Williams included transcripts of four prophecies, each on different topics, from ordained prophets

${ }^{9}$ Showers, no. $12: 11$, records that at the same meeting where he was called via prophecy to be an apostle, others were called to the office of prophet. 
of the Apostolic Church. The themes of God's loving-kindness, the Second Coming, efficacy of the Communion service, and dispensations formed the selection and the designation "The Word of the Lord" appeared at the top of each transcript.

However, prophecy did not rule the church. In the same publication Williams borrows from an unnamed source in utilizing the metaphor of the hand to represent church government. The "index finger of prophetic ministry" is directional in nature in that it points the way, but is itself controlled by the thumb which represents the apostles who provide wisdom and judgement of divine revelation. ${ }^{11}$ In his previous chapter, Williams plainly states that prophets do not have authority in the church and, in an obvious endorsement of the church authority structure, follows this comment with the pronouncement that "church government is the protection for the prophetic operation." He then pointed to the lack of subjection to the church presbytery as one factor which caused Baxter, the Catholic Apostolic Church prophet of the previous century, to recant and deny that his own prophecies were in fact from God. Williams generalized, stating that a gift imparted by the Spirit will "be found unprofitable" if the one operating in the gift will not be "ruled and guided by ordinations" which have been established in the church for that purpose. He drew an analogy between light and judgement, brought by the prophet and apostle respectively, and the urim and thummim of the high priest's breastplate. That is, they are inseparable and interdependent; the revelation via the prophet is evaluated and expounded by the apostle. ${ }^{12}$

Williams also noted four other purposes of the twin office of apostle and prophet: (i) evidence of God's spirit indwelling the body of Christ, with

\footnotetext{
${ }^{10}$ Daniel Powell Williams, The Prophetical Ministry (or the voice gifts) In the Church (The Apostolic Church: Penygroes, 1931), 87.

${ }_{11}^{11}$ Williams, Prophetical Ministry, 88.

${ }^{12}$ Williams, Prophetical Ministry, 80-81.
} 
Ephesians 2:22 \& Psalms 68:18 quoted in full; (ii) protection of the church from human deceit; (iii) perfection of the church, work of the ministry and edification of the body of Christ; (iv) unity of spirit, faith, knowledge and love, with Ephesians 4:12-16 referenced. ${ }^{13}$ These four are not elaborated further but it is interesting to observe the particular use of Ephesians 2:22.

Williams, although an apostle, was known to prophesy. Given that cofunctioning of the apostle and the prophet is to yield evaluation and exposition of prophetic words brought forth, it is to be expected that a certain familiarity with the mechanism of prophecy should be the possession of an apostle. The first transcript of a prophecy from Williams appeared in a 1920 edition of Riches of Grace. It was a mature prophecy most obviously because it commented on the spiritual state of Britain, lamenting her self-defilement and desecration of the Lord's name. Further evidence of the weight of the prophecy is that it carried both promise and warning, conveying God's intention to give the "priesthood of the Lord" to the undefiled while abandoning the defiled to their own way. Christians were challenged to distance themselves from those things which defile. In addition, there was clear instruction to avoid building with "untempered mortar" because it will not hold the stones. ${ }^{14}$ The revelatory element was apparent in identifying purity of heart as a catalyst to removing obstacles and reminding that God's work is dependent on his perfection and not human imperfection. Another strong indicator of the weight of the prophecy was the predictive assertion that God "will visit" resulting in the response of many people. $^{15}$ Clearly, Williams operated with authority in the realm of prophecy: his utterance was not of a puerile nature, reminding hearers of the obvious, or merely paraphrasing Scripture; rather, it had the hallmarks of significant

\footnotetext{
${ }_{13}^{13}$ Williams, Prophetical Ministry, 87-88.

${ }^{14}$ The tempered mortar and stones presumably represent strengthened Christians and converts respectively.
} 
revelation. He possessed more than a modicum of ability to prophesy, further establishing his credential to evaluate and expound prophecy.

Exposition of prophecy, however, remained Williams' main contribution. He was not content to simply reword or restate a prophecy but would provide a rich commentary amplifying selected phrases. The exposition generally followed the prophecy (or prophecies) and, apart from notes made during the prophecy, was delivered extemporaneously. Williams consistently made use of analogous biblical examples to explain the background to a situation or prescribe an appropriate course of action or to elaborate a theological truth. The depth of analysis offered on each point was frequently tantamount to a sermon outline and is a reflection of Williams' knowledge of Scripture and ability to formulate ideas quickly.

\section{The Nature of Prophecy}

It is apparent from his writing that Williams retained something of Hutchinson's view on the infallibility of divine utterance, ${ }^{16}$ stating in Prophetical Ministry that prophecy is "a Divinely generated utterance through human lips by the indwelling Spirit of God"17 and as the "Voice of God . . . convey[s] the Mind and Disposition of God." ${ }^{18}$ In a later chapter he cautioned against considering "every word" uttered by developing channels to be inspired; by implication the words of mature channels are $100 \%$ inspired. $^{19}$ Elsewhere in his monograph Williams describes the action of God in prophecy as "the Divine Mind coming down possessing human channels, using their vocal organs, making use of

\footnotetext{
${ }^{15}$ Riches of Grace 1, no. 9 (1920): 20-21, records prophecy spoken at the Lesser Town Hall, Pontypridd, 26 December 1919.

${ }^{16}$ Williams, Prophetical Ministry, 121. The position of the AFC is exemplified by a James Hutchinson-Dennis article which states that "there is no difference at all" between the written and spoken word, they are both the "Word of God." Showers, no. 14:4.

${ }_{17}$ Williams, Prophetical Ministry, 7.

${ }^{18}$ Williams, Prophetical Ministry, 15.

${ }^{19}$ Williams, Prophetical Ministry, 33.
} 
human language and tongue." ${ }^{20}$ This attributing of $100 \%$ divinity to prophecy is a probable reason for the prophetic idiom mimicking the language of the King James Version, the standard Bible translation of the time, considered to be the infallible, Divinely inspired word of God. ${ }^{21}$ Sermons, or Bible readings as they were called, did not have the same stylistic dependence on the King James Version, however they often exhibited an ornate quality.

At the 1925 Penygroes convention Williams said that "the gifts of the Holy Spirit in themselves are infallible." In the next sentence he broadened the concept to "every gift of God is infallible" and referred to the event of being born again as an example of a gift of God which cannot be marred, despite any display of carnality by the receiver. In other words, the nature of the gift is perfect but the godliness or otherwise of the channel is self-determined. It is in this context that Williams, while presenting prophecy as a totally divine operation where the channel is something of an automaton, addresses the situation of a prophet knowingly speaking words that do not emanate from his gift. In this he is affirming the authenticity of the gift while at the same time acknowledging the possibility of error on account of the state of the practitioner:

Prophecy is a gift in the bowels of a prophet and is perfect. It cannot be touched by a subconscious or a conscious mind, but the prophet who has the infallible gift of the Holy Spirit in him, if he gives forth words that were not from that gift, knows that he is doing it. ${ }^{22}$

He showed the Lord's response to such action to be commensurate with the attitude of the prophet, quoting from Psalm 18:26 to demonstrate his point. A similar tension is apparent in the Constitution, ${ }^{23}$ under the heading "Infallibility

\footnotetext{
${ }^{20}$ Williams, Prophetical Ministry, 66-67. This has not proved to be a lasting position within the Apostolic Church. Neither was this thought absorbed into the thinking of the charismatics who were to follow. Roman Catholic charismatic Bruce Yocum, Prophecy: Exercising the Prophetic Gifts of the Spirit in the Church Today (Ann Arbor: Servant Books, 1993), 21, finds that "genuine prophecy is both a divine and human activity."

${ }^{21}$ The language of religious rites in liturgical churches at the time also reflected "King James English."

${ }_{22}$ Riches of Grace 3, no. 1:73-74.

${ }^{23}$ The Apostolic Church: Its Principles and Practices (The Apostolic Church: Penygroes, 1937). This one volume publication comprised three parts: (i) the constitution for the British
} 
of Prophetic Utterances." This entry, in a sub-section of the guiding principles devoted to the subject of prophets, discouraged the teaching that the prophets were infallible but outlined criteria which, if met, would enable a prophecy to be considered the infallible word of God:

(a) where the prophet is a chosen and predestined vessel in the Body of Christ; (b) when he is living in holiness, humility and obedience; (c) when he is responsive to the movings of the Holy Ghost within him.

Many entries in the guiding principles were supported by an excerpt from prophecy and the above criteria were similarly endorsed: "I declare the prophet himself, the vessel himself is not infallible; but that which I, the Lord, have given is infallible." ${ }^{24}$ All three criteria are subjective to some extent, although ordination as a prophet would presumably identify one as "chosen and predestined." The question does arise as to how any measurement of criteria (b) and (c) was made. While these questions will remain unanswered for the time-being, it can be said that prophecy was considered to be divine in origin and so any utterance not reaching the inspired level must signify a failure on the part of the prophet to live a godly life. There is no indication at all that prophecy was a cooperation of the Divine and human minds and this is borne out by the many statements that attribute the origin of prophetic utterance to be entirely with God. ${ }^{25}$

In his monograph Williams presented some discussion on the biblical words for prophet ('Nabi'), seer ('Roch'), and the Greek word for trance

\footnotetext{
Isles, (ii) the guiding principles for the Apostolic Church, (iii) the overseas constitution. The overseas constitution closely followed that of the British Isles and the guiding principles expounded the fundamental truths (tenets) of the Apostolic Church and contained an additional section treating the topics of: calling, ordination and character of church officers; assembly administration; divorce; discipline. The volume bore the imprimatur of D. P. Williams: the foreword was written by Williams and a copy of his affidavit declaring the document presented as the constitution, preceded the first part.

${ }^{24}$ Principles and Practices, 225. The particular prophecy was uttered in Glasgow in September, 1928.

${ }^{25}$ The corollary to this viz., the equivalence of prophetic utterance to Scripture, ceases to be a difficulty if prophecy is instead understood to be a divine-human mix. One theology which nonetheless undermines any allegation of over-valuing prophecy is the "logos/rhema"
} 
('ekstasis'). He concluded that the biblical seers of God, while entranced, were "possessed and enveloped by the Holy Spirit, and thereby were made the observers and revealers of the hidden mysteries of God." 26 He claims that the prophets of the Old Testament were "ignorant . . . of the Substance of the words which were uttered by the Spirit through their own lips." To substantiate this, Williams quotes II Peter 1:21 which states that no prophecy ever came at man's instigation but rather by movement of the Holy Spirit, and paraphrases I Peter $1: 10-12$ which describes the search by the prophets as to the person and time their predictions referred to. The purpose of his essay at this juncture seems equally to demonstrate the Divine nature of prophecy and its purpose as revealing the "Eternal Life and Substance." 27

Two categories of biblical prophecy are identified by Williams: those of a circumstantial nature which edify, exhort and comfort, after the manner of I Corinthians $14: 3$, and those of the higher order which reveal God's plans and purposes. A contemporary prophet may begin to speak "on a low plane" that is, addressing circumstance but, with more empowerment by the Spirit, move into a higher level of ministry and bring a revelation of God to man. In general terms, this higher order prophecy displays a "cauterizing influence" characterized by wisdom and inner searching. ${ }^{28}$ The benefit for the hearer of this level of prophecy is: inner searching, a recognition of personal weaknesses, conviction, revelation, transformation, healing, soothing, and the combined actions of restoration and improvement. Williams believed that

distinction. "Rhema" refers to revelation which is specific, temporal and subjective whereas "logos" describes the Bible which is general, eternal and objective.

${ }^{26}$ Williams, Prophetical Ministry, 12.

${ }^{27}$ Williams, Prophetical Ministry, 15.

${ }^{28}$ More recently the Anglican charismatic Joyce Huggett, Listening to God (London: Hodder \& Stoughton, 1986), 133, has described three levels of prophecy: "low-level" which reminds the listener of rudimentary truths; "higher-level" where situational details specific to a given church are revealed; "highest-level" which evokes a worship response due to audience awareness of the divine origin of the utterance. See also, G. Mallone ed., Those Controversial Gifts (London: Hodder \& Stoughton, 1984), 44. 
application of biblical truth combined with the power of prophecy was an experience never to be forgotten. ${ }^{29}$

Williams used analogies of the telescope, spectroscope and camera to describe contemporary prophetic ministry in terms of three expressions of vision. In one mode prophecy looks far into the distance; in another it analyses the quality and composition of men, ministry and events; and in yet another it conveys detail of pictures which unveil the plan of God. ${ }^{30}$ Here the emphasis appears to be less on discovering the nature of God than it is on finding his plan and purposes, which is of primary concern for Spirit-led individuals and congregations alike.

\section{The Function of Prophecy}

It is apparent that Williams perceived prophecy to be an expression of the mind of God. He does not categorise prophecy into that which elaborates the nature of God and that which unveils his plan, and this is valid given that the purposes of God for his people reflect his nature. However, such a delineation describes a functional difference which is both useful for this study and forms an identifying characteristic of the role of prophecy in the Apostolic Church: many pentecostal churches encouraged prophetic expression, but the Apostolic Church recognised the office of prophet and its role in church government. ${ }^{31}$

\footnotetext{
${ }^{29}$ Williams, Prophetical Ministry, 65-66.

${ }^{30}$ Williams, Prophetical Ministry, 63-64.

${ }^{31}$ The Apostolic Church's closest relative, the Assemblies of God (AoG), has never embraced the concept of ordained prophets functioning in the church. An official position paper approved by the US AoG in 2001 states that "the New Testament does not make provision for establishing the prophet in a hierarchiacal governing structure of the church." Whilst no one in the AoG is recognised by the title 'apostle' or 'prophet' the paper acknowledges that "many within the church exercise the ministry function of apostles and prophets." The fundamental reason for the AoG's non-acceptance of present-day apostles and prophets is made clear in a subsequent paragraph: "we look with grave concern on those who do not believe in congregational church government." The same document displays a hint of xenophobia in recommending that AoG churches use only AoG ministers to "lead, minister or pastor." General Presbytery of the AoG [USA] Official Position Paper, "Apostles and Prophets" (2001): 12-13. AoG in Australasia has a more relaxed approach to inter-denominational ministry. The perspective of the British AoG is clear in William K. Kay, Prophecy (Nottingham; Lifestream
} 
The governmental role relates to discovering the plan of God, delivered in terms of both general instruction and the identification of personnel.

It is in the realm of appointment of ministers that the prophetic element of divine government becomes most acute. The appointment of pastors to a congregation generally came via prophetic instruction and not from expressions of interest. The ordained prophetic channels would ordinarily nominate a man who was to be called; however, apostles, upon receiving a direct revelation from God, possessed authority to ordain an individual to any office. ${ }^{32}$ The "spoken word" also settled matters of doctrinal ambiguity, brought instruction on practical points and, on occasion, laid down the parameters for administrative issues. These further examples of the divine government model in operation demonstrate the willingness of the Apostolic Church to find in prophecy the solutions to issues which the governing bodies of other denominations may have settled by consensus debate. An interesting example of the use of the prophetic to illuminate doctrine is with the topic of prophecy itself: prophecies which address the function, origin and status of prophecy were used to clarify the doctrine as the following examples show. Prophecy given in 1934 at Hereford indicated that prophetic utterances belong to the church and that the apostles are responsible for the interpretation and outworking of governmental prophecies. A prophecy from Glasgow in 1923 declared that "when the word of God comes from the prophet there are no thoughts to come from the mind. It is not from the mind, I say, but direct from the inward parts." In 1928 prophecy from Glasgow asserted, "I declare the prophet himself, the vessel himself is not

Publications, 1991), 37, where he affirms that prophets are "intended to provide information ... rather than church government."

It would seem that the house church movement is more of a theological ally to the Apostolic Church with respect to apostles and prophets. UK house church movement leader Terry Virgo, Restoration in the Church (Eastbourne: Kingsway, 1985), 109; 114, endorses the notion of present-day prophets. See also Andrew Walker, Restoring the Kingdom (London: Hodder \& Stoughton, 1985), 148ff.

${ }^{32}$ Principles and Practices, 221. 
infallible; but that which I, the Lord, have given is infallible." ${ }^{33}$ Obviously the nature of prophecy was not in question or it could not have been used to bring insight concerning the doctrine of prophetic revelation.

Prophecy was the tool to evaluate at least one prophecy-related practice: "inquiring of the Lord" with regard to healing. Evidently, prophets were being asked to ascertain the outcome for a healing request put to the Lord. The prophetical response to this process clearly conveyed Divine displeasure saying "I will not endorse inquiring regarding the sick at any time." ${ }^{34}$ The question naturally arises as to whether the prophets had hitherto accurately predicted health outcomes and if so, by what power were they operating given the inability of the Lord to commend the practice.

Perhaps the single biggest feature that demonstrates the importance of prophecy to the Apostolic Church are the conditions placed on its use. The gift of prophecy was only to be exercised in the church under the supervision of the local presbytery; it was not to be privately used in homes unless "an elder or higher officer" was present and the occasion was a recognised church meeting. The following is the excerpt from a 1929 prophecy used to substantiate this instruction:

So in the realm of Prophets, I say whether by My Spirit, or by My Gifts, or by the Office, if I will speak, My Word is the same; but there is teaching and governmental office in the function of the Apostleship that must be displayed in the realm of Prophecy, so that the Church may realise that they are not governed and controlled to do all kinds of things by the Spirit of Prophecy and by those that have the Gifts, in the Assemblies everywhere, and at any time. For if this is to be the case there is no purpose to the function of the Office of the Prophet as a governmental Gift according to the perfection of My Will. ${ }^{35}$

The handling of the prophetic word was the purview of the apostle who had the responsibility to elaborate and act on received revelation. It was the responsibility of the congregation in turn to submit to the authority of the

${ }^{33}$ Principles and Practices, 224-225. 
apostles. The local minister and his presbytery were expected to elicit the compliance of the congregation with respect to resulting decisions. There was no hint of democracy in the government of the church.

\section{Shifts in the Practice of Prophecy}

Williams' view of prophecy shaped prophetic practice in the early days of the movement. It is noteworthy that the primary channel of prophetic utterance for the first years was his brother W. Jones Williams. Surely this relational proximity affected both the flow of doctrinal thought from the apostle, and prophetic revelation from the prophet.

Williams makes clear the preeminence of prophecy in the movement when he writes: "If we are called as an Apostolic Church to witness for some thing above another, we witness to the unassailable truth that we are a standing Body that is an evidence of the existence and value of the prophetic ministry." ${ }^{36}$ This stance is underscored by the fact that, before the advent of the tape-recorder, prophecies were taken down in shorthand and transcribed. ${ }^{37}$ Much attention was paid to the outworking of a prophecy, either in terms of awaiting its fulfilment or acting on the instruction contained therein.

Prophecy guided the church at every turn. Illustrative of the practical detail revealed in prophecies is the instruction, in 1917, to build a temple at Penygroes. A building fund was established but a later word directed that the fund should be distributed to Apostolic congregations struggling to provide a public meeting place. At the close of the 1932 Penygroes International Convention W. Jones Williams prophesied a challenge to his brother and the congregation: "My people, have you faith to believe that you will be sitting in a

\footnotetext{
${ }^{34}$ Principles and Practices, 226-227.

${ }^{35}$ Principles and Practices, 206-207.

${ }^{36}$ Williams, Prophetical Ministry, 100.

${ }^{37}$ Worsfold, Origins, 37.
} 
temple of your own when you gather on the Mount next time?" At that time the building fund was empty but at the next convention the thousand seat auditorium was opened and completely paid for. ${ }^{38}$

The Apostolic Church practice of using prophecy to nominate local officers was a unique feature, and one that drew criticism from other pentecostal groups. This system was slowly abandoned in the decade following 1940, the task of making appointments falling instead to the apostles. Currently, appointments are initiated by the local minister in consultation with a supervisor. This begs the question as to why the practice fell into disuse; in a later section we will examine some of the reasons.

Apostolic Church historian James Worsfold observes that "since the 1950s the function of the prophet in the Apostolic Church around the world has, in many instances, settled for a manifestation of the gift of prophecy." $\mathrm{He}$ continues, estimating that since that time an ordained prophet would have needed to "receive a charism of exceptional spiritual boldness" to even equal the status of ministry evident during the first two decades of the movement. ${ }^{39}$ In this he must be referring to the prophecies in the first years of the movement which addressed world events, for example, the Great War.

The Apostolic Church in New Zealand mirrored the mother church in Great Britain in terms of theology and praxis until well after autonomy was achieved. Gradually, as executive roles began to be filled by indigenous leadership, the antipodean counterpart took on its own identity, developing characteristics that reflected the local activity. The contemporary Apostolic Church of New Zealand has moved a significant distance from the position of relying on the prophetic for decision-making. For example, an occasional feature of the annual national

\footnotetext{
${ }^{38}$ Worsfold, Origins, 185. Here Worsfold also records that W. Jones Williams prophesied concerning the need for the Penygroes elders to purchase land as a cemetery so as to avoid going from place to place to bury their relatives.

39 Worsfold, Origins, 184.
} 
convention in Wellington in the 1930s and 1940s was the practice of allowing the prophet to nominate the speaker for a particular service from among the leaders assembled for pre-service prayer. This method was adopted from the Apostolic pioneers in Wales who relied on the Holy Spirit extensively and thrived on responding to the unexpected. ${ }^{40}$ In an earlier section examining the nature of prophecy we discussed the previously held concept of prophecy as an infallible gift. Current understanding in the Apostolic Church is markedly different and correspondingly the language has changed: prophecy is seen as participation of the human mind with the Divine. Given the opinion that the quality of prophecy declined following the first twenty years of the movement, the mix of divine and human in revelation is reckoned to be weighted towards the human component.

With the downgrading of the prophetic, so too has the function of the apostle changed. Once charged with the responsibility to fulfil in the congregations the word of the Lord through the prophet, the apostle has become little more than a superintendent minister. The task of expounding the prophecy and activating the outworking of it has given way to a simple endorsement and a wait-and-see approach. That is, the role of prophecy is more confirmatory rather than directional.

In the early 1940s the Apostolic Church in Great Britain reassessed the scope of the prophets' function on account of perceived over-involvement in administrative matters. For instance, it was thought that reliance on prophetic nomination to identify supporting ministries in a congregation unnecessary, the function more properly exercised by an apostle. The function of a prophet also became a matter of controversy in Australia, and the president at the time requested the council in Britain to resolve the issue. In New Zealand the issue

\footnotetext{
${ }^{40}$ Worsfold, Origins, 285.
} 
did not reach the same magnitude but it nonetheless became a point of discussion and the deliberations of the British were of interest. Given that prophetic operation was a hallmark of the Apostolic Church, the ramifications of any resolution altering the established order had the potential to affect the very heart of the movement. These considerations must surely have played a part in the action of the British council in sending members Hugh Dawson and William Rowe to Australia and New Zealand in 1942 to communicate the decision of the mother church in person. The message brought by Dawson and Rowe reinforced the primacy of the apostolic office over the prophetic which, while biblical, had the effect of reining in the prophet. A corollary of this position is that the apostles were to nominate individuals to office rather than simply ratifying prophetic revelation. While the intention was to endorse governmental prophecy, the opposite was achieved and the profile of the prophet in the church was never regained. ${ }^{41}$

Wilfred Frater, a prophet from 1958 until his retirement in 1981, represents one of the New Zealand prophets who refused to be restrained, exercising his full authority at a time when spoken revelation had ceased to carry the weight it once did. In 1979 he prophesied that James Worsfold was to be the next president of the movement. Usually apostles expected to make that decision themselves. He recalled that "electricity" surrounded the utterance; Worsfold was at the time in charge of the Auckland assembly, a pastorate the council forced him to take at least two years earlier in a decision that was passed without prophetic input. An earlier example of Frater's prophetic authority in action was his challenge to the council, in prophecy, to repent for repressing prophetic operation. Under the chairmanship of the president at the time, Marcus Goulton, the apostles repented with the result that the Holy Spirit fell

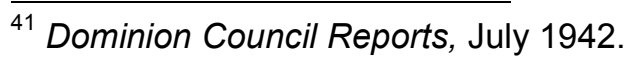


and many prophecies flowed from apostle and prophet alike. The prophetic voice could also be active in highlighting untoward behaviour on an individual level: in 1980 Frater prophesied that Apostolic Church minister in Rotorua, David Te Whare, was in an ongoing sexual liaison with a woman. While the activity of the bachelor Te Whare was known to his local elders, most of the national council were unaware of events until the prophetic revelation came. ${ }^{42}$

Two of the eight points which comprise the vision statement of the New Zealand Apostolic Church have reference to prophetic activity: (i) "encouraging new apostolic and prophetic initiatives" and (ii) "equipping and empowering ascension ministries." 43 The phrase "ascension ministries" refers to those church offices bestowed by the ascended Christ and listed in Ephesians 4:11 viz. apostles, prophets, pastors, teachers and evangelists. It is clear, therefore, that the vision of the Apostolic Church includes equipping and empowering prophets. What is not immediately apparent, however, is the scope and form of the desired initiatives described as "apostolic and prophetic." The terms "apostolic" and "prophetic" have current connotations that differ from the usage of earlier generations of the Apostolic Church. C. Peter Wagner, in his book Churchquake, points to the priority of evangelism resulting in the establishment and overseeing of new churches as characterising the function of an apostle. ${ }^{44}$ While this nuance was not missing from the understanding of Apostolic Church founders, the main thrust of meaning was restorationist, that is, recognising the offices present in the apostolic age. In the contemporary setting, when a

\footnotetext{
${ }_{42}$ Wilfred Frater, phone interview with Luke Worsfold, 13 October 2002.

${ }^{43}$ The eight points which appear in the web-site www.apo.org. are as follows:

- Fulfilling the Great Commission through the release of apostles and their networks

- Encouraging new apostolic and prophetic initiatives

- Aggressively promoting evangelism with global vision

- Equipping and empowering ascension ministries

- Developing Godly leaders with a prosperous soul

- Challenging leaders to humble themselves in prayer and fasting

- Planting Christ-centered churches that multiply

- Developing strong local churches that are interconnected for greater effectiveness
} 
movement or an individual's ministry is described as "prophetic" it does not necessarily refer to the existence of prophetic utterance. Instead, the meaning is broader, describing the action of revelation as occurring with a less welldefined modality.

Currently, prophecy in the Apostolic Church NZ does not enjoy the preeminence it had previously. According to Manu Pohio, who in 2002 was the longest serving apostle in the NZ movement, significant periods of time have elapsed without much prophetic utterance at all. ${ }^{45}$ At the level of national governance, that is, in the National Leadership Team (NLT) who have overall responsibility for the movement in New Zealand, the decisions reached have been via a more consultative process rather than guidance by prophetic word (as was previously the norm). Prophetic utterances are subject to a greater measure of assessment, or being "weighed," as compared to New Zealand's earlier practice where the spoken word was accepted much more uncritically, after the manner of the church in Great Britain. This reflects the development of theology regarding the nature of prophecy. No longer is language of the divine mind possessing human tongues used: revelation is acknowledged as divine in origin but influenced by the human mind which formulates the words.

The role of the apostle in the realm of prophecy is to weigh, interpret and execute the revelation that is brought. This is the built-in safety feature ensuring that prophecy is not presented in a discernment vacuum but is evaluated for the benefit of the hearers. Objectivity is lost if the prophet attempts to initiate action himself and revelation is diminished if apostles speak prophetically. Recognising the distinction that exists in the roles of apostle and prophet releases the synergy inherent in the operation of the twin ministries. The responsibility for implementing prophecy lay with the apostles. While this

${ }^{44}$ C. Peter Wagner, Churchquake, (Ventura, CA.: Regal Books, 1999), 107. 
was a great safety for the prophets it was also an area requiring much grace and surrender to the Lord in that any prophecy spoken in council meetings would be weighed by the apostles then and there in the prophet's presence. The prophecy would usually be categorised in one of three ways: suitable for immediate action; requiring more light; outright rejection. It was unusual for a prophecy to receive the third classification. ${ }^{46}$

A unique feature of the Apostolic Church was the apostle-prophet ministry which brought into focus the tandem operations of apostle and prophet through the itinerant ministry of a regional or national leader and an ordained prophet. This was employed with good effect by James Worsfold and Hone Maxwell during the former's presidency in the early 1980s and functioned by way of Maxwell, the movement's most senior ordained prophet at the time, focussing on a specific area in which he felt the apostle, Worsfold, required revelation. This could be: a problem in the church; question of future direction; or identification of church officers for ordination. Maxwell would feel "activated" by something Worsfold said, being stimulated to seek the Lord for clarification or confirmation on the issue. In the calling of an individual to ordination, for example, Worsfold would indicate that he had someone in mind which prompted Maxwell to seek God for the person's name. In approximately $80 \%$ of cases the name revealed to Maxwell was unknown to him. The whole process served as solid confirmation that the apostle was on the right track. An interesting case in this regard is the call of Donald Lake, currently the most senior of the national prophets. He was, at the time of his call to ordination as a prophet, speaking prophetically at a level beyond what would be expected for the gift of prophecy; consequently, there was reluctance to accept his words. Maxwell prophesied at a national council meeting that "my servant Lake" should be set apart as a

${ }^{45}$ Manu Pohio, phone interview with Luke Worsfold, 7 October 2002. 
prophet. Maxwell had not at the time heard of this young man in the Dunedin assembly of the Apostolic Church. ${ }^{47}$

In terms of authenticity it is the gold standard for a prophet to speak without full recognition or understanding of what he is saying. If the contact between an apostle and a prophet is too close then it is difficult for the prophet to hear outside of those conversations and tune into God's message. Often the apostles felt threatened by the prophets, reacting to the impression that the prophets were telling them what to do. A correction brought by the prophet ran the risk of being taken personally by an apostle, or apostles, and so defensive attitudes would arise. The apostles' fear of diminished control fuelled a backlash to the apostle-prophet ministry demonstrated by Worsfold and Maxwell: the accuracy of prophecy and the high correlation between apostolic statement and prophetic direction went beyond nervousness to outright suspicion of conniving, with the result that the roving ministry of apostle and prophet was undermined. So too was the ability of the prophet to speak directly, and with strength, to issues at the national level challenged. ${ }^{48}$

Worsfold was the last president of the movement, subsequent leaders being identified as "superintendent" and then "national leader." John Douglas succeeded Worsfold as superintendent in August 1986 and brought an influence that was far less pentecostal. His main interest was in education and he undertook the dual roles of superintendent and principal of the national training school, Te Nikua, which he developed along lines that, to a large degree, ignored pentecostal teaching. In 1988 Maxwell prophesied at the national council meeting that Douglas was not to be re-elected superintendent and that Te Nikau should be closed or the movement would face bankruptcy. Phillip Underwood, who replaced Douglas as principal in 1989, became the

${ }^{46}$ Frater, interview, 13 October 2002. 
national superintendent in 1995 which signaled further changes in the governmental function of prophecy. Underwood did not embark on an apostleprophet ministry throughout the movement and the tone of the council meetings moved more toward an emphasis on debate rather than revelation. ${ }^{49}$ As national leader, Phil Underwood would challenge the prophet to "explain himself" following an utterance with which he could not find an appropriate level of agreement. In contradistinction to the earlier practice of Worsfold to request further guidance from the Lord through the prophet on a point needing clarification, Underwood directed his question to the prophet who was then expected to answer out of his own natural understanding. ${ }^{50}$

Another reason for the abandoning of apostle-prophet ministry was that the council were looking at other movements, hoping to find practices they could adopt and successfully apply; movements such as the Assemblies of God that did not recognise all the five-fold ascension ministries. The drive for church growth motivated younger members of the council to rely on natural talent rather than the spiritual exercises of prayer and waiting on God for prophetic revelation. As a result of the focus on expansion, some congregations grew but at the expense of depth of spirituality. The contention of the earlier breed of Apostolic leaders was that if the movement stayed in the realm of the Spirit, then growth would come as a result. Since 1990 there has been a marked emphasis on church growth and this has seen some apostles operate independently of the prophet insofar as the direction for the movement had been set down: apostles could move without prophetic input in outworking what had become the established strategy of expansion through evangelism. ${ }^{51}$ The result is that the voice of the prophet has not been heard with the same

\footnotetext{
${ }^{47}$ Hone Maxwell, phone interview with Luke Worsfold, 12 October 2002.

${ }^{48}$ Don Lake, phone interview with Luke Worsfold, 14 November 2002.

${ }^{49}$ Maxwell, interview, 12 October 2002.

${ }^{50}$ Lake, interview, 14 November 2002.
} 
frequency since. Consequent to a de-emphasis on the prophetic came the curtailment, even disappearance, of the "apostle and prophet ministry."

The sudden departure in 1997 of the national superintendent, Phil Underwood, to a congregation in Pennsylvania left a vacuum felt keenly by the new leader Nick Klinkenberg which prompted him to carry out his "air tour." This comprised a series of visits by Klinkenberg and a prophet to all geographic regions to minister encouragement and guidance to the pastors of that area. ${ }^{52}$ Klinkenberg's air tour heralded a definite attempt to recapture the ethos of the Apostolic Church by appealing to divine guidance via the prophetic voice. However, the initiative, while demonstrating the interest of the national leader in the local church, produced equivocal results: there had not previously been a close working relationship between Klinkenberg and the various prophets and expectations of ministry were not always clear. This expression of apostleprophet ministry came early in his superintendency and was not attempted again during his tenure, however, Klinkenberg's effort did break the hiatus of apostle and prophet ministry on a national scale that had existed since the 1980s excursions by the duo of President James Worsfold and ordained prophet Hone Maxwell. There has not been any exercise of this nature from the current leader, Bruce Monk. ${ }^{53}$

The dissolution of the regional supervisory system and replacement with "movement supervisors," ${ }^{54}$ where relational rather than geographical boundaries

\footnotetext{
${ }^{51}$ Pohio, interview, 7 October 2002.

52 The four prophets who accompanied Klinkenberg on the various legs of the tour were: Don Lake, Graeme Lee, Jack Guerin, Andrew Vossen.

${ }^{53}$ A logistical difficulty arises should Monk want to pursue this type of ministry in that he is based in London as the pastor of a new plant called "The Equipper's Church."

${ }^{54}$ The supervisory structure for any local church pastor consisted of a regional superintendent minister who reported to the national council, itself comprised of all the apostles and prophets. A subset of this body, the executive council, operated as the working arm of the national council. The superintendent would oversee the work of a pastor in a general sense and perform such visible duties as induction of pastors, commissioning of elders and other leaders. In the 1990s the regional system was replaced with a relational network whereby pastors were given the freedom to choose whom they would submit to as a supervisor. Movement supervisors are
} 
dictate associations, has effectively removed opportunity for a supervisor and prophet to minister to an assembly of regional pastors. Under the current system, if a movement supervisor was in fact an apostle and wished to minister with a prophet to those under his oversight, he would have to visit each congregation individually. The replacement of regional supervisors with networks headed by "movement supervisors" was not a notion that was birthed in prophecy; rather, it was an idea promulgated by Monk and reluctantly implemented by Klinkenberg while national leader. ${ }^{55}$

A current problem with the operation of apostolic and prophetic office in the government of the church is the blurring of roles: prophets are entering into discussion and apostles are prophesying. According to Maxwell, prophets who engage in debate weaken the revelation they bring. Similarly, it might be stated that apostles lose their objectivity when they prophesy. In the period surrounding the mid-1980s the apostle-prophet ministry was high-functioning in council meetings. Maxwell describes the action of the prophet in such an environment as an active listener to proceedings who brought revelation when lack of clarity blocked the decision-making process. If the prophet was silent when the apostle's discussions stalled he may find himself challenged by the chairman to speak. Conversely, if the prophet brought a word that was obscure the chairman was known to demand the prophet to speak again to clarify the first utterance. Originally prophecy featured highly in governmental decisions by the movement's leadership, a practice inherited from the church in Great Britain and the expatriates who served in New Zealand. The National Leadership Team now conducts its business with a greater reliance on discussion amongst the apostles with prophecy serving as a contributing element. Similarly, response to prophecy at national government level is 
weighted toward consensus with the recourse to voting should the need arise. A notable exception to this mode of operation is the prophetic revelation which identified, by name, the current leader of the NLT, Bruce Monk. ${ }^{56}$ It should not be assumed that the earlier councils in the Apostolic Church, either in New Zealand or Great Britain, handled prophecy without apostolic judgement, but the spoken word undoubtedly influenced decision-making more frequently. The topics of prophecy are different as well: matters of doctrine are not addressed, details of undertakings are not prescribed, instead, the general direction of the movement is affirmed or some developing focus may be endorsed. Interestingly, affirmation figures more highly than warnings or restraints.

In the local church, prophecy, like any spiritual expression, depends largely on the profile afforded it by the pastor. Manu Pohio, senior pastor of the 300 member Apostolic Church in Rotorua prefers to see the "prophetic recognised" and gives it high priority. The Sunday service he describes as "celebrative" and therefore not conducive to prophetic expression. However, in mid-week gatherings the atmosphere is suitable and any message brought is reinforced with an exposition. This profile of prophecy he does not think is representative of the Apostolic Church nationwide, but attributes his accent on prophetic revelation to having grown up in the movement. ${ }^{57}$

NLT member Craig Clements finds that in the 75 member Apostolic Church he pastors in Pukekohe, prophecy is regular feature in the Sunday services with up to three contributions on any occasion. The prophecies are delivered, grammatically, in the first person, sometimes highlight a scripture, may be directive in a general sense and are usually spoken out with

\footnotetext{
location in the country.

${ }_{55}^{5}$ Lake, phone interview, 14 November 2002.

56 The nomination of Bruce Monk, leader of the NLT since 2001, was brought by national prophet Tony Faitala. Information supplied by NLT member Craig Clements, phone interview with Luke Worsfold, 8 October 2002.

${ }^{57}$ Pohio, interview, 7 October 2002.
} 
confidence. ${ }^{58}$ A short exposition would ordinarily follow and opportunity given for the congregation to respond, even if it is only a prayer offered by the leader of the meeting. He also does not think his church is representative of the movement nationwide $;^{59}$ perhaps his own experience with the gift of prophecy goes some way toward explaining the abundance of prophetic revelation in his congregation.

It is worth noting at this point that a comparison of the two congregations mentioned above shows that although both pastors are keen for prophetic revelation, it is only in the smaller gathering that prophecy operates in the traditional way. Several factors may combine to create this situation. The first is the different psychological and spiritual make-up of the attendees at large and small pentecostal services. Those attracted to the smaller meeting may enjoy the intimacy generated in the smaller crowd and may also feel they have a contribution to make. The limited number of people participating facilitates the involvement of those so inclined. Conversely, sizable pentecostal congregations tend to have developed a polished presentation which militates against spontaneous contribution. Those that attend are drawn by the performance and enjoy being part of something obviously successful. Add to this the risk factor of unknown or unwell contributors and it becomes apparent that prophecy fails to be a hallmark of the public gathering in such a setting.

The appointment of an apostle or prophet was formerly by prophetic nomination and then ratification by the apostles. This was the standard procedure up until the 1980s. Currently, prophets and other apostles are nominated by apostles and the appointment made via consensus with or

\footnotetext{
58 This is in contradistinction to prophecies which focus on acknowledging the human component and become tentative in delivery prefacing a message with phrases like, "I feel the Lord is saying" or "I think maybe the Lord wants to say." The Charismatic Renewal popularised this form of expression which, while displaying humility on behalf of the speaker, can remove potency from the utterance.

${ }^{59}$ Clements, interview, 8 October 2002.
} 
without the voice of prophecy having any input. The analysis of this departure is best handled in the next chapter, but suffice to say it can mean one of two things: either, prophecy is being relegated to its rightful place and the revelation from apostles recognised as sufficient or, prophecy is still of a high order but its deserved status is being obscured or ignored.

The value of prophetic guidance in national government is evidenced in the above-referenced selection of the current Apostolic Church leader, Bruce Monk. The various options under consideration at the time were committeebased or individual leadership by either Bruce Monk, Manu Pohio or continuation by the incumbent Nick Klinkenberg. The support for the three candidates among the 25-member council was evenly distributed so no clear resolution emerged from the deliberations. When the prophets, who were literally outside the discussion, returned to the meeting room, numerous prophecies came which were cumulative in effect. Initially, the message pointed to the need for change in the movement; then there was the indication that a time of transition lay ahead for the church in order to effect this change. This inferred that the term of office for the new leader would be for a short time only and that a persuasive personality was necessary. Upon this groundwork came the prophecy via Tony Faitala that Bruce Monk should be the next national leader. Such a specific word early in the proceedings would have fallen on unsympathetic ears, but the prophecies brought the revelation progressively and was thus able to be accepted. ${ }^{60}$

In the realm of the prophetic the purview of an apostle is to judge a prophecy, deciding if any part(s) should be discarded as not inspired, enacting those elements that require immediate attention and holding in abeyance what belongs to the future. A cardinal rule is that apostles execute the proceedings

$\overline{{ }^{60} \text { Lake, interview, } 14 \text { November }} 2002$. 
of a prophecy; prophets do not initiate action on revelation. If less prophetic revelation is available, apostles must therefore rely on their own revelation which, while complementary, is different. Given that divine revelation is subjective at best, the objectivity inherent in the process of prophecy through one individual and assessment through another is lost. This leaves the apostle in the precarious position of receiving primarily internal revelation. The counsel of other apostles mitigates against this.

A specific feature of the pioneering days of the Apostolic Church in New Zealand was the evangelistic effect of prophecy on the non-Christian. While prophecy is in the first instance for the benefit of the believer, St Paul refers to the secrets of the heart being publicly disclosed with a consequent falling down before God, confession of $\sin$ and affirmation of His presence in the midst. Writing in 1986 as the President Emeritus, James Worsfold noted that "there is a decided absence of this sort of 'falling down' in churches where prophecy is heard." ${ }^{\prime 1}$ The situation remains the same in 2004 with the believer retaining the focus of prophecy. Of influence here is rise of the personal prophecy. The scriptural analysis of the practice will be dealt with in the following chapter but the effect of personal prophecy on the individual can be detrimental, creating a dependence on revelation at the expense of developing a personal relationship with God.

There are, of course, examples of the national leadership failing to follow prophetic guidance to the detriment of the movement overall. ${ }^{62}$ However, generally prophecy had always been highly regarded and consistently applied in

\footnotetext{
${ }^{61}$ Worsfold, "The Apostle Prophet Function," Apostolic News (August 1986): 2.

${ }^{62}$ During the presidency of Worsfold, prophetic instruction via Hone Maxwell indicated that the former was to return from the assembly in Thorndon to the central Wellington assembly, Charisma Chapel, which he had vacated against his will some years earlier. The prophetic guidance for Colin Goulton, the incumbent, was to go on a missionary journey with his brother Ron. The prophetic message warned that failure to follow the divine instruction would result in God not blessing the Wellington assembly. The prophecies were not acted upon, the congregation never regaining the influence it enjoyed in the city, and in 1999 the pastor, Mike
} 
the Apostolic Church and so, to the Assemblies of God movement in New Zealand, the Apostolic prophets were dictators - the Apostolic government perceived as entirely prophecy controlled. The operation of "divine government" within the Apostolic Church was a well-known feature and was at complete odds with the Assembly of God system which utilised the democratic vote. ${ }^{63}$ The prophets, however, felt their influence was severely attenuated. James Worsfold, functioning in his early years as a national prophet, remarked to Frater that "prophets will never influence the movement until they are apostles." The framework of prophetic operation became one of restraint; Apostolic Church prophets perceived their counterparts outside the movement as having greater freedom. For example David Schock, from Los Angeles, was afforded much freedom in Apostolic services and pastors' meetings while in New Zealand during 1968, a privilege not available to a local prophet. ${ }^{64}$

It is clear that the concept of prophecy as a pure word from God with attendant force of effect faded from the time of the Williams brothers to the period under review. Apostles could be arbitrary in their handling of prophecy, especially if it cut across them or their interests. Frater recalls one occasion, while travelling with a president, when he brought a prophecy warning an evangelist in Nelson who wanted to give up his ministry. The president told the evangelist, who was his friend, "not to worry" about the prophecy. Frater's recollection of travelling with several presidents around various congregations was that often the apostle was unable to offer specific guidance relevant to a

Witenberg, left the movement taking some of the congregation with him. An attempt to restart the city centre church was made in 2000 and is presently continuing.

${ }^{63}$ With the rise of the prophetic in the Assemblies of God and the use of the term "apostle" to describe some of its leaders, the question of a persisting Apostolic Church distinctive emerges. We have previously discussed the efforts of the New Zealand Assemblies of God and Apostolic churches to amalgamate, the stumbling block at the time being the recognition by the Apostolic Church of ordained apostles and prophets. The roadblock to an organic union is well on the way to being removed and the course taken by the Australian counterparts in forming an umbrella organisation, Australian Christian Churches, may well signal that a similar outcome in New Zealand is possible.

${ }^{64}$ Frater, interview, 10 January 2003. 
situation, instead conveying a generic message. The tenor of prophecy, even at governmental level, was usually one of encouragement: topics centred on attitudes and direction for the movement with only a small percentage of revelation addressing specifics. In the period of the quadrennial shifts only a small number of nominations came via prophecy.

As we have seen, in the mid-1980s there was a shift in the mode of leadership from a charismatic to a management style. In so doing the government of the church relied less on prophecy and more on discussion. The consequent devaluing of prophecy affected the quality of utterance where, in the estimation of the movement's most senior prophet, Donald Lake, the level of divine inspiration fell from $80 \%$ to $40 \%$ for any given prophecy ${ }^{65}$. Prophets tend to rise to the level of expectation placed on them: if there is no anticipation on the part of the apostle that the utterance will be highly inspired then it is unlikely that the prophet will produce anything of substance. ${ }^{66}$ The infiltration of bureaucratic systems generated the notion that prophets were superfluous for gaining an understanding of God's plan hence the prophets' role was reduced to endorsing or encouraging the decisions of the apostles.

\section{The Process of Prophecy}

Among the ordained prophets there was no official hierarchy, however, seniority was established on the basis of experience. ${ }^{67}$ A prophet could rate his level of anointing by the frequency with which he was required to attend council meetings or accompany the president on nation-wide travel. The protocol for prophetic input in council meetings was for prophets to "wait on the Lord" for

\footnotetext{
${ }^{65}$ Recall that there was a general understanding within the movement that prophecy was a divine-human blend; a prophet of Lake's standing would be considered qualified to make such judgements.

66 Lake, interview, 14 November 2002.

67 The senior prophets from 1950 onwards were: James Worsfold, Lewis Derry, Wilfred Frater, Hone Maxwell, Don Lake.
} 
revelation; they were not to take part in the discussion. Prophecy would ordinarily be given during devotional times at the start of the day's session, the rationale being that it was difficult for a prophet to bring forth a prophecy during a debate. Frater recalls, in cases of little progress being made in the apostles' discussion, requesting a break in the proceedings for prayer, during which time he would bring a prophecy.

Up until the 1980s a national convention for the movement was held in Wellington every Easter and the expectation for prophetic ministry was high. The unspoken protocol was that senior prophets would speak before the more junior. There did not appear to be any guidelines regarding the number of utterances because the junior prophets would often enthusiastically reiterate the context of a prophecy without adding any new revelation. In this public environment the content of prophecies was restricted to edification, exhortation and comfort of the movement as a whole. ${ }^{68}$

Prophets have communication from God that, while individualised, shares some common features. For Frater there was an associated sense of command. Revelation would grow, oftentimes via the initial stimulation of Bible reading, until the full text of the utterance would be known. Prophets often speak of "carrying" a word, even "wrestling" with it for a period of time before discharging it. However, it was not always the case that the entire content of a prophecy was available to the prophet prior to delivery. ${ }^{69}$ In fact, Frater's first

\footnotetext{
${ }^{68}$ Frater, interview, 13 October 2002.

69 The literature of the charismatic movement records various forms in which the message is received. An entire message my be received prior to delivery (Yocum, Prophecy, 100) or perhaps only the first few words, the remainder coming to mind as the person speaks. Margaret Paloma, The Charismatic Movement (Boston: Twayne, 1982), 79. See also, Michael Harper, Walk in the Spirit (London: Hodder \& Stoughton, 1968), 76. As opposed to receiving the text of a message, the general sense only may be known to the speaker: it is then up to that person to "apply the right words" to deliver the message. Yocum, Prophecy, 77. Others may hear an internal voice which may be so realistic as to give the hearer the sensation of being addressed by an audible voice. This voice may only reveal a simple word of phrase. Huggett, Listening, 105. Similar to this is the celebrated example given by John Wimber in the book co-written with Kevin Springer, Power Evangelism: Signs and Wonders Today (London: Hodder \& Stoughton, 1985), 44-46. In this situation Wimber "saw" the solitary word 'adultery' across a stranger's
} 
prophecy was more of an instantaneous dispatch whereby he, at the close of a prayer-meeting, declared: “Don't hurry away! If you wait I'll pour you out a mighty blessing." In respect of Frater's future confidence it was fortuitous that the leader of the meeting responded positively, encouraging those gathered to wait. The result was that after a period of about five minutes the Holy Spirit fell and there were scenes of great laughter and joy.

Frater recalls one occasion, in his early years of prophesying, where the content of his prophecy was against his own thinking on the subject. This phenomenon suggests the "divine conduit" mechanism for prophecy which was popular with the Apostolic Church fathers. However, it is worth reinforcing the points that this event was in the formative years of his prophetic experience, and that the concept of revelation growing over time forms Frater's description of the process.

Current understanding in the Apostolic Church is that prophecy is divinely inspired but passes through the theological filters of the speaker. The delivery makes it apparent that there is another dimension operating in this spiritual gift: most often the message is given with a verbal intensity beyond that of normal speech, similar to the preaching style of many evangelicals and pentecostals. It is not unknown for otherwise halting and severely impeded speakers to operate with great fluency when prophesying. ${ }^{70}$ The prophetic function can be extraordinary when a prophet is operating with a high degree of inspiration; here the words have a measure of continuing life, although without approaching the level of inspiration found in Scripture. When the divine element is noticeably

face. Wimber explains that he saw the word in his "mind's eye." Other imagery may come in the form of dreams or visions which require interpretation, the image not normally standing alone. S. Grossman, Stewards of God's Grace (Exeter: Paternoster Press, 1981), 103.

70 James Worsfold, as a young man, had a severe stutter, being unable to complete more than a few words without faltering but could prophesy at length without any hint of an impediment. C. M. Worsfold to Luke Worsfold.

Hone Maxwell has never had clarity of diction but could prophesy smoothly. Personal knowledge. 
absent, the word is more of human origin and the exercise is ordinary. Whatever the case, the Holy Spirit empowers the prophet to speak forth words selected out of his own vocabulary, the action reflecting the divine-human interplay.

Of pivotal importance to the study of the prophetic process is an appreciation of the role prophecy has in a particular sphere of hearing. At the governmental level, prophecy is a distinguishing feature of the movement, and locally it functions as the word of the Lord directly to the community of believers. It is not seen as an optional extra, rather, a facility which underpins the very existence of the denomination. The significance of prophecy to a congregation, and the movement as a whole, fashions the process of prophesying. A prophecy does not come to the congregation "out of the blue" on a topic unrelated to any activity of the church. Instead, the prophecy speaks to current issues, in most cases bringing revelation or endorsement of chosen courses of action, and is therefore received and treated as valuable divine input. In most situations the prophet is not unaware of the church's endeavours and so contributes as an insider. This is an important aspect of the formulation of the prophecy: the speaker is active on behalf of the congregation he belongs to, initially waiting on the Lord for revelation then delivering the message to his fellow worshippers. The value placed by the movement on prophecy means that evaluation of a public utterance is not generally subject to rigorous assessment. Prophecies that exhibit a low level of inspiration are often ignored by the leader, with only the very forthright making corrective comments. Equally, prophecies which do demonstrate an acceptable level of inspiration are often not commented on, indicating that there exists no standard protocol on handling the prophetic word. Given that prophecy is a valued expression in pentecostal circles, the prophet goes through the process of receiving his 
message with positive anticipation. Unless it is a difficult topic or he has been subject to prior censure by the leadership, the prophet does not have to battle any theological resistance to the concept of God speaking directly via a human channel. However, there may be some trepidation felt in the sense of a desire to bring an accurate message and not one overly influenced by personal reflection.

The process operates with a different dynamic at the governmental level. Not only is the prophet expected to speak but his utterance is subject to immediate scrutiny by the apostles. Maxwell recalls that between 1979—1986 the president during that period, James Worsfold, was known to demand further prophecy from a prophet if the initial utterance required some clarification. This was a challenging test which at times proved the human element of prophecy to be operating at too high a level. ${ }^{71}$ Similarly, if the prophets were silent, Worsfold would bring a reminder concerning the ineffectiveness of a dumb prophet and thus prod them into action to bring the required revelation to the deliberations of the council.

Prophecy, while extemporaneous, is not without preparation. It is impromptu in that it is unrehearsed, yet there will have been a previous deposit in the spirit of the prophet which is later released in the moment of utterance. The standard form of preparation is time alone with God in prayer and fasting, not necessarily to receive the content of a message but to be refined as a instrument of the Lord. The appropriate preparation was outlined by Frater in a brief publication on the topic of prophecy. He paints a word-picture of rain clouds, springs and the ground to demonstrate how an individual can be used by the Holy Spirit to prophesy. As the rain clouds gather and the springs start to

\footnotetext{
${ }^{71}$ Maxwell recounts an occasion when Graeme Lee prophesied in the council, "you have blood on your hands." Worsfold, as president, felt the statement to be inaccurate and said, "Lord, reveal to me through the same prophet what was meant." Lee sat silent totally unable to
} 
flow, the ground is therefore softened to receive the rain. For him there were three important factors:

i. The spring is prepared. That is, the person or vessel has "steeped himself in the Word, especially the prophets" and has spent time in "private praise and worship." The activity of waiting in God's presence can stimulate the insertion of words into the spirit of the prophet. After such preparation, the prophet should "forget everything and trust the Holy Spirit to recall it in times of fellowship."

ii. The atmosphere is prepared. This includes the "prophetic climate," which is not further identified, the timing of the Lord, the tuning of the Lord which is the context-specific signals, and participation by the prophet in praise and worship of the gathering.

iii. The ground is prepared. This is the corporate expression of praise and worship which prepares those gathered to receive. It progresses through stages of thanksgiving, praise and worship. Under this item Frater also notes that: 'Leaders are sometimes used to 'seed' the clouds. A touch of leadership in the right place can precipitate the operation of gifts." ${ }^{72}$

Depth of private devotion is one characteristic of a prophet: Riches of Grace carried an article which identified preaching as the result of study and meditation while "prophethood was not just the result of study and meditation . . . it is the product of a deep effective relationship in walking with the Lord." ${ }^{73}$

The second component which effects the completed prophetic event is appropriate environment. A prophecy is not brought in isolation either

respond, whereupon Worsfold pronounced Lee to have "no anointing." Maxwell, interview, 12 October 2002.

${ }^{72}$ Wilfred I. Frater, Prophecy (n.p., n.d.), 10.

The details of the analogy are not explicitly stated, but it would seem that as the prophet has previously spent time with God and the congregation enters into praise and worship together, God allows prophetic revelation to build (the rain cloud) until the prophet delivers the message (the rain).

${ }^{73}$ Allen Richards, "The Twin Ministry of Apostles \& Prophets," Riches 1, no. 8 (1985): 123. 
physically or contextually. To that end, an element of fellowship is requisite and the forum must be conducive to spiritual exercise: it would be as unexpected for an individual to prophesy to himself as it would be to receive prophetic revelation at a church soccer game.

In any gathering where prophecy may be exercised the leader's role is not only to evaluate the utterance but to make room for it in the first place. The leader may sense a spiritual intensity or, more specifically, that a message is imminent and encourage the gathering to "wait on the Lord" or "pause in His presence," so providing the cue for a prophecy to be given. In order to stimulate prophetic delivery an atmosphere of worship or prayer is preferred over, for example, preaching, where there is a greater engagement of the cognitive over the emotionally-oriented spiritual dimension. This is not to say that prophecy by-passes the cognitive realm and impacts the spirit only; rather, the content of a message is subordinate to the context. The transcript of a prophecy may appear banal, yet the effect may have been stupendous; often it is the reminder of a simple truth, brought in a timely manner, that profoundly touches the hearer. Similarly, prophecy may appear too general to be of any significance when analysed out of context because the specificity is effected in the minds of the hearers who find the appropriate meaning. Prophecies that have a wider audience are necessarily of a higher order and may address issues of importance to a whole denomination on a national or international scale.

\section{Summary}

Since the inception of the Apostolic Church there has been a shift in the understanding of prophecy: initially believed to be a pure communication from God it is currently thought to be more of a divine-human participation. In the 
realm of church government there arose an emphasis on debate as opposed to revelation so that prophecy became a medium for confirmation rather than direction. Government of the church is now by consensus within the National Leadership Team with prophecy serving as an adjunct. The roles of apostle and prophet have become blurred: prophets are entering into discussion and apostles are prophesying, which has the twin effects of devaluing revelation and removing objectivity.

The tendency, on the part of the apostles, to execute prophecy in an arbitrary fashion is a reflection of a decline in the level of prophetic inspiration relative to the first two decades of the movement. Consequent to the lowered expectation on the prophet there has been a commensurate drop in the level of prophecy produced. This relegation of the prophetic has affected the function of the apostle: originally focussed on the fulfilment of the word of the Lord, the apostle's function has become that of a superintendent minister.

In the public setting, exposition of prophecy is rarely seen; instead, a variety of responses are found ranging from endorsement to nothing at all. While some congregations report a high frequency of the prophetic in their services this is by no means representative of the movement nationwide, the dearth of prophecy in the congregations perhaps reflecting the profile that prophecy has in the government of the church. 


\section{CHAPTER FIVE CRITIQUE OF PROPHECY}

The picture of prophecy in the Old Testament is by no means uniform, ranging from the primitive Canaanite guilds to the sophisticated first and second Isaiah, the visionary Ezekiel to the pragmatic Amos and the true to the false. While both Abraham and Moses enjoy the designation "prophet,"1 it was Samuel who was chosen by God to establish the distinct office and function of the Israelite prophet. After Samuel began prophesying it is said that God did not let any of his words fall to the ground. ${ }^{2}$ It is from this time that the formulaic phrase "thus says the Lord God of Israel" appears, prophecy therefore being heard in the first person. Although prophecy was rare and visions infrequent at the time of Samuel's childhood, the prophetic guilds were flourishing and demonstrated a contagious element to their characteristic invasive oracular speech. That the prophecy of the guilds was contagious is demonstrated by the response of Saul who enters into a prophetic seizure with attendant bizarre behaviour. It would seem that Israel was not entirely comfortable with

\footnotetext{
${ }^{1}$ See for example Gen 20:7; Deut 34:10.

Two British scholars, A. Graeme Auld and Robert P. Carroll, have attacked the understanding that there were prophets in ancient Israel and Judah. Their argument is that OT prophetic figures were in fact poets and were thought of as prophets only in exilic times. This stance has been adequately countered by, amongst others, Hugh G. M. Williamson and Thomas W. Overholt. See Philip R. Davies, ed., The Prophets (Sheffield: Sheffield Academic Press, 1996) containing: A. Graeme Auld, "Prophets through the Looking Glass: Between Writings and Moses," 22-42; Robert P. Carroll, "Poets not Prophets: A Response to 'Prophets through the Looking Glass," 43-49; Hugh G. M. Williamson, "A Response to A. Graeme Auld," 50-56; Thomas W. Overholt, "Prophecy in History: The Social Reality of Intermediation," 61-84. In particular, Overholt appeals to the socio-historical context to authenticate the existence, activity and status of the prophet. Overholt has elsewhere described his model of the prophetic process as containing two essential features: three entities (a deity, an intermediary and an audience) and a system of interrelation comprising revelation, proclamation of a message, and feedback. Thomas Overholt, Channels of Prophecy: The Social Dynamics of Prophetic Activity (Minneapolis: Fortress Press, 1989), 17-25.
} 
contagious prophecy: Saul's presence among these ecstatic prophets giving rise to the question carrying the nuance of disapproval, "Is Saul also among the prophets?" The contagion evident in the guilds sustained the individual members, whereas the Israelite prophet stood alone, often before kings, speaking the judgement of God. The close relationship which existed between king and prophet is a type of the interdependence later exhibited in the New Testament offices of apostle and prophet.

While the content of the Israelite prophets' oracles was often received prior to delivery, after the manner of Ezekiel, there is sufficient record of invasive prophecy occurring for it to be considered a part of the usual practice. ${ }^{3}$ The situation of Saul's approach to Samuel to elicit the location of his lost donkeys presumes that the prophet was considered capable of obtaining divinelysourced information immediately. Under Samuel, divination via the ephod, which yielded only affirmative or negative answers to closed questions, gave way to enquiring of the Lord through the prophet. ${ }^{4}$

Prophecy is not peculiar to Israel and, as Blenkinsopp reminds us, the ancient Greeks gave oracles in either rational or trance states, the transmissions of both forms being described as "prophecy." It was the "prophet" who interpreted the ecstatic and unintelligible utterances of the priestesses of Zeus or Apollo. Blenkinsopp posits that the translators of the LXX avoided mantis and manteuomai (ecstatic person and ecstatic behaviour respectively) in favour of prophetes and propheteuein in order to emphasise the declarative nature of Israelite prophecy while downplaying any sense of mantic behaviour. ${ }^{5}$

The Hebrew Bible uses four words to describe those who prophesy:

\footnotetext{
${ }^{2}$ I Sam 3:19.

3 Consider for example: Num 11:25; I Sam 10:5-6, 10-11; I Kings 13:20; note that invasive prophecy can be either with or without an ecstatic element.

${ }^{4}$ Divination, under Mosaic law, was reserved for official enquiry and not for personal matters.

5 Joseph Blenkinsopp, A History of Prophecy in Israel (Louisville: Westminster John Knox

Press, 1996), 27.
} 
1. nābî' is the most frequent and is translated "prophet." Verbal forms which derive from the noun exist in two conjugations, the niphael equivalent to the passive, and the hithpael equivalent to the reflexive. While it is true that the niphael is used of wild behaviour devoid of any prophetic element it can also refer to rational prophetic speech. Similarly the niphael can be used of both communal ecstatic behaviour and of prophetic utterance. It is therefore apparent that no clear distinction exists between the two forms although, over time, the niphael became the usual form in describing prophetic speech. ${ }^{6}$

2. rō'eh, seer. Peterson states that this type of prophet is "something akin to a diviner." He explains that such an intermediary operates in a manner different to other prophets; the diviner has an audience which has sought direction from the deity. The seer's social interaction with the audience constitutes part of the prophet's behaviour the record of which properly forms a valid part of the prophetic literature. ${ }^{7}$

3. hōzeh, seer. This type of prophet is a visionary. The title "seer" is used of Amos, Isaiah and Micah and these books contain vision reports (hezyōnōt). Although the seer may have deliberately sought the Lord for revelation, the vision does not result from the request of an audience. ${ }^{8}$

4. 'îš hā 'ělōhîm, man of God. Most used of Elisha (27 times) and Elijah (5 times) the title describes men who demonstrate God's power rather than uttering words or recounting visions. Peterson explains that, like the priest, the "man of God" profiles the sacred amidst the profane but without performing any rituals characteristic of priests. ${ }^{9}$

\footnotetext{
${ }^{6}$ Blenkinsopp, Prophecy in Israel, 28.

See also the discussion of A. Graeme Auld, "Prophets through the Looking Glass," 29-33.

7 David L. Peterson, "Rethinking the Nature of Prophetic Literature," in Prophecy and Prophets:

The Diversity of Contemporary Issues in Scholarship, ed.Yehoshua Gitay (Atlanta: Scholars Press, 1997), 25.

${ }^{8}$ Peterson, "Rethinking the Nature of Prophetic Literature," 27.

${ }^{9}$ Peterson, "Rethinking the Nature of Prophetic Literature," 28-29.
} 
The message of the prophets could be predictive and in such cases there was often a covenantal basis and an opportunity for the hearers to experience divine blessing. At times, however, future events were simply outlined. Some prophecies gave no indication of the time-frame for fulfillment, and indeed did not come to pass in the lifetime of the prophet. Consequently, assessment of the prophet's authenticity, after the manner of Deuteronomy 18:22, could not appeal to the utterance being fulfilled. It must be noted that a positive response of the hearers in the form of repentance could avert a threatened outcome and so render a prophecy technically unfulfilled while, at the same time, completing God's purposes, as in the case of Micah 3:12. ${ }^{10}$

Freedman divides OT prophetic activity into two major phases. The first covers the period from Samuel to the disciples of Elijah and Elisha (the "sons of the prophets"). This time was characterised by messages which stressed the moral demands of God and the requirements of the covenant. The second spans the $8^{\text {th }}-5^{\text {th }}$ centuries $B C$, the time of the literary prophets. The basic truths of the earlier phase are here retained but the survival of Israel and Judah in the shadow of world powers comes into focus. ${ }^{11}$

The difference between Old and New Testament prophecy is that God related to Israel via the old covenant in the former, and the church, via the new covenant in the latter. While Israel was guided through prophecy to fulfill God's purposes, often in terms of their crisis relationship to other nations, the church is guided through prophecy to complete her mission of bringing revelation to the nations. ${ }^{12}$ Only specifically endowed individuals prophesied in the Old

\footnotetext{
${ }^{10}$ David Noel Freedman, "Between God and Man: Prophets in Ancient Israel" in Prophecy and Prophets: The Diversity of Contemporary Issues in Scholarship, ed. Yehoshua Gitay (Atlanta: Scholars Press, 1997), 61-64.

${ }^{11}$ Freedman, "Between God and Man," 67-69.

${ }^{12}$ Clifford Hill, Prophecy Past and Present (Crowborough: Highland Books, 1989), 171-172. William K. Kay, Prophecy! (Nottingham: Lifestream Publications, 1991), 64-66, finds evidence for a qualitative difference in pre and post Pentecost prophecies in Christian prophecy being subject to assessment, yet lacking a penalty if incorrect. He also lists three main functions of OT prophets: (i) to keep before the people the consequences of breaking the Law; (ii) aid the
} 
Testament; however, Paul makes it clear that any Spirit-filled believer can desire to prophesy. Unlike his Old Testament counterpart, the New Testament prophet does not speak to the community at large but only to the church. Previously, the prophet was an extraordinary minister of God, whereas now the prophet is an ordinary minister in the church of Christ. ${ }^{13}$ The Apostolic Church views contemporary prophecy to be identical to that of the New Testament era. Max Turner, however, details two points of dissimilarity between New Testament and contemporary prophecy, finding in the latter case an absence of distinctive forms of speech and a tendency towards simultaneous reception and transmission of the message. ${ }^{14}$ These observations of Turner's are not relevant here given that we will demonstrate the structural form of prophecy and refer

rulers of Israel; (iii) prepare Israel for the Messiah's coming. He notes that the OT prophet communicates frequently with Israel's king and, on occasion, pronounces judgement on a another nation. In contrast, the NT prophet has no interaction with the resident political power.

${ }^{13}$ Wayne Grudem, The Gift of Prophecy in the New Testament and Today (Westchester, IL: Crossway Books, 1988), 14-15, prefers to view present-day prophecy as a "very human - and sometimes partially mistaken - report of something the Holy Spirit brought to someone's mind." In his earlier work, The Gift of the Spirit in I Corinthians (Missoula, MT: Scholars Press, 1982), 71, he finds that NT apostles, as opposed to NT prophets, are the equivalent of OT prophets. Accordingly, the foundational apostles/prophets of Ephesians 2:20, as the counterpart of canonical OT prophets, formulated doctrine which became Scripture. In order to argue for continuation of prophecy in the NT, he therefore describes two forms of NT prophecy: authoritative or apostolic prophecy which ceased within the first generation and a "less authoritative type of prophecy indicated in I Corinthians." The Gift of Prophecy, 45-63. F. David Farnell, a cessationist, has responded in a four-part article, "Is the Gift of Prophecy for Today?" Bibliotheca Sacra 149/595 (July-September 1992), 277-303; 149/596 (October-December 1992), 387-410; 150/597 (January-March 1993), 62-88; 150/598, (April-June 1993), 171-202, wherein he denounces the bi-level prophetic expression and of course attempts to show that all prophecy ceased at the end of the apostolic age. Cessationists use Eph 2:20 in appealing to an argument-by-analogy viz, that the foundational ministry of apostles and prophets was for the first generation only and passed away at the end of the apostolic age. This view has its source in the polemics of the Reformers against the Papacy: by limiting the foundational gifts to the first century, the apostolic and prophetic authority of the Pope was undermined. Both Grudem and Farnell are attempting to protect Scripture and have thus followed the Reformers in their hermeneutical error. Jon Ruthven has dismantled the cessationist position in several publications and so no further treatment of that doctrine is necessary here. See Jon Ruthven's major work, On the Cessation of the Charismata: The Protestant Polemic on Postbiblical Miracles (Sheffield: Sheffield Academic Press, 1993) and his article, "The 'Foundational Gifts' of Ephesians 2:20," Journal of Pentecostal Theology 10/2 (2002):28-43.

${ }_{14}$ Max Turner, The Holy Spirit and Spiritual Gifts: Then and Now (Carlisle: Paternoster Press, 1996), 316-318.

Mark Cartledge reports that with charismatics there is an expectation that "prophecy is generally a spontaneous event." He also says that they have followed Pentecostals in viewing prophecy as a gift to be used in the congregational setting. In this he is correct, except that the Apostolic Church also finds a place for prophecy in church government, an exercise that is their defining feature. M. Cartledge, "Charismatic Prophecy: A Definition and Description," Journal of Pentecostal Theology 5 (1994): 88. Cartledge is supported in his assertion concerning 
again to the notion of the prophet "wrestling" with a message for a period before bringing it forth. ${ }^{15}$

Grabbe describes the mechanism of prophecy in a generalist way when he states that the "prophet is a mediator who claims to receive messages directly from a divinity, by various means, and communicates these messages to recipients." ${ }^{16}$ Aune provides a definition specific to the biblical context when he describes prophecy as "an intelligible verbal message believed to originate with God, and to be communicated through an inspired human intermediary."17 Nissinen admits that it is not an easy task to: distinguish prophecy from other oracular activity; identify an individual as a prophet; recognise any given text as prophecy. The prophetic nature of a text is in question, according to Nissinen, if the following three components of prophecy transmission are not evident in the text: a deity should be the originator of the words; the message should be addressed to a human; the message should be conveyed by a human prophet. $^{18}$

While Old Testament prophets sometimes used methods other than speech to convey their message, the primary medium of New Testament prophets was oral even if, on occasion, it was supplemented with a visible demonstration as in the case of Agabus binding Paul. Aune has five criteria for New Testament prophecy to be identified as such. The speech must: be of supernatural origin; contain specific knowledge; use formulaic language; be introduced by a qualification of the speaker; not conform to a literary

spontaneity of prophecy by D. McBain, Eyes That See (Basingstoke: Marshall Pickering, 1981), 88, and also C. Cousens, The Gifts of the Spirit (Eastbourne: Kingsway, 1986), 136.

${ }^{15}$ See above, Chapter Four, "Prophecy," 168.

${ }^{16}$ L. L. Grabbe, Priests, Prophets, Diviners, Sages: A Socio-historical Study of Religious Specialists in Ancient Israel (Valley Forge, PA: Trinity, 1995), 107.

${ }_{17}$ David Aune, Prophecy in Early Christianity and the Ancient Mediterranean World (Grand Rapids: Eerdmans, 1983), 339. Earlier (p. 82) Aune makes the useful distinction between prophecy as a verbal message and divination which he describes as the "interpretation of coded messages from the supernatural world conveyed through various kinds of symbols."

18 Martti Nissinen, Prophets and Prophecy in the Ancient Near East (Atlanta: Society of Biblical Literature, 2003), 8. 
classification. Using this schema he finds oracles which: announce salvation or judgement; predict the future; provide assurance; confirm ecclesial status; convey eschatological themes. ${ }^{19}$ Prophecy, as it is experienced in the Apostolic Church, is well described by Aune's categories as we shall see in the ensuing discussion.

A specific definition is provided by Boring who describes the early Christian prophet as "an immediately inspired spokesperson for the risen Jesus, who received intelligible messages that he or she felt impelled to deliver to the Christian community or, as the representative of the community, to the general public." 20 Witherington, however, finds fault with Boring's restriction of Christian prophecy to being the words of the risen Jesus; Boring's position requires the earliest Christians to not distinguish between the risen Lord and the Holy Spirit. $^{21}$ Clifford Hill describes prophecy in less specific terms as "the declaration of the mind of God in the power of the Spirit, with a special bearing on the current situation." 22 D. P. Williams, while not specifically intending to formulate a definition, has nevertheless provided one when he lamented that the wider church has ignored prophecy, changing the biblical meaning of the word and explaining it in terms of human intellect and natural ability instead of a "Divinely generated utterance through human lips by the indwelling Spirit of God."23

\section{Form of Prophecy}

For prophecy to function as intended it must first be recognised as revelation when it is brought forth: the delivery, content and form of speech

\footnotetext{
${ }^{19}$ Aune, Prophecy, 247-8; 317-8; chap. 10 passim.

${ }^{20} \mathrm{E}$. Boring, The Continuing Voice of Jesus (Louisville: Westminster, 1991), 83.

21 Ben Witherington III, Jesus the Seer: The Progress of Prophecy (Peabody, MA: Hendrickson Publishers, 1999), 321.

22 Hill, Prophecy, foreword.

${ }^{23}$ D. P. Williams, "Editorial," Riches of Grace 4, no 5 (1929): 150.
} 
help to identify it as such. ${ }^{24}$ In particular, formulaic expressions are used liberally in an effort to demonstrate the divine origin of the utterance. An analysis of prophecy transcripts from the New Zealand Apostolic Church council and executive meetings, 1965 to 1997 , show a similarity in the use of formulaic expressions. ${ }^{25}$ In general, all the expressions under scrutiny here appear consistently over the period of examination. The most common are now reviewed, with representative examples selected from different time periods.

'My servants' is the most prolific of the formulaic expressions and shows no variation in the frequency of use over time. Generally, it is used parenthetically which has the effect of highlighting the phrase, and therefore its meaning, which serves as a reminder that it is God who is speaking. Where the phrase is preceded by the word 'you', it becomes an intensifier as shown in the following: "And I want you, my servants, at this time to stir in my people throughout this land a new realisation of the wonderful inheritance that is theirs in the apostolic vision that I have given unto you."26 Prophecies which spoke to or about an individual always carried the 'my servant' prefix when identifying the recipient. The phrase was also used to refer to biblical characters, in which case it was adjusted to 'my servant(s) of old'.

'Even' is the single word most frequently appearing in formulaic speech. When used as an adverb, it can either compare an assertion with an implied but weaker one, or introduce an extreme case. The following excerpt shows the particle 'even' used correctly to stress the comparative degree: "Inwardly, even if not outwardly, I have seen the desire to stand before me in honour and

\footnotetext{
${ }^{24}$ Witherington makes the point that this is the case even if the content of the utterance is rejected, establishing prophecy as more than the articulation of ideas belonging to a particular group. Jesus the Seer, 12.

25 From the late 1990s prophecies brought at council and executive meetings were not transcribed, being replaced instead by a summary statement of the main points.

${ }^{26}$ Lewis Derry, transcript of prophecy, Executive meeting, Fielding, 6-7 July 1965.
} 
integrity." ${ }^{27}$ Here, the articles of comparison, 'inward' and 'outward' are both overtly stated. In the next example the comparison is between the hearer's implied current state of flexibility and a future improvement: "This will mean that at times you'll want to be even more flexible." ${ }^{28}$ A sub-heading in the use of 'even' as a comparator is to indicate something unexpected, as shown in the following: "But I will cause many more to arise in ways you do not expect, and even some in this place will move in ways they have not expected. ${ }^{29}$ A further use is as an intensive to emphasise or extend the identity or character of something: "I would bring some forward even quickly that there would be a sending out." ${ }^{30}$ In this excerpt 'quickly' is modified to reassure the hearers that this will truly be without delay.

What appears more frequently is the misuse of this adverb, functioning simply as a means to generate a sense of divine revelation, or to coin a linguistic term, a 'revelatory register'. Consider the following: "And even by my Spirit, as I would come and begin to stir amongst you . . . says your God."31 Based on the convention of comparison discussed above, a hearer would be led to understand that there is an implied, lesser means by which God can stir amongst his people. This next example emphasises the unexpected aspect where it is not appropriate because God expects Christians to be united with him: "For it is even my desire that you might have a place in me."32 The word 'even' is frequently overused, as the following example clearly shows: "The Lord would say even as my servant goes to Philadelphia this would be the beginning of many even in this room that I would begin to send out, says your God, because you were birthed even from a mission movement (emphasis

${ }^{27}$ Donald Lake, transcript of prophecy, Council meeting, 1997.

${ }^{28}$ Lewis Derry, transcript of prophecy, Executive meeting, Wellington, 20-21 June 1972.

${ }^{29}$ Lake, prophecy, 1997.

${ }^{30}$ Conor Candler, transcript of prophecy, Council meeting, 1997.

${ }^{31}$ Candler, prophecy, 1997.

${ }^{32}$ Lake, prophecy, 1997. 
mine). ${ }^{, 33}$ In this utterance only one instance is semantically required, viz. the specifying of those present unexpectedly being among the ones to be sent out. While it could be conceded that the phrase "even as my servant goes" is an example of 'even' combined with the subordinating conjunction 'as' to introduce an adverbial clause of time, familiarity to the prophet has presumably dictated its usage over the synonyms 'just as', 'at the same time as' or simply 'as'. It could also be argued that although the construction "even as my servant goes" might draw attention to the significance of his leaving, the meaning would be just as clear without it. Finally, "birthed even from a mission movement" incorrectly inserts the adverb in an attempt to further highlight the missionary origins of the movement. This attempt to generate an appropriate tone or desired effect is proliferated throughout the available prophecy transcripts, particularly amongst the more recent prophets.

Nominalisation of verbs to form a gerund is a common mechanism which focusses on the action inherent in the statement. Consider this example: "I would say as you release them, says the Lord, there shall come a multiplying, releasing and a magnifying of my purposes in this place."34 The alternative would have been to use the standard noun form, viz. multiplication, release and magnification, which conveys a far more static picture of God's involvement.

While prophecies at governmental level are given in the first person, the originator of the utterance is firmly identified by using the clause, 'says the Lord' or variations thereof including, 'says the Lord your God' or 'says your God' and, in the case of one prophet, 'says the Lord in the midst of thee'. Interestingly, in prophecies prior to the mid-1980s the only appearance of such a clause was at the completion of the message, whereas, in more recent prophecies the hearer is reminded throughout the delivery who the originator is. The archaic form,

\footnotetext{
${ }^{33}$ Candler, prophecy, 1997.
} 
'saith the Lord' was in vogue up until the early 1980s, the shift to contemporary usage possibly reflecting the influence of the NIV translation of the Bible which removed old verb forms. ${ }^{35}$

A number of formal, and in some cases archaic, words and phrases frequently appear, presumably to demonstrate the immanence of the source, the assumption being that God would not speak in colloquial language. 'At this time' is a circumlocution for 'now' or 'currently' but sounds considerably more dignified: "You are in a position at this time in which you must call upon the Lord." ${ }^{36}$ Similarly, employing 'midst' and 'amongst,' which are now little-used in common speech, generates a more official tone. 'Yea,' which has disappeared entirely from common usage, was still heard in prophecies in the early 1990s and some of the lesser-known prophets continued this practice well into the decade. Other phrases, while qualifying as circumlocutions, demonstrate a poetic element. 'New Zealand' is rarely, if ever, identified as such but is referred to as 'this land' or 'the nation'.

Words that describe an action or emotion expressed by God are also carefully chosen; for example, God does not 'want' to do anything, rather, he has a 'desire'. In the example that follows, the Lord's future action is couched in terms of Divine intention: "It is here that I desire to give my servants the opportunity of another chance, a second opportunity saith the Lord in the midst of thee."37 Up until the late 1970s, the predicative adjective form 'desirous' was often heard. Interestingly, the word 'desire' is also used to refer to motivation belonging to the hearers.

\footnotetext{
${ }^{34}$ Donald Lake, transcript of prophecy at Executive meeting, Auckland, 1-4 May 1995.

${ }^{35}$ Wayne Grudem believes that biblical prophets only, are qualified to append a "says the Lord" clause. Grudem, The Gift of Prophecy (Eastbourne: Kingsway, 1988), 167. At the other end of the spectrum, Mike Bickle is comfortable for such language to be used if the prophecy has exceptional clarity or the prophet is experienced. M. Bickle and M. Sullivant, Growing in the Prophetic (Eastbourne: Kingsway, 1995), 116.

${ }^{36}$ Wilfred Frater, transcript of prophecy, Executive meeting, 9-11 July 1968.

${ }^{37}$ Hone Maxwell, transcript of prophecy, Council meeting, Te Nikau, 21-23 November 1983.
} 
The sentence structure is often dramatic and deviates significantly from everyday speech, the most obvious example being the reversal of the usual order in the negative imperative. 'Do not look' becomes 'look not' and 'do not turn back' is rendered 'turn not back'. The construction 'that which' in place of the simple pronoun 'what' is regularly inserted and adds a degree of formality to the utterance as seen in the following: "I will equip you for that which you will find so challenging." ${ }^{38}$

Several phrases and some individual words have specific meaning in the context of prophecy. A 'new thing' in everyday speech could refer to any number of events or objects but in the spiritual context, specifically prophecy, it carries the meaning of 'a work of the Spirit previously not experienced'. In this early example the immediately preceding context was a promise from the Lord to provide light for his ministers: "And this is very closely associated with faith, for there will be times when I move upon you to do a new thing and this will test your faith, but the very exercise of faith shall become light to you." ${ }^{39}$

One word that holds particular meaning is 'release'. Conveying more than to set free or unfasten, 'release' incorporates the sense of fulfillment, spiritual breakthrough and realising potential. In the following example the manifestation of the release brought by the Lord is elaborated as unity of purpose: "Even as you have dealt with issues within the heart of this movement would I not say that it has brought release? And I would say that you shall see a great moving of my people as a company, says the Lord, at this time." ${ }^{40}$

It is apparent that prophets of lesser standing do not speak in the first person simple present tense but often use the subjunctive clause 'I would say'. Compare these two examples: "I look upon you purely as under-shepherds, and as the bishop of all souls I will require of you that responsibility that is

${ }^{38}$ Ray White, transcript of prophecy, Council meeting, 1997. 
subject to me. There is a need for you to surrender at this point that authority to me that I might bring you closer to myself."41 "I would say there are even aspects yet to be fulfilled of that which is locked up in the purposes of the Lord your God." $" 2$ The first excerpt is from a seasoned prophet operating towards the end of a 50 year ministry and demonstrates an ease with speaking on behalf of the Divine, whereas the second example, from a much younger man, conveys more of a tentative tone with an apparent reluctance of the prophet to speak directly for God.

Occasionally prophecies display particular features which are characteristic of an individual prophet. Repetition was the characteristic feature of Hone Maxwell as the following examples, drawn from a single transcript, show:

Men for you! Men for you! Men for you! . . . the name, the name, the name, . . . Are you the man? Are you the man? Are you the man? ... Where is the man who will stand before me? Who is the man to stand before me? ... For New Zealand, ah New Zealand, New Zealand, . . . For you have erred. You have erred. You have gone too far . . . be bold, be bold says the Lord, . . . crucified, crucified, crucified? ${ }^{43}$

The majority of the repetition is threefold and possibly reflects the influence of Maxwell's Maori heritage where such a linguistic feature is common in the context of oration.

The reiteration of salient points to either add emphasis or develop a thought, is a familiar feature of prophecies. This excerpt shows emphasis:

An experience that shall be lasting not just merely a flash today and gone tomorrow but an experience that will last; for I declare that there shall be some that shall come through the land and they will come with an experience that will not last, but I will give you an experience that will be lasting, an experience that will be an established experience. ${ }^{44}$

\footnotetext{
${ }^{39}$ Wilfred Frater, transcript of prophecy, Executive meeting, Auckland, 28-31 October 1969.

40 Lake, prophecy, 1997.

41 James Worsfold, transcript of prophecy, Council meeting, August 1984.

42 Donald Lake, transcript of prophecy, Council meeting, 1990.

${ }^{43}$ Hone Maxwell, transcript of prophecy, Council meeting, Te Nikau, 19 May 1986.

44 Lewis Derry, transcript of prophecy, Council meeting, Wellington, 29 Feb-2 March 1972.
} 
The following example of reiteration shows the development of an idea: "Therefore I say to you, be quickened again in the day of Apostolic power. Be quickened again in the day of Apostolic truth. Be quickened again in the day of the life and demonstration of that truth." ${ }^{.45}$

\section{Content of Prophecy}

While the hallmark of the Apostolic Church is divine government through apostles and prophets, the proportion of prophecy that provides detailed guidance on administrative matters is very small. The earliest governmental prophecy transcript available is from a 1965 executive meeting and contains little in the way of specific guidance or information. It expresses the thought that there would be an outreach to those outside the movement who are seeking the fulness of the Spirit. This is associated with the recurring themes of the Lord working in "unseen realms" and of his intention to "move." The message conveys the intention of the Lord to bless, his intervention which promises to collapse opposition, and concludes with encouragement to promote the "peculiar vision" given by the Lord to the movement.

The topic of this Apostolic Vision, as it was known, received further attention in a second prophecy later in the proceedings. The Lord promised that the "moving of my Spirit" would enable the council members to cope with the great responsibilities that would come upon them. Presenting the "fulness of the vision," which needed to be "born into every generation," would preserve the people from growing cold and enable the vision to be perpetuated. In what is perhaps the only specific instruction, it was stated that news of the Lord's moving and where his "blessing is falling" should be communicated to other

\footnotetext{
${ }^{45}$ Wilfred Frater, transcript of prophecy, induction service of J. E. Worsfold as President, Te Nikau, 22 October 1980.
} 
congregations within the movement so that all would be encouraged and not assume that God had departed from them. ${ }^{46}$

Much of the divine direction was of a general nature, encouraging a forward move in faith or a continued waiting on the Lord for example. Recurring themes include: the moving of God with attendant blessing; the call to remain firm and trust the Lord to fulfil his word; warning concerning activity of the enemy; the future of the movement including development of ministers; commentary on the state of the church and the world. Yet, it would be incorrect to assume that prophecies given in different situations were generic to the point of being interchangeable. While the overall construction is often vague, an underlying message is readily discernible in most cases. Consider this excerpt:

I will give to you yet another secret, for you will find that it is as you are overflowing that you will find the power and the strength that will carry you forward and you cannot overflow until you are filled and it is in this that I will have you to move in the fulness so that you shall overflow and in the overflowing there will be that which will attract others. There will be that which will indeed reflect the glory of the Lord. It is time, my servants, that there was more of the overflowing of my spirit in you and various ministries, and it is to this end that I will direct you, that you will seek the fulness to the overflowing and be not afraid of the overflowing for there are times when you have come to the point of overflowing and you have been afraid, but be not afraid of the overflowing because I declare that you will have a ministry of overflowing in the midst of my people, saith the Lord. ${ }^{47}$

A clear, concise alternative might have been: "You need the fulness of my Spirit to the point of overflowing in order to have power and strength and influence. Do not be afraid of an overflowing as you have been previously because I want you to affect people." The suggested summary has the benefit of being constructed from a transcript and, not being subject to a stream of consciousness, is correspondingly devoid of some of the mechanisms of delivery normally utilised to authenticate the divine nature of a prophecy.

\footnotetext{
${ }^{46}$ Derry, prophecy, 6-7 July 1965.

47 Wilfred Frater, transcript of prophecy, Executive meeting, Wellington, 25-26 \& 28 February 1972.
} 
The divine-human mix of prophecy could become heavily weighted towards the human when addressing issues which directly affected the prophet. We have previously noted that the ordained prophets were singularly unsuccessful as pastors and therefore stood to gain immeasurably from the centralisation of finances. Lewis Derry prophesied at an executive meeting that:

In the past there has been a sense of a lack of confidence in peoples in various parts of the country, but I have come to speak to you at this time, that you will move to this end that my people will have a renewed confidence, a restored confidence and that they shall be able to accept with joy the way in which you administer that which pours into the storehouse. $^{48}$

The prophet could be involved in the appointment or relocation of personnel. However, it was not unknown for a prophecy to ratify a decision after the fact as in this case: "For I would speak and I would say at this moment that it is indeed my will for my servant Belcher that he shall go even as you have decided to Dunedin. And again for my servant Pearson to go as you have agreed, to Christchurch." 49 It is not clear whether the prophet thought that such resolutions needed confirmation or whether he imagined that a prophet should have had a part in the decision-making. A more troubling observation is that the prophet endorsed as God's will decisions which, at least in the case of the Dunedin assembly, went against the wishes of the incumbent and proved to be disastrous for the congregation.

In terms of numerical strength, the Apostolic Church has, for at least the last 30 years, been in the shadow of the larger Assemblies of God movement, a fact which seems to have prompted the prophets to occasionally attempt an explanation of this state of affairs. The Apostolic vision was heralded as the answer to the conundrum; Lewis Derry prophesied that the flourishing of other denominations should not bring confusion because the Lord was working in

\footnotetext{
48 Derry, prophecy, 25-26 \& 28 February 1972.

${ }^{49}$ Lewis Derry, transcript or prophecy, Council meeting, Wellington, 2-8 \& 16 April 1968.
} 
their own "midst." He continued, reassuring that the movement would not always be small and then said: "I have a greater purpose for you in this land as a church and that it shall come to pass that people shall run towards assemblies in various parts of this land to see and to know what the Lord is doing in them." Despite the anticipation, the influx did not eventuate, the charismatic renewal developing along its own lines without significant reference to the Pentecostals in general or the Apostolics in particular.

Much of the non-specific content of prophetic utterances could be classified as statement of general truth applicable for any situation, a common theme centreing on reassurance that God was active in the outworking of, as yet, unrevealed plans. The prophet frequently found it necessary to draw attention to these facets of divine activity despite the fact that if God were not leading and guiding his ministers and being otherwise active in the unseen realm, then their service to Him was of no value. Vague predictions of divine movement appear to be part of a standard repertoire: "There shall be movements of my Spirit in these days . . Because you trust me I will move upon you not only now, but many times." ${ }^{11}$ However, not all promises are gratuitous; conditions apply in some cases. One prophecy identified total surrender as a condition which, when fulfilled, promised that the hearers would "indeed come into this greatest move of my Spirit. I will be able to entrust you with my power says the Lord." ${ }^{25}$ Seven years later the same prophet, having challenged the council members to make sacrifices in their service for the Lord, prophesied: "I promise on the basis of my faithfulness that you will experience the rewards, you will experience the joy of harvest." ${ }^{\text {53 }}$

\footnotetext{
${ }^{50}$ Lewis Derry, transcript of prophecy, Executive meeting, Auckland, 6-8 March 1973.

${ }^{51}$ Frater, prophecy, 28-31 October 1969.

52 Jack Guerin, transcript of prophecy, Council meeting, 1990.

53 Jack Guerin, transcript of prophecy, Council meeting, 1997.
} 
Any content of a prophecy designed to reveal specifics may be embedded in analogy, the meaning of which, if not easily inferred, opens up numerous interpretative possibilities. In the example that follows, the prophet's use of analogy tends to obscure the intended meaning. After enjoining the listeners not to look to the past, they are directed to "raise up a new generation of those who will serve me in this land " the reason being that:

It has been as if you've tired yourselves on the field and a great crowd has awaited for the call, says the Lord, to come and appear upon the field. And the call has never arisen. But today my servants I call upon you to arise with that call in your heart, to let a new crowd arise on the field, says the Lord, to take your place, says your God, on the playing field in the centre of attention in the process and purposes of the Lord your God, for I desire them now to pick up that which you have carried over many years.

There follows the observation that those who have been involved with the council for many years prefer the old ways; however, God was doing a "new thing" and it was time to take hold of it. The prophet returned to the analogy: "Allow those that I am calling to crowd onto the field, even as it were, at the end of a match when they arrive and the field is full of people and the play cannot continue..54 Presumably, the prophet did not intend to convey that the time of the Apostolic Church had drawn to a close or that he was predicting the return of Christ; rather, there was a strength of numbers in those willing to carry on the work.

Prophecy which directs personnel to a new location or position has been one of the defining features of the Apostolic Church. It is in this arena that prophecy has its greatest potential for expedience or abuse. Some effects of misguided directional prophecy have been documented in the previous chapter; of interest here is the relationship of the prophetic to personnel relocations and appointments which find their impetus in personal agenda. It has to be said that the cases of greatest travesty were not the result of bogus prophetic input;

\footnotetext{
${ }^{54}$ Lake, prophecy, 1997.
} 
however, on such occasions the prophet is damned on account of his silence. It has already been noted that prophetic revelation was frequently given as a rubber stamp for the decisions of the apostles, some of which were direct outworkings of individual ambition.

When it came to directives issued to personnel it would appear that, on occasion, the prophets were not totally assured as to the authenticity of their message. This is particularly the case with what might be called the "second string" prophets. Consider this instance where the prophet has God acknowledging, in a somewhat defensive manner, the apparent unsuitability of his choice: "I want you to appreciate also that my hand is upon my servant Dickie and move him from this place, even at this time, to re-establish him in a large assembly which to you may seem to be a rather contrary move but I would assure you, my servants, that my hand is upon him." In contrast the prophet had, a few sentences earlier, enunciated "it is indeed my will" for a nominated minister to go to California and, regarding another younger man, "that he shall be ordained pastor in the flock." 55 The uncertainty on behalf of the prophet with regard to his message is clear in the next example where the prophecy, directed to another pastor, quickly downgrades firstly from an authoritative utterance to an aside to the hearer, and then to a suggested commentary on the situation:

My servant lan, I would release you from any sense of blame regarding Owen and Joy. I don't know if this clicks lan, but I just feel the Lord saying "if there is any trace of blame, condemnation, that you are to be released from it, that they are God's. They have made their choices, they are still God's servants and you are to be totally free from any sense of blame in the situation." 56

The problem of a fluctuating level of inspiration is one that has remained although, as noted earlier, only among the less senior prophets. In the following

\footnotetext{
${ }_{55}$ Peter Galletly, transcript of prophecy, Council meeting, Wellington, 19-21 March 1974.

${ }^{56}$ Guerin, prophecy, 1990.
} 
case the speaker, Conor Candler, had spoken strongly, in the first person, concerning the national training centre. Candler, himself a recognised prophet, then moved onto the topic of reassessing who should, in fact, occupy the office of prophet and in so doing changed to commentary in the third person, prefacing his comments with: "I believe the Lord would want to speak regarding the prophets." He pointed out the effect on the authenticity of prophecy if prophets have too much human knowledge of situations and continued, "I have to say this by faith, that Ray and Charles, God is saying that you need to seriously consider the call of the prophet on your life" suggesting the alternatives of missionary and pastor respectively. ${ }^{57}$

That prophecy is "channel-dependent" is most obvious when thoughts expressed reflect unusual or aberrant theology. We have already shown several examples where the enunciated thought is unlikely to be a concern of the divine. Similarly, predicted actions of the Lord which are not in line with New Testament revelation signify the frailty of the message, as the following example demonstrates: "I bless those who receive my word and I will curse those who will not receive my word, in the midst of thee."58

\section{Functioning of Prophecy}

The apostle and prophet ministry which was exercised from time to time in various regions throughout the 1960s received a boost from the deliberations of the national council in 1967. Prophetic revelation via L. J. Derry during the council meetings stated that, "I desire that apostles and prophets shall work together . . your ministries shall combine and your ministries shall produce something together, not as separate ministries." This encouragement, coupled with positive reports of previous efforts in this regard, led to the development of

${ }^{57}$ Candler, prophecy, 1997. Both Ray White and Charles Nikora functioned in prophecy at the 
the practice whereby one of the national prophets would travel with an apostle, who was also an executive member, to a particular assembly at the invitation of the local pastor. ${ }^{59}$

On the same day as Lewis prophesied, J. W. Keane brought a strong word which sought to redress an imbalance in the church, namely, the relegation of the prophetic at the hands of the apostles. He prophesied, "Don't be afraid of my word for even as you call yourselves an Apostolic Church, for too long you have been apostolic and not enough prophetic. But I declare to you don't be afraid that the prophetic will outdo the apostolic." Keane's word looks into the psyche of the apostles, perhaps unearthing the deepest fear, when he continues, "My servants the apostles, don't be afraid that the prophets will bring to you words that you are unable to handle." The issue seemed to be one of lost confidence between the apostles and prophets, Keane prophesying that the "confidence of my servants" had been "shattered" over time through various experiences.

In what was presumably intended to allay fears, Keane prophesied that “you won't find yourselves in awkward situations, such as you have been saying could confront you." However, in this he is most probably presenting natural knowledge as being divine in origin given that God is unlikely to bring revelation after the manner of an eavesdropper. Keane continues, and links not only the cause but the remedy for the lack of numerical growth to the issue of suboptimal operation of apostles and prophets, promising that God will "add to the church, my servants, just as soon as you find your place in this vital ministry in my word." Keane employs anthropomorphism when he prophesies "I have seen the stagnation indeed in the numbers." The probability of God taking an interest in the attendance figures of the church is remote, at least expressing his 
concern in such terms. Rather, the Lord is likely to be concerned with the advancement of his kingdom, which may, at a superficial level, be reflected in attendance statistics. ${ }^{60}$

The potential for prophetic messages to overly reflect the human component did not escape one UK Apostolic Church writer, T. N. Turnbull. Writing on the necessity for prophetic words to be judged, he stated that this was the role of both an apostle and other prophets. The apostle was to evaluate messages on account of his primacy of office, and other prophets should do likewise due to Paul's reference, in his letter to the Corinthians, to the "others" weighing what is said. ${ }^{61}$ Turnbull offered several reasons why prophecy may be assessed as uninspired. The prophet may: be influenced by church events; begin his delivery "in the Spirit" and conclude "in the flesh;" be over-zealous. $^{62}$

An ordained prophet speaking at government level would not be expected to utter completely erroneous prophecies. The previous chapter records some events where weak prophecies surfaced within council and we have pinpointed the problem of the apostles' and prophets' personal agendas affecting their assessment and subsequent decision-making. There is little recollection amongst the older members of the pastorate of such difficulty in the early days of the Apostolic Church in New Zealand. The reasons for this are threefold: the extremely small size of the movement made it less likely for factions to exist within the leadership; the first church officers who emigrated from the United

\footnotetext{
${ }^{58}$ Maxwell, prophecy, 21-23 November 1983.

${ }^{59}$ Minute 6, Council meeting, Wellington, 14-17 February 1967.

${ }^{60} \mathrm{Jim}$ Keane, transcript of prophecy, Council meeting, Wellington, 15 February 1967.

${ }^{61}$ Gordon Fee interprets oi $\alpha^{\prime} \lambda \lambda$ ol of I Cor 14:29 to mean "the rest of the same class" i.e., the other prophets. F. F. Bruce, ed., The First Epistle to the Corinthians, NICNT (Grand Rapids, Michigan: Eerdmans, 1987), 694.

${ }^{62}$ Thomas N. Turnbull, Prophecy in the Church Age (Bradford: Puritan Press, 1971),66.
} 
Kingdom came with a missionary zeal to outwork the "Apostolic vision"; in the early days prophets were held in higher regard. ${ }^{63}$

Craig Clements, National Leadership Team (NLT) member, posits that only the successes of yesteryear have been reported. ${ }^{64}$ Consequently, present day observers are left with the impression that the prophecy of the earlier times was of a higher grade. Perhaps it was: certainly prophecy was appealed to more frequently and on a wider range of issues. It stands to reason that if a divine gift is used more often, then, on a statistical basis alone, accurate prophecies will be produced in greater number.

James Worsfold, writing the President's column in a 1986 issue of the church's national newspaper, expressed concern that many of the Apostolic Church prophets were "unaware of the richness of our prophetic history and therefore have been unable to take their cue from our own firmly based historical revelations." Given that in the same article he described such prophets as distanced from the main stream of Apostolic prophecy and influenced instead by charismatic contagious prophecy, his comment on their missing the historical revelations must refer to their failure to follow guidelines which had grown up around the practice of prophecy, that is, the purpose, operation and themes as stated by D. P. Williams and others who followed him. Worsfold considered charismatic contagious prophecy as "lightweight," being of a motivational nature and with a propensity to be spoken over individuals, the so-called personal prophecy. Consequently, charismatic prophecy was not considered of sufficient substance to operate at the level of church government.

\footnotetext{
${ }^{63}$ It would be an incomplete picture to portray those original expatriate church officers (A. L. Greenway, A. Gardiner, J. F. D. Thompson, J. D. Eynon) as totally virtuous men without any disposition for seeking personal benefit. When New Zealand-born council member Cecil Scadden enquired from NZ president, J. D. Eynon, why only expatriates were sent to the Penygroes convention (at the expense of the NZ church), he was told that the rigorous itinerary of UK assemblies expected of visiting ministers would "kill you." This rorting of the system by the expatriates proved to be a bone of contention for many years. Cecily M. Worsfold to Luke Worsfold, 6 January 2004.

${ }^{64}$ Craig Clements, phone interview with Luke Worsfold, 8 October 2002.
} 
While detachment from the Apostolic main stream may have led some down the charismatic route, Worsfold observed that others revert to the ministry they had before they were recognised as prophets and therefore operate at the level of edification, exhortation and comfort. Prophecy intended for use in government of the church requires the element of direction and so necessarily has to extend beyond the three functions which Paul outlined for the congregational setting in Corinth. ${ }^{65}$

In the same article, Worsfold spells out the role of the apostle in prophecy, viz. to discern and, if necessary, judge the utterance so that the church is preserved in truth. No prophet, he wrote, should ever be considered infallible. ${ }^{66}$ However, he drew attention to the divine-human mix in prophecy being overemphasised with the result that "deep and mysterious prophecy" is considered by the apostles to be "simply fascinating puzzles which remain unsolved." It is at this point that the role of exposition of prophecy is highlighted. He does not elaborate further on this apostolic gift apart from identifying it is an extempore

\footnotetext{
${ }^{65}$ As already stated in this chapter, for the Apostolic Church current prophecy is to be equated with that of New Testament times. An individual could be set apart by ordination for the operation of prophesying; such men were known in the early days of the New Zealand Apostolic Church as a "set prophet." This ordained prohet could be expected to speak, under divine inspiration, to the denomination's leaders on matters of government. The level of authority that these prophets assume in their utterance is reflected in their practice of prophesying in the first person singular. The notion of the "set prophet" was a point of theological departure between the Apostolic Church and both the AoG and Elim movements. Prophecy has always been a feature of both these latter two mentioned denominations; however, in the Elim Church it was predominantly delivered in the third person singular. The AoG in New Zealand experienced little prophecy in their early days, tongues and interpetation being exercised far more commonly. This situation persisted until UK AoG minister Howard Carter, whilst visiting New Zealand, addressed the AoG Bible School led by C. C. H. Scadden and encouraged the increased use of prophecy. Older channels of prophecy in the AoG are comfortable delivering their utterances in the first person singular; however, newer channels are more likely to use the third person singular. It is interesting to note that within the AoG individuals are now being identified as "prophets." Theologically there is no difference in the way the Apostolic Church, AoG or Elim understand the validity, function and operation of prophecy. All agree that it is a gift which can follow on from Spirit-baptism and that it should take a predominant place in the life of the church. The governmental use of prophecy characterised the Apostolic Church and has, in the past, been a point of contention separating the movement to some extent from her closest ecclesial neighbours. The isolation has only abated, it seems, since prophets have begun to be recognised in New Zealand's largest pentecostal church, the AoG. Stan Hewitt (first generation member Elim Church, NZ), lan Clarke (former AoG General Secretary), Neil Hetrick (AoG General Secretary), Gwen Knauf, interviews with C. M. Worsfold, Wellington, 2006.
} 
ministry distinct from preaching, which constitutes more than simply commenting on an utterance. ${ }^{67}$

We have previously noted that D. P. Williams was extremely able in this regard and a brief analysis of some of his published efforts reveal the following principles: certain themes in the prophecy would be highlighted and developed after the manner of a sermon; some themes in the utterance could serve as a springboard for development of related topics not mentioned in the prophecy; appropriate biblical texts would be expounded; down-to-earth analogies were occasionally provided on various points. It is apparent from the published transcripts of prophecies and the corresponding expositions given at the annual Penygroes convention that the sermonic exposition could frequently exceed the prophetic utterance in length. Certainly, the exposition translated the often poetic language of the prophecy into readily understandable terms for the hearers and placed the message in a context that enabled it to be absorbed.

Exposition of prophecy, where it occurs at all, is conducted in a far more limited way in New Zealand congregations. Up until the 1980s it was still a feature of the national annual pastors' conference held in the Wellington area. ${ }^{68}$ In the setting of a national council meeting, the prophecy necessarily takes on a directional tone and the exposition is a function of the apostles' deliberation. Here again, the weight afforded to prophetic utterance is variable, the apostles now relying more on the consultative approach to government than complete response to the "word of the Lord." 69

Worsfold projected that the Apostolic Church would fulfil its calling if attention were given to developing the ministry of apostle and prophet as

\footnotetext{
${ }^{66}$ An excerpt from The Apostolic Church, Its Principles and Practices (Bradford: Puritan Press, 1937), 130 states: "We do not believe in the infallibility of prophets, because, as men, all are liable to fail."

67 James E. Worsfold, “The Apostle Prophet Function," Apostolic News (August 1986): 2.

${ }^{68}$ Rex Meehan to Luke Worsfold, 6 January 2004.

${ }^{69}$ See above, Chapter Four, "Prophecy," 156.
} 
opposed to "trying to become another successful pentecostal church." Interestingly, he felt that a widespread acceptance of the apostolic gifts across denominations would see the weight of argument for separate existence of the Apostolic Church begin to diminish. ${ }^{70}$

The question for the Apostolic Church is: "To what extent is the government of the church prophetically driven?" The highest operation of divine government must be prophetic activity in appointing apostles or prophets. The cessation of this practice is understandable on several accounts. ${ }^{71}$ Firstly, the character of prophecy has diminished and may not necessarily be relied upon to bring forth names for ordination to these offices. Secondly, the expansiveness of the movement means that centralised decision-making in respect of appointment to office can be perceived as being "out of touch." Local congregations want autonomy and do not relish direction from remote and uninformed persons who possess the authority to affect their future. The alignment of local pastors with particular supervisors who have formed a networking relationship with other ministers in the movement means that revelation from a nationally recognized prophet may not be received if that prophet is outside of the recipient's network.

Another point to consider is the motivation amongst pastors to promote prophecy in their public congregational gatherings. In these settings there exists what may be described as a "faith dynamic" which can be directed by the pastor in several different ways, one of which is the expectation of prophecy. Other pentecostal groups most often orient this faith dynamic toward healing or evangelism and it is this practice that has probably influenced Apostolic Church pastors in recent times. These other manifestations are good for church growth

\footnotetext{
$\overline{70}$ Worsfold, "Apostle Prophet," 2.

71 See above, Chapter Four, "Prophecy," 164-165.
} 
and so prophecy, while still considered valid, tends not to be a priority as it was in earlier years.

The Apostolic Church relies on the accounts in Acts to mandate its prophetic activity at the level of church government. Agabus predicts a famine in Judea (Acts 11:28) prompting the leaders to initiate a fund in anticipation of the event. Years later, while in Caesarea, Agabus predicts Paul's arrest and imprisonment in a manner reminiscent of Ahijah the Shilonite who rent his cloak to demonstrate the impending disruption of Solomon's kingdom: Agabus binds his own hands and feet with Paul's belt announcing that the Jews of Jerusalem would bind and deliver Paul to the Gentiles. At first glance it appears that Agabus got it wrong in that the Gentiles initially save Paul from the Jews; however, it was the Romans who eventually executed Paul. Authentic predictive prophecy of a specific nature, as opposed to general statements of God's intention, are as rare now as they were in the New Testament. A difficulty arises when circumstances are made to fit the prophetic details; rationalisation can force a false conclusion. Of greater significance for the Apostolic Church are the biblical examples where the prophet outlines the immediate will of the Lord, especially in regard to ministries. At Antioch when Barnabas and Saul are set apart for the Lord's work, the Holy Spirit is identified as the author of that decision (Acts 13:2); the Apostolic Church has always understood that the mechanism for conveying the mind of the Lord in this case to be prophecy. ${ }^{72}$ Barnabas and Saul are subsequently recognised as apostles through an autonomous decision of the Antiochene leadership, and it is from this point that we see the rise of the Antiochene church and her apostleship.

Paul's decision to attend Jerusalem for the Council was by "revelation" which could be a reference to prophecy (Gal 2:2). It was during this first 
Jerusalem Council meeting that the prophets Judas and Silas assist in the formulation of apostolic decrees on matters of diet and circumcision; they then accompany the letter which summarised the deliberations for the Antiochene church. Here the prophetic word augments the written. Luke records that the prophecies were lengthy; it is apparent that the topic required more elucidation, as Peter's confusion later demonstrated, which perhaps accounts for the need for more revelation in this instance. Following the split in the founding Antiochene apostleship, Paul chooses Silas the prophet as his travelling companion. On Paul's second missionary journey Silas provides him with direction concerning where or where not to preach, a practice which ultimately resulted in the first European convert, a woman from Thyatira, but also a church plant in Philippi. The New Testament example is one of valid prophetic exercise producing discernable results. ${ }^{73}$

\section{Weberian Analysis}

In Weber's understanding, "charisma" is the quality which identifies an individual as a leader in the eyes of his followers. Weber sourced the idea of charisma from the NT usage which refers to the divine endowment of people with extraordinary abilities; however, he substituted for its religious meaning a

\footnotetext{
${ }^{72}$ Worsfold, "Apostle Prophet," 2. This point of view is also shared by F. F. Bruce, Commentary on the Book of The Acts, NICNT (Grand Rapids: Eerdmans, 1984), 261.

${ }^{73}$ This was not to remain the norm for the church, however, there being a decline in prophecy following the apostolic period which Aune attributes to adverse reaction to the Montanists. Aune, Prophecy, 338. Hill states that there was no "major movement emphasizing prophetic revelation" from the time of the Montanists' demise to the beginnings of the Pentecostal movement. Hill, Prophecy, 263. Witherington goes as far as to say that after the second century $A D$, Christianity cannot be considered a prophetic movement and that prophecy was shunned due to its association with the heretical Montanism. Witherington, Jesus the Seer, 395-6. It is interesting to note that Montanists were criticised not for their eschatological teaching per se but for the challenge to authority and the radical asceticism which derived from their expectation of an imminent parousia. Contributing factors were, no doubt, the prominence given to women and the deviation from tradition. Opponents to Montanism believed that the inspired lost control of their faculties when prophesying, as evidenced by the statement of Epiphanius who contrasted Montanists with OT prophets saying that the latter were "in possession of their understanding when they uttered their prophecies." The Panarion of Epiphanius of Salamis, bk. 2, sec. 48.3.3-6, trans. Frank Williams (Leiden: E. J. Brill, 1994), 9.
} 
sociological one which referred to the capability of a leader to draw to himself devotees. He defined it thus:

The term "charisma" will be applied to a certain quality of an individual personality by virtue of which he is set apart form ordinary men and treated as endowed with supernatural, superhuman, or at least specifically exceptional powers of qualities. These are such as are not accessible to the ordinary person, but are regarded as of divine origin or as exemplary, and on the basis of them the individual concerned is treated as a leader. ${ }^{74}$

He follows his definition of charisma with a statement reinforcing the notion that, in terms of charismatic authority, how such an individual is regarded by his followers is of utmost importance. To maintain legitimacy the charismatic leader must repeatedly demonstrate his power; this reliance on authentication ensures the unstable nature of charismatic authority. ${ }^{75}$ Weber elsewhere states that he has defined charisma in a value-free way: ${ }^{76}$ that is, he does not necessarily think the observed interaction is good, it is merely a description of how things are. It is possible, however, that Weber had a special regard for charisma in that it is the only example he offered as a challenge to rationalisation occurring in history.

While the authority which these powers conveyed was deemed not to be from the realm of the mundane or the profane, ${ }^{77}$ the basis of the charismatic community is only the bonds of personal loyalty and these emotional bonds are insufficient to form a stable congregation. If the community is to become anything more than transitory then the charisma-based authority must be replaced with rational authority. This unavoidable transition from charismatic community to a stable religious congregation Weber described as routinisation of charisma. Once the founder has died it becomes necessary to institute

\footnotetext{
${ }^{74}$ Max Weber on Charisma and Institution Building: Selected Papers, ed. S. N. Eisenstadt (Chicago: University of Chicago Press, 1968), 48.

${ }_{75}$ Charisma and Institution Building, 22, $49 f$.

${ }^{76}$ Charisma and Institution Building, 19.

77 Charisma and Institution Building, 51.
} 
rational processes to maintain functioning of the community. ${ }^{78}$ As charismatic authority is gradually supplanted by alternate forces, new standards are created so that innovation can come via routinisation and not solely through charisma. An obvious example is the Christian Church, which emerged from the movement led by the charismatic figure of Jesus.

Yet, despite apparent objectivity it is possible to find in Weber a tension between the natural progression towards organisation and charismatic fervor, particularly in his analysis of society and economic relations. He observed that the impact of charisma on the social order weakens once bureaucracy has become established. With regards to party politics the bureaucratic machine effected the "castration of charisma."79 Perhaps one of the strongest examples of a negative connotation being expressed is Weber's treatment of "the position of the official." He notes that the bishop, priest, and preacher of his day, in contradistinction to the early Christian period, no longer demonstrate "purely personal charisma." The "supra-mundane and sacred values which they offer are given to all. He remarks that previously leaders operated under direct instruction from their master and while this idea still survives in part, leaders of his day are "officials in the service of a functional purpose" which has become routinised and "idealogically hallowed." 80 It seems that here Weber is critical of the way forms of religion which, elsewhere he has described as essential to preservation of the movement, have not only become ends in themselves but have assumed sacred significance.

Weber believed that charisma, because of its non-routine nature, existed "only in the process of originating." ${ }^{81}$ With the passage of time the enthusiasm

\footnotetext{
${ }^{78}$ Max Weber, From Max Weber: Essays in Sociology, ed. H. Gerth and C. Mills (New York: Oxford University Press, 1946), 245-252; 262-264.

${ }^{79}$ Max Weber, Economy and Society: An Outline of Interpretive Sociology, eds Guenther Roth and Claus Wittich (Berkeley: California University Press, 1978), 1132.

${ }^{80}$ Charisma and Institution Building, 70.

${ }^{81}$ Charisma and Institution Building, 54.
} 
created by the founder wanes as organisational routine comes to preoccupy the followers:

Every charisma is on the road from a turbulently emotional life that knows no economic rationality to a slow death by suffocation under the weight of material interests: every hour of its existence brings it nearer to this end. $^{82}$

Weber found in history a tendency for the decline of charisma:

It is the fate of charisma to recede before the powers of tradition or of rational association after it has entered the permanent structures of social action. This waning of charisma generally indicates the diminishing importance of individual action. ${ }^{83}$

Nevertheless, Bendix remarks that "this 'decline of charisma' is less the statement of a trend than the explication of a term." ${ }^{84}$ Weber attempts to simply describe the process he observed of charismatic practices being replaced by other forms. His primary purpose is not to associate charisma with all things progressive and dynamic while identifying routinisation with retarding and static forces. Rather, charismatic and routine aspects of social organisation should be viewed as points of transition instead of positions of polarity, and their interrelationship analysed accordingly.

Weber also describes his routinisation pattern in terms of a transition from a prophetic movement to a priestly institution. The prophet, with his new revelation, initiates change, and the priest codifies the revelation in an effort to maintain the new religious system. Correspondingly, the prophet has the genuine charisma whereas the priest has a derived authority known as "office charisma" which can be transmitted via ritual. ${ }^{85}$ The prophet and priest are viewed as two opposing types that appear in succession, the priest replacing the prophet. The prophet's focus is total orientation toward God whereas the

\footnotetext{
82 Economy and Society, 1120.

83 Economy and Society, 1148.

${ }^{84}$ Reinhard Bendix, Max Weber: An Intellectual Portrait (London: Heinemann, 1960), 328.

${ }^{85}$ Economy and Society, 439, 1139.
} 
priest has an emphasis on external acts and obligations. ${ }^{86}$ We might note in passing that the New Testament, at various points, is content to designate Jesus as prophet, priest and king. The prophet and priest are complementary functions: the prophet represents God to man, the priest man to God. St Peter informs all Christ's followers that they are a "royal priesthood" (I Pet 2:9). As such it can be shown that they are to reflect the holiness of their high priest, offer spiritual sacrifices, and intercede for man - all functions which require charismatic endowment.

When applied to Christianity the routinisation theory does not fit at all points. On account of the ascension Jesus might reasonably be described as having departed Earth, yet Christians would attest to his continuing presence. Evangelicals speak of being "born again" and the Spirit of Christ taking up residence within them. Add to this the pentecostal doctrine of Spirit-baptism as a result of Jesus' promise to "send the Advocate" and the notion of a Christian devoid of the founder's company is false. Yet Weber may have found in the Roman Catholic Church of his day examples of doctrinal rationalisation, ritualism and legalism replacing belief, worship and ethics respectively, thus demonstrating to him that routinisation of charisma was occurring. Certainly there are many facets of the Christian church which fit Weber's description of routinisation and in this regard the Apostolic Church is no exception.

There is ample evidence of true Weberian routinisation in Apostolic Church history, as the following few examples show: ordination of officers, training of pastors and missionaries, establishment of a system of government, national conventions, denominational publications, and of course the event which epitomises routinisation, the formulation of a constitution. This is the

\footnotetext{
${ }^{86}$ Max Weber, Sociology of Religion (Boston: Beacon Press, 1963), 46-79.
} 
expected development and provides a mechanism for persisting innovation beyond that of the original charismatic leader.

D. P. Williams, as founder of the Apostolic Church, operated with the prophetic charisma as Weber understood the term. The formulation of the Constitution in 1937 presents as a definite transition point from charisma to routinisation for the UK church especially. Two periods stand out in New Zealand Apostolic Church history as deteriorations of charismatic authority: the 1960s when centralism was an immovable force, and the late 1980s and early 1990s when the movement was managed rather than led.

While there is evidence of routinisation in the Apostolic Church, there are features which suggest that it is not as far reaching as Weberian theory would suggest. Perhaps the Apostolic Church's most protective feature in guarding against the negative features of routinisation is the practice of ordaining men to the office of prophet. While ordination is an expected activity in the maintenance of such an organisation, i.e. an example of routinisation, it is the ongoing recognition of the prophetic office which protects against a decline of charisma. In such a move provision is made for the continuing word of Christ (the founder) to be heard. Weber's example of apostolic succession whereby charisma is transmitted to the new priest on account of the charisma of the office and not on the worthiness of the incumbent, i.e. his depersonalisation of charisma, ${ }^{87}$ is a quite different idea to that carried out in the Apostolic Church. In the latter, it is exactly the personal worthiness of the ordinand which is in view, the process of ordination being seen as only a recognition of grace operating in the individual as evidenced by his prophetic expression. The potential for the charismatic community to receive direct words from the Lord via prophetic utterance works against the tendency to settle for a codified routine. 
The prophet has the ability to bring revelation which will continually initiate change within the religious community. In that way, the founder's mind-set of challenging the status quo persists in his followers. However, the history shows that revelation from the prophet was not always handled correctly, at times not even sought after and at other times sub-standard in its quality. These episodes coincide with the observed periods of what might be called "charismatic corruption," a concept which moves beyond Weber's idea of routinisation.

Werner Stark, a secular Jew who converted to Catholicism, devoted some of his academic energy to argue for the persistence of charisma in the Roman Catholic Church. Stark found fault with Weber's individualism: while Weber recognised individual charisma in founding a religious collective he did not conceive of the process operating in reverse, that is, the religious collective cultivating individual charisma. $^{88}$ Stark enumerates several arguments, drawn from Roman Catholic theology and praxis, in support of his notion of a collective charisma. $^{89}$

Using Stark's basic ideas and making appropriate adjustments to apply them to Protestantism, or more specifically the Apostolic Church version of Pentecostalism, it is possible to construct an argument for the persistence of charisma in the movement under review. ${ }^{90}$ Over and above the regular charismatic expression previously described, from time to time there arises in the church particular individuals who are extraordinarily gifted, as evidenced in

\footnotetext{
${ }^{87}$ Depersonalisation of charisma is the process by which charisma becomes detached from the charismatic leader and transferable, acquirable or attached to an office. Economy and Society, 1135.

${ }^{88}$ Werner Stark, The Sociology of Religion: A Study of Christendom (New York: Fordham University Press, 1966-1972), 4: 6.

${ }^{89}$ Stark, Sociology of Religion, IV 5, 161, 197.

${ }^{90}$ Two points, drawn from Stark's work, which indicate the persistence of charisma in the church but are not specific to the pentecostal setting relate to: (i) the ongoing creativity in church culture as expressed in music and art; and (ii) the development of theology, forms of worship and formulation of ethical guidelines, all of which have retained the mystical element at the expense of the rational.
} 
a variety of ways such as an ability to: draw large crowds, impart faith, perform miracles, prophesy with profundity and precision, effect mass salvations or generally create a revolutionary atmosphere. Brian Tamaki would perhaps qualify as the movement's most recent practitioner to fit this description. Such a person is reminiscent of the founder, D. P. Williams, and both men demonstrate a variant expression of the charisma of Christ, the ultimate founder. While the functional sphere of Williams was international and Tamaki's is primarily national, it should be noted that personal bearers of charisma operate at several levels ranging from nation-wide all the way down to fellow members of a locally operating house-group. The depth of the charisma is commensurate with the level at which the individual is functioning.

Of course there must exist a body of people with a unity of purpose, i.e. a religious institution, within which the charismatic individual can perform. The bureaucratic machine must be working in order for charisma to be transmitted to succeeding generations. Weber's "iron cage," perhaps more accurately translated "shell hard as steel," 91 can be viewed as having one of two effects: either it extinguishes charisma, or it protects it, allowing the live force to be propagated. Specifically, the prophet's genuine charisma need not be so sharply contrasted with the priest's office charisma once it is recognised that individual prophets could not continue to emerge unless the religious life is maintained and cultivated by the priests; charismatic prophets presuppose the institution. $^{92}$

The body of Christ motif used by St Paul in Eph 4:12, juxtaposed to the list of ascension gifts, indicates strongly that the operation of charismata is here in view. In a similar way, Paul's list of charismatic gifts in I Cor 12:28 follows

\footnotetext{
${ }^{91}$ Max Weber, The Protestant Ethic and the Spirit of Capitalism, trans. Stephen Kalberg (Oxford: Roxbury, 2002).

${ }^{2}$ Stark used the word "presuppose" in reference to the Saints of the Roman Catholic Church emerging from the tradition. Stark, Sociology of Religion IV, 164.
} 
immediately on his statement that the individual readers are, in fact, members of the body of Christ. ${ }^{93}$ Paul's use of charismata is obviously a more narrow meaning than Weber's charisma, but it serves to show that Paul's expectation is that the communities of faith he is addressing would perpetuate Christ's activity through the use of spiritual gifts, so fulfilling the prediction that his followers would perform "greater works than these" (Jn 14:12) and therefore keep alive the same dynamic that first drew Christ's followers. Undoubtedly such activity would be abundant in supernatural, superhuman and exceptional powers characteristic of Weberian charisma. The Apostolic Church has, at various times in its short history, excelled in prophetic expression and subsequent apostolic enactment. Where the elected leader of the movement is charismatic, or fosters the charismata, there we see the ongoing effect of the collective charisma.

It seems, therefore, that Weber's theory correctly predicts a tendency within the church but does not adequately describe the totality of experience on account of three major factors: (i) the Christian's ongoing relationship with the living Christ, (ii) pneumatological expression, particularly prophecy, in the life of the church, and (iii) the phenomenon of the collective charisma.

\section{Conclusion}

The challenge for the Apostolic Church has been, and will no doubt continue to be, the exercise of prophetically guided government. We have outlined with numerous examples the deficiencies of "Divine government" but that does not negate the validity of this principle drawn from the New Testament. Clearly the frailties of human nature, most often expressed as personal agenda, jealousy and ambition, require constraint if they are not to

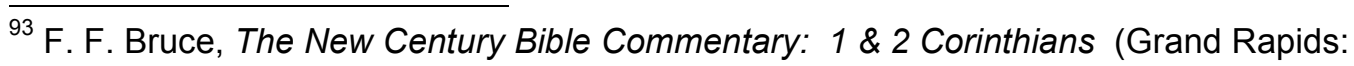


undermine the system. A frequent comment from older members of the Apostolic Church pastorate is that prophecy in the governmental setting functioned better when the prophet was not privy to discussions and, in fact, took no part in the deliberations which ensued. Cecil Scadden who served as an Apostolic Church Council member during the 1940s was most impressed when a prophet, absent from the daytime council sessions, would prophesy in detail concerning the day's proceedings, endorsing or adjusting the decisions where necessary. ${ }^{94}$

The Apostolic Church has followed a trajectory of reducing importance of prophecy. This has come about both by deliberate decision of the council and indirect consequences of various shifts in church practice and the spiritual climate. Consider the edict from the UK council to cease the practice of "enquiring of the Lord" in cases of divine healing ${ }^{95}$ and the decision of NZ councils to appoint local church officers without prophetic guidance. ${ }^{96}$ The involvement of prophets in the discussions at council has removed the potential for impartiality and confused their role. The emphasis on church growth, particularly through evangelism, saw the focus at the congregational level shift from exercise of spiritual gifts, of which prophecy was the most profiled, to promulgation of the gospel in various forms. These changes, coupled with the subjectively assessed downturn in the quality of prophetic utterance, has reduced the impact of prophecy. Currently, as we have seen, government of the church is consultative, with prophecy in the main performing an ancillary role. However, this is not altogether unexpected or unreasonable. The

\footnotetext{
Eerdmans, 1971), 122.

${ }^{94}$ Cecily Worsfold recalls her father, Cecil Scadden, expressing this sentiment when she was a teenager. C. M. Worsfold to Luke Worsfold, 20 November 2003.

95 See above, Chapter Four, "Prophecy," 150.

96 See above, Chapter Four, "Prophecy," 152

Consulting the Lord for guidance on matters which may now be considered appropriate for a free-willed individual to decide was prevalent amongst the early members of the Apostolic Church. Marjorie Blick, member of the Wellington congregation in the 1930 s sent to Britain to
} 
Apostolic Church has shifted significantly in its understanding of the nature of prophecy from the infallible "word of the Lord" in the time of the Williams brothers to the "divine-human mix" expressed in the present day.

It is unlikely that the ineptitude and abuse which the prophetically-driven centralised government engendered in the New Zealand Apostolic Church could ever be repeated, given the current structure. On the other hand, the depth of prophecy evident in the early years of the New Zealand church has yet to be recaptured. It is no longer appropriate for a movement to be influenced by centralised prophetic input; however, there exists a definite role for the development of prophecy for the express purpose of guidance in the local church and strategic planning at the regional level. The dilemma for the Apostolic Church is the lack of uniformity and unity if an avenue of revelation, presumed applicable to all congregations, is removed. Certainly the early Apostolic Church pulsated with a common vision and this brought considerable benefit. However, with growth of the movement and a decentralised government, individual assemblies have developed an ethos requiring specific prophetic input. Prophecy delivered at the national level has been unable to fulfill this need, which has indirectly prompted attempts to restructure the movement. The organizational structure of the denomination has been the subject of much attention, particularly since 1997 , so at this point we direct our assessment to the ecclesiology of the Apostolic Church.

"enquire of the Lord" concerning the name of her first-born. The answer duly arrived and he was named Samuel. Cecily M. Worsfold to Luke Worsfold, 2 January 2004. 


\section{CHAPTER SIX}

\section{CHURCH ORDER}

The ecclesiology of the Apostolic Church can be adequately described by the phrase 'divine government through the restoration of apostles and prophets.' It is the revelation via the prophet for guidance in administration of the church which distinguishes the Apostolic Church from other pentecostal groups. Response to the prophetic which affects the affairs of men necessitates that a quality utterance be achieved and this ability is concentrated into a relatively small group of men. Government, therefore, operated centrally: it was not possible to direct a growing movement which relied on prophetic guidance by having revelatory voices operating at numerous points around the country. Administration of resources was also a necessary function of this central voice, not only supplying the wherewithal, but helping to keep the unity, even the uniformity, of the mission. Centralism, then, is a hall-mark of divine government and is characterised predominantly by a head office administration of personnel and finance. ${ }^{1}$

\section{Finance}

Centralism meant that even minor decisions relating to the church property required permission from an area meeting of apostles and pastors. Detail was no barrier to discussion: the 1965 request by the Palmerston North assembly

\footnotetext{
${ }^{1}$ The catalyst for the Welsh secession relates to the centralisation of finance. If the genesis of the Apostolic Church had not been hidden, the same mistakes may not have occurred 50 years later in New Zealand in reaction to the centralisation of finances; the third generation ministers in New Zealand laboured under the misconception that the movement arose directly from the
} 
for a gate was agreed to, the pastor being asked to "submit estimates for a suitable type of gate." ${ }^{2}$ The same area meeting later that year authorised repairs to the Napier manse stove. ${ }^{3}$

Of greater ramification was the central government's redirection of funds. The Maori Mission Advisory Panel raised the question of the national executive as to the whereabouts of the Taumarunui building fund which had failed to appear on finance statements for a period. The money had been accumulated via a nation-wide appeal for the purpose but "the decision was made that this fund be used for other essential requirements such as the Otorohanga church, which is now freehold." The executive minute then attempts to reassure the enquirers that financial help will be available when required; however, the reassurance is embedded amongst qualifiers. Not only Taumarunui, but "any other centre" was identified as recipients of any future assistance which, incidentally, would be in addition to the contributions of the local church. Further, the situation would have to be one that "merits action," the example given of an assembly which had acquired land and was ready to build. ${ }^{4}$ The difficulty with this procedure is that individuals had responded to the appeal for funds on the understanding that it was for a designated purpose, so for the monies to be reassigned without consultation or feed-back shows disregard for the contributors. The approach taken by the executive highlights the deficiency of a highly centralised system: the main concern was to collect funds, not keep the contributors in the picture. Two years later the executive were able to address the situation in a less defensive manner. The minute simply read:

THAT we bear in mind the fact that the money previously designated for a building in Taumarunui was transferred, and used in the purchase of the

Welsh Revival as a sovereign work of the Lord and therefore its system of government and associated practices were inspired. See Chapter One above, "Apostolic Church Origins."

${ }_{2}^{2}$ Minute 7, Central Area Apostles and Pastors meeting minutes, Fielding, 9 March 1965.

${ }^{3}$ Minute 8d, Central Area Apostles and Pastors meeting minutes, Fielding, 6 September 1965.

${ }^{4}$ Minute 5a, Executive minutes, Auckland, 29 October 1965. 
Otorohanga church. Should an interest and need arise in Taumarunui, due consideration would be given to this. ${ }^{5}$

Centralism required that all tithe collected in the various assemblies be sent to the national office, as were the proceeds from locally operated bookshops. All orders for stock were handled centrally, no local bookshop being allowed to order direct from the publisher. ${ }^{6}$ This system of operation generated a satellite mentality amongst the congregations while at the same time engendering a strong sense of unity. Unfortunately, centralised government has the potential to prioritise its own administrative functions at the expense of those it serves. An example of such unilateral interests in administration is well demonstrated by the occasion when the executive, in an effort to reduce administrative costs, decided to discontinue posting out from the national office the master monthly plan of all speakers in every assembly, while still requiring the individual assemblies to send in their ministry plans. ${ }^{7}$ Many pastors felt a life-line had been severed, one writing in the margin of his copy of the minutes that it "breaks down essential Apostolic family fellowship - get more staff." ${ }^{8}$ So too did the central area apostles and pastors worry about isolationism, stating that the plans served as a "source of inspiration and information." Here, head office had made a requirement of local assemblies but had removed the reciprocal benefit. In defense of centralism it could be argued that the individual pastors would indirectly benefit from the cost-cutting exercise. Of cardinal importance in this instance is the perspective from which the decision is viewed: for head office it is pragmatic, for the local pastor it is relational.

\footnotetext{
${ }^{5}$ Minute 19, Executive minutes, Hamilton, 6-7 December 1967.

${ }_{7}^{6}$ Minute 29, Council minutes, Wellington, 30 March - 2 April 9 \& 12 April 1966.

${ }^{7}$ Minute 15, Executive minutes, Wellington, 27-28 July \& 2 August 1971.

${ }^{8}$ Rex Meehan, personal notes on Executive meeting, Wellington, 27-28 July \& 2 August 1971.

9 Minute 11, Central Area Apostles and Pastors Meeting minutes, Palmerston North, 28 September 1971.
} 
The notion of financial consolidation for the benefit of all contributors was challenged when it began to retard the progress of successful congregations. In 1967 the Dunedin presbytery put forward a remit at the southern area apostles and pastors meeting to the effect that it take more responsibility in administering some of the local property finances which were then the purview of the national council. The Dunedin assembly had purchased a tenanted twostorey house adjacent to the church and were requesting permission to retain the rent to enable the presbytery to utilise it directly. Such an arrangement, they posited, would relieve the difficulties of "long-range administration" while, at the same time, develop local acumen. ${ }^{10}$ The national executive were totally unable to cope with such a departure from centralism, managing only to reiterate the policy line "that the Finance Board is the recognised body looking after the financial interests of the whole Church." In the relevant minute the executive stated, in what can only be considered a condescending fashion, that they were "assured that . . s something can be arranged" so that Dunedin could "act in an advisory capacity in letting." The message to the presbytery was a loud one: the control of finances was indisputably central. The challenge to the doctrine of centralism was met with a particularly forceful response to the extent that the local presbytery's authority, even in routine matters, was diminished, Dunedin being made well aware that even the decision as to who becomes a tenant in a church property belongs to the central government. The point was driven home even more deliberately with the remainder of the minute: besides possible input into the choice of tenant, Dunedin were invited to inform national office of maintenance needs and there was the directive that money received from the property be paid to Wellington via the tithe sheet. The executive naïvely believed that such an arrangement would not be detrimental to the local

\footnotetext{
10 Minute 7a, Southern Area Apostles and Pastors Meeting minutes, Dunedin, 2-3 June 1967.
} 
enthusiasm but, rather, effect a "common bond of unity and fellowship." The rationale for strong adherence to centralism, as expressed in the minute, is that the benefit is "not only to any one assembly, but to the whole Church."11 At the time, Dunedin was the largest assembly in the country and was the second highest financial contributor: it is not difficult to understand why the executive should be so energetic in defending, indeed promoting, the central collection of locally derived money.

The response of the executive to the Dunedin presbytery was evidently not received with much enthusiasm by the latter group, judging by the record of events as they appear in council minutes of the following year. The council aired their appreciation for the work of the Dunedin presbytery in procuring the house and, to register their sentiment, allowed the presbytery to continue with management and development of the property. Further, council recognised the desire of the presbytery to relieve the central church government and, somewhat meekly, asked Dunedin to work "in conjunction" with the finance board and executive. ${ }^{12}$ This concession signaled a departure from the rigidity of centralism and laid the groundwork for later changes in releasing autonomy, not only to the region but to the local assembly as well.

The finance board were not oblivious to the inequities of the common purse but rather than promote autonomy it drew attention to the need for assemblies to be self-supporting. The 1971 report from the finance secretary noted that eight assemblies were more than self-supporting, thereby creating a surplus, and that a further 12 assemblies were not. The report posed the question as to how the movement could expand given that 12 assemblies were being subsidised by eight. ${ }^{13}$ The following year the finance board proposed concessions to local congregations to enable them to retain for "approved local

\footnotetext{
${ }^{11}$ Minute 8, Executive minutes, Wellington, 31 October \& 4 November 1967.
} 
development" any surplus over its board-specified target, which was to reflect the national budget. ${ }^{14}$ Evidently the executive viewed the proposals as advocating "stronger centralised control" and penalising non self-supporting assemblies, prompting the finance board to deny these assertions in a later meeting and present revamped suggestions. Although not entirely clear, it is likely that the proposals looked to be giving additional sponsorship to centralism by dividing up the national budget to arrive at the local target figures rather than identifying local costs specific to each assembly. The re-worked proposals included allocating $20 \%$ of surplus over a board-set budget (set to reflect actual needs) back to the assembly and placing the responsibility for maintenance costs with the local church via the "local development fund." In addition, churches that were not self-supporting would be given a grant-in-aid with additional grants for outreach possible on submission to the board. ${ }^{15}$

While the drive for assemblies to be self-supporting continued, bolstered from time to time by the finance secretary, the situation remained where the national tithe pool was being drained by those assemblies with insufficient income. In 1977 the national finances were such that there was a moratorium on appointment of pastors to salaried positions. In a statement that echoed some of the sentiments previously vocalised, the finance advisory board said: "We are in a financial straightjacket with the weaker assemblies using the surplus funds and until there is a considerable reversal of this problem, we cannot recommend the release of another man into full time work."16 The resolution of this concern would come in the form of financially autonomous assemblies. Up to this point, only local responsibility for maintenance had been

\footnotetext{
${ }_{12}$ Minute 31a, Council minutes, Wellington, 2-8 \& 16 April 1968.

${ }_{13}^{13}$ Appendix to Finance Board minutes, Wellington, 12 October 1971.

14 Minute 7, Finance Board minutes, Wellington, 28 September 1972.

${ }^{15}$ Minute 3 \& appendix, Finance Board minutes, Wellington, 24 July 1973.

${ }^{16}$ Minute 4, Finance Advisory Board minutes, Te Nikau, 29-30 July 1977.
} 
a priority; local administration of finances did not commence until $1^{\text {st }}$ March, 1980. $^{17}$

An obvious corollary of local financial autonomy is the ability of a congregation to provide the resources before undertaking new responsibilities. The Executive of the Apostolic Church in Great Britain was alarmed that decentralisation was taking place in New Zealand, particularly the notion of appointing pastors only "when local assembly funds are sufficient to support him." The British found such moves to be "contrary to Apostolic conviction and practice" and were mystified as to why changes should have been made to the longstanding "proven path."18

While the central tithe pool was replaced with local responsibility, the requirement for national administration funding remained, hence the institution of the levy. The levy was introduced as a tithe on the tithe; in other words $10 \%$ of the congregation's tithe was levied to national office. For those pastors with self-supporting congregations who had laboured under the centralised finance scheme, a percentage contribution to national office was a significantly more appealing arrangement. Yet, for the newer pastors who had never known the former days of central control, even the levy became irksome. This was particularly so for sizeable churches with the accompanying large income. Contributions to national office were considered a "strong moral obligation" and could only be suspended with prior consultation. If an assembly was in financial difficulty, the levy, normally set at $10 \%$, could be reduced to $5 \%$ for six months at which time a decision may be made to defer payment and accumulate as a debt to national office. ${ }^{19}$

\footnotetext{
${ }_{17}^{17}$ Minute 9, Council minutes, 9-12 September 1980.

${ }^{18}$ A. J. Rees, general secretary UK Apostolic Church, letter to Ron Goulton, general secretary Apostolic Church NZ, 22 June 1981.

${ }^{19}$ Minute 12c, Executive minutes, Te Nikau, 4-5 November 1986.
} 
The secession of Brian Tamaki's Lake City Church from the Apostolic denomination in March 1994 was as much a reaction to the $10 \%$ financial levy to national office as it was about the movement's supervisory structure. Reasons for the departure, listed in Tamaki's one-page document for the national council, fell into two categories: (i) the precedence of relational networks over denominational ones and (ii) financial autonomy. Under the latter heading the priority claim of Lake City over their own income was clearly stated and, for the movement in general, a needed change "from the principle of remittance, to a philosophy of "user pays."' That the national levy was bothersome to Tamaki is reflected in his statement to the executive that he could make better use of $\$ 40,000$ in church planting than sending it to national office $^{20}$ and in his question posed to the council several weeks later, "what is our remittance being used for?"21 Lake City was, at the time, the second largest congregation in the movement numbering over 650 and would therefore have had a significant income, none of which Tamaki wanted to release to endeavours that did not fit into his vision. The council was apparently unable to adopt a quick shift in thinking, instead suggesting more consultation and a series of meetings around the country with the aim of bringing definite proposals before the council within four months. Tamaki's response was that if the council could not accommodate Lake City then they would secede as planned. Tamaki was resolute in his stand, drawing confirmation for his action directly from God. In this he was, perhaps unwittingly, employing against the council their own practice of appealing to divine revelation to authenticate their decision and place it above question. However, Tamaki's appeal to the divine leading was not accepted by the council. After he had left the meeting there were some

\footnotetext{
${ }^{20}$ Rex Meehan, informal report of Executive members meeting with Brian Tamaki, Rotorua, 22 March 1994.

${ }^{21}$ Rex Meehan, handwritten notes of Council meeting, Waikanae, 7 April 1994.
} 
strong expressions that he was doing the wrong thing: Ray White pronounced that Tamaki was "producing an Ishmael" and that the issue was "not all over."22

It is not coincidental that several months later Bruce Monk and his elders at Auckland City Church requested the executive to register the Mercury Theatre, as proposed church property, in the name of the locally administered Network Ministries Trust rather than the Apostolic Trust Board. Citing the need for administrative autonomy in order to grow a strong local church, the Auckland City Church leadership recognised the innovative nature of such a move yet urged the executive to continue the trend toward decentralisation. ${ }^{23}$ At the time of the Lake City Church secession Monk believed that, while Tamaki should not go, God was using the situation to catalyse the Apostolic Church to restructure. ${ }^{24}$ This incident undoubtedly set the scene for Monk to make his approach to the national church government. Obviously aware that the council would be twitchy and still smarting over the Lake City affair, Monk stated in his letter that "our desire is to remain part of the Apostolic Church" and that the request for administrative change was not to facilitate secession. ${ }^{25}$ This robust talk was met with equally strong sentiment from the executive in reply, a summary of the salient points being:

i. Such a change in policy would require a constitutional amendment which the executive has no power to make but would require nation-wide circulation for discussion prior to tabling at council.

ii. The question of church ownership was canvassed at the last council with the result being endorsement of Trust Board ownership, so while the topic could be raised at the next council, any proposed change would have little chance of acceptance.

\footnotetext{
${ }^{22}$ Meehan, handwritten notes, 7 April 1994.

${ }^{23}$ Bruce Monk and Ross Forsyth, letter to Executive, 7 July 1994.

${ }^{24}$ Rex Meehan, handwritten notes of Council meeting, Waikanae, 7 April 1994.

${ }^{25}$ Monk and Forsyth, letter, 7 July 1994.
} 
iii. The Trust Board is only likely to act against the decision of a local presbytery where the congregation has seceded or is in serious debt.

iv. No local church can lay exclusive claim to an asset, rather, it belongs to the church of the past, present and future. ${ }^{26}$

All properties are held by the Trust Board, but there is little influence from the Board in terms of acquiring or disposing of buildings, plant or land. The national levy is still in place but it decreased from 10 percent to $71 / 2$ percent in 1997 and has subsequently been reduced further to $5 \%$. No assembly is exempt, although it appears that the church pastored by national leader Bruce Monk, "London Equippers Church," has only recently begun contributing to the New Zealand purse. ${ }^{27}$

\section{Centralism's Other Arm}

If national control of finance was one distinguishing feature of centralism the other was council-directed relocations of personnel to different pastorates around the country. This, more than any other activity, had the greatest potential for misuse and destroying the progress of both man and the movement. Quadrennial council meetings, held before the annual national convention in Wellington, decided pastoral changes with the benefit of prophetic input. The usual practice was for prophecy to confirm a change; however, on occasion the prophetic voice overturned a decision. ${ }^{28}$ Not every relocation decision was arrived at with the assistance of prophecy but the pastors affected by the change were not necessarily privy to the decision-making process in their particular case, and the council ruling was considered to be without recourse so the proposals were effected dutifully.

\footnotetext{
${ }^{26}$ Minute 15b, Executive minutes, Waikanae, 15-17 August 1994.

${ }^{27}$ Manu Pohio, phone interview with Luke Worsfold, 22 April 2003.

${ }^{28}$ Worsfold, Origins, 281.
} 
Appointment to the ministry in the first place was a function of central government. Any prospective candidate was interviewed by two members of the council or executive, wherever possible this being the president and general secretary, with an invitation to the local pastor to be present. This procedure had obviously not been followed at some point circa 1969 because a minute appeared in the executive minutes that year reminding readers of the established protocol. ${ }^{29}$

The council was pragmatic in its operation: it would intervene and simply relieve a man of his pastorate if it felt that his health was failing or that the assembly was not maintaining well. For example in 1966, the council decided that P. Kihirini, who was responsible for Waitangi, Te Puke, should be relieved of his assembly because of his health and two pastors were assigned to interview him and convey the council's decision, after which council appointed his successor. $^{30}$

At the council meetings in 1968 it was decided that Mark Goulton should become the president of the movement. This was a curious decision considering his pastorate, Wellington, was failing markedly. It is therefore not surprising that Goulton was released from the responsibility of a congregation, the stated reason, however, being to "bring a greater impact and spiritual leadership" to the movement nation-wide. ${ }^{31}$ In his earlier role as national secretary Goulton had requested that an extra pastor be appointed to the congregation even though attendance at the time (1965) was averaging 45 on Sunday mornings; this subsequently dropped to 36 by August 1967 . $^{32}$ At the central area apostles and prophets meeting in 1967 the need for a "full-time pastor or co-pastor" was expressed citing Goulton's national duties for the lack

\footnotetext{
${ }^{29}$ Minute 5g, Executive minutes, Auckland, 28-31 October 1969.

${ }^{30}$ Minute 31g, Council minutes, Wellington, 30 March - 2 April 9 \& 12 April 1966.

${ }^{31}$ Minute 11a, Council minutes, Wellington, 2-8 April 1968.

${ }^{32}$ Apostolic statistics, 1965 \& Council minutes, 1967.
} 
of growth of the Wellington assembly - "Wellington can hardly expect to increase when it only has part of a Pastor's time." ${ }^{33}$ However, the precedent had always been for national office holders to have the responsibility of a congregation. Goulton was a successful evangelist and could stir enthusiasm on almost any topic but was simply not tailored to be a local pastor. Goulton's evangelistic ability did not translate to numerical growth in the Apostolic Church during his presidency; his review of the movement given at the 1972 council noted that the statistics were "a little disappointing" although he had confidence that the following year would show an increase. ${ }^{34}$ The Apostolic Church had here confused evangelistic ability with leadership prowess and succumbed to the temptation to promote an individual talented in the public arena as a visionary and developer of the movement.

A significant point of influence on the decision to appoint Goulton as president must have been an eight month tour of Europe, the East and the USA he had taken the previous year which had reportedly been a great success. ${ }^{35}$ It is apparent from council minutes of 1968 that prophecy did not direct the choice of president, rather, the prophets spoke to confirm the action after the fact. At the same council, W. W. Pearson was elected as vice president and J. E. Worsfold as national secretary, positions which roughly equated to second and third in command respectively. ${ }^{36}$ It was planned that Pearson would move from Auckland to Christchurch and Worsfold from Dunedin to Wellington. ${ }^{37}$ Both Dunedin and Auckland were successful assemblies, ranking first and second in the nation respectively, so with the headquarters church attendance languishing

\footnotetext{
${ }^{33}$ Minute 17, Central Area Apostles and Pastors meeting, Fielding, 28 February 1966.

${ }^{34}$ Minute 6, Council minutes, Wellington, 29 February \& 1-2 March 1972.

${ }^{35}$ The comprehensive overseas trip taken in 1967, mainly to represent NZ at the Apostolic Church UK general Council, incorporated his annual holidays. The minute reads that Goulton chose to take his holidays from the time the journey started so giving him "a little extra time in order to give ministry" at various places. Minute 12e, Council minutes, Wellington, 14-17 February 1967.

${ }^{36}$ Minute 11a, Council minutes, Wellington, 2-8 \& 16 April 1968.
} 
in the thirties it is not difficult to see the reasoning behind moving a pastor with proven church-growth ability to rebuild what was once the movement's flagship congregation. ${ }^{38}$ Worsfold was unwilling to go but having spent 12 years in the southern pastorate he was well overdue for a relocation given that the average term a pastor could expect at that time was four years. A possible alternative would have been Pearson; however, the national secretary needed to operate from headquarters and locating the vice-president in the South Island spread the availability of the senior apostolate a little more evenly. Neither the Auckland nor Dunedin pastor's moves were decided on the basis of prophecy but, as in the case of the president's election, the prophet endorsed the decisions made by council. ${ }^{39}$

Equally devastating on pastor and congregation alike was the forced removal of J. W. Keane from Rotorua. In 1971 he took long-service leave and planned to be away from his assembly for approximately six months and requested the executive to provide a short-term replacement. The executive, however, reasoned that Keane would be nominated for a relocation at the quadrennial council the following year and so it would be expedient to have him vacate the pastorate early and have a permanent replacement installed.

37 These relocations were two out of a total of 13 decided on at this Council. Minute $11 \mathrm{r}$, Council minutes, Wellington, 2-8 \& 16 April 1968.

${ }^{38}$ In 1965 only three assemblies had 100 or more people in attendance on a Sunday, i.e., Auckland, Rotorua, Dunedin. Apostolic Church Statistics, 1965 in Council Minutes, Easter 1966.

The largest church in 1966 was Dunedin, i.e., members + adherents $=115$. Apostolic Church Statistics, 1966.

The largest church in 1967 was Dunedin, i.e., members + adherents $=130$. It was one of two assemblies which had Sunday attendances over 100, Dunedin attracting 110 at night the other being Gisborne with 120 at night. Apostolic Church Statistics, 1967.

${ }_{39}$ E. J. R. Belcher replaced Worsfold in Dunedin and A. V. Arnold replaced Pearson in Auckland. L. J. Derry prophesied confirmation of all the moves after they had been decided, the following statement being representative of his utterance: "It is indeed my will for my servant Belcher that he shall go even as you have decided, to Dunedin."

Endorsement of Goulton as president had earlier come through the prophecy of Peter Galletly, a lay pastor who was to become a full-time salaried staff member in December that year so it was beholden on Derry, the senior prophet, to provide some weight to the prophetic ratification. This he did in rather unconvincing fashion with the following words: "For I have already given unto you confirmation with regard to your choice of a president. I will confirm this again, for my hand is in this, and I would indeed say unto you that no man hath need to fear the future when 
Oblivious to the arbitrary and damaging nature of this decision, the executive readily offered to provide storage, at their expense, for Keane's personal effects while he was away. In what is a sure indicator of the executive's confidence in the finality of their own decisions, the minute continued with a record of appreciation of the Keanes' efforts during their term in the Rotorua assembly. ${ }^{40}$ Keane's assessment of the proposed move did not accord with the executive's.

Prophecy was absent from the deliberations of the executive, however, $\mathrm{W}$.

I. Frater prophesied at council the following year that new doors would be opening to Keane and that as he was going overseas the Lord wanted him to be free from burdens. The word also promised that Keane would be coming into contact with "influential men and people in high places" through which he would experience an increase in his ministry. The senior prophet, L. J. Derry, brought a more dictatorial note to the situation: he prophesied "it is indeed my will " for Keane to relocate from Rotorua to Otara, the place designated for him by the council. Reinforcing the fundamental concept of divine government Derry continued:

It is important that every man should move in my purpose. Again I challenge you all concerning your own location, for no man can claim a location for himself, for I will plant you, I will uproot, and I will direct for I indicate the need of speed in some of the moves which involve you, my servants. It is true that the enemy will seek to pull down and oppose that which I seek to build. ${ }^{41}$

Keane demonstrated ownership of the work in Rotorua, the prophet labelling such devotion as claiming a location. Derry, himself not a successful pastor, was quite happy to comply with regular relocations at the behest of the council and presumably could not sympathise with Keane's stand. The

his life is in my hands." Lewis Derry, transcript of prophecy, Council minutes, Wellington, 2-8 \& 16 April 1968.

${ }^{40}$ Minute 19, Executive minutes, Wellington, 9-12 November 1970. It is interesting to note that the Executive cited the potential for a temporary replacement to be "an expensive arrangement." It was an extremely short-sighted and materialistic view and, as it transpired, a particularly disastrous one. Rotorua was at the time displaying the largest attendances in the 
attribution of desire to remain in a pastorate to the devil's work is a gross misunderstanding of the pastoral heart of a minister. ${ }^{42}$

Neither the executive decision nor the prophet's words held sway with Keane who continued to object to the move; however, in a meeting that preceded the 1971 council, the executive indicated that their decision was right and would be beneficial for the Apostolic Church, not only in Rotorua, but nation-wide. ${ }^{43}$ It seems that at some point Keane gave in to the demands of the council and agreed to the move. However, on his return from long-service leave spent overseas Keane addressed the executive explaining that personal conviction prevented his removing to Otara. The executive stood firm, the minutes reflecting the mood of the meeting in that he "should abide by the council's decision which was confirmed by prophetic ministry." Later in the proceedings, during a second discussion, Keane relented and agreed to remove to Otara, much to the relief of the executive. ${ }^{44}$ The self-assessed rightness of the executive and equating of their decisions with the will of God is well summarised by the words of $\mathrm{B}$. R. Kirton, a new prophet at the national level, who said:

I will remove the conflict that has surrounded my servant Keane and I will cause a divine perspective to be shed abroad in his heart and life and I will cause that he move in my will and purpose and he shall find in me a fresh revelation, a fresh vision and a fresh inspiration that shall be in line with my purpose for the whole of my church.

\footnotetext{
country and was the fifth largest financial contributor. The replacement, H. J. Robinson, did not have a successful ministry and the assembly struggled for years to regain its strength.

${ }^{41}$ Lewis Derry, transcript of prophecy, Council minutes, Wellington, 2-4 March 1971.

42 Keane's commitment is representative of the devotion which veteran pastor Jack Hayford says is characteristic of true pastors: that is, those who are "charged with a divinely assigned high responsibility to lead" and are called to rescue and serve deep need, a concept which he summarises as a life of service, faith and self-giving. Jack W. Hayford, Pastors of Promise: Pointing to Character and Hope as the Keys to Fruitful Shepherding (Ventura: Regal Books, 1997), 9, 24. This notion is drawn from the biblical analogy of the shepherd who lays down his life for the sheep, as opposed to the hireling who has a lower level of commitment (Jn 10: 1113).

${ }^{43}$ Minute 5, Executive minutes, Wellington, 1 March 1971.

${ }^{44}$ The minute records: "Finally the meeting was relieved and grateful to hear [sic] that he would be prepared to go to Otara as previously agreed." Minute 5, Executive minutes, Auckland, 2628 October 1971.

${ }^{45}$ Brian Kirton, transcript of prophecy, Executive minutes, Auckland, 26-28 October 1971.
} 
The stance of the prophet in the episode with Keane highlights an interesting point: all the prophets at the national council over the years 19651990 did not find it easy to fulfill the expectations associated with pastoring. ${ }^{46}$ The exception to this is Blair Dickie; however, he was not the archetypal prophet. He never provided specific direction in his prophecies, a fact that prompted him to question his suitability for contributing to council meetings. At that time he also questioned receiving revelation through the prophetic mode and suggested appraising the administrative system in this regard. ${ }^{47}$ It has long been argued that the demeanour of a prophet is contrary to the heart of a pastor so it is unrealistic to assume the two functions can coexist in the one individual. However, the Apostolic Church did not envisage the office of prophet being fulfilled without that individual also functioning as a pastor given the understanding of the time that an ascension gift office-holder ${ }^{48}$ could be nothing less than a "called-out man," that is, a full-time church employee.

The 1972 council saw the re-election of Goulton, Pearson and Worsfold in the positions of president, vice-president and general secretary respectively with Goulton continuing to be free from the responsibility of a local assembly. ${ }^{49}$ These re-elections appear to have not been at the direction of the prophet, but L. J. Derry duly supplied the confirmation which had become standard after such decisions. In all three cases he prophesied along the lines that the anointing of the Lord would continue to rest upon them. ${ }^{50}$

\footnotetext{
${ }^{46}$ It was the standard expectation for a congregation to be "built up" as a result of a change in pastor. The usual four year period of posting was considered sufficient time for an individual's leadership skills to be evidenced in the bolstering of a congregation's attendance figures and level of activity. Most pastors were able to at least maintain the new congregations to which they were sent, but for the prophets of this period the common result seemed to be decline in attendance and general level of enthusiasm.

${ }^{47}$ Blair Dickie, letter to general secretary, 30 September 1980.

${ }^{48}$ Eph 4:11 refers to the gifts of apostle, prophet, pastor, teacher and evangelist given by the ascended Christ to the church, hence the designation "ascension gifts."

${ }^{49}$ Minutes 15 \& 19, Council minutes, Wellington, 29 February \& 1-2 March 1972.

${ }^{50}$ Lewis Derry, transcript of prophecy, Council minutes, Wellington, 29 February \& 1-2 March 1972.
} 
The transfer of L. J. Derry to Papua New Guinea in July 1975 elevated W. I. Frater to the position of senior prophet for New Zealand. The decision concerning the relocation had been made the previous year, so it was quite probable that by May of 1975 Frater was feeling the weight and urgency of his new responsibility such that he was prompted to prophesy changes in the senior offices at an executive meeting ahead of the quadrennial council scheduled for 1976 . The executive minutes record that prophecy came, which would be referred to the council. Frater prophesied to Goulton: "I am releasing you from the presidency of this council, this year and not another year." He then identified Pearson as the president of the council and Belcher was told he was being sent to California in the near future. At the quadrennial council in 1976 no additional prophecy was recorded which nominated or released individuals to office, yet the minutes state that the September 1975 council:

Accepted the prophetical ministry concerning the office of:

President: We now appoint Pastor W. W. Pearson as president of the council.

Vice-President: Pastor E. J. R. Belcher.

General Secretary: Pastor R. M. Goulton. ${ }^{51}$

The misrepresentation in the minutes is most likely the result of a desire to authenticate the appointments of vice-president and general secretary to the level that the nomination to president enjoyed. Belcher was a quiet, nonconfrontational follower who would have provided no opposition to the notion of Ron Goulton receiving an executive position. For Belcher it was a dead-end appointment; there was no hint that he would ever be the president of the council. $^{52}$ The appointment of Ron Goulton as general secretary, an administrator with no pastoral experience, to a position of spiritual authority in the movement was a deviation from the norm. At an extraordinary meeting of

\footnotetext{
${ }^{51}$ Minute 10, Council minutes, Wellington, 16-19 March 1976.

52 Belcher later moved to Seattle taking up a position with the Pentecostal Holiness Church so James Worsfold was made vice-president in his place. Minute 10b, Council minutes, Te Nikau,
} 
the council in October 1974, Lewis Derry prophesied concerning Ron Goulton that "the mantle of apostleship rests upon him." W3 While it was not unusual for prophets to suggest the future direction for an individual, the resulting pathway of Goulton was unprecedented. Less than two weeks later, at another council meeting in Wellington, the prophetic identification of Goulton as an apostle was ratified, the minutes recording that his call be in the realm of administration but "without pastoral responsibility." At the time he was working as an accountant and involved in the Wellington assembly as a presbyter as well as functioning as the secretary to both the national finance and missionary boards. However, during the council meetings Ron had telephoned his father to advise that his job as an accountant had terminated. This news was interpreted by his father as a sign that Ron should be employed by the church, hence the minutes record that "in the light of our brothers [sic] present circumstances" the council consider a salaried position for him. Within a month Ron Goulton was appointed to the fulltime salaried staff. It was decided that Ron Goulton would be ordained to the apostleship on the Sunday morning of the National Easter Convention in Wellington the following year, and that he would receive the courtesy title of "Pastor." "55

Catapulted into the world of church government as an apostle, albeit one without spiritual authority, with the aid of the title "Pastor," the effect was a smooth transition from father, as president, to son, as general secretary. The national office was immediately moved to the Apostolic Church Training Centre, "Te Nikau," in Paraparaumu, where Ron Goulton was allocated to teach "Leadership and administration" to the students in the newly-formed ministry

28 August-1 September 1978. This move from the Council was perhaps compensatory, bestowing a promotion on one who had endured a previously unpalatable council decision.

${ }_{53}$ Lewis Derry, transcript of prophecy, Extraordinary Council minutes, Wellington, 29-31 October 1974.

${ }_{54}^{5}$ Minute 30b, Representative Council minutes, Wellington, 12-14 November 1974.

${ }^{55}$ Minutes 5a \& 5d, Executive minutes, Wellington, 24 March 1975. 
development course. ${ }^{56}$ Administration-wise, there was none more qualified to teach than Goulton, particularly with his long involvement in the functioning of the Apostolic Church, but he was totally unproven in the area of leadership, having only ever been an elder in his father's small congregation.

Pearson was convinced that to hold the office of president he needed to be in the capital; not only that, he required the Wellington pastorate, Charisma Chapel, which at that time was held by the outgoing general secretary, Worsfold. The account of this relocation fills yet another chapter in the 'abuses of centralism' story. The prophets were silent on the issue of the president's location and the minutes do not reveal how Pearson's personal wish was granted; however, it is known that the incumbent protested the notion of losing his pastorate and being sent to Auckland. At the time of the council the Auckland pastorate was vacant due to A. V. Arnold having taken up missionary responsibilities in Papua New Guinea at the beginning of 1976 . The Christchurch scene was a different matter. Pearson had been successful there, reporting the largest average Sunday morning attendance in the country for 1975, and so a suitable replacement had to be found. Rex Meehan, from Hastings, was the one chosen; however, he did not want to go. He outlined to the president and general secretary, who were commissioned by the council to interview him, his commitment to the Hastings congregation and to the outworking of forward plans which were based on prophecies from Derry and Frater, the movement's two senior prophets. Meehan conveyed the need for continuity, and concern that the pastor nominated to succeed him would not deliver same. The strongest argument against relocating offered by Meehan was that he felt absolutely no conviction to move to Christchurch at that time,

\footnotetext{
${ }^{56}$ Minute 11, Bible Training Committee minutes, 30 April \& 28 June 1976. For the remainder of this chapter where "Goulton" appears it will refer to Ron Goulton.
} 
although he envisaged such a move in the future. ${ }^{57}$ Meehan acceded to the council's request and duly moved to Christchurch. This produced negative results in Hastings and Christchurch: both assemblies suffered great losses in membership and took years to recover.

The Wellington presbytery reacted to the news that their congregation was to lose its pastor and lodged a submission with the central area apostles' and pastors' meeting. This body in turn forwarded a remit to the executive that it urgently reconsider the planned relocation. The executive referred the matter to the council who discussed the application but remained steadfast in their opinion that Worsfold was "required in Auckland as soon as possible." It is interesting that, according to the minutes, prayer was offered for Worsfold to "feel a release and peace" about the situation rather than prayer for guidance in re-evaluating the council decision in the light of the pastor's convictions. ${ }^{58}$ During that meeting Meehan, who was the object of the related forced move, made notes in which he observed that for the council's part, the right decision for progress and development was for Worsfold to go to Auckland. He then asks himself, "But is it right to make decisions exclusively for the progress of the church movement? Is there a place for considering the will of God for the man - and his personal fulfillment?"59

The resolute stand by the church government prompted Worsfold to make a "last ditch" personal appeal to the council on compassionate grounds, the basis being that the proposed relocation coincided with his youngest child entering the final year of secondary school. Council responded by restating its opinion and making the concession that should Worsfold be "unable to respond"

\footnotetext{
${ }^{57}$ Report of interviews by Pastors M. Goulton \& J. E. Worsfold (president and general secretary respectively), Wellington, 22 March 1976 in fulfillment of minute 20, Council minutes, Wellington, 16-19 March 1976.

${ }_{58}$ Minute 7b, Council minutes, Te Nikau, 21-23 July 1976.

${ }^{59} \operatorname{Rex}$ N. Meehan, handwritten notes on his copy of the annual Council agenda, Te Nikau, 2123 July 1976.
} 
they were prepared to offer a special leave with "specific defined responsibilities" until the next council in September 1977, but not retain the pastorate. The reason given for denying Worsfold's request to remain in the Wellington pastorate was "to enable other men involved to fulfill council decision." Such phrasing did not make clear the non-negotiable attitude of Pearson, and those who supported his position, towards assuming the responsibility of the Wellington pastorate. ${ }^{60}$

It is not known what motivated Pearson to seek the Wellington assembly. When questioned on this issue 23 years after the event, Pearson thought it was the "done thing" for the president to operate from the capital but could offer no explanation as to why he had wanted the pastorate as well. ${ }^{61}$ In response to a question about local opposition to his taking Charisma Chapel, Pearson said that he "didn't recollect any opposition" and once installed as pastor "didn't feel any conflict." ${ }^{62}$ As president he thought he should be the one to continue in the ministry that the Wellington church had developed towards parliamentarians, diplomats and high-ranking churchmen from the historic churches. ${ }^{63}$ There were many disasters recorded from the reshuffle. Many were profoundly disturbed at the proposed break in the continuity of the work and vision of the assembly, and history has shown that many subsequent unhappy outcomes were attributable, at some level, to the reshuffle. Pearson's time in Wellington ended in sadness: he suffered a major falling-out with Colin Goulton, the pastor appointed to Charisma Chapel when Pearson retired, and felt that his sojourn had not been a success. Pearson believed that the effectiveness of his

\footnotetext{
${ }^{60}$ Minute 1, Extraordinary Council minutes, Te Nikau, 28 October 1976.

${ }^{61}$ It must be remembered that situation surrounding his predecessor, Marcus Goulton, was something of an anomaly in that he did not have a pastorate while president; the usual situation was for the president to also have pastoral responsibility.

${ }^{62}$ W. W. Pearson, phone interview with Luke Worsfold, 23 April 2003.

${ }^{63}$ Rex Meehan recalls asking Pearson at the 1976 Council meeting whether the latter thought he could carry on the ministry to diplomats and parliamentarians then exercised by Worsfold. Pearson replied that he could. Rex Meehan, interview with Luke Worsfold, Wellington, 9 January 2003.
} 
presidency was sabotaged by Worsfold's partial submission to council over the Auckland pastorate, and felt the frustration keenly. ${ }^{64}$

Worsfold acceded to the council and took the responsibility of the Auckland assembly without relocating his family. He flatted alone there while maintaining the family home in Wellington. Every alternate weekend his wife travelled to Auckland to be part of his ministry and on a fortnightly basis he would return to Wellington mid-week. Worsfold accepted several overseas invitations during this time because absence from the country, he reasoned, was a more acceptable explanation for being away from the family home. In his book on the origins of the Apostolic Church, Worsfold makes mention of this episode in a footnote:

Prophetical ministry through prophets often played an important role in arriving at a decision regarding a minister's location. Decisions were finalised by a Council of apostles and were then obligatory. This writer had been part of a national administration which carried out such decisions for thirty years, when he felt that he also should submit to a pastoral change although he had no awareness at all that this was the will of God. The strain and agony of this exercise had calamitous physical consequences on this writer and was the last forced removal of a senior minister in the AC in NZ from one pastoral responsibility to another. ${ }^{65}$

Here the phrase "senior minister" refers to the person's standing within the movement not, as in current usage, position of responsibility in an individual assembly. ${ }^{66}$

Worsfold was appointed president at the 1980 council on the basis of prophecy from Frater who years later described the atmosphere after he had

\footnotetext{
${ }^{64}$ Rex Meehan, personal notes from National Council, October 1979.

Twenty-three years after the fact, Pearson believed that there was no effect on his presidency from Worsfold's failure to fully comply with Council direction. This change in viewpoint is not unexpected given that Worsfold's son was the interviewer. Pearson, phone interview, 23 April 2003.

${ }^{65}$ Worsfold, Origins, $67, \mathrm{n} ., 1$.

${ }^{66}$ Worsfold is correct when he states that he was the last senior minister to be forced to relocate; there was at least one other situation subsequently involving the appointment of a relatively junior minister to a place where he did not want to go. During his term of general superintendency, J. C. Douglas applied pressure on Bruce Monk to relocate from Wanganui to Lower Hutt, although the move was effected by personal pressure from Douglas rather than a united persuasion from the Council. Meehan, interview, 9 January 2003.
} 
prophesied as "electric." ${ }^{\text {"7 }}$ Presumably, this is because there existed factions within council; Pearson's preferred choice as successor was Ron Goulton. ${ }^{68}$ It was at this council that the scope of the president's duties were streamlined to remove the administrative tasks. ${ }^{69}$ The growth of the movement and the development of large areas of ministry such as training necessitated this change and so Ron Goulton was appointed general secretary and administrative director to enable this adjustment. ${ }^{70}$ Evangelism was identified as a major endeavour for the 1980s and this council set the target of doubling the national membership within three years. ${ }^{71}$ Worsfold was released by council in 1979 from the Auckland pastorate to return to Wellington, planting the Thorndon congregation early in $1980 .^{72}$

The attitude of the council towards pastoral appointments changed markedly after the forced relocation of Worsfold to Auckland in 1977. Not only was the council unwilling to effect a move but a release of self-determination became apparent. In 1983 Blair Dickie, pastor of the Invercargill assembly, expressed a desire to move to Australia and work with the Apostolic Church there. James Worsfold wrote to him in his capacity as president stating that "you must be the one to find the man to follow you. I do not see the Council in this role but as already mentioned only to bring confirmation or rejection, and I hardly think they will reject the man that you present."73 If the council was now reluctant to intervene in dissuading a pastor from relinquishing a pastorate and equally slow to suggest a replacement, then it was even more reticent to effect

\footnotetext{
${ }^{67}$ Wilfred Frater, phone interview with Luke Worsfold, 13 October 2002.

W. W. Pearson, the outgoing president, had already closed the Council meeting, the issue of appointing the new president being held over for the next meeting, when Frater uttered the brief prophecy: "I would have my servant Worsfold to be the next president." Pearson, phone interview, 23 April 2003.

${ }_{68}^{6}$ Rex Meehan, notes of conversation with James Worsfold, 31 July 1984.

${ }_{70}^{69}$ Minute 19, Council minutes, Te Nikau, 21-24 October 1980.

${ }^{70}$ Minute 11, Council minutes, Te Nikau, 21-24 October 1980. Appointments were limited to two years duration.

${ }_{71}^{71}$ Minute 19, Council minutes Te Nikau, 21-24 October 1980.

${ }^{72}$ Thorndon eventually birthed three other congregations.
} 
a change when a pastor felt a call to an already occupied pulpit. The second scenario is, of course, the more difficult of the two and when subject to human agenda even the authority of prophecy can fail to direct the outcome. Such was the case when the event of Worsfold's forced move resurfaced for another episode, one that was centred on prophecy. The issue sprang to life again when John Maxwell prophesied at the Ministries Conference in 1983:

I desire that the president will go back to a visible throne for I will cause men of garments . . . they will stand at the courtyard, that they will know this is the house of the Lord, a visible throne in the eyes of the nation where people will ask 'where is your office, where is your throne, where is your help' and you will be able to say 'this is it. ${ }^{74}$

The following year at the February executive, Maxwell prophesied that the president should continue in his role and reiterated the message that he was to ultimately return to Charisma Chapel:

It is my desire that you, my servant Worsfold, return to a visible throne of authority where people will come and meet you, men of dignity, men in government. You establish a throne of authority for you in this city of Wellington. Therefore, it is my desire for you my servant, at the appointed time to return to Charisma again and sit in an office where it will bring dignity to the office of president . . . let there be a visible throne of authority that men can relate to; that men will feel comfortable in the Spirit to come and meet you in the things pertaining to the Spirit . . . there comes a time when you my servant Goulton will be required to relinquish that office, for I have a purpose for you. ${ }^{75}$

This caused major problems for the executive. Firstly, such a move would prove the illegitimate nature of the 1976 decision to remove Worsfold from Charisma Chapel and secondly, the incumbent Colin Goulton had no desire to relocate. Maxwell's prophecy outlined the "purpose" for Colin Goulton relinquishing Charisma Chapel: he was to undertake a missionary journey with his older brother Ron. Apparently, this was not new information for Ron because in the second prophecy the Lord was "reminding" him of the plan.

\footnotetext{
73 James Worsfold, letter to Blair Dickie, 4 October 1983.

74 Hone Maxwell, transcript of prophecy, Ministries Conference, 1983.

${ }^{75}$ Hone Maxwell, transcript of prophecy, Executive meeting, February 1984.
} 
We have earlier discussed the fundamental error in requiring a prophet to explain any part of his utterance rather than asking the Lord for more revelation. Yet this is precisely the course of action taken by Ron Goulton who requested Maxwell to clarify his own prophecy on the issue of the president's return. ${ }^{76}$ Goulton gave Maxwell the "option of not replying and leaving it to the apostleship to interpret" indicating that Goulton was at least aware of the correct procedure. Interestingly, Ron Goulton had no doubt about the instruction to go on a missionary journey with his brother, stating in the memo: "that is not to happen right now."77

Prophecy played a further part in that during a Wellington oversight meeting in July of 1984 a young man with a prophetic function by the name of Paul Stolten prophesied that the Lord was causing a merging in spirit between Worsfold and Colin Goulton and the congregations they pastored, which would serve as a precursor to a "new thing" the Lord would do. ${ }^{78}$ The following week, at a Wellington regional pastors' meeting, Stolten prophesied with more detail calling for the two congregations to come under the leadership of Worsfold who would oversee the planting of new churches in Johnsonville and Mirimar. ${ }^{79}$ Here Stolten was, perhaps unwittingly, revisiting the practice of propheticallyguided church planting once well utilised by the Apostolic Church. While not an ordained prophet he spoke with authority and this level of direction and returnto-Apostolic-roots style of prophecy must have effected the high level of acceptance his word received. The executive, however, saw things differently. Regional superintendent John Douglas was tasked with interviewing Worsfold and Colin Goulton prior to another executive meeting in December that year.

\footnotetext{
${ }^{76}$ Maxwell did respond, prophesying that "the movement will plummet" if the council did not follow the prophetic instruction already given. Hone Maxwell, interview with Luke Worsfold, Wellington, 7 January 2004.

${ }^{77}$ Ron Goulton, memo from general secretary to Executive members, 16 February 1984.

${ }^{78}$ Paul Stolten, transcript of prophecy, Wellington Oversight meeting, 6 July 1984.

${ }^{79}$ Paul Stolten, transcript of prophecy, Wellington Regional Pastors meeting, 13 July 1984.
} 
Douglas had apparently formulated his opinion before he undertook this exercise, writing in a personal letter that "it seems to be an all out bid to 'steal a church."' A few lines further on his exact meaning is obscured in the poor grammar but the tone of Douglas' preconception is clear:

In short, James [Worsfold] needs a building that suits him for his style of ministry, we have now had him there for some five and a half years and nothing has been done to date from his side to actually plan. Just living in a wish that something will come right or Charisma would come back and now Charisma seems to be the place and prophecy has "confusing the situation" drastically. ${ }^{80}$

Perhaps the greatest indictment on executive members' view of prophecy was expressed in a letter from Rex Meehan, at the time not a functioning executive member, to Ron Goulton. Meehan comments on Paul Stolten, saying he is "not particularly moved or impressed" by his prophecies and airs his surprise that the executive has given consideration to them. He then displays a misunderstanding of prophetic integrity, saying of Stolten that "the boy seems to have a conflict of loyalties by treating Billie [Pearson] as his mentor and cultivating a relationship with James [Worsfold] while still being a member of Colin's assembly. I think he needs to sort out his loyalties." 81

Prior to ratification of the executive's decision by the council, Ron Goulton, in his role as general secretary, sent a memo to all council members outlining the deliberations of the executive. In what is arguably the first recorded occasion of a rejection of prophetic statements on the grounds that they passed through a cultural filter, Maxwell's utterance concerning visibility of the church was discounted. Ron Goulton reasoned, on the basis of historical and tribal awareness amongst Maori, that "visibility is important to the Maori. To the European, in the church, this whole issue does not seem to be very important." From this absurd comment he concluded that "cultural background has

\footnotetext{
80 John Douglas, letter to Rex Meehan, 10 December 1984.

${ }^{81}$ Rex Meehan, letter to Ron Goulton, 7 January 1985.
} 
flavoured the prophetical ministry and some parts must be interpreted in this light."

In relation to Maxwell's second prophecy (which contained direction for Worsfold to return to Charisma Chapel) the memo argued that if the "throne" was to be identified with "pulpit," as Worsfold held it to be, then Charisma Chapel was to always be the pastorate occupied by the president at the time. As the presidential term of office was only two years by this stage, the frequent change of pastor for Charisma Chapel would cause major disruption to the congregation. This was a distinctly uninformed misrepresentation by Goulton and/or the executive of Worsfold's thinking. He did not believe that Charisma Chapel was tied to the presidency; such a notion had forced him to vacate that same pastorate several years previously. Rather, he thought that the president should have the responsibility of a congregation. ${ }^{82}$

In a farcical interpretation the executive attributed a concrete meaning to the word "office" in the prophetic phrase "return to Charisma again and sit in an office where it will bring dignity to the office of president" insisting that Worsfold would be no better off operating "from an office at Charisma than he can and already does from the excellent facilities in his own home." The executive succumbed to preconception, ignoring the elucidation of the second prophecy by the first which spoke of the "men of garments" coming to the "house of the apostolic people whereby they know that this is the house of the Lord in the midst of a nation." It is inconceivable that anyone in the executive should have confused the private dwelling of the president with the Lord's house, let alone identified it as a beacon to the nation. The phrase "apostolic house" was well used during Worsfold's presidency to indicate the movement as a whole.

${ }^{82}$ Personal knowledge. 
The comment in the memo relating to Stolten's prophecy is indicative of the methodological straight-jacket which restricted the church government. The executive drew attention to the prophecy being out of order on account of the topics addressed therein falling out of the assembled group's sphere of influence. Missing the point that a new standard of prophecy was arising, the concern was that the administrative hierarchy was being by-passed. The memo reinforced the need for prophecy to be brought in an environment which actually has the power to enact it. The executive felt sufficiently challenged to record in the memo: "We recognise that we are an Apostolic Church and there must be unity of revelation between Apostles and Prophets." Centralism is in operation here, effectively removing decision-making from those most qualified, viz. the local leaders, while retaining it with position holders in the movement, many of whom would have no knowledge of the local situation. Neither Charisma Chapel nor Thorndon have enjoyed happy outcomes. Not long afterwards Colin Goulton suffered a marriage breakdown, and then in 1999 the congregation, which had been relocated and the building renamed, seceded in a manner contrary to the guidelines applied in such circumstances by the Apostolic Church, effectively closing the assembly altogether for several years. The Thorndon congregation initially flourished after the 1994 retirement of Worsfold, but subsequent internal destabilisation eventually resulted in the closure of the assembly in 2003.

In 1986 John Douglas succeeded Worsfold as leader of the movement ${ }^{83}$, the title changing from "President" to "General Superintendent" reflecting the emphasis shift in government of the church. ${ }^{84}$ There was no prophecy guiding the decision to appoint Douglas, rather a vote took place with six for Douglas,

\footnotetext{
${ }_{83}^{83}$ Minute 6b, Council minutes, Te Nikau, 26-29 May1986.

${ }^{84}$ Minute 6a, Council minutes, Te Nikau, 26-29 May1986.
} 
four for Stan Shaw and one abstention. ${ }^{85}$ Douglas's short term of office saw him focussing on training and, while still principal of Te Nikau, Douglas was appointed as pastor of Charisma Chapel with Colin Goulton as associate. ${ }^{86}$ However, the financial viability of the national Bible school continued to falter with the result that crisis point was reached by the end of his second year of office. If the dismantling process apropos centralism had silenced the prophetic voice, then it had also changed the focus of the council members in choosing a leader. The council was looking for financial solutions and one man seemed to be able to provide them - Ron Goulton. At the annual council of 1988 he was appointed as general superintendent and the position of general secretary was abolished. A deputy general superintendent was appointed, Manuel Renata, who also took the role as chairman of the council. ${ }^{87}$

Goulton, while retrospectively describing the unreasonableness of his work-load when newly appointed to general superintendent, incidentally exposed the failure of the Apostolic Church government to appoint a leader on a spiritual basis. Goulton explained that from the time of his appointment in 1988 he had not been a fulltime general superintendent but rather this role had been in addition to his being general secretary. He states: "Because my job description now included two roles the title General Superintendent was used and the secretary title was dropped." ${ }^{88}$ Clearly, the functions were viewed by the council of the day as conducive to merging. The need for, and Goulton's disposition towards, administrative work resulted in the movement being managed rather than led. Throughout his time as general superintendent he pointed to the administrative burden as thwarting his attempts to lead the

\footnotetext{
${ }^{85}$ Rex Meehan, handwritten notes taken during Council, Te Nikau, 26-29 May1986.

${ }_{87}^{86}$ Minute 4b, Executive minutes, Wellington, 25 June 1987.

${ }^{87}$ Minute 5, Council minutes, Waikanae, 8-12 August 1988.

${ }^{88}$ Ron Goulton, memo to Council members, 22 March 1995.
} 
movement spiritually. ${ }^{89}$ Goulton opted for the role of staff chaplain, encouraging pastors by making personal visits. He did realise the efficacy for apostleprophet ministry as demonstrated by earlier leaders and had thought he could interact with local prophets while visiting various assemblies, but lamented that "this last year has been hopeless and it has not really worked."

The devolution of the presidential spiritual authority to a general secretariat administrative function was not without reaction. Within the council there quickly developed a disregard for communication protocols, members apparently giving advice and offering suggestions to individuals in respect to relocations in a loose and haphazard way. In a memo to executive members, Goulton pointed out the danger of such unrestrained counsel causing pandemonium, stating that "there is some evidence of that happening now." Also taking advantage of the leadership vacuum so created, some pastors identified and commissioned people to be prophets and evangelists while other individuals simply took to themselves the title of "pastor." This prompted a call to operate through the appropriately designated authority channels and for area superintendents to supervise a smaller number of churches. While the rhetoric from the general superintendent was one of governmental release rather than control, the model proposed was, of necessity, a top-down structure with more superintendents who would, amongst other duties, be responsible for communicating spiritual vision from the council. ${ }^{92}$ By this stage centralism had diminished in its influence on the movement, the linking of individual churches occurring via the movement's Bible school, national conference, regional

\footnotetext{
${ }^{89}$ After his first year of office, Goulton lamented that "the continual necessity to keep up with desk work has limited my spiritual effectiveness as General Superintendent." General superintendent's report to Council, 1989.

Five years later at the end of his third two-year term as general superintendent, the complaint was still the same, Goulton declaring that he would "not miss the continuing heavy administrative pressure which has during my whole term prevented me from exercising my spiritual leadership role to its full potential." General superintendent's report to Council, 1995.

${ }_{90}$ Ron Goulton, General Superintendent's report to Council, 1989.

${ }^{91}$ Ron Goulton, memo from General Superintendent to Executive, 6 September 1989.
} 
contact and common mission initiatives. Movement of personnel was still worked out through the national council but in this era it was no longer a unilateral decision.

Restructuring was a recurring theme during Goulton's superintendency, the drive for empowerment of local presbyteries being the central feature. The seat of influence, however, was not the general superintendent but rather the principal of the Bible college, ${ }^{93}$ Philip Underwood, perhaps because he was a successful pastor and good developer of people. While Goulton continued to believe that the movement's strength lay in the regional supervisory structure, he did somewhat accurately predict that the council would eventually become a "fraternal of superintendents" responsible for vision-casting, motivation and policy. ${ }^{94}$

Centralism was dealt another blow when Phil Underwood, as the general superintendent who followed Ron Goulton, initiated the closure of the movement's national training centre, Te Nikau, and relocated operations to Hamilton East Apostolic Church. At the same time, existing Bible schools attached to local assemblies were encouraged to expand and other centres inspired to establish training facilities. While initially the Hamilton East campus handled most of the courses and attracted the bulk of the students, other centres sprang up around the country, the current number of schools now totaling 12.

During the Underwood years (1995-1997) governmental authority was delegated most at the level of regional superintendent although the council still functioned as the gyroscopic centre of the movement, deciding policy, facilitating personnel relocations and still requiring a national levy which, in

\footnotetext{
${ }^{92}$ Ron Goulton, General Superintendent's report to Council, 1990.

${ }^{93}$ Ron Goulton, General Superintendent's report to Council, 1991.

94 Ron Goulton, General Superintendent's report to Council, 1992.
} 
1995, underwent its first reduction to $7 \frac{1}{2}$ percent. Restructuring of the Apostolic Church governmental system had received some attention for several years by this stage but only began in earnest under the leadership of Nick Klinkenberg.

\section{Restructuring The Movement}

Until the late 1990s supervision of pastors was carried out on a geographic basis, with a particular region under the authority of an appointed apostle. Areas, comprised of several regions, were governed by the various apostles of the regions represented. All matters of an administrative nature, including appointment of officers, first passed through the area meeting of apostles and pastors before being referred to the executive or, as appropriate, the finance board for action. Under this system pastors had no choice as to who supervised them, it was purely a function of location. Such an arrangement may have always caused friction but it was not formally aired until Brian Tamaki, operating as an apostle in the Rotorua district, told the executive that he did not want to supervise individuals with whom he had no relationship. ${ }^{95}$

Terry Hunter, an Apostolic pastor in Australia who left the movement there to operate independently, influenced Tamaki and others like him who were seeking to be unencumbered by the restraints of the then current system. Bruce Monk, also affected by Hunter, devoted himself to developing his own network of pastors when he was blocked in his bid to be general superintendent in the early 1990s. Monk's grouping, known as the "Equipper's Network," was built on relationship and it operated in addition to the official supervision provided by the church. Over time the Equipper's Network planted churches,

\footnotetext{
${ }_{95}$ Meehan, interview, 9 January 2003.
} 
held their own conferences and established a training school, endeavours that signaled the beginnings of a separate stream within the movement. The implications for this evolving into another denomination were obvious. These observations did not escape Trevor Wilson, pastor of the central Christchurch assembly, who instigated the formation of several networks across the movement linked to the national leadership structure in an effort to provide an environment where the Equipper's Network would be unlikely to secede from the Apostolic Church. ${ }^{96}$

At the start of his leadership term Klinkenberg wanted to restructure the government of the church, avoiding the mistakes of the past in the process, and so there was opportunity for the leadership to devise an appropriate scheme and "start again." Prominent national figure Bruce Monk had, over time, formed mentoring relationships with several pastors in the movement which set the stage for him to promulgate the notion of relational as opposed to geographical supervisors. This made sense because the limitations of the regional supervision system had been apparent for years. Where relational links between pastors already existed these were formalised, and others not in relationship were offered a list of recommended supervisors to choose from, with the option of applying to the national council if personal preference indicated another. The leadership recognised the need for there to be communication between themselves and these supervisors and appointed network leaders whose function was to relate to a group of supervisors. The network leaders were, in fact, the apostles of the movement and the realisation came that there was a need for this group to be in communication and so emphasis on the council was re-established as a result. ${ }^{97}$

\footnotetext{
${ }^{96}$ Meehan, interview, 9 January 2003.

97 Don Lake, interview with Luke Worsfold, Wellington, 23 December 2002.
} 
As a result, networks replaced the geographical supervisory system and a leadership team replaced the national leader, although the concept of an overall leader was retained in that one of the team is identified as "Apostolic Leader." Members of the National Leadership Team (NLT) head up each network comprised of "movement supervisors" and the pastors mentored by them. Movement supervisors are those pastors who have a supervisor's relationship to at least one other pastor. To qualify for attendance at council meetings, movement supervisors must be responsible for three or more pastors. The NLT functions as the executive of the previous structure. Many movement supervisors are apostles, but it is not clear what constitutes an apostle now, at least in terms of criteria for ordination.

The concept of each pastor relating to a "movement supervisor" has the potential to give rise to streams within the denomination. Supervisors with a particular emphasis attract the allegiance of those who resonate with their philosophy and praxis so creating a network of churches who exhibit the same characteristics. The denomination then becomes an affiliation of churches who no longer share a common distinctive.

The trend of pastors to commit to long-term association with a congregation and see themselves as part of the future of a locale has resulted in a reluctance to consider other appointments, indeed, the current thinking amongst the NLT is to not disturb a successful endeavour. Historically, the maximum power exerted by the national governing body, other than requiring resignation, was to force the relocation of a pastor - a facility used for the last time in 1976. The culture of the movement was that at the four yearly council meetings, that is the quadrennial, every pastorate came up for review and 
relocation was a strong possibility. ${ }^{98}$ This process, while promoting the exercise of divine government, had the additional effect of instilling a reverential fear of the council. In those times insurmountable conflict with the council inevitably meant that the pastor resigned from the movement leaving the congregation intact, but such occurrences were rare. The strengthening of the local pastor's position with respect to his congregation has seen a challenge brought to the absolute authority of the council or its present day equivalent. Pastors who have irreconcilable differences with the council are much more likely to leave the movement and take their congregation with them.

Recognising this threat, the NLT established four guidelines for any senior pastor desiring to leave the movement. In an attempt, no doubt, to counter any mesmerisation of the congregation by its pastor, the 2001 protocol included the requirement for a public discussion with an NLT member present. ${ }^{99}$ That such a document should be created indicates that a certain inevitability existed in the minds of the NLT members over the issue of future secessions. Not only that, a measure of powerlessness pervades, it being apparent that a pastor considering taking his congregation out of the movement could not, in reality, be dissuaded or disciplined.

It is highly probable that the impetus for the guidelines was provided by the surprise secession of the Whakatane assembly, under the leadership of Dick Lewis, to join Brian Tamaki's Destiny Church movement in January 2001. ${ }^{100}$ During his first year as pastor of the Apostolic Church in Whakatane, Lewis successfully reduced the financial debt of the church property incurred during the time of his predecessor but he felt unsupported by the national administration in this and other efforts and later responded to the pastoral

\footnotetext{
${ }^{98}$ The changes were read out in a circular issued to all assemblies and congregations who were to have a change of pastor discovered their future in this manner.

${ }_{99}$ Appendix A, NLT minutes, Rotorua, 25-26 June 2001.
} 
overtures made by Tamaki. ${ }^{101}$ The NLT on the other hand were saddened and perhaps disgruntled that Lewis had failed to consult the Apostolic hierarchy before enacting his decision to secede. National leader at the time, Nick Klinkenberg, described the action as "unethical" and contradicting the values of "partnership" and "accountability" held by the movement. ${ }^{102}$ Clearly, the fact that a pastor, complete with congregation, could "out of the blue" announce his withdrawal from the movement unnerved the Apostolic leadership; it served to highlight the need for strong relational links between pastors and their supervisors. The absence of communication from Lewis prior to his move must have prompted the emphasis on dialogue in the other three guidelines, viz. exchange between the pastor concerned, his supervisor and the NLT.

However, within a month another assembly withdrew from the movement. Matt Renata and his Encounter Life City Church in Petone faxed Nick Klinkenberg announcing that they must respond to the "new direction and dimension God has laid before us." In the fax, Renata conveyed that he and his leaders had taken six months to work through the decision while taking counsel from "other senior ministers in NZ" which indicates that Klinkenberg and the NLT had not been involved in this process. ${ }^{103}$ Here, Renata in nominating divine guidance as the reason for withdrawing from the movement, effectively elevates his decision above criticism or even debate. Characteristically, the language of Pentecostals implies the process of divine revelation influencing human decisions; however, the phrase is often trivialised to the extent that God "gets the blame" for the machinations of men.

\footnotetext{
100 As part of Tamaki's strategy for his movement he closed the Whakatane church, encouraging members to relocate to Tauranga to bolster the Destiny congregation there.

${ }^{101} \mathrm{C}$ M Worsfold relaying comments of Hone Maxwell, interview with Luke Worsfold, Wellington, 10 January 2003.

102 Nick Klinkenberg, memo to pastors and leaders, 30 January 2001.

103 Matt Renata, fax to Nick Klinkenberg, 18 July 2001.
} 
2001 saw the Apostolic Church assess that it was not growing numerically and that a number of its churches were in need of remedial attention. A church health consultant was appointed and movement supervisors encouraged to further establish partnership with those for whom they were responsible. Referring to the assemblies who left the movement that year, Klinkenberg wondered if the restructuring had proceeded at too fast a pace, noting that church growth was greater during the 1980s despite a more restrictive governmental structure. As national leader he aired concern that the priority of evangelism was giving way to factionalism which was becoming associated with membership of the various networks. ${ }^{104}$ The problem had not abated during the following year, the 2002 national council agreeing to emphasise the unity of the Apostolic Church rather than focus on the networks. Given the composition of the NLT, this situation was inevitable: the five NLT members had been previously appointed because they led major networks. Recognising the ramifications of this fragmented allegiance, the 2002 council reaffirmed the positions of the five NLT members but only "on the basis of their senior apostolic roles, rather than because of [sic] their roles as leaders of relational groups or networks." ${ }^{105}$

In bringing the Apostolic Leader's report for 2002 to the council, Monk assessed the movement to be moving forward with the NLT functioning well together. He believed the networking system of accountability and mentoring was working well in places. In this the NLT had taken a passive approach, letting the process develop spontaneously and not forcing individuals to utilise the system. Yet despite this positive atmosphere the movement had declined 7

\footnotetext{
${ }_{104}^{104}$ Nick Klinkenberg, National Leader's report to Council, 2001.

105 Minute 4, Council minutes, Auckland, 2-3 July 2002.
} 
percent over the year, prompting the decision to employ a second church health consultant on a part-time basis. ${ }^{106}$

Writing in the March 2003 issue of Apostolic News, Monk explained that his appointment to the role of Apostolic Leader in 2001 was an opportunity for him to realise a long-held, God-given vision of a movement exhibiting: local autonomy; freedom for links to be established on a relational basis; and a release of apostolic initiatives. He had felt that his first priority on becoming leader was to "position our Movement for growth." Without detailing how it had been achieved, Monk expressed confidence that "we are now well positioned as a Movement. The next phase is to grow in unity around a common purpose." An obvious difficulty for Monk, as a strong proponent of networking, is to balance the potential for fragmentation that exists in this system while generating unity of purpose throughout the movement as a whole. He clearly sees himself as equal to the task: earlier in the same article he referred to a prophecy from an individual outside of the Apostolic Church which indicated that Monk would "bring together all the different factions of our Movement into a place of unity." ${ }^{107}$ A further difficulty for Monk in achieving his goal is his physical location; domiciled in London his awareness of the New Zealand milieu is necessarily second-hand. The council, cognisant of the problem, initially appointed Monk as national leader on the proviso that his position be reviewed after one year. This was done and he was affirmed in his role. ${ }^{108}$

Central to Monk's understanding of the progress of the Apostolic Church is a distinction he makes between "denomination" and "movement." The former he identifies with central government, the latter with autonomous local churches

\footnotetext{
${ }^{106}$ Minute 9, Council minutes, Auckland, 2-3 July 2002.

107 Bruce Monk, Apostolic News (March 2003): 3.

108 Minute 4, Council minutes, Auckland, 2-3 July 2002.
} 
linked via a common cause. ${ }^{109}$ Certainly the shift from centralism to local autonomy has been a positive influence in the church but the two terms do not carry the connotations reflecting particular eras of church government which he suggests. From the earliest days of the Apostolic Church the understanding had been that the church was a movement as demonstrated by the once common catch phrase, "We are a movement not a monument." This was precisely the message conveyed by the superintendent of the Apostolic Church in New Zealand during the 1930s, Alfred Greenway, when he preached at the opening of the Wellington congregation's purpose-built facility "City Temple" in December $1936 .{ }^{110}$ It was common for members to refer to the Apostolic Church as a "movement" and within the church particular groupings incorporated the word in their designation such as, the "Witness Movement" or the "Women's Movement." The primary definition of denomination is "church or religious sect" and movement carries the wider definition of "body of persons with a common object."111 Both are appropriate descriptions of the Apostolic Church and it is not necessary to attribute centralised government to a denomination any more than it is to suppose that a movement is freed from such a system. Monk's usage represents more than just an error in semantics. $\mathrm{He}$ is not just contrasting centralism with local autonomy; rather, he is making room for variety of emphases amongst congregations, those with a common thrust coalescing into networks and ultimately, perhaps, forming a federation comprising streams of churches.

\footnotetext{
${ }^{109}$ The commonality of cause was probably stronger in the early days when the personality of the pastor took a lower profile in the determining the character of a particular congregation.

${ }^{110}$ Worsfold, History, 256.

111 Oxford English Dictionary, $8^{\text {th }}$ edition.
} 


\section{Maori Issues}

The Apostolic Church in New Zealand had always enjoyed a strong acceptance amongst Maori, there always being numerous congregations exhibiting an obvious cultural expression of this people. To facilitate expansion amongst the indigenous people, the Maori Mission Advisory Panel was established, originally operative in the northern district and as such answerable to the northern area apostles and pastors. When it was decided, in October 1965, that the body should instead be answerable to the executive and operate nation-wide the name was changed to the Maori Advisory Committee. ${ }^{112}$ At a later stage the name was simplified to the Maori Board.

Prior to 1981 harmonious relationships between the Maori and Pakeha leaderships had been the norm. In that year an incident occurred which displayed both a now evident desire of Maori to operate under their own protocols and a misjudgement by the church leadership in effecting discipline of a Maori pastor. In August 1981 it came to the attention of the president, James Worsfold, and other executive members that the unmarried pastor in Rotorua, David Te Whare, had established a sexual relationship with a married woman. Te Whare was duly faced with his misdeeds and placed under discipline. In an attempt to protect Te Whare, who was chairman of the Maori Board, the reason for his discipline was revealed only to the Maori pastors, which included members of the Maori Board, and the leadership of the Rotorua assembly but no public announcement was made to any congregation. At the time, Te Whare had been delving into Maoritanga and Worsfold drew a link between this involvement with pagan spirituality and the deception associated with his immoral behaviour. The lack of disclosure enabled Te Whare and his close supporters to effectively cloud the issue, shifting the focus from immorality to

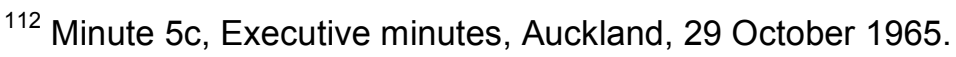


defense of Maori culture. In a deliberate shielding action, Maori pastors who were to inform their presbytery of the reason for Te Whare's discipline failed to do so. Without the full picture many people arrived at an erroneous conclusion, viz. Maori culture was under gratuitous attack.

Worsfold had apparently made some strong comments to Maori Board members concerning their spiritual progress and culturalism, including likening the Meeting House on the marae to a Buddhist Temple. While the analogy has more than a hint of accuracy, and as a seasoned exorcist he was qualified to speak on the origin of spiritual forces, it was a comment delivered to people who were already feeling vulnerable due to their leader, Te Whare, being under threat. Observations on the spiritual climate in Rotorua made by the president to the elders were not, on his instruction, to be conveyed to Te Whare; however, this charge was disregarded with Te Whare receiving the information, which appeared to be used as ammunition in his attacks on the president. Worsfold had instituted a restoration track for Te Whare which included severing contact with the woman involved and avoiding attendance at the church where he had been pastor. Te Whare defied both conditions and on the second count actively moved amongst people to foment dissatisfaction, diverting attention from his failure to the president's negative assessment of elements of Maori culture. However, it was not a clear-cut case of Maori dissatisfaction with Pakeha treatment, for there was a dismissive attitude on the part of Te Whare and his followers towards the Maori Board and those appointed to replace him. Eventually the executive and the Maori Board managed to recoup the situation, although a small group eventually left the Apostolic Church to form an independent fellowship.

To complete the analysis of the situation it is important to note the following observations: 
i. Maori prefer to handle matters concerning their own people themselves and moral failings cause less of a stir than they do in a non-Maori setting. In an environment which was promoting Maoritanga, supporters of $\mathrm{Te}$ Whare would have thought that the situation warranted culturally relevant treatment.

ii. It was a gross error for Worsfold to shield Te Whare from public disclosure of his moral failure because it allowed the latter to redirect attention onto an issue that affected a far greater number of people.

iii. The president's mistake in requiring the Rotorua elders to keep confidence was in overestimating their spiritual integrity; obviously the strength of the human tie-that-binds was stronger.

The consequence of the above is that an unnecessary suspicion of Pakehas developed amongst Maori, expressed in a strengthened desire to selfadminister their affairs. The issue of which elements of Maoritanga were legitimate was almost irrelevant; it was simply a catalyst for the topic of authority. Contextualising the gospel to a particular culture is limited, the outer boundary being the border with syncretism. Determining where that border lies is best done in a secure atmosphere, not one where the missionary targets are feeling threatened or where the counsel is received amidst a masking of sin. While the preoccupation with Maoritanga in the Apostolic Church has waxed and waned since 1981, the drive for self-determination, or at least semiautonomous action, has persisted.

Those involved in championing Maori autonomy in the aftermath of the Rotorua incident were not, apart from Te Whare, central leaders in the Apostolic Church. In contrast, it was the Maori Board the year following which, in a submission to council, stated that they wanted the power to recognise ascension ministries, elect their own board chairman and asserted their prime 
purpose to be one of decision-making and direction-giving, antecedent to submitting such resolutions to the national council. ${ }^{113}$ Clearly, the desire which had been expressed in the context of revolt was now coming through the official channels.

The establishment of the Maori and Pacific Island Council (MPIC) in 1997 was an extension of the Maori Board of earlier years which had served as a sub-committee of the Apostolic Church National Council. However, the MPIC, which was composed of any council member who wanted to identify with things Polynesian, operated without well-defined terms of reference. This led, inevitably, to situations of misunderstanding whereby the MPIC expected equal authority and allocation of funds as the regular council. ${ }^{114}$ While tensions had existed for some time, the catalyst for the show-down between the two councils was the failure of the national body to recognise the ordination to the apostleship of Cecily Pohio, the wife of MPIC Tumuaki, Manu Pohio. The issue might never have reached the status of crisis if the indication for Cecily to become an apostle had not come via prophetic ministry from Tony Faitala, the same prophet who had prophesied the appointment of Bruce Monk as national leader. The argument was obvious; if the national council could accept the word relating to Monk why was there difficulty with the revelation regarding Cecily? The answer lay in the relative levels of authority afforded the two governing bodies. The prophecy concerning Monk came in a national council meeting, whereas the revelation pertaining to Cecily Pohio was uttered at an MPIC. Members of the MPIC then publicly ordained her at a hui in August 2002

\footnotetext{
${ }^{113}$ Ron Goulton, letter to chairman (M. Mete) and secretary (M. Renata) of the Maori Board, 17 August 2002. Goulton wrote to Mete and Renata in his capacity as general secretary to clarify the statements made in the submission ahead of discussion covering the Maori Board at the upcoming Council.

${ }^{114}$ At the time when the MPIC was instituted a proposal was put forward that the Executive have equal representation of Maori and non-Maori members. Although a majority were in favour of such a move, a decision was deferred pending further prayer because the Council were not unanimous on the issue. Minute D, Council minutes, Te Nikau, 15 July \& 17 July 1997.
} 
which drew the response from Monk of suspending Manu Pohio from the NLT and cutting planned input from him and the MPIC to the national conference in October that year. ${ }^{115}$ A letter to the NLT and general council from an unapologetic Manu Pohio explained that his "actions of conviction" resulted from obedience to God; he stated that he was sorry his actions had brought offence. ${ }^{116}$ Monk believed the core issue to be one of "leadership and authority" and so acted decisively. ${ }^{117}$ The NLT met in October, 2002 and, in the absence of Pohio, agreed to dissolve the MPIC. Monk subsequently invited Pohio to take up membership on the NLT again but he declined on the basis that as the MPIC was dissolved there was no point to having his input. ${ }^{118}$

Eighteen years earlier Monk had displayed similar strong tactics when at loggerheads with the board of the Wanganui assembly where he was pastor. Monk deemed that an individual's tithe should be on the gross amount and not the nett whereas the board did not agree and apparently did not apply such a standard to their own giving. On the $11^{\text {th }}$ March 1984 , a notice from Monk in the church bulletin read: "I have found it necessary to dissolve the church board in its present function. This decision has been made after consultation with the church's area superintendent minister, Pastor John Douglas." According to the observations of national executive member at the time, Milton Beatie, the area superintendent simply supported Monk's position, ignored the board's appeal for mediation and failed to respond to their expressed concerns after being sacked. Beattie's assessment was that, if appropriate, Monk would admit to having made a mistake and that reconciliation between Monk and his board was still a possibility. However, Beattie concluded that Monk was unlikely to reconcile if "he is supported in an absolute style of leadership" or in a

\footnotetext{
${ }^{115}$ Bruce Monk, letter to accredited ministers/assembly leaders, 5 September 2002. Confirmed by Don Lake, interview, 23 December 2002.

${ }_{116}$ Manu Pohio, letter to NLT and Council, 23 September 2002.

${ }^{117}$ Bruce Monk, letter, 5 September 2002.
} 
theological stance about which he feels he has divine guidance. ${ }^{119}$ These two episodes indicate that Monk's leadership style has the potential to be detrimental to the well-being of those with whom he disagrees. ${ }^{120}$

With respect to the dissolving of the MPIC, issues highlighted over two decades ago in the Te Whare incident have resurfaced unresolved. The focus of the movement's leaders in that case was to effect restoration to the fallen pastor but his supporters were concerned only with self-determination and cultural expression. The struggle for equality by Maori over the years has caused a frustration culminating, albeit indirectly, in the rogue ordination. ${ }^{121}$ Pohio admits that the MPIC had no mandate to ordain but he feels the action of commissioning Cecily as an apostle was a logical extension of their sphere of authority. He also feels that the current national leader does not want an MPIC. Furthermore, the NLT is perceived as harbouring an attitude towards Maori that "we know what's good for you" and this is seen as the basis for maintenance of the inequality between Maori and Pakeha. ${ }^{122}$ It is possible that the notion of the "Maori mission" has never totally left the movement, militating against establishing equality of government in the movement.

\section{Summary}

The Apostolic Church has, from the outset, sought to exercise divine government through the operation of apostles and prophets. Revelation from

\footnotetext{
${ }_{118}^{118}$ Pohio, interview, 22 April 2003.

${ }_{119}$ Milton Beattie, letter to general secretary, 5 October 1984.

120 It is interesting that in this scenario centralism provided uncritical backing for the pastor when he should have been forced to work it out locally.

${ }^{121}$ It is possible that some personal friction exists between Monk and Pohio in one direction or another. Proceedings at the 1989 Council may have a part to play in this: Pohio was nominated by prophecy to take a place on the Executive, but Monk was nominated by another Council member, a vote falling in favour of Monk eleven to three. Rex Meehan, private notes on Council, Waikanae, 31 July-3 August 1989.

When Klinkenberg retired from the position of national leader, Pohio put his name forward, but this was essentially ignored, the discussion ranging to include possible candidates from outside the movement. Pohio, interview, 22 April 2003.

${ }^{122}$ Pohio, interview, 22 April 2003.
} 
the prophets, and the apostles' actioning of it, could not be coordinated from disparate parts of the country, a centralised administration through a national council being more suitable. This council was therefore concerned with the placement of personnel and the allocation of resources.

In the movement's formative years there was much benefit to be derived from a centralised administration of men and money. The limitations of a financial centralism quickly became apparent, however, to those congregations which grew in size and resources: they contributed far more to the common purse than they used, which benefited the weaker congregations not able to pay their way. Progress was inhibited in these larger assemblies by not having access to their own funds, the rumblings of discontent beginning as early as 1967, and was a major factor in the secession of the influential Lake City Church from the movement in 1994. Financial autonomy came in 1995, although a levy to national office is still in place and is currently set at 5 percent.

The weight attributed to the prophet's input has diminished considerably over the years in direct proportion to the degree of centralised control exercised by the church's governing body, the council. The prophet's role in council was to bring revelation in terms of direction for the movement including placement of personnel. The obvious failure of this system has been the susceptibility of the apostles to succumb to personal agenda and either override a prophecy or move ahead where no prophetic utterance occurred. Absence of prophecy on an issue may sometimes be attributed to a lack in the prophet as opposed to a divine silence. Here the interplay of expectation of the apostleship and ability of the prophets to function is most apparent; there is a direct correlation between the two. The process is best explained in terms of a positive feedback circuit: low expectation on behalf of the apostles leads the prophets to perform to a lower level which in turn lowers the apostles' expectations. It is not possible to 
pinpoint any specific causative factor for the observed decline, but an ongoing catalyst has surely been apostles' management of situations to suit their own designs.

A retarding agent in the progress of the Apostolic Church, which can be directly related to their government, is the frequent mismatch of men and their roles. The insistence that prophets also be pastors has consigned many individuals with a prophetic thrust to a corresponding life in an unsuccessful pastoral role. Similarly, there have been occasions where the chief apostle, i.e. leader of the movement, has possessed no pastoral ability but has displayed other giftings such as evangelism or administration and during such times the movement was not led but rather motivated or managed, respectively. By and large the movement leaders have been men with vision and a measure of graciousness which has enabled them to complete the task. The current leader, Bruce Monk, is an obvious visionary and a strong leader but the passage of time will prove whether he has the diplomacy skills to keep the movement integrated.

Evangelisation of Maori has always been a significant feature of the Apostolic Church. Cultural sensitivity was often achieved with the appointment of Maori pastors to areas with a high indigenous population. Apart from an isolated incident in the early 1980s, syncretism has not been a major issue although the relative importance of events and issues in the Christian life has taken on different proportions for Maori and European church members. One question which has remained unresolved and appears to be growing in importance is the level of authority attached to Maori governance bodies within the church. While the issue has been a live one in the Apostolic Church for a number of years the current atmosphere perhaps reflects Maori selfdetermination evident in the country as a whole. 


\section{CHAPTER SEVEN \\ SYNTHESIS AND PATHWAY FOR THE FUTURE}

\section{Summary: Origins to the Present}

The Apostolic Church distinctive of appealing to the Holy Spirit for divine guidance has provided the environment for the movement to reinterpret its beginnings as a God-inspired outflow of the Welsh Revival. The reluctance on the part of first generation Apostolic Church leaders to recognise the element of human discord that existed between its founders and the mother church created a paradigm where later dissension was subordinated to the theocratic process. This process, mediated by prophecy, permeated all facets of church operation. Not only were decisions made on the strength of prophecy concerning the appointment of personnel, but also on matters of doctrine and the general direction of the church. Prophetic ministry from the office of prophet set apart the Apostolic Church, and the Apostolic Faith Church before them, from other pentecostal groups. The restoration of the apostle and prophet ministries established the Apostolic Church as a vanguard movement, a status which persisted up until the constitution formalised the functions of the church.

The Apostolic Church in New Zealand, as a missionary endeavour of the UK church, was necessarily pioneered by expatriate British personnel; however, it was slow to see New Zealand-born leadership installed at the top level. Centralism, endemic to the UK Apostolic Church, was imported into the New Zealand counterpart, which struggled to free itself from this system for over 50 
years. Restructuring of the movement was begun in the 1980s, a process from which a final product has not fully emerged. A determinant in this is the current understanding of what constitutes an apostle. Of interest here is the influence on the Apostolic Church from the rising new wave of churches, first described (circa 1995) by Ed Delph, pastor of Hosanna Christian Fellowship in San José, as "apostolic" churches. ${ }^{1}$ David Cannistraci has written on this topic and appears to be re-establishing the definition of apostle along the lines exemplified by the life of D. P. Williams, that is, "one who is called and sent by Christ to have the spiritual authority, character, gifts and abilities to successfully reach and establish people in Kingdom truth and order, especially through founding and overseeing local churches." ${ }^{2}$ This definition of apostle, supplied by Cannistraci, hinges on planting and supervising churches. Unfortunately, the Apostolic Church, by its practice, subsequent to the time of Williams redefined the term to be commensurate with "superintendent minister."

Before speculating on the pathway the Apostolic Church may take with regard to apostles and prophets we will first make some comments pertaining to the doctrine of subsequence. ${ }^{3}$ The 1932 prophetic injunction given in the UK that those who are converted "should tarry until they are filled with that power" has lost some of its force over the years. A focus of the Apostolic Church during its first 30 years of existence in New Zealand was establishing the validity of Spirit-baptism in the face of mainstream opposition, a quest in which they found solidarity with other pentecostal groups, viz. the Assemblies of God and the Elim churches. The phenomenon of the Charismatic Renewal saw the

\footnotetext{
${ }^{1}$ C. Peter Wagner, Churchquake (Ventura, CA: Regal Books, 1999), 35, describes how he coined the term "New Apostolic Reformation" based on Ed Delph's 1995 observation.

${ }^{2}$ David Cannistraci, The Gift of Apostle (Ventura, CA: Regal Books, 1996), 29.

${ }^{3}$ While the Apostolic Church itself has not provided an adequate defence of the subsequence doctrine against all points raised by antagonists, pentecostal scholars from other streams have more recently ably demonstrated the viability of the position e.g. Max Turner, The Holy Spirit and Spiritual Gifts: Then and Now (Cumbria: Paternoster, 1996).
} 
acceptance of Spirit-baptism increase markedly, although the experience was not always known by that name in the historic churches where it surfaced. The flip-side to the acceptability of pentecostal experience engendered by the Charismatic Renewal was the teaching against tarrying which followed from charismatic theology; that is, the Spirit is received in water-baptism and later actualised. Therefore, there is no second work of the Spirit and hence tarrying is redundant. We have earlier noted (Chapter Three) that the process of tarrying was effective even if the reason for it was doctrinally unsound. The issue here is the pentecostal doctrine of a second work versus the charismatic notion of actualisation of the already inhering Spirit.

As the need for apologetic treatment of Spirit-baptism has diminished so has the attention given to this doctrine in Apostolic Church ministry training schools. As a result, a spectrum of belief now exists among ministers of the church regarding the status of Spirit-baptism as logically distinct from salvation. The lack of standardisation in teaching in the various congregations has led to a corresponding variation in the depth of experience associated with Spiritbaptism. The likely consequence of this drift will be the loss of pentecostal identification of individual congregations. While this shift towards a style of ministry common to other denominations is not in itself a negative, it does harbour the potential for pentecostal expression to be stifled. If, for example, an Apostolic assembly not overtly pentecostal wanted to develop a pneumatologically-specific ministry such as deliverance, it is possible that there would be a reaction against such a move by the congregation.

A comment from older Apostolic Church members is that current assemblies resemble a Baptist church or that "you wouldn't know it was an Apostolic church." This is borne out by the fact that few people attend an

\footnotetext{
${ }^{4}$ See above, Chapter Two, n. 6.
} 
Apostolic Church on the basis of doctrinal belief. Figuring far more highly on the agenda of those attending is: quality of the music; charisma of the leader; overall ability of the church to meet their needs. Certainly, the profiling of secular counselling in the Apostolic Church lends credence to the observation that the denominational distinctives are fading from pre-eminence, members from yesteryear viewing the utilisation of a christianised psychological counselling model as inferior to prayer, confession or a trip to the altar.

The validity of Spirit-baptism is no longer the issue; the necessity of the experience is now broached in the context of receiving power to be Christ's witnesses, that is, power to reach the lost. This has produced a significant refocus for the Apostolic Church, evangelism taking precedence over preservation of the "Apostolic Vision." While this was a necessary redirection for church growth, the corresponding de-emphasis on Spirit-baptism as an event has created a tendency for a more shallow experience. In this, the contribution from charismatic theology which influenced the movement cannot be underestimated, providing as it did well-written explanations of pentecostal phenomena which deny a subsequent work of the Spirit. A consequence of a superficial encounter in the Spirit is a weaker expression of the gift of prophecy which in turn affects the quality of utterance coming from those recognised in the office of prophet. Theological change has also affected the perception of prophecy: the category shift from "infallible word of God" to "divine-human cooperation" has meant that the function of prophetic words is to inform rather than direct.

This is perhaps a more realistic arrangement given the catalogue of unhappy outcomes endured by Apostolic Church pastors at the hands of council prophets over the years. Yet, if prophecy is again to affect the movement as it 
did in the beginning it needs to develop in specificity, accuracy and authority. Here, two opposing forces interact to produce an equilibrium in the progress of the prophetic within the denomination: it is no longer considered infallible but words of sufficient weight to guide a movement are required.

The structure of the $21^{\text {st }}$ century Apostolic Church will be an integral component in achieving the goal of being a prophetically-inspired movement. Up to the present, a select number of prophets have had a national jurisdiction, being able to prophesy concerning any Apostolic Church assembly or pastor throughout New Zealand. The development of networks within the movement, however, challenged the role of the national prophet; increasingly, network members expected prophetic input to come from within their own particular stream. It is therefore of great significance that the development of networks was de-emphasised over $2003 / 2004$ to the extent that the formal construct of the network hardly featured at all; rather, the exercise of networking was promoted. $^{5}$ That is, simply establishing relationships with other Apostolic Church ministers is more important than belonging to a particular stream within the denomination and adhering to its values. In this way, individual ministers are not constrained by the boundaries of a particular network. This reduced profile of the network as an organisation has meant a corresponding decrease in the potential for development of streams within the movement, which, of course, diminishes the possibility for secession. For instance, the network led by Nick Klinkenberg decided not to hold their own conference in 2004, opting instead to conduct a network-specific session during the annual national pastors' conference. ${ }^{6}$

\footnotetext{
${ }^{5}$ Nick Klinkenberg, phone interview with Luke Worsfold, 11 May 2004.

${ }^{6}$ Don Lake, phone interview with Luke Worsfold, 25 April 2004.
} 
It is worth noting at this point that the internal network system operating in the Apostolic Church is a parallel concept to the external networks of "apostolic" churches which function as organisations linking free-standing churches or even movements by way of affiliation. ${ }^{7}$ These relationship-based structures have apostolic leadership, promote a common vision and purpose, share resources and provide support for its members. The unity of the organisation is maintained through relationship not authority, the constituent members participating in the network on a voluntary basis. The success of a network lies in its ability to do more than maintain each member church in its activity; rather, the development of mission has to be a priority. Frank Damazio, leader of Portland's City Bible Church, highlights the role of mission in the activity of a movement, laying the responsibility for elaborating the mission on its leaders. ${ }^{8}$ John Kelly, overseeing apostle of Antioch Churches and Ministries, lists cooperative mission work as one of the positive features of belonging to his network, ${ }^{9}$ while David Cannistracci identifies a "clear and compelling mission" as indispensable to the continued existence of a network. ${ }^{10}$

A network differs from a denomination in that relationship rather than doctrine forms the strength of the union. Common vision, of course, underlies a close relationship in ministry which is in turn predicated on the expression of one's theology, so doctrine is not irrelevant in binding together the members of a network. However, when difficulties arise within a network it is the relationship-based voluntary submission to the guidance of the apostle which operates rather than enforced submission through the authority structure characteristic of a denomination. For a network to function as more than a

\footnotetext{
${ }^{7}$ See Cannistracci, Gift, ch. 14 and Wagner, Churchquake, ch. 6.

${ }^{8}$ Frank Damazio, The Vanguard Leader (Portland, Oregon: Bible Temple, 1994), 54.

9 John Kelly, "Benefits of Involvement" (informational brochure for Antioch Churches and Ministries, n.d.) quoted in Wagner, Churchquake, 152.
} 
fraternal it must demonstrate several features not dissimilar from that of a denomination. A vision has to be articulated with which the network members can resonate. A major element of the vision needs to address the issue of proliferation or replication of churches and the network must supply the necessary motivation and training to see this effected. ${ }^{11}$

In contradistinction to the relationally-based, geographically unhindered networks, gatherings of pastors on a regional basis are starting to occur in the Apostolic Church. These "clusters," as they are known, are not necessarily run by an apostle and do not take the form of a business meeting with authority to instruct or make decisions but rather seek to foster a fraternal spirit. In this they are distinct from the regional pastors' meetings of earlier times. During 2004 the plan is for the National Leadership Team (NLT) to visit various areas throughout the country and initiate such clusters, providing motivation and imparting spiritual equipment to those in attendance. This is not only reminiscent, but is actually an extension, of the "air-tour" spear-headed by Klinkenberg during his term as national leader. ${ }^{12}$ It seems the NLT, having been faced by the threat of fragmentation due to the networks, ${ }^{13}$ is seeking to re-unify the movement with an appeal to the common bond and input from a centralised leadership. While this may serve to "hold the movement together" it has the potential to place a ceiling on growth and development. Input from a centralised body into the life of a movement tends to stifle, not release, and while New Zealand is not a large country, it is the number of constituents which renders central control of the movement unlikely to succeed. In terms of NLT

\footnotetext{
${ }^{10}$ Cannistracci, Gift, 191.

11 Cannistraci, Gift, 190-194, contrasts relationships with "policies and rules" when describing the difference between networks and denominations. He also lists "elements" and "priorities" of networks, some of which overlap with those mentioned above.

${ }^{12}$ Lake, interview, 25 April 2004.
} 
influence on the denomination there is a move away from governance to leadership. An obvious corollary of this is that decisions may not necessarily be binding ${ }^{14}$ a situation which will preserve the autonomy of the local church. It is axiomatic that leadership is exercised most effectively over those who are able to align themselves with the values of the one leading; therefore, if governance is to be subordinated to leadership, an informal regrouping of personnel into streams of like-minded individuals will inevitably re-occur and networks will have reappeared.

Subsequence, Prophecy \& Structure: Specific Findings

Subsequence is a valid doctrine and forms a necessary component of teaching, both at the congregational and ministry training levels. Its importance lies not in identifying Pentecostals as a distinct theological grouping; rather, it serves as a means to re-establishing the depth of experience that Spirit-baptism offers. Such a revisioning, together with an associated focus on seeker preparation to receive the Spirit, would result in a return to the cataclysmic baptisms experienced by earlier generations of Apostolics. A renewed emphasis on subsequence would counteact the effect of charismatic theology which views Spirit-baptism as an actualisation of what has already been received in salvation. The full spectrum of pentecostal expression would then be more available, bringing missionary power to the church. In particular, a deep Spirit-baptism will ensure a stronger expression of prophecy in those so gifted.

\footnotetext{
${ }^{13}$ Monk confirmed that the existence of networks created an atmosphere of nervousness amongst the movement's leadership regarding the possibility of congregations seceding. Bruce Monk, phone interview with Luke Worsfold, 4 May 2004.

${ }^{14}$ Lake, interview, 25 April 2004.
} 
It has been shown that a reduced expectation of the necessity and quality of prophetic utterance results in a downgrading in the prophet's ability. The expectation of the need for prophecy declined in proportion to the loss of centralised control of the movement. The reduced expectation of receiving quality prophecy influenced the standard of revelation, which is understandable given that prophets tend to perform to a level that is anticipated by the apostolate. Coupled with this is the fact that prophecy is no longer considered $100 \%$ inspired communication, but a divine-human participation. While this is a more realistic view it, too, has helped to effect a reduction in influence of prophecy upon church governance. The following example demonstrates the changes: the denominational thrust toward evangelism in the 1990s relied on strategy not sourced from prophetic input. In stark contrast, the drive of the fledgling Apostolic Church to evangelise the globe was initiated by prophecy.

This study has shown that devaluing prophetic revelation has a concomitant effect on apostolic function. That is, the apostle in pioneering activities to advance the Kingdom, is forced to rely on human initiative in the face of a dearth of prophetic input. Apostolic Church leadership has grown accustomed to making decisions without much prophetic input. With little prophecy occurring, the role of the apostle necessarily changes: the requirement to interpret and execute prophecy is greatly reduced. Currently, prophecy is more likely to be confirmatory rather than directive, further placing the responsibility for the outcome on the apostle. A further ramification of a downturn in the prophetic is the loss of distinction between apostle and prophet: the result is that prophets debate and apostles prophesy.

The relative silence of the prophet at governmental level has been paralleled by a lack of prophetic expression in the public setting, particularly in 
the larger congregations. Accordingly, the practice of exposition on public prophecy has declined, removing an additional avenue of interaction with the prophetic for the would-be hearer of the message. This lack of exposure to prophecy creates an experience vacuum for those in the church who have the potential to develop in the prophetic.

Prophecy failed to help the administration guide the movement through various challenges, particularly the restructuring of the denomination. The role of prophecy and the movement's shape are inextricably linked. If the denomination is centralised then the practice of prophecy will inevitably be likewise. A re-emphasis of the validity of Spirit-baptism as a subsequent experience and the consequent strengthening of the prophetic voice is best expressed in a de-centralised environment. The problem of the prophet speaking from a central committee to individuals with whom he has no relationship would be obviated by his operation within a network of which he was a part. The partial devolution of networks is a retrograde step, moving the denomination towards centralism or at least a centralised input to the newlyformed "clusters."

Ideally the prophet's input within his network would be in the realm of providing guidance for the local church and strategic planning at the regional level including church-planting. It is clear that prophets should interact with apostles who are charged with the responsibility of bringing revelation on the opening up of these new endeavours. A previous focus of prophecy at the governmental level was the relocation of personnel in order to maintain, if not advance, the movement. This study has demonstrated that there were occasions where the revelation brought prophetically either succumbed to personal agenda or simply well-intentioned but ill-conceived direction. 
It is imperative that prophecy not degenerate into simple reminders of wellknown truths or reiteration of Scripture texts if the expression is to have an impact beyond the immediate setting. The possibility exists for well-meaning channels, convinced of the importance of prophecy, to bring low-level revelation or stale messages. This amounts to routinisation where the form of the gift is evident but without significant content. Stimulation of the prophetic gift will occur where it is not only valued but profiled in order to effect change.

The factors which influence the strength of prophecy operate from two origins. On the one side the re-emphasis on subsequence is theological but with an outcome involving praxis. On the other side, the factors which influence do so more from a functional than a theological basis. Factors which fall into this second group include the following: a change in perception of the value of prophecy and the corollary to this, increase in expectation; a prophetic voice which is decentralised; an understanding of prophecy as not $100 \%$ divine; and efforts toward ensuring prophetic expression is not routinised.

The effect of an increase in the strength of prophecy will be to see an increase in apostolic and prophetic function, ideally outworked through a network structure in the movement. If prophetic revelation in a network is endorsed and acted upon with apostolic authority, i.e. through the functioning of an apostle, then there will be Kingdom growth in that situation. Such activity will have a positive flow-on effect for the movement as a whole, even if the effect is felt only in that particular network.

Overall growth in the movement will have an indirect effect on the strength of prophecy in that expansion brings more opportunity for the development of the prophetic. This interaction is represented diagrammatically below: 
The Way Ahead

The way ahead must certainly be to grant more autonomy, not less, to the local church. In 2003 nine congregations left the movement to pursue their own destiny. ${ }^{15}$ Influence from a central source is tantamount to centralised control for any assembly wanting to outwork its mission via an apostolic function. Centralism is difficult to defend biblically and in practice it not only serves to constrain a pastor but paradoxically provides unchallengeable authority from the overseeing apostle when the pastor is faced with discontent in the assembly. On the face of it such a system seems very safe; yet, if a pastor were left to work out his own difficulties with the presbytery then there would be a testing of leadership and, one hopes, a proving. The Apostolic Church could benefit from adopting the Australian Assemblies of God model, best described as a federation style in which each congregation is autonomous. This has, according to David Cartledge, "created movements within the Movement"

\footnotetext{
${ }^{15}$ Lake, interview, 25 April 2004.
} 
allowing the significant growth of the denomination. ${ }^{16}$ Although transformation of the Apostolic Church into a federation of autonomous churches would ensure a commonality of belief, the current trend amongst "apostolic" churches is away from denominational affiliation and into free-standing networks, the leaders of which are in a peer relationship as apostles. Historically, the major practical difference between the Apostolic Church and the Assemblies of God has been the democratic nature of the latter; however, over time the congregational voice has given way to apostolic-type leadership where the pastor provides direction and exercises authority. The freedom for individual assemblies to develop in emphasis and align with mentors of one's choosing have benefited the Assemblies of God movement as a whole.

Living with the possibility of networks within a denomination developing to the point of secession is preferable to trying to maintain the integrity of a movement by constraining the development of various emphases. A stream which so develops, to the point of independence, can be retained in fellowship via the facility of affiliation if alignment under the federation style is considered too restrictive. Secession itself is not a bad thing, providing, as it sometimes does, freedom to promote new revelation or indeed preserve established doctrine.

There are of course points of detraction concerning the development of networks and so to adequately project the pathway for the Apostolic Church we must briefly address these difficulties. The relational factor is an indispensable element in maintaining effective linkage between a pastor and the supervising or mentoring colleague. The current system of pastors selecting their own mentor exhibits the advantages of relationship-based mentoring over the older

\footnotetext{
${ }^{16}$ David Cartledge, The Apostolic Revolution: The Restoration of Apostles and Prophets in the Assemblies of God in Australia (Chester Hill, NSW: Paraclete Institute, 2000), 150.
} 
geographically-assigned regime. Individuals in a network type relationship identify with the vision and ethos of the leader and are therefore more receptive to the prophetic stream expressed in that environment. A potential problem is that with continued increase in the number of affiliates the network assumes the dimension of a denomination and the inherent disadvantages of such are carried forward. As Donald Miller notes, even apostolic networks have the tendency to grow into a centralised bureaucracy which stifles spontaneity. ${ }^{17}$ If the network becomes too unwieldy then an attempt is made to dispense the anointing of the apostle via intermediaries.

An obvious solution would be to generate daughter or sister networks to promote a small mentee to mentor ratio. The key is the number of pastors relating to a given mentor, not how many congregational members are represented: a network of 10 mega-churches may feasibly be handled by one mentor, whereas 20 small-church pastors represents an unworkable ratio. Bearing this in mind, a prophet active in a 10 mega-church network would have ample scope to develop a significant and far-reaching ministry. To guard against the prophet "speaking to order," an opportunity for cross-fertilisation should be created whereby prophets visit other networks to bring input alongside the resident prophets. Ministry to complement the resident prophets is to be preferred over a direct exchange which could create a situation where the unfamiliarity of the prophet causes a valid word to be rejected.

The logical consequence of any network formation within the Apostolic Church is the development of streams or movements within a movement, any one of which has the potential to secede. When this is placed alongside the observation made in 1986 by Apostolic Church President James Worsfold that

\footnotetext{
17 Donald Miller, Reinventing American Protestantism (Berkeley, California: University of California Press, 1997), 181.
} 
proliferation of the charismata across denominations would render the continued existence of the Apostolic Church redundant, it becomes apparent that the formation of an affiliation of autonomous churches from the extant networks is entirely appropriate. Such a move would preserve the integrity of the network, the prophetic revelation flowing within that particular stream maintaining maximum acceptance.

In such a system the topic of prophecy is never going to be relocation of personnel, due to the autonomous stature of the constituents. Rather, prophecy would address issues such as direction and expansion, particularly church planting. When prophets are active in an environment of church-planting rather than a maintenance atmosphere their prophetic activity rises above that of reassurance and reiteration. If the Apostolic Church moves to operating as a national federation of churches it would not be expected that prophecy be routinely directed to all the congregations united under the common banner; any prophecy considered relevant for dissemination to all congregations would therefore be commentary or prediction concerning New Zealand society or world events.

A vital observation for the Apostolic Church is that made by David Cartledge in that prophetic call is insufficient to recognise an apostle; it has to be augmented by judgement "on the merits of their ministry."18 A related thought had been made earlier by Dick Iverson while pastor of Bible Temple in Portland, who said that "being elected to a place of importance is not how spiritual elders are made .. . One qualifies to be a leader by developing relationships." ${ }^{19}$ A significant difference between Apostolic Church apostles and those carrying the title in the current resurgence is the origin of the appointment.

\footnotetext{
${ }^{18}$ Cartledge, Revolution, 220.
} 
The Apostolic Church ordains men to the position, whereas in the new paradigm churches it can simply be the recognition of the status by peers or even a self-appellation.

At this point it is appropriate to attempt to define what constitutes an apostle. Of the 18 characteristics found by Walter Schmithals to distinguish Paul as an apostle, we might agree that: a call by Christ; being a missionary; and demonstrating signs are necessary features of present-day apostleship. ${ }^{20}$ The criteria for apostleship espoused by National Leader Bruce Monk include: influence outside the local church, evidenced by the ability to church plant and the potential to reproduce like ministry; possession of a sign ministry, particularly the supernatural gift of wisdom. ${ }^{21}$ Klinkenberg, the previous National Leader, maintains that apostleship must be related to harvest. Specifically, this means conversions, establishment of new congregations, release of ministry and advancement into new territory. ${ }^{22}$ Clearly the primary activity of the apostle must be to plant churches. Given that in a general sense apostles enact prophecy, revelation which specifically directs to new fields of mission is of particular interest. Apostles act with authority and this may be demonstrated in the realm of establishing the new: not only is the planting of congregations in view here, but the ordination of other candidates for ministry and the impartation of spiritual gifts. Another realm wherein apostolic authority is evidenced is confronting error and opposition; this requires supernatural gifting, most often wisdom and discernment of spirits. Other attributes

\footnotetext{
${ }^{19}$ Christian Equippers International, The Master Builder (1985), 147, quoted in Cannistracci, Gift, 153.

${ }^{20}$ Walter Schmitals, The Office of Apostle in the Early Church, trans. John E. Steely (Nashville: Abingdon Press, 1969), 22-55.

${ }^{21}$ Monk, interview, 4 May 2004.

${ }^{22}$ Klinkenberg, interview, 11 May 2004.
} 
commonly displayed by present-day apostles are gifts of healings, miracles and prophecy. ${ }^{23}$

The concept of apostles functioning on the basis of relationship as opposed to authority necessarily implies that the jurisdiction of an apostle is limited to those with whom he has a personal connection. While this arrangement is admirable when communication is healthy, the effectiveness of the apostle diminishes if the friendship falters or is strained for any reason. In such situations the potential for an individual to remove himself from the covering of his apostle, chosen when relationship was good, and embark on a course of self-authentication is very high. In reference to his Ministers Fellowship International (M.F.I.), Dick Iverson admits that while it is difficult to become a member "it is easy to leave." He attributes the low fall-out rate from his M.F.I. network to relationship, yet this statement belies the rigorous screening that members have passed through to be accepted. ${ }^{24}$ Clearly, there is more to the bond than personal relationship; alignment, which includes doctrine, is a key issue.

${ }^{23}$ Cartledge, Revolution, 289, has a more general outline for apostolic activity, listing the main motivations of an apostle as the drives to:

(i) establish churches or to open up new fields to the Gospel,

(ii) set in order or to build up existing churches,

(iii) open or restore a truth to a church,

(iv) cause breakthrough where the church has settled into traditions or routine religion.

See Cannistracci, Gift, chs. 11 \& 12 and Wagner, Churchquake, ch. 5, who produce their own lists of what constitutes an apostle.

24 Dick Iverson, "Ministers Fellowship International" in The New Apostolic Churches (Ventura, CA: Regal Books, 1998), 177-178. The five steps in the selection process for a pastor applying to join M.F.I. are:

(i) be sponsored by another senior pastor who is already an M.F.I. member who will verify

the applicant's character, gifting and ministry,

(ii) complete a detailed questionnaire on his personal life including domestic, practical and doctrinal issues,

(iii) attend a conference and interact with members,

(iv) interview with members of the Apostolic Leadership Team who use the questionnaire as a basis for discussion,

(v) assessment by the Apostolic Leadership Team of the information gathered at the interview to arrive at a consensus.

Upon acceptance the pastor is introduced at the national conference and awarded a certificate of membership. 
A natural line of authority exists between a pastor and church plants arising from his congregation. In such cases there is generally a pre-existing mentoring relationship between the pastor and the church-planter which transforms into an apostolic oversight function. Problems encountered by fledgling churches are therefore adequately addressed by their "spiritual fathers" who, by virtue of their role in the genesis of the new congregation, have ready-made authority. Where several church-plants relate in such a way to one church, the basis for a network exists.

The need for apostles to inter-relate is fundamental. The possibility for parochialism and error to exist within a network is multiplied if it attempts to function as a closed system. If it is beneficial for the apostle to develop internetwork relationships, then it raises the possibility of networks themselves networking and points to the powerful unity that such a move would generate. ${ }^{25}$ In the Apostolic Church the internal networking system was protected from isolationism in that leaders of the networks were apostles in the movement and as such comprised the church's governing body, the National Leadership Team. The current de-emphasis on networks, however, has placed the focus on the NLT which, paradoxically, is attempting to influence rather than direct. Membership of the NLT is now by appointment of the National Leader, Bruce Monk, a move which further de-profiles network leaders and their apostolic role. The criteria for recognition of an apostle is now even more difficult to measure, borne out by the fact that there has been no ordination to the apostleship for five years.

While the nervousness surrounding the development of networks and their inherent potential for secession is understandable, it is possible that the scope of the apostle has yet to be fully realised by the Apostolic Church. If networks 
were allowed to proceed and the apostles leading them given more freedom, the movement would proliferate, albeit with multiple distinctives. ${ }^{26}$ The effects of a diminished control over the movement by a centralised body are more than compensated for by the advancement inherent in such a move. Possibly the way ahead is to merge the concepts of relationship-based apostleship with the alignment of mind and spirit characteristic of denominational affiliation. The Apostolic Church is not a set of unrelated autonomous local churches looking for a network with which to affiliate; rather, the situation is one of local autonomous denominational congregations needing to regroup into networks where apostleship can function along relational lines. The two scenarios are not equivalent: in the first there is the sense of joining and being part of something larger; in the second there is liberty that comes from following a specific vision. The Apostolic Church, if it is to remain a denomination, will have to allow the development of internal networks at the expense of the power inherent in the governing body, the National Leadership Team, while at the same time promoting a set of common beliefs. ${ }^{27}$ Allowing the networks to administer, discipline and develop themselves will necessarily recognise governance via network-specific prophetic ministry, which is contrary to the current mode of operation. It is important that the recognition of apostleship be a national function and not simply a network initiative, so preserving the unity of the movement. However, the appointment of apostles is necessarily based on their function in the arena of networking.

\footnotetext{
${ }^{25}$ Cannistracci, Gift, 194.

${ }^{26}$ It is interesting that Monk does not see the New Zealand Apostolic Church as a family but as a "group of families." This would point to a preference for networks. Monk, interview, 4 May 2004.

${ }^{27}$ In April 2004, the number of assemblies in the Apostolic Church, NZ stood at 79, down from

100 in 2000. "Directory," Apostolic News 20, no. 4 (2000): 8; \& vol. 24, no. 2 (2004): 12.
} 
The Apostolic Church in New Zealand has outgrown the centralism into which it was birthed. It has moved beyond defence of subsequence to promoting utilisation of the Spirit's power in evangelism. It has sought to release workers into a relationship-based apostleship, a process which has destabilised the authority structure and at the same time removed the potential for spiritual abuse of ministerial personnel. It is clear that there has previously existed a disjunction between core beliefs and their outworking. Those appointed to lead the church did not deliver to the standard implied in the theology of divine government: their behaviour appears no different to dealings characteristic of the secular world. This demonstrates a puzzling gap between theology, faith, and the sociology of the church. Perhaps the theology has expressed a theoretical mechanism of how God works as opposed to the reality.

Certainly the efforts to restructure the movement exhibit a desire on behalf of the leadership to avoid the failures of the past; however, elements of centralist policy currently finding expression will undoubtedly hinder progress. If the denomination can move toward promoting the alignment of autonomous local churches into informal, or even formalised, networks operating within a structure of a national federation of churches, the movement will not fragment but will expand. For this to happen it is apparent that the distinctive upon which the Apostolic Church was founded, viz. divine government of the church, will have to rise to a level where such a direction can be received and enacted. 
APPENDIX

\section{"BAPTISM IN THE SPIRIT" SURVEY}

Please mark the appropriate box with a $\bigotimes$

1. Do you currently believe that baptism in the Spirit is a work of the Spirit subsequent to salvation?

(The doctrine of subsequence allows for baptism in the Spirit to coincide with salvation, but maintains that the two experiences are distinct operations of the Spirit.)

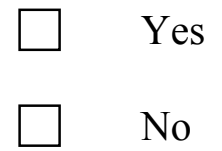

2. Do you currently believe that baptism in the Spirit is an actualisation or appropriation of the Spirit received at either conversion or water-baptism?

$\square \quad$ Yes

$\square \quad$ No

3. Have your views ever changed from, or to, either of the above positions?

$\square \quad$ Yes

$\square \quad$ No 


\section{SOURCES CONSULTED}

Abbott, T. K. A Critical and Exegetical Commentary on the Epistles To The Ephesians And To The Colossians. The International Critical Commentary, edited by S. R. Driver, A. Plummer, C. A. Briggs. Edinburgh: T \& T Clark, 1979.

Apostolic Church Commonwealth Council Minutes of the Great Centenary Convention. Melbourne, October-November 1934.

Apostolic Church Great Britain. Fundamentals. Bradford: Apostolic Publications, n.d.

Apostolic Church New Zealand. Constitution, 1943.

Statistics, 1965.

. Statistics, 1966.

. Statistics, 1967.

Apostolic Church UK. "Report On The England Unity Conference." In the minutes of the Apostolic Church New Zealand Annual Dominion Council Meeting, 21 March 1945, pp. 59-61.

Apostolic Missionary Herald 1, 2 (1927-1928). Bradford, West Yorkshire: Apostolic Church Publications.

Assemblies of God, USA. "Apostles and Prophets." Official Statement by the General Presbytery, 6 August 2001.

Arnold, Allen V. "Could There Be World Tragedy in 1963?" Treasures 7, no. 1 (1963): 14.

. Assembly report for Council. Auckland, 1984.

. "Priorities." Apostolic News (August 1996): 5.

. Letter to W. L. Worsfold, 25 June 1997.

Auber, Harriet. "Our Blest Redeemer, Ere He Breathed." In Redemption Hymnal, hymn no. 206. London: Elim Publishing House, 1951. 
Auld, A. Graeme. "Prophets through the Looking Glass: Between Writings and Moses." In The Prophets, ed. Philip R. Davies, 22-42. Sheffield: Sheffield Academic Press, 1996.

Aune, David. Prophecy in Early Christianity and the Ancient Mediterranean World. Grand Rapids: Eerdmans, 1983.

“Baptismal Service at Rehoboth.” Riches of Grace 1, no. 8 (1919): 19.

"Baptist Minister Visits Pentecostal Meeting." Treasures of Grace 5, no. 4 (1961): 10.

Bauer, W., W. F Arndt, F .W. Gingrich, and F. W. Danker. A Greek-English Lexicon of the NT. Chicago: University of Chicago Press, 1979.

Baxter, David. Interview with Luke Worsfold, Wellington, 21 August 1996.

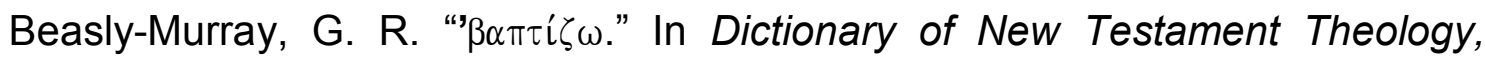
edited by Colin Brown. Exeter: Paternoster, 1975.

Beattie, Milton. Letter to General Secretary, 5 October 1984.

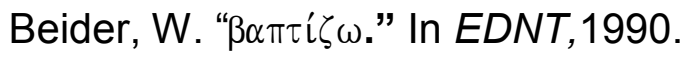

Bendix, Reinhard. Max Weber: An Intellectual Portrait. London: Heinemann, 1960.

Bernard, J. H. John. The International Critical Commentary, edited by S. R. Driver, A. Plummer, C. A. Briggs. Edinburgh: T \& T Clark, 1979.

Bickle, Mike. and M. Sullivant. Growing in the Prophetic. Eastbourne: Kingsway, 1995.

Bidder, W. Correspondence held by James Worsfold.

Blenkinsopp, Joseph. A History of Prophecy in Israel. Louisville: Westminster John Knox Press, 1996.

Blessman, B. "What in the World is God Doing?" Apostolic Life 17, no. 3 (1973): 4-5.

Bloesch, Donald. Life, Ministry and Hope. Vol 2, Essentials of Evangelical Theology. San Francisco: Harper \& Row, 1978.

Blossom, Willis. The Gift of the Holy Spirit, rev. ed. Madison, Wisconsin: n.p., 1925.

Blumhofer, Edith L. Restoring the Faith: The Assemblies of God, Pentecostalism, and American Culture . Urbana and Chicago: University of Illinois Press, 1993. 
Boddy, Alexander A. Excerpt of letter sent to Mr Rowson. Reproduced in Riches of Grace of Grace 15 (December 1962): 382-383.

Boisen, Anton T. "Economic Distress and Religious Experience: A Study of the Holy Rollers." In Collective Behavior, Ralph H. Turner and Lewis M. Killian, 415-420. Englewood Cliffs, N. J.: Prentice-Hall, 1957.

Bongers, F. A. F. Being Conformed to His Image. n.p., 1964.

Boring, Ernest. The Continuing Voice of Jesus. Louisville: Westminster, 1991.

Bredesen, Harald. Testimony in Treasures of Grace 8, no. 1 (1964): 12.

Brown, Francis, Samuel R. Driver, and Charles A. Briggs. Hebrew and English Lexicon. Peabody: Hendrickson, 1979.

Brownlie, J. D. "Apollos And His Converts." Riches of Grace 11, no. 1, special convention number (1935): 110.

"The Promise Of The Father: The Coming Of The Holy Ghost and Fire." Riches of Grace 14, no. 1 (1938): 227.

Bruce, F. F., ed. The First Epistle to the Corinthians. NICNT. Grand Rapids, Michigan: Eerdmans, 1987.

Bruner, Frederick D. A Theology of the Holy Spirit: The Pentecostal Experience and The New Testament Witness. London: Hodder \& Stoughton, 1970.

Burgess, Stanley M. and Gary B. McGee, eds. Dictionary of Pentecostal and Charismatic Movements. Grand Rapids: Zondervan, 1988.

Burrow, A. L. "The Tongues Movement." The Reaper 41, no. 5 (1962): 176-180, 252-255.

Cameron, Murray. D. "Let the Trumpet Sound." Apostolic Life 14, no.1 (1970): 3-5.

Candler, Conor. Transcript of prophecy, Council meeting, 1997.

Cannistraci, David. The Gift of Apostle. Ventura, CA: Regal Books, 1996.

Carroll, Robert P. "Poets not Prophets: A Response to 'Prophets through the Looking Glass."' In The Prophets, ed. Philip R. Davies, 43-49. Sheffield: Sheffield Academic Press, 1996.

Carter, Charles W., ed. A Contemporary Wesleyan Theology. Grand Rapids: Zondervan, Francis Ashbury Press, 1983.

Cartledge, David. The Apostolic Revolution: The Restoration of Apostles and Prophets in the Assemblies of God in Australia. Chester Hill, NSW: Paraclete Institute, 2000. 
Cartledge, Mark. "Charismatic Prophecy: A Definition and Description." JPT 5 (1994): 79-120.

Cathcart, William. "The Coming Age-End Climax." Revival Echoes. (March 1935): 189,192-195.

"Changes in the Scottish Section." Riches of Grace 6, no. 4 (1931): 187-188.

Chapman, J. W. “Holy Spirit, Come In!” In Redemption Songs, hymn no. 837.

Christenson, Larry. The Charismatic Renewal Among Lutherans: A Pastoral and Theological Perspective. Minneapolis: Lutheran Charismatic Renewal Services, 1976.

Christian Equippers International. The Master Builder. 1985, 147. Quoted in David Cannistraci. The Gift of Apostle, 153. Ventura, CA: Regal Books, 1996.

"Christmas Camp Convention." The World and New Zealand 1, no. 1 (1947): 46.

Clarke, lan. Phone interview by C. M. Worsfold on behalf of Luke Worsfold, Wellington, March 2006.

Clements, Craig. Phone interview with Luke Worsfold, 8 October 2002.

Clouse, Robert G. "Rapture of the Church." In Evangelical Dictionary of Theology, ed. Walter A. Elwell. Grand Rapids, Ml: Baker Book House, 1984.

Congar, Yves. I Believe in the Holy Spirit. Translated by David Smith. London: Geoffrey Chapman, 1983.

The Constitution of the Apostolic Faith Church in Great Britain. Bournemouth: Apostolic Faith Church Publications, 1916.

Cousen, Cecil, W., Tegwyn Davies, B. George Evans, T. Kenneth Mitchell, Fred Poole, Benjamin Noot, and Frank Warburton. Excerpts of correspondence to Thomas Turnbull, general secretary, Apostolic Church Executive and General Council, Penygroes, Wales, 1951.

Cousens, C. The Gifts of the Spirit. Eastbourne: Kingsway, 1986.

Cox, Harvey. Fire from Heaven: The Rise of Pentecostal Spirituality and the Reshaping of Religion in the Twenty-first Century. Reading, Massachusetts: Addison-Wesley, 1995.

Crosby, Fanny J. "Here From The World We Turn." In Redemption Hymnal, hymn no. 73. London: Elim Publishing House, 1951.

Cullen, Ivor L. "The Challenge of the Open Door." Apostolic Life 12, no. 4 (1968): 3. 
. Interview with Luke Worsfold, Auckland, 30 September 1996.

Cullen, Lex. "Fourteen Angalu Christians Receive Holy Spirit." Treasures of Grace 9, no. 5 (1965): 12.

Damazio, Frank. The Vanguard Leader. Portland, Oregon: Bible Temple, 1994.

Davies, Philip R., ed. The Prophets. Sheffield: Sheffield Academic Press, 1996.

Davies, R. L. "Members of the New Testament Church." Apostolic Church International Convention, Penygroes, 1962. Riches of Grace 15 (1962): 363-367.

Dayton, Donald W. Theological Roots of Pentecostalism. Metuchen, N.J: The Scarecrow Press, 1987.

Dean, John. Interview with Luke Worsfold, Wellington, 20 January 2003.

Derry, Lewis. Transcript of prophecy, Executive meeting, Fielding, 6-7 July 1965.

. "The Promised Pentecost." Treasures of Grace 11, no. 4 (1967): 3.

. "The Standard of Conduct for Spirit-Filled Christians." Treasures of Grace 12, no. 1 (1968): 8.

. Transcript of prophecy, Council meeting, Wellington, 2-8 \& 16 April 1968. 1971.

Transcript of prophecy, Council meeting, Wellington, 2-4 March

. Transcript of prophecy, Council meeting, Wellington, 29 Feb-2 March 1972.

. Transcript of prophecy, Executive meeting, Wellington, 20-21 June 1972 . 1973.

Transcript of prophecy, Executive meeting, Auckland, 6-8 March

. Transcript of prophecy, Extraordinary Council meeting, Wellington, 29-31 October 1974.

Dickie, Blair. Letter to general secretary, 30 September 1980.

"Directory." Apostolic News 24, no. 2 (2004): 12.

"Directory." Apostolic News 20, no. 4 (2000): 8

Douglas, John. Letter to Rex Meehan, 10 December 1984. 
Dunn, James D. G. Baptism in the Holy Spirit: A Re-examination of the New Testament Teaching on the Gift of the Spirit in Relation to Pentecostalism Today. London: SCM Press, 1970.

. "Baptism in the Spirit: A Response to Pentecostal Scholarship on Luke-Acts." Journal of Pentecostal Theology, no. 3 (1993): 3-27.

Elliger, W. "'€v." In EDNT,1990.

Epiphanius. The Panarion of Epiphanius of Salamis: Books 2 and 3, Sections 47-80, De Fide. Translated by Frank Williams. Leiden: E. J. Brill, 1994.

Erickson, Millard J. Christian Theology. Grand Rapids: Baker Books, 1983.

Ervin, Howard. "I Saw Jesus." Treasures of Grace 8, no. 1 (1964): 10-11.

Evans, Rees. Precious Jewels from the 1904 Revival in Wales. n.p., 1962.

Ewing, Glenn W. "The New Revival in America on the Apostolic Pattern." The World and New Zealand 4, no. 1 (1950): 10. 19. . "Our Lord's Ministry." The World and New Zealand 5, no. 2 (1951):

Eynon, J. D. and Mrs Eynon. "My Experience of the Baptism of the Holy Spirit." The World and New Zealand 7, no. 4 (1952): 10-11.

Farnell, F. David. "Is the Gift of Prophecy for Today?" Bibliotheca Sacra 149/595 (July-September 1992): 277-303; 149/596 (October-December 1992): 387-410; 150/597 (January-March 1993): 62-88; 150/598 (AprilJune 1993): 171-202.

Fee, Gordon D. "Hermeneutics and Historical Precedent--a Major Problem in Pentecostal Hermeneutics." In Perspectives on the New Pentecostalism, ed. Russell P. Spittler,121-126. Grand Rapids, Ml: Baker Book House, 1976.

"Baptism in the Holy Spirit: The Issue of Separability and Subsequence." Pneuma 7, no. 2 (1985): 87-99.

Gospel and Spirit: Issues in New Testament Hermeneutics. Peabody, MA: Hendrickson, 1991.

. God's Empowering Presence: The Holy Spirit in the Letters of Paul. Peabody, MA: Hedrickson/Carlisle: Paternoster, 1994.

Frater, Wilfred. Transcript of prophecy, Executive meeting, 9-11 July 1968. 1969.

Transcript of prophecy, Executive meeting, Auckland, 28-31 October 
. Transcript of prophecy, Executive meeting, Wellington, 25-26 \& 28 February 1972.

. Transcript of prophecy, Council meeting, Wellington, 29 February \& 1-2 March 1972.

.Transcript of prophecy, induction service of J. E. Worsfold as President, Te Nikau, 22 October 1980.

Phone interview with Luke Worsfold, 13 October 2002.

Phone interview with Luke Worsfold, 10 January 2003.

Freedman, David Noel. "Between God and Man: Prophets in Ancient Israel." In

Prophecy and Prophets: The Diversity of Contemporary Issues in

Scholarship, ed. Yehoshua Gitay, 61-64. Atlanta: Scholars Press, 1997.

Freeman, Hobart. An Introduction to the Old Testament Prophets. Chicago: Moody Press, 1968.

Galletly, Peter. Transcript of prophecy, Council meeting, Wellington, 19-21 March 1974.

Gardiner, Alex. Letter to W. W. Pickles, 14 April 1950. Reproduced in the minutes of the Biennial Dominion Council meeting, Wellington, 11-13 April 1950.

. Cover letter to the minutes of the Dominion Council, Wellington, Easter 1951. (1973): 22.

"Present-Day Fulfilment of Bible Prophecy." Apostolic Life 17, no. 3

Gay, A. E. "The Coming Collapse." Revival Echoes (November 1935): 114-115.

Gerlach, Luther P. and Virginia H. Hine. People, Power, Change: Movements of Social Transformation. Indianapolis: Bobbs-Merrill, 1970.

Gitay, Yehoshua, ed. Prophecy and Prophets: The Diversity of Contemporary Issues in Scholarship. Atlanta: Scholars Press, 1997.

Gordon, A. J. The Ministry of the Spirit. Grand Rapids, MI: Zondervan, 1949.

Goulton, Mark, and Ivy Goulton. "My Testimony and Mine." The World and New Zealand 8, no. 1 (1953): 11.

Goulton, Ron. Letter to chairman (M. Mete) and secretary (M. Renata) of the Maori Board, 17 August 1982.

. Memo from general secretary to executive members, 28 June 1983. 

1984.

Memo from general secretary to executive members, 16 February . Memo from general secretary to executive members, 2 May 1986. . Letter to Rex Meehan, 19 August 1986.

. Memo from general superintendent to executive, 6 September 1989. . General superintendent's report, Council 1989.

. General superintendent's report, Council 1990.

. General superintendent's report, Council 1991. . General superintendent's report, Council 1992. . General superintendent's report, Council 1995. 1995.

Memo from general superintendent to council participants, 22 March

Grabbe, L. L. Priests, Prophets, Diviners, Sages: A Socio-historical Study of Religious Specialists in Ancient Israel. Valley Forge, PA: Trinity, 1995.

Grant, Paul E. "The Work of the Holy Spirit in the New Hebrides." Treasures of Grace 6, no. 6 (1962): 12-13. . Letter to Luke Worsfold, 15 May 1996.

Gray, L. W. and M. Gray. "We've Proved God for 44 Years." Apostolic Life 13, no. 1 (1969): 15.

Green, Michael. I Believe in The Holy Spirit. London: Hodder and Stoughton, 1975.

Grossman, S. Stewards of God's Grace. Exeter: Paternoster Press, 1981.

Grudem, Wayne. Systematic Theology: An Introduction to Biblical Doctrine. Leicester: IVP, 1994.

Grudem, Wayne. The Gift of Prophecy in the New Testament and Today. Westchester, IL: Crossway Books, 1988.

Guerin, Jack. "Editorial." Apostolic Life 17, no. 2 (1973): 1. . Transcript of prophecy, Council meeting, 1990. . Interview with Luke Worsfold, Waiuru, 24 August 1996. . Transcript of prophecy, Council meeting, 1997. 
Foundations of Our Faith. n.p., n.d.

Gumbel, Nicky and Sandy Millar. Alpha Conference held at Holy Trinity Cathedral, Auckland, 24-25 October 1996.

Haenchen, Ernst. The Acts of the Apostles. Translated by Bernard Noble and Gerald Shinn. Oxford: Blackwell, 1971.

Harper, Michael. Walk in the Spirit. London: Hodder \& Stoughton, 1968.

Hayford, Jack W. Pastors of Promise: Pointing to Character and Hope as the Keys to Fruitful Shepherding. Ventura: Regal Books, 1997.

Hendery, Eric H. Interview with Luke Worsfold, Auckland, 16 November 1995.

Heron, Alasdair. The Holy Spirit. Philadelphia: Westminster, 1983.

Hetrick, Neil. Phone interview by C. M. Worsfold on behalf of Luke Worsfold, Wellington, March 2006.

Hewitt, John W. J. "Beginnings." Australian Impact (March 2002): 5.

Hewitt, Stan. Phone interview by C. M. Worsfold on behalf of Luke Worsfold, Wellington, March 2006.

Hill, Clifford. Prophecy Past and Present. Crowborough: Highland Books, 1989.

Hoekema, Anthony A. Holy Spirit Baptism. Exeter: The Paternoster Press, 1972.

Holdcroft, Leslie Thomas. The Holy Spirit: A Pentecostal Interpretation. Springfield, MO: Gospel Publishing House, 1962.

. The Holy Spirit. Springfield, MO: Gospel Publishing House, 1979.

Hollenweger, Walter J. The Pentecostals: The Charismatic Movement in the Churches. Minneapolis: Augsburg, 1972.

"The Holy Spirits' [sic] Coming and the Overflow." The World and New Zealand 8, no. 3 (1953): 2.

Hubbard, D. A. Hosea. Tyndale OT Commentaries. Leicester: IVP, 1989.

Hunt, Stephen J. "Deprivation and Western Pentecostalism Revisited: The Case of 'Classical' Pentecostalism." PentecoStudies 1, no. 1 (2002).

Huggett, Joyce. Listening to God. London: Hodder \& Stoughton, 1986.

Hussey, J. M., ed. The Cambridge Medieval History. Vol. 4, pt. 2. Cambridge: 1967. 
Hutchinson, Mark. "The Canada Fire: Revivalist Links between Canada and Australia." Unpublished work, circa 1994.

Hutchinson-Dennis, Aida. Interview with Luke Worsfold, Bournemouth, August 1989.

Hyatt, Eddie L. 2000 Years of Charismatic Christianity: A 21st Century Look at Church History from a Pentecostal-Charismatic Perspective. Dallas: Hyatt Press, 1998.

“Introducing -." The World and New Zealand 1, no. 1 (1947): 3.

Ireson, C. C. "Truths Relating to the Holy Spirit: The Holy Spirit Baptism." Riches of Grace 16 (May 1963): 136-140.

Iverson, Dick. "Ministers Fellowship International." In The New Apostolic Churches, ed. C. Peter Wagner, 171-183. Ventura, CA: Regal Books, 1998

Jackson, Ray Sr. Letter to Richard Riss, 16 March 1977. Quoted in Richard Riss, Latter Rain: the Latter Rain Movement of 1948 and the MidTwentieth Century Evangelical Awakening, 135-136. Ontario: Honeycomb Visual Productions Ltd, 1987.

James, Stanley. Interview with James Worsfold, 1988.

Jenkins, Lewis. "Divine Power, Divine Ability." Riches of Grace 12, no. 2 (1959): 46.

Jourdain, C. H. "At that Instant I Was 'Certain'. .." The World and New Zealand 8, no. 5 (1953): 6.

Juel, D. Messianic Exegesis. Philadelphia: Fortress, 1988.

Kay, William K. Email to Luke Worsfold, 29 March 2005.

Kay, William K. Prophecy! Nottingham: Lifestream Publications, 1991.

Keane, Jim. Transcript of prophecy, Council meeting, Wellington, 15 February 1967.

Keane, Jim W. and Mrs Keane. "Ye Shall Find Me ... While Ye Are Seeking Me." The World and New Zealand 7, no. 5 (1952): 12.

Kelly, John. "Benefits of Involvement." Informational brochure for Antioch Churches and Ministries. n.d.

Kirton, Brian. Transcript of prophecy, Executive meeting, Auckland, 26-28 October 1971. 
Klausner, J. The Messianic Idea In Israel: From Its Beginning to the Completion of the Mishnah. Translated by W. F. Stinespring. New York: Macmillian, 1955.

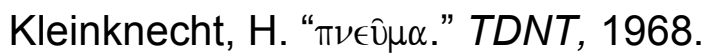

Klinkenberg, Nick. Memo to pastors and leaders, 30 January 2001. . National leader's report to Council, 2001. Phone interview with Luke Worsfold, 11 May 2004.

Knauf-Taylor, Gwen. Phone interview by C. M. Worsfold on behalf of Luke Worsfold, Wellington, March 2006

Knox, Ronald A. Enthusiasm: A Chapter in the History of Religion: A Chapter in the History of Religion. Oxford: Clarendon Press, 1950.

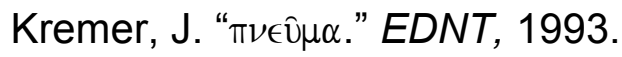

Ladd, George Eldon. A Theology of the New Testament. Grand Rapids: Eerdmans, 1974.

Lake, Donald. Transcript of prophecy, Council meeting, 1990. . Transcript of prophecy, Executive meeting, Auckland, 1-4 May 1995. . Interview with Luke Worsfold, 16 December 1996. . Transcript of prophecy, Council meeting, 1997. . Phone interview with Luke Worsfold, 14 November 2002. . Interview with Luke Worsfold, Wellington, 23 December 2002.

Lederle, Henry I. Treasures Old and New: Interpretations of "Spirit-Baptism" in the Charismatic Renewal Movement. Peabody, MA: Hendrickson, 1988.

Lee, R. G. "Return and Reign of Jesus Christ." Apostolic Life 16, no. 4 (1972): 5.

Lewis, T. Vaughan. "The Baptism Of The Holy Ghost." Riches of Grace 14, no. 1 (1938): 80. Interview with James Worsfold, Palmerston North, 1951. . "My Testimony." The World and New Zealand 8, no. 3 (1953): 4.

Longstaff-Wright, R. "What Is the Baptism In the Holy Spirit?" Herald of Grace 12, no. 3 (1952): 50. 
McBain, D. Eyes That See. Basingstoke: Marshall Pickering, 1981.

McCabe, Joshua. "The Baptism of the Holy Ghost: What Is It All About?" Treasures of Grace 7, no. 3 (1952): 8-10. (1952): 8 .

. "The Evidence of the Baptism" The World and New Zealand 7, no. 4 . "The Baptism of The Holy Spirit: How To Receive Your Baptism." The World and New Zealand 8, no. 1 (1953): 8-10.

. "Speaking in Tongues: The Evidence of the Holy Spirit Baptism." The World and New Zealand 9, no. 5 (1954): 22-26. Taylor.

. "The Spirit-Filled Life." Typewritten article held by Mrs G. Knauf-

McDonnell, Kilian. The Holy Spirit and Power: The Catholic Charismatic Renewal. New York: Doubleday, 1975.

McDonnell, Kilian, ed. Presence, Power, Praise: Documents on the Charismatic Renewal. Vol. 2. Collegeville, MN: Liturgical Press, 1980.

McPhee, John. Letter to T. V. Lewis, Glasgow, 1938. Copy held by James Worsfold.

MacPherson, lan. "Good News for Bad Times." Riches of Grace 1, no. 1 (1985): 3-6. The Faith Once Delivered. Milton Keynes: Word U.K.,1988.

Mallone, G., ed. Those Controversial Gifts. London: Hodder \& Stoughton, 1984.

"The Maori and Pacific Island Council Vision 2001-2004." Apostolic News 21, no. 1 (2001): 5.

Matthews, T. C. "Concerning the Gift of the Holy Spirit." Riches of Grace, no. 6 (1939): 440.

Maxwell, Hone. Transcript of prophecy, Council meeting, Te Nikau, 21-23 November 1983.

. Transcript of prophecy, Ministries Conference, 1983.

. Transcript of prophecy, Executive meeting, February 1984.

. Transcript of prophecy, Council meeting, Te Nikau, 19 May 1986.

. Phone interview with Cecily M. Worsfold, 20 February 2001.

. Phone interview with Luke Worsfold, 12 October 2002. 
Meehan, Rex. Handwritten notes taken during Executive meeting, Wellington, 27-28 July \& 2 August 1971.

. Handwritten notes on his copy of the annual Council agenda, Te Nikau, 21-23 July 1976. 1979 .

. Handwritten notes taken during National Council meeting, October

Handwritten notes taken during Council meeting, 9-12 September 1980 .

. Notes of conversation with James Worsfold, 31 July 1984.

. Letter to Ron Goulton, 7 January 1985.

106.

. "Catching the Next Wave." Riches of Grace 1, no. 7 (1985): 105-

. Handwritten notes taken during Council meeting, Te Nikau, 26-29 May 1986.

. Handwritten notes taken during Council meeting, Waikanae, 31 July3 August 1989.

. Informal report of Executive members meeting with Brian Tamaki, Rotorua, 22 March 1994.

1994 .

Handwritten notes taken during Council meeting, Waikanae, 7 April

. Email to Luke Worsfold, 16 October 1999.

. Interview with Luke Worsfold, Wellington, 9 January 2003.

. Interview with Luke Worsfold, Wellington, 14 January 2003.

. Comment to Luke Worsfold, 6 January 2004.

Menzies, Robert P. Empowered for Witness: The Spirit in Luke-Acts. Journal of Pentecostal Theology Supplement Series, edited by John C. Thomas, Rick D. Moore, Steven J. Land, no. 6. Sheffield: Sheffield Academic Press, 1994.

Miles, Harold. "The Parable of the Ten Virgins." In The Enduring Word: $A$ Report of the Apostolic Church International Convention 5th-13th August 1944.

Miller, Donald. Reinventing American Protestantism. Berkeley, CA: University of California Press, 1997. 
Milne, Bruce. Know the Truth: A Handbook of Christian Belief. Leicester: IVP, 1998.

Monk, Bruce. Letter to accredited ministers/assembly leaders, 5 September 2002.

. "Now." Apostolic News (March 2003): 3.

Monk, Bruce and Ross Forsyth. Letter to Executive, 7 July 1994.

Morgan, C. "How Is The Baptism Of The Holy Spirit Received?" Herald of Grace 12, no. 3 (1952): 64-66.

Morling, G. H. "Pentecostalism." New Zealand Baptist 77, no. 80 (1961): 142144.

Moss, C. B. The Old Catholic Movement: Its Origins And History. Eureka Springs, AZ: Episcopal Book Club, 1977.

Moule, C. D. F. The Holy Spirit. London: Mowbrays, 1978.

Moulton, J. H. Grammar of New Testament Greek, 3d ed. Edinburgh: T. \& T. Clark, 1908.

Muller, Richard A. The Study of Theology: From Biblical Interpretation to Contemporary Formulation. Foundations of Contemporary Interpretation, ed. Moisés Silva, vol. 7. Grand Rapids: Zondervan Publishing House, 1991.

Mumford, Bob. "Flesh or Demons." Reprinted from New Wine (1973) in Apostolic Life 20, no. 1 (1977): 8-11, 22-23.

Murray, Andrew. The Spirit of Christ, rev. ed. Springdale, PA: Whitaker House, 1984.

Neil, William. The Acts of the Apostles. NCBC, edited by Matthew Black. Grand Rapids: Eerdmans, 1973.

Neunheuser, Burkhard. Baptism and Confirmation. Translated by John J. Hughes. Freiburg: Herder, 1964.

Niswander, Dwight E. "An Effectual Door." Treasures 11, no. 3 (1967): 11-12.

Nolland, J. Luke 1-9:20. Word Biblical Commentary. Dallas: Word, 1989.

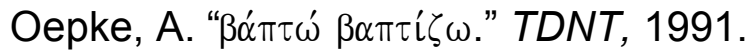

Overholt, Thomas W. Channels of Prophecy: The Social Dynamics of Prophetic Activity. Minneapolis: Fortress Press, 1989. 
. "Prophecy in History: The Social Reality of Intermediation." In The Prophets, ed. Philip R. Davies, 61-84. Sheffield: Sheffield Academic Press, 1996.

Packer, James I. Celebrating the Saving Work of God: The Collected Shorter Writings of J. I. Packer Vol. 1. Carlisle: Paternoster Press, 1998. Keep in Step With the Spirit. Leicester: IVP, 1984.

Pain, Raymond. Interview with Luke Worsfold, Bournemouth, August 1989.

Paloma, Margaret. The Charismatic Movement. Boston: Twayne, 1982.

Parker, Frank. "It's Later Than You Think." Riches of Grace 1, no. 8 (1985): 120-121.

Parry, David. This Promise Is for You: Spiritual Renewal and the Charismatic Movement. London: Darton, Longman \& Todd, 1977.

Pearlman, Myer. Knowing the Doctrines of the Bible. Springfield, MO: Gospel Publishing House, 1937.

Pearson, William W. "A Pertinent Question: Do We Possess the Answers?" Apostolic Life 15, nos. 1-2 (1971): 6-8. . Telephone interview with Luke Worsfold, 23 April 2003.

"The Pentecostal Promise (The filling of the Spirit)." Riches of Grace 13, no.6 (1960): 179-180.

Peters, John. Testimony in Treasures of Grace 8, no. 1 (1964): 12.

Peterson, David L. "Rethinking the Nature of Prophetic Literature." In Prophecy and Prophets: The Diversity of Contemporary Issues in Scholarship, ed. Yehoshua Gitay, 25. Atlanta: Scholars Press, 1997.

Philo De Migratione Abrahami. Trans. F. H. Colson and G. H. Whitaker. London: Heinemann, 1958.

Pickles, W. W. Letter to Alex Gardiner, 17 April 1950. Reproduced in the minutes of the Biennial Dominion Council meeting, Wellington, 11-13 April 1950.

Plato Euthydemus. Translated by W. R. M. Lamb. London: Heinemann, 1962.

Pohio, Manu. Letter to NLT and Council, 23 September 2002. . Phone interview with Luke Worsfold, 7 October 2002. Phone interview with Luke Worsfold, 22 April 2003.

Powell, P. "Holy Spirit Leadership and Christian Renewal." Riches of Grace 4, no. 3 (1980): 41. 
Price, Anna Jean. "As It Was in the Beginning (Acts 2-4) Is Now?" Treasures of Grace 6, no. 5 (1962): 9.

Proceedings of the $15^{\text {th }}$ Synod of the Diocese of Wellington, 1900. Quoted in James Worsfold, A History of the Charismatic Movements in New Zealand: Including a Pentecostal Perspective and a Breviate of the Catholic Apostolic Church in Great Britain, 68-69. Wellington: Julian Literature Trust, 1974.

Purnell, Jacob. "God's Perfect Gifts." Riches of Grace 6, no. 6 (1931): 245-246.

The Qumran Scrolls. I QS 8:16. Zadokite 2:12.

Rayner, Pauline Anne. "Social Characteristics of Pentecostalism: a Sociological Study of the Christchurch Apostolic Church." MA thesis, University of Canterbury, 1980.

Rea, John, ed. Layman's Commentary on the Holy Spirit: A Complete Analysis of the Person and Work of the Holy Spirit from Matthew to Revelation. Plainfield, NJ: Logos International, 1972.

Reah, H. M. "Holiness and Power." Treasures of Grace 7, no. 6 (1963): 10-11.

Reed, G. A. "Pentecostal Truths 322." Mimeographed notes to a course taught at Central Bible Institute, Springfield, MO, 1952-54.

Rees, A. J. Letter to Ron Goulton, 2 June 1981.

Renata, Matt. Fax to Nick Klinkenberg, 18 July 2001.

Rennie, David Taylor. "The Baptism in the Holy Spirit." In Floods upon the Dry Ground: Being a Report of the Apostolic Church International Convention, Penygroes, 5-13 August 1939, pp. 46-48. Bradford: Apostolic Church Publications, n.d.

. "Our Heritage Pentecostal." Riches of Grace 12, no. 2 (1959): 54. Reprinted in Riches of Grace 1, no. 3 (1977): 47-48.

Gifts of the Holy Spirit. Bradford: Puritan Press, 1967.

Revival Echoes: The Official Organ of the Apostolic Church Assemblies in Australasia. 1, 2 (1933-1935). Edited by William Cathcart and Alex Gardiner. Melbourne: Apostolic Church Publications.

Richards, Allen. "The Twin Ministry of Apostles \& Prophets." Riches 1, no. 8. (1985): 123.

Riches of Grace (1916-the present). Originally edited by Daniel Powell Williams. Penygroes: Apostolic Church Publications. Subsequently published by Bradford, West Yorkshire: The Puritan Press. Renamed AC 
Network (2003), accessible on-line at www.apostolicchurch.org/acnetwork.pdf

Riggs, R.H. The Spirit Himself. Springfield MO: Gospel Publishing House, 1949.

Riss, Richard M. Latter Rain: the Latter Rain Movement of 1948 and the MidTwentieth Century Evangelical Awakening. Ontario: Honeycomb Visual Productions Ltd, 1987.

Robeck, Cecil M., ed. Charismatic Experiences in History. Peabody, MA: Hendrickson Publishing, 1985.

Robinson, H. W. "Hebrew Psychology." In The People and the Book, ed. A. S. Peake. Oxford: Clarendon, 1925.

Roman Catholic Word of God Community. The Life in the Spirit Seminars. Ann Arbor, MI: Servant, 1978.

Rosser, C. H. "The Church and Its Mission." Riches of Grace 15 (October 1962): 304-307.

Rowe, William A. C. Quoted in "Voices from the Past." Riches of Grace 15 (October 1962): 310-312.

. One Lord, One Faith. Bradford: Puritan, n.d.

. The Pattern of Pentecost. n.p., n.d.

Ruthven, Jon. On the Cessation of the Charismata: The Protestant Polemic on Postbiblical Miracles. Sheffield: Sheffield Academic Press, 1993.

. "The 'Foundational Gifts' of Ephesians 2:20." Journal of Pentecostal Theology 10/2 (2002):28-43.

Sandbrook, Cyril G. "My Spiritual Pilgrimage and Recent Encounter with the Holy Spirit." Treasures of Grace 10, no. 6 (1966): 12-13.

Scadden, Cecil Charles Haddon. "The Spirit of Christ and the Holy Spirit." Biblestudy notes supplied by Mrs G. Knauf Taylor.

Schmitals, Walter. The Office of Apostle in the Early Church. Translated by John E. Steely. Nashville: Abingdon Press, 1969.

Scofield, Cyrus I. Plain Papers on the Holy Spirit. New York: Fleming H. Revell, 1899.

Shelton, James B. Mighty in Word and Deed: The Role of the Holy Spirit in Luke-Acts. Peabody, MA: Hendrickson, 1991.

Shelton, Raymond. "The Great Psychiatrist." Trinity (1963). Abridged in Treasures of Grace 8, no. 3 (1964): 5-6. 
Showers of Blessing, nos. 1-24 (1910-1918). Edited by William Oliver Hutchinson. Bournemouth: Apostolic Faith Church. Copies supplied by The British Library Reference Division, Reprographic Section, Gt. Russell St., London.

Smedes, Lewis B. "Hope: The Power, The Pain, And The Passion." Fuller Focus 4, no. 2 (1995): 10.

Stark, Werner. The Sociology of Religion: A Study of Christendom. 5 volumes. New York: Fordham University Press, 1966-1972.

Stiles, J. E. The Gift of the Holy Spirit. Burbank, CA: n.p., 1963.

Stolten, Paul. Transcript of prophecy, Wellington Oversight Meeting, 6 July 1984. July 1984.

Stronstad, Roger. The Charismatic Theology of St Luke. Peabody, MA: Hendrickson, 1984.

Sutherland, Iris. World and New Zealand 5, no. 1 (1951): back cover.

Synan, Harold Vinson. The Holiness-Pentecostal Movement in the United States. Grand Rapids: Eerdmans, 1971.

. The Old-Time Power: A History of the Pentecostal-Holiness Church. Franklin Springs, Georgia: Advocate Press, 1973.

. "International Pentecostal Holiness Church." In The Dictionary of Pentecostal and Charismatic Movements, ed. Stanley M. Burgess and Gary B. McGee. Grand Rapids, MI: Zondervan, 1988.

Tate, M. E. Psalms 51-100. Word Biblical Commentary. Dallas: Word, 1990.

Thiessen, Henry Clarence. Lectures in Systematic Theology. Rev. ed, Vernon D. Doerksen. Grand Rapids: Eerdmans, 1979.

Thirkell, Damaris E. To Luke Worsfold, 26 October 1996.

Thomas, Meurig, and Arwyn Davis. Interview with Luke Worsfold, Penygroes, 1989.

Torrey, Reuben Archer. What the Bible Teaches. Basingstoke, Hants: Marshall Morgan and Scott, 1957.

Tosefta of the Talmudic Treatise Sota 13:2.

Tugwell, Simon. Did You Receive the Spirit? London: Darton, Longman \& Todd, 1972. 
"Reflections on the Pentecostal Doctrine of 'Baptism in the Holy Spirit' 2." Heythrop Journal 13, no. 4 (1972): 406.

Turnbull, Thomas Napier. Transcript of prophecy, 8 August 1939. Recorded in Floods upon the Dry Ground: Being a Report of the Apostolic Church International Convention, Penygroes, 5-13 August 1939. Bradford: Apostolic Church Publications, n.d.

. The Full Gospel. Manchester: Puritan Press, 1949.

. What God Hath Wrought: A Short History of the Apostolic Church. Bradford: Puritan Press, 1959.

. "The Deity and Personality of The Holy Spirit: The Preparation and Expectation of The Holy Spirit." Riches of Grace 14 (March 1961): 91.

. "The Deity and Personality of The Holy Spirit: The Holy Spirit and The Body of Christ." Riches of Grace 14 (July 1961): 219.

. Brothers. Bradford: Puritan Press, 1963.

. "Christ's Mystical Body." Riches of Grace 16 (May 1963): 145.

. The Gifts in Corinthians." Series in Riches of Grace 16 (Jan, May, June, Oct 1963).

. Apostle Andrew. Bradford: Puritan Press, 1965.

. Prophecy in the Church Age. Bradford: Puritan Press, 1971.

Turner, Max. The Holy Spirit and Spiritual Gifts: Then and Now. Carlisle, Cumbria: Paternoster Press, 1996.

Turner, Ralph H. \& Lewis M. Killian. Collective Behavior. Englewood Cliffs, N. J.: Prentice-Hall, 1957.

Underwood, Philip. Phone interview with Luke Worsfold, Auckland, 7 November 1996.

"A Valid Pentecostal Experience." Riches of Grace 7, no. 5 (1983): 67-69.

Virgo, Terry. Restoration in the Church. Eastbourne: Kingsway, 1985.

Wagner, C. Peter. Churchquake. Ventura, CA: Regal Books, 1999.

Walker, Andrew. Restoring the Kingdom. London: Hodder \& Stoughton, 1985.

Warburton, Frank. "The Church of Christ." A sermon delivered to the annual convention, Penygroes 1937. Published in Riches of Grace 13, no. 1 (1937): 197-207. 
Wead, Doug. Father McCarthy Smokes a Pipe and Speaks in Tongues. Dallas TX: Wisdom House Publishing Co., 1972.

Weber, Max. Max Weber: Essays in Sociology. Edited by H. Gerth and C. Mills. New York: Oxford University Press, 1946. . Sociology of Religion. Boston: Beacon Press, 1963.

. Max Weber on Charisma and Institution Building: Selected Papers. Edited by S. N. Eisenstadt. Chicago: University of Chicago Press, 1968.

Economy and Society: An Outline of Interpretive Sociology. Edited by Guenther Roth and Claus Wittich. Berkeley: California University Press, 1978.

The Protestant Ethic and the Spirit of Capitalism. Translated by Stephen Kalberg. Oxford: Roxbury, 2002.

Weber, Otto. Foundations of Dogmatics. Translated by Darrell L. Guder. Grand Rapids: Eerdmans, 1983.

Weeks, Gordon. Chapter 32 - Part of: A History of the Apostolic Church 19002000. Barnsley: by the author, 2003.

Wessels, Roland Heinrich. "The Doctine of the Baptism in the Holy Spirit Among the Assemblies of God." Th.D. thesis, Berkley: Pacific School of Religion, 1966.

. "How is Baptism in the Holy Spirit to be Distinguished from Receiving the Spirit at Conversion? A Problem Question for the Assemblies of God." Address given to the annual meeting of the Society for Pentecostal Studies, 1990.

White, G. D. "God Made Me Eat My Words." The World and New Zealand 7, no. 6 (1952): 3-4.

White, Mrs G. D. "In My Own Home." The World and New Zealand 7, no. 6 (1952): 4.

White, Kent. The Word of God Coming Again. Winton, Bournemouth: Apostolic Faith Church, 1919.

White, N. W. "Last Day Sign Ministry." Treasures of Grace 5, no. 4 (1961): 9.

White, Ray. Transcript of prophecy, Council meeting, 1997.

Wierwille, Victor Paul. Receiving the Holy Spirit Today. Van Wert, $\mathrm{OH}$ : The Way, 1957.

Williams, Daniel Powell. Fundamental Doctrines of the Apostolic Faith Church in Wales. Penygroes: Mercury Press, 1914. 
(1919): 3-6.

"Exposition of the Foregoing Prophecy." Riches of Grace 1, no. 8 . "Editorial." Riches of Grace 4, no 5 (1929): 150-151.

. Prophetical Ministry (or the Voice Gifts) in the Church. The Apostolic Church: Penygroes, 1931.

. "Exposition of an Interpretation of Tongues Given at the Apostolic Church International Convention, Penygroes, 3-11 August 1935." Riches of Grace 11, no. 1 (1935): 83.

308.

. "Human Temples For God." Riches of Grace 13, no. 3 (1938): 305-

ed. Souvenir Exhibiting the Movements of God in the Apostolic Church. Penygroes: Apostolic Church Publications, 1933.

Williams, E. H. "Have Ye Received?" Treasures of Grace 7, no. 4 (1963): 10-11.

Williams, Ernest. Systematic Theology. Vol. 3. Springfield, MO: Gospel Publishing House, 1939.

Williams, J. Rodman. The Gift of the Holy Spirit Today. Plainfield: Logos 1980.

"Baptism in the Holy Spirit." In The Dictionary of Pentecostal and Charismatic Movements, ed. Stanley M. Burgess and Gary B. McGee. Grand Rapids, MI: Zondervan, 1988.

Williams, William Jones. "The Infallible Word of God." Riches of Grace 2, no. 1 (1917): 13.

. "Prophetical Ministry." Riches of Grace 7, no. 6 (1932): 252-261.

Williamson, Hugh G. M. "A Response to A. Graeme Auld." In The Prophets, ed. Philip R. Davies, 50-56. Sheffield: Sheffield Academic Press, 1996.

Wimber, John and Kevin Springer. Power Evangelism: Signs and Wonders Today. London: Hodder \& Stoughton, 1985).

Witherington, Ben, III. Jesus the Seer: The Progress of Prophecy. Peabody, MA: Hendrickson Publishers, 1999.

Wolff, H. W. Hosea: A Commentary on the Book of the Prophet Hosea. Translated by Gary Stansell; edited by Paul Hanson. Philadelphia: Fortress, 1974.

Worsfold, Cecily M. Interview with Luke Worsfold, Auckland, 28 September 1996. 
. Interview with Luke Worsfold, Wellington, 10 January 2003.

To Luke Worsfold, 2 January 2004.

. To Luke Worsfold, 6 January 2004.

Worsfold, James Evans. "Baptists and the Pentecostal Baptism." Treasures of Grace 5, no. 4 (1961): 8.

8.

. "The B. T. I and the Pentecostal Fulness." Treasures 7, no. 1 (1963):

A History of the Charismatic Movements in New Zealand: Including a Pentecostal Perspective and a Breviate of the Catholic Apostolic Church in Great Britain. Wellington, Julian Literature Trust: 1974.

The Catholic and Apostolic Ministry of the Apostle and Prophet: The Paul and Silas Ministry. Paraparaumu, New Zealand: Kataritzo Kommunications, 1981.

. Letter to Blair Dickie, 4 October 1983.

. Transcript of prophecy, Council meeting, August 1984.

. "The Apostle Prophet Function." Apostolic News (August 1986): 2-3.

The Origins of the Apostolic Church in Great Britain: With a Breviate

of Its Early Missionary Endeavour. Wellington: Julian Literature Trust, 1991.

The Reverend Gilbert and Mrs Alice White. The New Zealand Apostolic Pioneer Breviate Series, no. 2. Wellington: Julian Literature Trust, 1995.

Cyclostyled notes entitled "Bible Doctrine with Apostolic Distinctives." Lecture no. 5, 2.

www.parkcitychurch.org.nz/ApoNZ.htm

www.oasis.org.nz/church/

www.apo.org

Yocum, Bruce. Prophecy: Exercising the Prophetic Gifts of the Spirit in the Church Today. Ann Arbor: Servant Books, 1993.

"Ystrad." Riches of Grace 1, no. 1 (1916): 13.

Minutes of the Apostolic Church New Zealand

All Officers' Meeting. City Temple, Wellington, 16 April 1938. 
Bible Training Committee. 30 April \& 28 June 1976.

Central Area Apostles and Pastors Meeting. Fielding, 9 March 1965.

Central Area Apostles and Pastors Meeting. Fielding, 6 September 1965.

Central Area Apostles and Pastors Meeting. Fielding, 28 February 1966.

Central Area Apostles and Pastors Meeting. Palmerston North, 28 September 1971.

Council. October-November 1934.

Council. Wellington, 30 March-2 April 9 \& 12 April 1966.

Council. Wellington, 14-17 February 1967.

Council. Wellington, 2-8 \& 16 April 1968.

Council. Wellington, 29 February \& 1-2 March 1972.

Council. Wellington, 8-12 September 1975.

Council. Wellington, 16-19 March 1976.

Council. Te Nikau, 21-23 July 1976.

Council. Te Nikau, 28 October 1976.

Council. Te Nikau, 28 August -1 September 1978.

Council. 9-12 September 1980.

Council. Te Nikau, 21-24 October 1980.

Council. Te Nikau, 26-29 May1986.

Council. Waikanae, 8-12 August 1988.

Council. Te Nikau, 15 July \& 17 July 1997.

Council. Auckland, 2-3 July 2002.

Dominion Council. Wellington, July 1942.

Dominion Council. Wellington, April 1960.

Executive. Fielding, 6-7 July 1965.

Executive. Auckland, 29 October 1965. 
Executive. Wellington, 31 October \& 4 November 1967.

Executive. Hamilton, 6-7 December 1967.

Executive. Auckland, 28-31 October 1969.

Executive. Wellington, 9-12 November 1970.

Executive. Wellington, 1 March 1971.

Executive. Wellington, 27-28 July \& 2 August 1971.

Executive. Auckland, 26-28 October 1971.

Executive. Wellington, 24 March 1975.

Executive. Wellington, 28 May1975.

Executive. Wellington, 20 May1980.

Executive. Te Nikau, 4-5 November 1986.

Executive. Wellington, 25 June 1987.

Executive. Waikanae, 15-17 August 1994.

Finance Board. Wellington, 12 October 1971.

Finance Board. Wellington, 28 September 1972.

Finance Board. Wellington, 24 July 1973.

Finance Advisory Board. Te Nikau, 25-26 March 1977.

Finance Advisory Board. Te Nikau, 29-30 July 1977.

Missionary Board. Wellington, 13 February 1975.

National Leadership Team. Rotorua, 25-26 June 2001.

Representative Council. Wellington, 12-14 November 1974.

Southern Area Apostles and Pastors Meeting. Dunedin, 2-3 June 1967.

Special Council. Te Nikau, 21-24 February 1978.

Special Meeting. Wellington, 14-15 April 1975.

Wellington Area Apostles and Pastors Meeting. Hastings, 18 September 1950. 